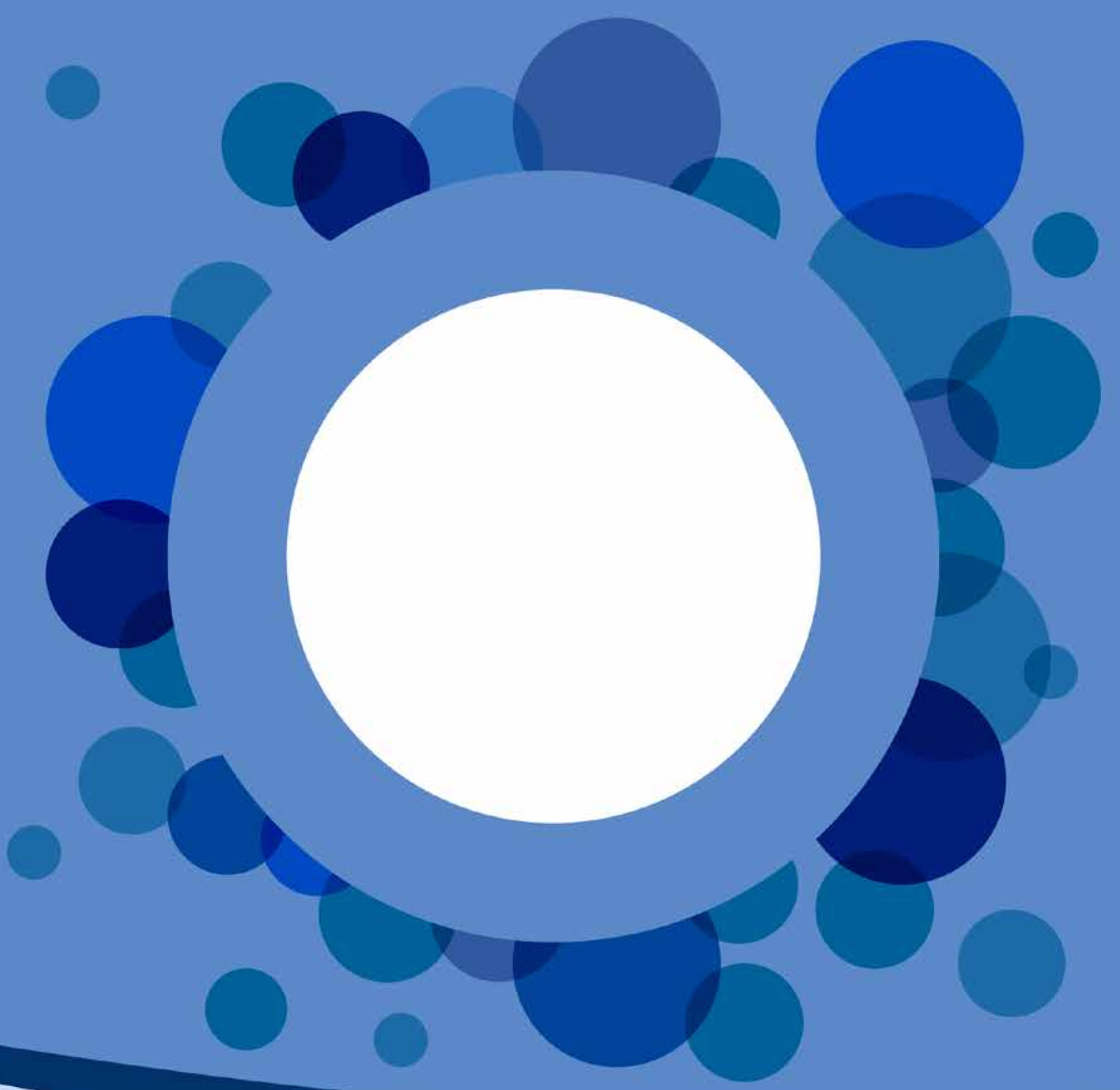

Història i situació actual de l'Educació Terapèutica en Diabetis a Catalunya i el rol de la infermera

Tesi Doctoral

Maite Valverde Torreguitart 2017 



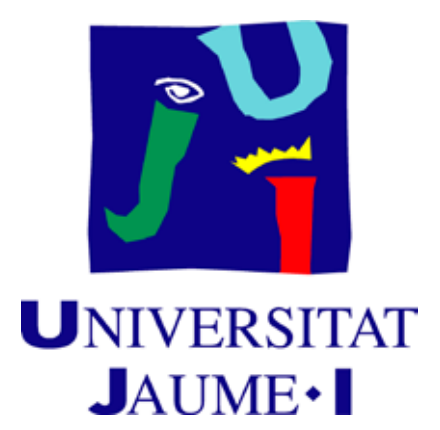

Programa de Doctorat en Ciències de la Salut

\title{
Història i situació actual de l’Educació Terapèutica en Diabetis a Catalunya i el rol de la infermera
}

\author{
Tesi Doctoral \\ Maite Valverde Torreguitart \\ Directors de tesi \\ Dra. Pilar Isla Pera. Universitat de Barcelona \\ Dr. Joaquín Moncho Vasallo. Universitat d’Alacant
}

Juny 2017 

A la meva mare Maria i a les meves filles, Laura i Marta.

«La primera tasca de l'educació és agitar la vida, però deixar-la lliure perquè es desenvolupi». (...) «La millor ensenyança és la que utilitza la menor quantitat de paraules». 
6

$$
6
$$




\section{AGRAIIMENTS}

Els meus agraïments van, en primer lloc, als meus directors de la Tesi, la Dra. Pilar Isla i el Dr Joaquin Moncho. La Pilar va ser la primera persona que em va motivar per fer el Màster en Ciències de la Infermeria que m’ha donat lloc a poder realitzar la Tesi. Ja fa anys que és professora a la Universitat i mai s'ha desvinculat de la diabetis. Durant tot el procés m'ha ajudat i orientat i en els moments que he defallit he pensat en ella, en com ens ha motivat a la Marga i a mi per fer-la. Pilar, mai et podré agraïr tot el que m’has ajudat. Moltes gràciesii

Al Joaquin per la seva amabilitat i paciencia. Gràcies per ajudarme en la tasca per mi més dura com es l'estadística. Moltes gràcies perquè no ho hauria aconseguitii

A la DUI i amiga Margarida Jansà, juntes vam fer el Màster i sense ella crec que no l'hagués acabat. Recordo les hores al telèfon fent els problemes d'estadística i comentant les classes. Va ser un suport constant durant els dos anys que va durar el Màster i també ara ho continua essent. Moltes gràcies Margaii

Al Dr. Jordi Anglada, Cap del Servei d’Endocrinologia i Nutrició de l'Hospital on treballo, pel seu suport i motivació. Ell sempre ha cregut en la importància de l’Educació Terapèutica i ho ha defensat en moments difícils per a la supervivència del nostre Servei. A més, sens dubte, és un gran company. "Està bé això de que vulguis fer la Tesi, a la teva edat", diu sovint. Gràcies Jordi!!

A la meva mare Maria de qui he aprés a estimar la feina i al meu pare, Josep, que per desgràcia fa anys que no és entre nosaltres, però li hagués agradat molt poder assistir a la lectura d'aquesta Tesi.

De manera molt especial, a les meves filles. De vegades $m^{\prime}$ 'he sentit culpable perquè he dedicat tant a la feina que els hi he restat temps. Elles em diuen, mama, si no et "lies" amb coses de la feina no ets feliç.

Gràcies als meu companys de feina, especialment a la Dra. Verónica Perea que s'ha passat moltes estones ajudant-me a entendre aquest difícil mon de l'estadística.

A la Conxi Caro pel seu suport i ajuda en la recerca bibibliográfica i en la correció de les cites. Moltes gràcies, Conxi. 
També a tots els professionals, metges i infermeres que van creure en l'Educació Terapèutica, que es van formar i a la vegada van formar a altres professionals, especialment infermeres els quals alguns d'ells han accedit amablement a ser entrevistats. A tots els companys/es infermers/es, tant els que conec com els que no, que es dediquen a l'Educació Terapèutica a l'assistència primària o a l'especialitzada i que amb les seves respostes han fet posible la realització d'aquesta tesi.

Finalment i no per això menys important, vull agraïr a totes les persones amb diabetis i les seves famílies per que ells han estat la meva motivació principal per anar a treballar cada dia.

Sense tots ells no hagués estat possible fer aquest treball. 


\section{ABREVIACIONS}

AADE: American Association of Diabetes Educators

ABS: Area Bàsica de Salut

ACD: Associació Catalana de Diabetis

ACED: Associació Catalana d'Educadors en Diabetes

ADA: American Diabetes Association

ADE: Asociación de Diabéticos Españoles

AE: Assistència especialitzada

AMGC: Automonitoratge de la glucèmia capil·lar

APDP: Associaçao Protectora dos Diabeticos de Portugal

APS: Atenció Primària de Salut

BC-ADM: Board Certified Advanced Diabetes Manager

CAP: Centre d'Atenció Primària

CDE: Certified Diabetes Educator

CDECB: Canadian Diabetes Education Certification Board

CEIC: Comitè d'Ètica d'Investigació Clínica

$\mathrm{CIE}$ : Consejo Internacional de Enfermería

DCCT: Diabetes Control and Complications Trial

DECS: Secció Consultiva sobre Educació Terapèutica

DESG: Diabetis Education Study Group

DM: Diabetis Mellitus

DM1: Diabetis Mellitus tipus 1

DM2: Diabetis Mellitus tipus 2

DMG: Diabetis Gestacional

DSME/S: Diabetes Self-Management Education and Support

DSME: Diabetes Self-Management Education

EAP: Equip d'Atenció Primària

EASD: European Association for the Study of Diabetes

ENDCUP: Collaborative University Programme

EpS: Educació per la Salut

ET: Educació Terapèutica

ETD: Educació Terapèutica a la Diabetis

EUA: Estats Units d'Amèrica

FEAED: Federación Española de Asociaciones de Educadores en Diabetes

FECADI: Federació Catalana d'Associacions de Diabètics

FEDE: Federación de Diabéticos Españoles

FEND: Foundation of European Nurses in Diabetes

FORCEM: Formació Contínua de les Empreses

FRCV: Factors de Risc Cardiovascular

GBA: Glucosa Basal Alterada

HAS: Haute Autorité de Santé 
HbA1c: Hemoglobina Glucosilada

ICE: Infermera Clínica Especialista

ICS: Institut Català de Salut

IDF: Federació Internacional de Diabetis

IES: Institut d'Estudis de la Salut

IMC: Índex de Massa Corporal

IOG: Intolerància Oral a la Glucosa

IPA: Infermera de Pràctica Avançada

LACRE: Lucha Antidiabética de la Cruz Roja Española

NICE: National Institute for Clinical Excelence

OMS: Organització Mundial de la Salut

ONCE: Organización Nacional de Ciegos de España

PTE: Patient Therapeutic Education

SCD: Societat Catalana de Diabetis

SED: Sociedad Española de Diabetes

TTOG: Test de Tolerància Oral a la Glucosa

UAB: Unitat Bàsica Assistencial

UDEN: Unitat de Diabetis, Endocrinologia i Nutrició

UKPDS: United Kingdom Prospective Diabetes Study 


\section{RESUM}

La diabetis mellitus (DM) és una malaltia crònica, complexa, que requereix atenció mèdica continuada, educació terapèutica (ET) del pacient per a l'autogestió del tractament i suport permanent a fi d'evitar complicacions agudes, reduir el risc de complicacions cròniques i millorar la qualitat de vida. L'ET és un dels pilars fonamentals del tractament de la malaltia, ja que ajuda els pacients a prendre consciència del problema i a adaptar el control de la diabetis a la vida diària. Permet donar el suport necessari tant als pacients com a les famílies per a l'autogestió del tractament.

En la majoria dels països la infermeria és la que lidera el procés educatiu. El treball en equip i la formació dels professionals són essencials per oferir una educació terapèutica de qualitat i obtenir uns millors resultats. Les competències dels professionals han d'estar basades, tal com defensen diferents societats científiques, en aspectes biomèdics, cures culturalment competents al llarg de la vida, habilitats comunicatives i pedagògiques, planificació de programes educatius per a l'autogestió del tractament dirigits a les persones amb diabetis, familiars i cuidadors, organització de l'assistència i el treball en equip, i avaluació de resultats.

En el nostre medi l'assistència primària (AP) és el principal lloc d'atenció de la majoria de malalties cròniques, com la diabetis (DM), específicament la diabetis tipus 2, i es deixa per a l'assistència especialitzada (AE) la diabetis tipus 1 (DM1) i la diabetis tipus 2 (DM2) més evolucionada.

Aquest estudi s'ha dut a terme en l'àmbit territorial de Catalunya i s'ha desenvolupat en dues fases:

\section{Fase 1}

Es va realitzar un estudi qualitatiu, històric i descriptiu amb l'objectiu d'explorar com es va construir l'estructura de les unitats de diabetis i d'educació terapèutica a Catalunya, des dels punts de vista dels professionals que en van ser referents al començament i en el desenvolupament posterior.

Mètode: Es va utilitzar una mostra intencionada de professionals de l'àmbit mèdic, d'infermeria i de l'administració sanitària, els quals van estar implicats de manera activa en el procés d'organització i d'implementació de l'ET a Catalunya, i als quals es va fer una entrevista semiestructurada. També es va dur a terme una revisió històrica de documents corporatius de les associacions de pacients amb diabetis i de professionals, així com de l'hemeroteca de premsa escrita.

Resultats: Es van entrevistar 15 professionals (8 metges i 7 infermeres). Es va identificar que abans dels anys vuitanta: $a$ ) l'educació dels pacients era patrimoni només d'alguns professionals; b) s'utilitzaven mètodes bàsicament unidireccionals, com ara xerrades o conferències; $c$ ) no es tenia en compte la decisió compartida, sinó el compliment de la prescripció facultativa; d) no 
existia la figura de la infermera educadora en diabetis, i $e$ ) el paper de la infermera en el camp de la diabetis fora de l'àmbit hospitalari era poc rellevant.

Als anys vuitanta: I'Hospital de St. Pau i l'Hospital Clínic de Barcelona van ser pioners en la creació d'unitats d'ET, amb programes estructurats impartits per equips multidisciplinaris. Els elements motivadors més importants perquè un col-lectiu ampli de professionals obrís el camp de l'educació en el tractament de la diabetis van ser: $a$ ) la influència dels canvis polítics i socials (trencar normes i buscar noves maneres de fer també en el camp de la medicina), i $b$ ) l'evidència científica que arribava d'altres països (Europa i els EUA).

Els elements que van facilitar la implantació de l'ET a Catalunya a la dècada dels anys vuitanta i noranta van ser: $a$ ) la formació dels professionals a través dels cursos de formació en diabetis del Institut Català de la Salut (IES) i del Consell Assessor sobre la Diabetis a Catalunya; $b$ ) els avenços tecnològics i les experiències europees que venien del Dr. Assal, a Suïssa, o del Dr. Berguer, a Alemanya; c) el suport polític i la Declaració de Saint Vincent, que va marcar les decisions de política sanitària en el camp de la diabetis; $d$ ) la il·lusió i el voluntarisme dels professionals; $e$ ) el paper que van tenir les associacions de pacients i el suport que hi van donar, i $f$ ) la contribució de les associacions de professionals (l'antiga Associació Catalana d'Educadors en Diabetis i l'actual Associació Catalana de Diabetis) en la formació i el desenvolupament de programes i guies clíniques, d'educació terapèutica i d'integració i col·laboració amb les associacions de pacients.

A finals dels anys noranta, arran de la conclusió de la reforma de l'assistència primària es va produir un canvi polític i sanitari que va comportar: $a$ ) que la figura de la infermera educadora de diabetis als centres d'atenció primària (CAP) fos assumida per la infermera generalista; $b$ ) una pèrdua de compromís dels metges amb l'educació; $c$ ) una manca d'iniciativa d'aquells professionals que creien en l'educació, i alhora una manca de lideratge i de metodologia de treball del col-lectiu d'infermeria; $d$ ) que la formació en diabetis i en ET dels professionals deixés de ser prioritària per a l'administració sanitària, i e) que la política de mobilitat dels professionals de la infermeria en els centres no tingués en compte la seva formació.

Conclusions: A Catalunya l'educació terapèutica en diabetis es va començar a desenvolupar als inicis dels anys vuitanta del passat segle.

La formació dels professionals, en especial el «Curs de formació de professorat en educació diabetològica», i el suport polític i institucional van permetre la creació de la figura de l'educador en diabetis dins de les unitats de diabetis dels hospitals, a l'assistència primària no reformada i als CAP II (centres d'atenció especialitzada).

La reforma de l'assistència primària va potenciar que la majoria de persones amb diabetis, especialment de tipus 2 fosin atesses en aquest àmbit deixant en segon terme l'assistència especialitzada. No es considerava la formació en diabetis dels professionals i es va relegar la figura de l'educador en diabetis només als hospitals i a alguns CAP II, model que s'ha mantingut fins a l'actualitat. 


\section{Fase 2}

Es va dur a terme un estudi descriptiu, transversal i comparatiu amb l'objectiu de descriure el grau d'implementació de l'educació terapèutica, així com el nivell de formació específica en diabetis, nutrició i educació terapèutica dels professionals que la imparteixen.

Mètode: La població d'estudi van ser els professionals d'infermeria de l'àmbit de l'assistència especialitzada (tots els professionals dedicats a l'educació terapèutica en diabetis dels hospitals que disposen de servei d'Endocrinologia) i de l'assistència primària. Es van seleccionar tots els centres d'assistència especialitzada que disposaven de servei d'educació en diabetis (46). D'altra banda, es va realitzar un mostreig per conglomerats de totes les Àrees Bàsiques de Salut (ABS) i se'n van seleccionar aleatòriament 97.

Es va adaptar i validar un qüestionari, originàriament en llengua anglesa, a la llengua castellana, que es va enviar a les infermeres dels serveis d'Endocrinologia i Nutrició dels hospitals i a les ABS seleccionades, previ contacte amb les direccions d'infermeria corresponents.

Resultats: Es van analitzar els qüestionaris de 287 professionals d'infermeria. El 24,3 \% treballaven a l'assistència especialitzada (AE) i el 75,6 \% a l'assistència primària (AP). Els professionals d'infermeria de l'AE tenien més formació universitària en diabetis, en el nivell de màster o postgrau, que els de l'AP: el 12,6\% davant I'1,9\% $(p<0,001)$ i el 48,1 \% davant el $13,8 \%$ ( $p<0,001)$, respectivament, així com més formació continuada en educació terapèutica en diabetis: el 79,6\% davant el $24,8 \%$ ( $p<0,001)$.

Els professionals de l'AE referien tenir més programes d'educació estructurada en contrast amb l'AP (75,4 \% davant 51,3\%, p =0,028), però s'estima que només el $48 \%$ del total de professionals els tindria per escrit. S'estima també que un $31,8 \%$ de professionals de l'AP no té cap programa estructurat per a l'educació de pacients. Els programes que combinen les estratègies d'educació individual i grupal estan més presents a l'AE (68\% davant $48,2 \%, p=0,036)$. La participació de la família en les activitats educatives es més gran a l'AE, on un $65 \%$ de professionals responen que la família hi participa quasi sempre, davant un $32,5 \%$ a l'AP.

Hi destaca la poca coordinació entre els diferents nivells assistencials: només el 23,2 \% dels professionals de l'AP refereix tenir programes de coordinació amb l'AE, i, en canvi, un 41,3\% de l'AE diu tenir-los amb l'AP $(p<0,001)$.

Tot i que la investigació està poc desenvolupada en ambdós àmbits, hi ha una clara diferència en la producció científica pel que fa a publicacions, a favor de l'AE respecte de l'AP $(34,4 \%$ i $9,2 \%$, respectivament, $p<0,001)$.

Els rols d'educador, assessor, investigador, director, col·laborador i innovador estan més desenvolupats en la infermeria de l'AE. 
Es van observar diferències significatives entre ambdós àmbits d'assistència en l'avaluació de conductes de salut: activitat física (major percentatge en l'AP), monitoratge del control de glucèmia (major en l'AE), maneig de la medicació (major en l'AP) i adaptació psicosocial (major en l'AE). Respecte als resultats d'aprenentatge, cal destacar que a l'AE es van avaluar més i de manera significativa les habilitats tècniques (el 93,7 \% davant el $82,6 \%, p=0,037$ ), la capacitat de resolució de problemes per part del pacient (el 85,9\% davant el 57,1\%, p <0,001) i les actituds (el $81,1 \%$ davant el 60,9\%, p =0,012).

En general, els professionals de tots dos àmbits estan satisfets amb la seva feina, però sobretot amb la relació amb els companys i amb el respecte que reben dels pacients; en canvi, el seu descontentament principal té a veure amb el salari.

L'anàlisi multivariant mostra que treballar a l'AE i tenir més hores de formació acreditada són variables que s'associen a una major utilització de la via telemàtica per al control i el seguiment dels pacients. Tenir més anys d'experiència en l'assistència a persones amb diabetis, més formació en diabetis i disposar d'infraestructura (aula específica per fer-hi educació) afavoreix l'aplicació de programes d'educació terapèutica amb intervenció grupal. Quan la formació en diabetis és universitària, aquestes mateixes variables descrites anteriorment s'associen significativament amb la capacitat d'investigar i de publicar els resultats.

\section{Conclusions:}

Els professionals d'infermeria de l'assistència especialitzada:

1. Tenen més formació universitària en diabetis (màster o postgrau) i més formació continuada en diabetis i educació terapèutica.

2. Tenen més programes d'educació estructurada per a l'educació dels pacients amb diabetis i utilitzen més la via telemàtica per al control i el seguiment dels pacients. Apliquen més programes que combinen les estratègies d'educació individual i grupal.

3. Assumeixen més els rols professionals corresponents a una infermera clínica especialista.

4. Tenen més capacitat de realitzar recerca i publicar-ne els resultats.

5. Avaluen més resultats d'aprenentatge, com habilitats tècniques, resolució de problemes 0 actituds.

Els professionals d'infermeria de l'assistència primària:

1. Tenen un baix nivell de formació específica en diabetis i ET.

2. Les prestacions que ofereixen estan més centrades en els canvis de l'estil de vida i el calendari vacunal. 
En ambdós àmbits:

Cal millorar la formació en diabetis dels professionals d'infermeria i l’aplicació de programes d'educació en diabetis estructurats.

Existeix poca coordinació entre els diferents nivells d'assistència.

\section{SUMMARY IN ENGLISH}

Diabetes is a complex, chronic disease requiring continuous medical care. Ongoing patient self-management education and support are critical to prevent acute complications, reduce the risk of long-term complications and improve the quality of life of patients with diabetes. Patient therapeutic education (PTE) is one of the cornerstones of diabetes treatment since it helps patients to understand their disease and adapt to the control of diabetes in daily life and also provides the necessary support related to self-treatment to both patients and their families.

In most countries diabetes nurses lead the whole therapeutic education process. Teamwork and diabetes health professional training are key elements to ensure quality education and to obtain better therapeutic results. The skills of the health professionals must be based on biomedical aspects, culturally competent care, communication, and the use of teaching techniques in order to plan and develop educational programmes for self-management of treatment aimed at people with diabetes, family members, caregivers, and healthcare organizations, as well as to evaluate the results of these programmes.

Primary care is currently the setting in which the care of most of chronic diseases such as diabetes, particularly type 2 diabetes is provided, while patients with type 1 DM or more complex DM2 are attended by specialists .

This study was carried out in Catalonia and was developed in two phases:

Phase 1: A qualitative, historical, descriptive study was carried out with the objective of exploring the structure of the PTE units in Catalonia from the point of view of the professionals involved in their development.

Methods: An intentional sample of healthcare professionals from the medical, nursing and health administration areas involved in the organisational process and the implementation of the PTE was used. All the participants underwent a semi-structured interview and a historical review of documents from diabetes associations, the health department as well as newspaper archives was made.

Results: We interviewed 15 healthcare professionals (eight doctors and seven nurses). We identified that before the 80 's: 1 ) endocrinologists or diabetologists mainly educated the 
patients, 2) unidirectional methods such as talks or conferences were used. 3) decisions made by healthcare professionals were not discussed with patients, and only compliance with the treatment was addressed, .4) the figure of the diabetes nurse educator did not exist, and 5) the role of the nurse outside the hospital was irrelevant.

In the 80's: The "Hospital de St.Pau" and the "Hospital Clinic" in Barcelona were pioneers in the creation of PTE units with structured programmes carried out by multidisciplinary teams. The most important elements that motivated a large group of healthcare professionals to follow this approach were:1) the influence of political and social changes, and 2) scientific evidence of the benefits of these programmes reported by other countries (Europe and USA).

The implementation of PTE in the 80's and 90's was facilitated by: 1) health professional training in diabetes by the Institut Català de la Salut (IES) and the Consell Assessor sobre la Diabetis a Catalunya; 2) technological advances and the European experiences in PTE reported by Dr. Assal in Switzerland or Dr. Berguer in Germany; 3) political support and the Saint Vincent Declaration that defined the decisions related to health policies in the field of diabetes; 4) the enthusiasm and voluntarism of the healthcare professionals involved; 5 ) the role and the support provided by patient associations, and 6) the contribution of professional associations related to professional training, the development of therapeutic and educational programmes and clinical guidelines, and the integration and co-operation with patient associations.

Reforms made in the Primary Care system at the end of 90s lead to major changes in health polices which indicated that: 1 ) diabetes nurse educators in primary healthcare centres were replaced by generalist nurses; 2) there was a loss of commitment to PTE on behalf of physicians; 3 ) there was a lack of initiative by those who beliewed in diabetes education as well as a lack of leadership and educational methodology by diabetes nurses; 4).diabetes and PTE training was no longer a priority for the health administration, and 5) the mobility policies related to hospital or primary care staff did not take into account diabetes training of professionals.

Conclusions: The development of PTE started in Barcelona at the beginning of the 80's. Training in diabetes for healthcare professionals and specifically the traiing of teachers of diabetes education (Formació de professorat en educació diabetològica) together with strong political support allowed the creation of the figure of the diabetes educator nurse not only in hospital diabetes units but also in Primary Care centres.

Reforms in primary care harnessed the support of diabetes in this area in opposition to specialist care. Well trained healthcare professionals were not considered by the health authorities and diabetes educator nurses were relegated to only hospitals and some Primary Care centres, with this model remaining in place at present.

Phase 2: A descriptive, cross-sectional,comparative analysis was performed with the objective of describing the degree of PTE implementation and the level of training in diabetes, nutrition and therapeutic education of nurses in both primary and specialized care. 
Methods:The study population included diabetes nurses from specialised care (all diabetes nurses from hospitals with Endocrinology Departments) and primary care. Specialized centres with therapeutic education units were selected (46). On the other hand, cluster sampling of all primary care centres was carried out followed by the randomisation of 97 centres.

A questionnaire was adapted and validated from English to the Spanish language to be sent to the diabetes nurses of Endocrinology Departments in hospitals and Primary Care centres which were randomised prior to contact with the nursing directors of the corresponding centres.

Results: 287 questionnaires were analysed; $24.3 \%$ were from specialised care (SC) and $75.6 \%$ were from primary care (PC). Nurses working in SC had more specific diabetes training at a university level than those working in PC: master course $12.6 \%$ vs. $1.9 \%, p<0.001$ and postgraduate course $48.1 \%$ vs. $13.8 \%, p<0.001$, as well as more continuous training in PTE $79.6 \%$ vs. $24.8 \%, p<0.001$.

SC nurses used more diabetes structured programmes than nurses from PC (75.4\% vs. 51.3\%, $p=0.028)$, although it was found that only $48 \%$ of these programmes are in written form. In addition, $31.8 \%$ of PC nurses do not have any structured PTE programme. Programmes combining individual and group methods are also more frequently used in SC compared to PC (68\% vs. $48.2 \%, p=0.036)$, and $65 \%$ of PTE programmes used in SC vs. $32.5 \%$ in PC include family members.

There is a little coordination between PC and SP, with only $23.2 \%$ of PC nurses stating that they have coordinated programmes with SC, and $41.3 \%$ of SC reported having coordinated programmes with PC $(p<0.001)$.

Although there is a lack of scientific research in both SC and PC, scientific production is clearly greater in SC (34.4\%) compared to PC $(9.2 \%) \mathrm{p}<0.001$.

The roles of educator, consultant, researcher, director, collaborator and innovator are more developed in nurses from SC.

Significant differences between the two areas of care in the evaluation of health behaviour were important: physical activity (greater in PC), monitoring of glycemic control (greater in SC), medication management (greater in PC) and psychosocial adaptation (greater in SC). Regarding the results of patient learning, it was of note that SC significantly improved the technical skills (93.7\% vs. $82.6 \%) p=0.037$, problem solving $(85.9 \%$ vs. $57.1 \%) p<0.001$, and the attitudes of the patients $(81.1 \%$ vs. $60.9 \%) p=0.012$.

In general, nurses from both PC and SP were satisfied with their jobs, and their greatest dissatisfaction was with their salaries.

Multivariant analysis showed that the variables of working in SC and having a greater number of hours of acredited diabetes training were associated with the presence of greater telematic 
systems for diabetes control. It was found that having more experience in providing diabetes treatment, more diabetes training and infrastructure such as specific space for diabetes education promotes the development of PTE programmes with group intervention. Moreover, university training in the above mentioned areas was also significantly associated with the ability to investigate and publish the results.

\section{Conclusions:}

Specialized care nurses:

1. Have more university diabetes training (master or postgraduate courses) and receive more continous diabetes training in diabetes and therapeutic education.

2. Develop more structured diabetes programmes and more frequently use telematic methods to follow and control patients with diabetes. In addition, their PTE programmes more often combine individual and group education strategies.

3. Take on a more professional role which unquestionably corresponds to a diabetes specialist nurse.

4. Have greater capacity to carry out investigation and publish results.

5. Evaluate the results of learning such as technical skills, problems solving or attitudes.

Primary Care nurses:

1. Have a low level of specific training in diabetes and therapeutic education.

2. Provide care more focused on lifestyles and the vaccination schedule.

Primary and specialized care nurses:

1. Diabetes training and the application of the PTE programmes for both areas of nursing should be improved.

2. There is a lack of coordination between primary and specialized care. 


\section{ÍNDEX DE CONTINGUTS}

AGRAÏMENTS

ABREVIACIONS

RESUM

SUMMARY IN ENGLISH

ÍNDEX DE CONTINGUTS

ÍNDEX DE FIGURES

ÍNDEX DE GRÀFICS

ÍNDEX DE TAULES

\section{MOTIVACIÓ PERSONAL PER REALITZAR LA TESI}

\section{INTRODUCCIÓ}

2.1. La diabetis mellitus: classificació i epidemiologia

2.2. Repercussions de la diabetis en la vida de la persona i el seu entorn

2.2.1. L'impacte del diagnòstic

2.2.2. El procés d'adaptació a la malaltia

2.2.3. Les dificultats per a la gestió del tractament

2.2.4. La diabetis en les diferents etapes de la vida

\section{MARC TEÒRIC}

3.1 Concepte de salut i la seva evolució

3.1.1. Determinants de la salut

3.1.2. Del model biomèdic al model biopsicosocial d'atenció a la salut. Atenció centrada en el pacient

\subsection{Concepte d'educació}

3.2.1. Educació sanitària / Educació per a la salut

3.2.2. El paper de l'educació en el tractament de la diabetis. Perspectiva històrica i tendències actuals

3.2.3. Posicionament de les societats científiques sobre l'educació terapèutica i els estàndards de qualitat

3.2.4. Evolució del paper de la infermera en l'educació de les persones amb diabetis

3.2.5. Formació i acreditació en diabetis dels professionals d'infermeria

3.2.6. Rol i competències de la infermera en diabetis. Dificultats en la seva definició

3.3. Marc assistencial de la diabetis a Catalunya. El paper de la infermera

3.3.1. Descripció dels diferents nivells d’atenció 


\section{JUSTIFICACIÓ DE LA INVESTIGACIÓ}

4.1. Investigació històrica

4.2. Investigació qualitativa

5. OBJECTIUS

\section{DISSENY I METODOLOGIA DE LA INVESTIGACIÓ}

6.1. Primera fase de l'estudi

6.2. Segona fase de l'estudi

6.3. Aspectes ètics

\section{RESULTATS}

7.1. Resultats de la primera fase de l'estudi

7.1.1. La diabetis a Catalunya en la dècada dels setanta

7.1.2. Dècada dels vuitanta. Procés d'implementació de l'«educació diabetològica» a Catalunya

7.1.3. De la dècada dels noranta fins a l'actualitat. Evolució de l'educació terapèutica en diabetis a Catalunya

7.1.4. Visió actual de l'educació terapèutica en diabetis per part dels professionals implicats

7.1.5. Visió de futur de l'educació terapèutica en diabetis per part dels professionals implicats

7.2. Resultats de la segona fase de l'estudi

7.2.1. Característiques sociodemogràfiques i perfil professional

7.2.2. Formació específica i experiència en diabetis

7.2.3. Càrregues de treball

7.2.4. Relació/col·laboració amb altres professionals

7.2.5. Prestacions, estructura de l'educació terapèutica, tipus d'educació i recursos

7.2.6. Indicadors de resultats

7.2.7. Investigació

7.2.8. Rols de la infermeria en l'assistència a la diabetis

7.2.9. Grau de satisfacció personal respecte del treball que desenvolupa

7.2.10. Anàlisi multivariant

7.2.11. Observacions i propostes de millora

8. DISCUSSIÓ

9. CONCLUSIONS

10. BIBLIOGRAFIA

11. ÍNDEX D'ANNEXOS 


\section{ÍNDEX DE FIGURES}

Figura 1: Model de determinants de la salut

\section{ÍNDEX DE GRÀFICS}

Gràfic 1: Distribució per províncies del total de la mostra

Gràfic 2: Distribució de la mostra per províncies i tipus d'assistència

Gràfic 3: Àmbit territorial (total de la mostra)

Gràfic 4: Àmbit territorial per tipus d'assistència

Gràfic 5: Publicacions científiques derivades de les intervencions educatives

Gràfic 6: Rol de pràctica clínica

Gràfic 7: Rol educador (pacients, famílies i públic en general)

Gràfic 8: Rol educador (educació a altres professionals)

Gràfic 9: Rol assessor o consultor (en relació amb l'organització)

Gràfic 10: Rol assessor o consultor (en relació amb els professionals, pacients i família)

Gràfic 11: Rol investigador

Gràfic 12: Rol director

Gràfic 13: Rol col·laborador-enllaç

Gràfic 14: Rol innovador

Gràfic 15: Grau de satisfacció personal en relació amb La feina 


\section{ÍNDEX DE TAULES}

134 Taula 1: Comunicacions presentades a la IV Jornada de I'Associació Catalana d'Educadors en Diabetis (Sabadell 1988)

Taula 2: Treballs presentats a congressos. Dècada dels noranta

Taula 3: Importància que dona el Pla de Salut de Catalunya a l'Educació Terapèutica en Diabetis

Taula 4: Característiques personals i perfil professional de la població estudiada

Taula 5: Edat mitjana dels professionals per àmbit d'assistència

Taula 6: Formació i experiència en diabetis dels professionals per àmbit d'assistència

Taula 7: Total de pacients amb diabetis i percentatge de pacients atesos segons el tipus de diabetis en un mes en cada àmbit d'assistència

Taula 8: Distribució d'edats dels pacients atesos per àmbit d'assistència (percentatge)

Taula 9: Pacients amb barreres idiomàtiques (percentatge)

Taula 10: Relació/col·laboració amb altres professionals, per àmbit d'assistència

Taula 11: Prestacions que els professionals d'infermeria ofereixen als pacients, per àmbit d'assistència

Taula 12: Estructura, tipus d'educació terapèutica i recursos, per àmbit d'assistència

Taula 13: Temps de la jornada laboral dedicat a l'educació terapèutica dels pacients amb diabetis per àmbit d'assistència (percentatge)

Taula 14: Resultats de conductes de salut, aprenentatge i clínics que s'avaluen i es registren de forma sistemàtica, per àmbit d'assistència

Taula 15: Associació entre el tipus d'educació (individual/grupal) i diferents característiques dels professionals i centres 
Taula 17: Associació entre la utilització de la via telefònica per al control i seguiment dels pacients i diferents característiques dels professionals i centres

Taula 18: Associació entre la utilització de plataformes de descàrrega de mesuradors de resultats del control glucèmic i diferents característiques dels professionals i centres

Taula 19: Associació entre la utilització de plataformes per a la descàrrega de bombes i sensors i diferents característiques dels professionals i centres

Taula 20: Associació entre la utilització de programes educatius en línia i diferents característiques dels professionals i centres

Taula 21: Associació entre la utilització d'altres vies per al seguiment i la comunicació amb els pacients i diferents característiques dels professionals i centres

Taula 22: Associació entre publicacions i diferents característiques dels professionals i centres

Taula 23: Grau de satisfacció personal dels professionals en relació amb el treball (suma de tots els ítems)

Taula 24: Satisfacció pel temps de dedicació als pacients, a la pròpia formació i a l'organització de la feina

Taula 25: Satisfacció amb el temps d’oci i la dedicació a la família

Taula 26: Satisfacció per la relació amb els companys i amb els pacients

Taula 27: Satisfacció per la possibilitat o facilitat de consultar amb especialistes o altres professionals experts en educació terapèutica i diabetis 


$$
26
$$




\section{MOTIVACIÓ PERSONAL PER REALITZAR LA TESI}

Treballo al mateix hospital des de que vaig acabar la carrera d'infermera a l'any 1978. La meva experiència sempre havia estat en plantes d'hospitalització de Medicina Interna on hi havia el servei d'Endocrinologia. En aquella època, tots els debuts de diabetis, tant de tipus 1 com de tipus 2, així com les persones amb diabetis descompensada s'ingressaven per optimització del control. M'agradava tractar amb aquesta patologia.

Jo era infermera del torn de tarda. Les infermeres del torn de tarda no teníem tant contacte amb els metges del Servei, però amb la meva companya, la Carme Viñas, fèiem educació en la tècnica d'administració de la insulina a aquells pacients que s'insulinitzaven durant l'ingrés hospitalari i també repàs del pla d'alimentació. Ningú ens ho havia demanat però pensàvem que era important perquè la persona no arribés a casa sense tenir uns mínims coneixements i habilitats respecta al control de la seva diabetis.

L'any 1986, gràcies a la motivació de dos dels endocrinòlegs del Servei, el Dr. Ricard Torras i el Dr. Jordi Anglada, vaig tenir la oportunitat de fer formació en Educació Diabetològica en els cursos organitzats per l'Institut d'Estudis de la Salut amb el suport del Consell Assessor sobre la Diabetis a Catalunya, el curs bàsic de diabetis i el de Perfeccionament.

Aquí es on vaig reafirmar-me en que el que m'agradava era l'àmbit de l'educació del malalt amb diabetis i de la seva família. Un cop acabada aquesta formació varem demanar juntament amb dues companyes més que també havien fet els cursos, la possibilitat de fer educació grupal a tots aquells pacients amb diabetis ingressats a l'hospital, fins i tot d'altres Serveis. La Carmen del Solar, la directora d'infermeria d'aquell moment, ens ho va concedir i, a més, com que ho fèiem fora d'hores de feina, ens ho van remunerar.

Finalment a l'any 1991, gràcies a la motivació del ja Cap de Servei d’Endocrinologia, el Dr. Jordi Anglada i el Director Mèdic, Dr. Rossell, es va crear la primera UDEN (Unitat d'Endocrinologia i Nutrició) de Catalunya. Per allò d'estar en el lloc adequat en el moment adequat, se'm va proposar la plaça com educadora de diabetis de la Unitat.

Durant tots aquests anys he sigut molt feliç fent la feina que més m’agrada, l'educació de les persones amb diabetis i les seves famílies. He intentat formar-me contínuament, també he fet molta docència i m'he implicat en la formació de les infermeres de l'hospital. Però tinc la sensació d'haver fet molta feina i poca recerca. Crec que $\mathrm{m}^{\prime}$ ha faltat metodologia de treball. 
Per tant, al decidir fer el Màster en Ciències de la Infermeria vaig pensar que m'ajudaria a aprendre unes matèries que, penso, $m$ 'han fet falta per fer una mica més de recerca. A més, em donava peu a fer el Doctorat i, per tant, $m^{\prime}$ he proposat ja per fi, fer la Tesi. I com no podia ser d'una altra manera, la dedico a l'Educació Terapèutica en la Diabetis, la seva importància que té en el tractament de la malaltia i com ha evolucionat al llarg del temps a Catalunya.

Aquesta tesi pretén estudiar a fons les motivacions dels professionals que van sentir la necessitat de canviar el paradigma en la atenció a las persones amb diabetisi el procés que ha seguit l' Educació Terapèutica en diabetis a Catalunya.

Amb aquest treball pretenc complir amb dos objectius, per a mi fonamentals en els meus anys de vida laboral dedicada a l'Educació Terapèutica en la Diabetis. El primer és donar a conèixer les motivacions i les vivències d'uns professionals que interessats per ajudar a millorar el control de les persones amb diabetis, es van implicar a fons per buscar noves maneres d'abordar el tractament dedicant esforços i recursos. Professionals il · lusionats pel descobriment d'un nou camp, el de la pedagogia aplicada a l' educació per a la salut, que obria la possibilitat d'ajudar d'una manera més eficaç als pacients amb diabetis. Es van implicar en la formació no només d'ells mateixos sinó que van crear una xarxa de professionals formats, la majoria infermeres en les quals m'incloc.

El segon és comprovar com , després del pas dels anys i un llarg procés de canvis en l'organització sanitària , s'està duent a terme en el moment actual l' educació terapèutica en diabetis a Catalunya. 


$$
0
$$

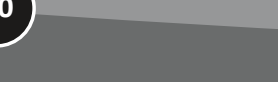




\section{INTRODUCCIÓ}

\subsection{La diabetis mellitus: classificació i epidemiologia}

La DM és un trastorn metabòlic caracteritzat per un estat d'hiperglucèmia crònica resultant dels defectes en la secreció i/o acció de la insulina ${ }^{1}$. És una malaltia crònica que requereix atenció mèdica continuada, educació terapèutica del pacient per a l'autogestió del tractament i suport permanent per tal d'evitar complicacions agudes (hipoglucèmia i hiperglucèmia), de reduir el risc de complicacions cròniques i de millorar la qualitat de vida ${ }^{2}$. Està associada a danys a llarg termini de diferents òrgans (complicacions cròniques de la DM), com ara la retinopatia, la nefropatia, la neuropatia i la vasculopatia.

$\mathrm{Hi}$ ha diferents tipus de diabetis i opcions terapèutiques segons la seva etiologia i evolució de la malaltia. S'engloben en quatre tipus d'entitats etiopatogèniques ${ }^{1}$ :

- Diabetis mellitus de tipus 1 (DM1): Es produeix per una destrucció de les cèl-lules beta del pàncrees, cosa que comporta una deficiència absoluta d'insulina. El tractament ha de ser amb insulina des del moment del diagnòstic de la malaltia, teràpia nutricional i educació del pacient i/o família per a l'autogestió del tractament.

- Diabetis mellitus de tipus 2 (DM2): Es deu a un defecte progressiu en la secreció d'insulina i a un estat de resistència a la insulina. Depenent del moment de l'evolució de la malaltia i del control metabòlic, el tractament ha de ser amb teràpia nutricional, activitat física, antidiabètics orals/injectables i/o insulina. Representa gairebé el $90 \%$ de tots els tipus de DM.

- Altres tipus específics de DM: S'hi inclouen aquelles causades per defectes genètics en la funció de les cèl-lules beta, defectes genètics en l'acció de la insulina, malalties del pàncrees exocrí (com la fibrosi quística), fàrmacs (corticoides o immunosupressors), o bé induïdes per productes químics, com en el cas del tractament del VIH/SIDA o després del trasplantament d'òrgans.

- Diabetis gestacional (DMG): És la diabetis diagnosticada durant l'embaràs que desapareix després del part, tot i que és un factor de risc de desenvolupar posteriorment una DM2.

Els símptomes que acompanyen la hiperglucèmia són: polidípsia (augment de la set), poliúria (orinar en excés) i pèrdua de pes, tot i que hi ha un augment de la gana; de vegades pot ocasionar visió borrosa o susceptibilitat a les infeccions.

Els criteris diagnòstics de la DM aprovats per l'American Diabetes Association (ADA) el 1997², acceptats pel comitè assessor de l'Organització Mundial de la Salut (OMS) ${ }^{4}$ i pel Consensos Europeu $^{5}$, vigents en l'actualitat ${ }^{6}$, es realitzen d'acord amb criteris de valors de glucosa plas- 
màtica en dejú $\geq 126 \mathrm{mg} / \mathrm{dl}(7 \mathrm{mmol} / \mathrm{L})$ o $\geq 200 \mathrm{mg} / \mathrm{dl}(11,1 \mathrm{mmol} / \mathrm{L})$ després de 2 hores de l'administració de $75 \mathrm{~g}$ de glucosa per via oral. També s'aplica el diagnòstic de DM a aquelles persones amb símptomes clars d'hiperglucèmia o una glucosa plasmàtica a l'atzar $\geq 200 \mathrm{mg} / \mathrm{dl}$ (11,1 mmol/L). Recentment, un comitè d'experts internacional va afegir com a criteri diagnòstic un valor d'hemoglobina glucosilada (HbA1c) $\geq 6,5 \%$ \% . L'ús del valor d'HbA1c per al diagnòstic de la DM ha estat molt controvertit ${ }^{9}$, especialment per la falta d'un mètode analític estandarditzat i d'un nivell de referència uniforme de persones no diabètiques entre diversos laboratoris. A Espanya es considera un criteri acceptat pel fet que està inclòs a totes les guies clíniques ${ }^{10}$.

- Prediabetis: Al 1997 i al 2003 el Comitè d'Experts del Diagnòstic i Classificació de la Diabetis ${ }^{11,12}$ va definir un grup de persones en els quals, encara que els seus nivells de glucosa no compleixen els criteris de diabetis, aquests són massa alts per ser considerats normals. Parlem, doncs, de glucosa basal alterada (GBA) quan la glucèmia plasmàtica en dejú està entre 100 i $125 \mathrm{mg} / \mathrm{dl}$, o d'intolerància oral a la glucosa (IOG) quan la glucosa plasmàtica després de 2 hores d'una sobrecàrrega oral de $75 \mathrm{~g}$ de glucosa està entre 140 i $199 \mathrm{mg} / \mathrm{dl}$. Tant la GBA com la IOG són estats de prediabetis, cosa que indica un risc relativament alt d'un desenvolupament futur de diabetis i de malaltia cardiovascular. La prediabetis està associada a obesitat, especialment abdominal o visceral, a dislipèmia i a hipertensió arterial (HTA).

Des de no fa gaire hi ha una forta evidència que intervencions sobre l'estil de vida en persones diagnosticades de prediabetis disminueixen la incidència de DM2 en un $58 \%$ dels $\operatorname{casos}^{13}$. A Catalunya, l'estudi DE-PLAN-CAT ${ }^{14}$, realitzat en l'àmbit de l'AP i dins la pràctica clínica habitual, ha demostrat que pot reduir fins a un $36 \%$ el risc relatiu de desenvolupar DM2, només amb modificacions de l'estil de vida.

La DM és una de les malalties cròniques més prevalents. Afecta totes les edats i condicions socials i constitueix un greu problema de salut en tot el món. Al 2013, segons la International Diabetes Federation (IDF) ${ }^{15,16}$ hi havia al món 382 milions de persones amb diabetis, i s'estima que per a l'any 2035 n'hi haurà 592 milions (un increment en població adulta del 55 \%). A causa de la diabetis, el 2013 van morir 5,1 milions de persones entre 20 i 79 anys (el $48 \% \leq$ 60 anys), fet que representa una mortalitat del $8,4 \%$ i que equival a una mort cada 6 segons per aquesta causa.

La prevalença de la DM2 ha anat creixent amb el pas dels anys a causa d'una major esperança de vida, el canvi dels patrons alimentaris i l'estil de vida sedentari. A España la prevalença de la DM2 en la població més gran de 18 anys, segons dades de l'estudi di@bet.es ${ }^{17}$, publicades el 2011, és del 13,8 \%; gairebé la meitat (un $6 \%$ ) d'aquestes persones desconeixen que tenen la malaltia. La prevalença és més alta en homes i augmenta amb l'edat. En la franja de 61-74 anys té diabetis un $24,8 \%$ dels homes i un $18,7 \%$ de les dones. La prevalença de prediabetis (GBA o IOG) és del $14,8 \%$. Segons aquest estudi, els factors de risc de desenvolupar diabetis són l'edat, el sexe masculí, un baix nivell d'estudis, la història familiar de DM, la presència d'HTA i l'obesitat, especialment la de predomini abdominal. 
La DM1 també va en augment. En el món es calcula un increment anual del $3 \%^{16}$. Les causes no estan clares, però es pot deure a canvis en els factors de risc mediambientals, successos primerencs en l'úter, l'alimentació dels primers anys de vida o infeccions virals. La incidència de la DM1 en el nostre medi és de 12-15 casos per 100.000 persones/any ${ }^{18}$.

Malgrat que a Espanya no hi ha estudis recents sobre la prevalença de la diabetis gestacional, amb l'aplicació dels nous criteris diagnòstics s'estima un percentatge del $11,8 \%{ }^{19}$.

Actualment, la diabetis és la causa més important de discapacitat i mort, especialment com a conseqüència de les complicacions cròniques associades ${ }^{15}$. Aquestes complicacions augmenten amb l'edat i amb el temps d'evolució de la malaltia.

La retinopatia és la primera causa de ceguesa al món occidental ${ }^{20}$. A Espanya, segons dades estadístiques del 2005 de l'Organización Nacional de Ciegos de España (ONCE), és la tercera causa de ceguesa ${ }^{21}$. La prevalença de retinopatia diabètica varia segons els estudis i els grups poblacionals. A Espanya, el 2007 es va descriure una prevalença del 15-50 \% ${ }^{22}$ i a Catalunya, un estudi recent en població amb DM2 mostra una prevalença del 12,3 \% ${ }^{23}$.

La nefropatia es considera la primera causa d'insuficiència renal crònica tant en pacients amb DM1 com amb DM2, amb una prevalença que varia segons les sèries entre el $20-50 \%{ }^{24}$.

La polineuropatia diabètica és la complicació crònica més freqüent de la diabetis. La prevalença augmenta amb l'edat i els anys d'evolució de la malaltia. S'estima que afecta el $50 \%$ de les persones amb $\mathrm{DM}^{25}$, i és la principal responsable del risc d'amputació a extremitats inferiors. Els darrers estudis a Espanya mostren una prevalença del $22-40 \%{ }^{22}$.

Respecte de la vasculopatia, es destaca que la malaltia coronària, la patologia vascular cerebral o la malaltia vascular perifèrica són entre dos i quatre vegades més freqüents ${ }^{2}$ en persones amb diabetis. El risc de mort per problemes cardiovasculars és el doble que en persones no diabètiques. Un bon control metabòlic des del diagnòstic ha demostrat prevenir o endarrerir l'aparició de complicacions. Es requereix, però, un tractament multidisciplinari i una alta implicació del pacient en la gestió de la seva malaltia.

L'elevada prevalença de la DM i l'impacte de les seves complicacions tenen una gran repercussió socioeconòmica. Això es tradueix en un augment substancial dels pressupostos de salut dels països. Als EUA, l'any 2012 la diabetis va representar un cost de 245 bilions de dòlars, dels quals 176 (el $72 \%$ ) representaven costos directes i la resta, 69 bilions de dòlars, costos indirectes, com falta de productivitat per absentisme laboral, desocupació per discapacitat a causa de les complicacions cròniques o mort prematura ${ }^{26}$. A Espanya la diabetis representa un 8,2 \% de la despesa total del Sistema Nacional de Salut ${ }^{27}$.

Existeix una evidència suficient que demostra que per fer front a aquesta situació d'alta morbimortalitat i costos associats és necessari: 
- El diagnòstic i tractament precoç de la malaltia ${ }^{26}$

- L'optimització del control metabòlic des del diagnòstic de la malaltia ${ }^{28,29,30,31} \mathrm{El}$ control dels factors de risc cardiovascular (FRCV) $)^{32,33,34}$

- L'ET del pacient i de les seves famílies o cuidadors ch,36 $^{35,3}$

Tot i l'existència a diferents països europeus d'estratègies nacionals i governamentals dissenyades perquè els serveis de salut afrontin de manera eficaç i eficient la malaltia, en la pràctica, la seva aplicació no és l'esperada, tal com subscriu la IDF ${ }^{37,38}$. Per aquest motiu s'han elaborat eines per intentar sensibilitzar els polítics, en què se'ls informa de la importància de la prevenció, l'autogestió i l'atenció centrada en la persona ${ }^{39}$, per tal que adoptin mesures de política sanitària favorables a millorar la qualitat de l'atenció i minimitzar l'impacte de la malaltia.

\subsection{Repercussions de la diabetis en la vida de la persona i el seu entorn}

\subsubsection{L’impacte del diagnòstic}

El diagnòstic d'una malaltia crònica com la DM suposa un impacte en la vida de la persona que es pot viure com una amenaça a la seva integritat. Comporta la necessitat d'una modificació de l'estil de vida, que repercutirà en la seva rutina diària, al qual haurà de fer front des del principi. Genera, per tant, un gran nombre de respostes humanes derivades de la por o la incertesa davant una nova situació que poden alterar necessitats bàsiques i deteriorar la qualitat de vida de l'individu, limitant la seva autonomia. Hi ha la sensació de pèrdua de la salut, de llibertat i de normalitat, i també una sensació d'impotència davant una nova situació que sovint suposa un greu problema d’adaptació i superació.

Hi ha estudis que demostren que el moment més impactant dins del procés de malaltia crònica és el de la comunicació del diagnòstic, ja que marca el començament d'una nova etapa en la qual es començaran a reestructurar les diverses àrees de la vida i es construiran nous sentits ${ }^{40}$. Quan una persona rep el diagnòstic d'una malaltia com la diabetis es desencadena una sèrie de reaccions, de vegades contradictòries, que varien segons l'edat, el sexe, les referències que tingui sobre la malaltia, la cultura, les creences, el tipus de diabetis, la forma de presentació i, inclús, segons la manera com el professional dona la notícia. Algunes persones no són conscients del que representa, mentre que d'altres es queden bloquejades i no poden rebre ni entendre la informació dels professionals ${ }^{41}$.

Aquests canvis en la persona diabètica que genera el diagnòstic de la malaltia, sovint afecten també la família, sobretot amb la que conviu. La família sol ser el principal suport del pacient i a vegades se la fa també corresponsable del seu compliment terapèutic. La persona afectada i la família han de posar en marxa una sèrie de mecanismes psicològics i emocionals per afrontar la nova situació i el dol que suposa la pèrdua de la salut. Quan una persona no desenvolupa 
els recursos psicològics adequats, apareixen alteracions psicopatològiques que influeixen de manera negativa en l'adaptació a la malaltia i en la seva evolució. En la diabetis, els trastorns més freqüents que s'han descrit són els estats d'ansietat, depressió i alteració de la conducta alimentària. Els professionals han de poder detectar els indicadors de mala adaptació a fi d'actuar-hi de manera precoç i garantir una millor evolució i qualitat de vida ${ }^{42,43}$.

\subsubsection{El procés d’adaptació a la malaltia}

El fenomen d'adaptació a una malaltia crònica és un procés complex, en el qual intervenen diverses variables que seran diferents depenent dels recursos que faci servir cada persona. S'han descrit diferents models explicatius del procés d'adaptació a la malaltia que provenen dels camps de la psicologia i de la pràctica clínica ${ }^{44,45}$. Seguidament en veurem els principals.

\subsubsection{Model d'adaptació de Roy ${ }^{46}$}

Callista Roy, infermera nord-americana, va descriure el seu model d'adaptació l'any 1976 basant-se en la seva experiència personal i professional, en observar la facilitat amb què els nens s'adaptaven als canvis ocasionats per la malaltia i a les seves creences amb relació a l'ésser humà. Descriu la persona com un sistema adaptatiu holístic que interactua constantment amb els estímuls d'un entorn dinàmic i canviant, però la resposta pot ser adaptativa, si promou els objectius d'adaptació i integritat, o no adaptativa, quan no promou la integritat ni contribueix als objectius d'adaptació i integració de les persones amb el món. Per Roy, l'ambient és «tot allò que provoca una resposta», és a dir, totes les condicions que envolten i afecten la conducta de la persona, i que categoritza d'aquesta manera: $a$ ) estímuls focals (aquells que desencadenen una resposta immediata en el pacient, que pot ser adaptativa o inefectiva, segons si es promou o no l'adaptació); $b$ ) estímuls contextuals (els que poden contribuir a l'efecte de l'estímul focal, és a dir, ajuden a millorar o empitjorar la situació), i c) estímuls residuals (inespecífics, com poden ser les actituds davant la malaltia de les quals la persona no té plena consciència, però que influeixen en la seva conducta).

Des d'aquest punt de vista, el nivell d'adaptació d'una persona és un punt en contínua modificació. Els processos d'afrontament poden ser innats (genèticament determinats i vistos com a processos automàtics i inconscients) o adquirits (desenvolupats a través d'estratègies d'aprenentatge, judici i emocions). Aquest és un model centrat bàsicament en l'àmbit de la infermeria.

\subsubsection{Models basats en la clínica}

Són aquells que se centren en la identificació de les etapes per les quals passa un individu quan li diagnostiquen una malaltia, així com dels components cognitivo-afectivo-conductuals de cadascun. A continuació se'n detallen els més rellevants: 


\section{- Model de Külbert Ross ${ }^{47}$}

Aquest model descriu les etapes del procés de dol d'una malaltia terminal, i també s'ha utilitzat per descriure el procés d'acceptació d'una malaltia crònica ${ }^{48,49}$. Les fases del procés són:

- Negació: Es refereix a la impossibilitat d'acceptar i reconèixer que es tingui la malaltia. El diagnòstic s'atribueix a un error mèdic o a una equivocació de les proves realitzades. Se sol buscar informació que desmenteixi el diagnòstic. Lazarus i Folkman $(1986)^{50}$ sostenen que aquesta negació en un primer moment pot tenir una funció protectora, ja que redueix els nivells d'estrès generats pel diagnòstic, però si persisteix pot alterar d'alguna manera el tractament que cal seguir, perquè si el pacient nega la malaltia, no accepta el tractament i, per tant, no si adhereix.

- Ira: Es defineix com una reacció emocional de ràbia, enveja, ressentiment i hostilitat per haver perdut la salut. Aquest sentiment va dirigit a tot l'entorn que es percep com a sà o responsable de la malaltia, ja sigui personal, sanitari, els familiars, les amistats o fins i tot Déu. De vegades també es pot produir la ira cap a un mateix, quan un es culpabilitza d'haver-se provocat la malaltia, fet que pot portar a adoptar conductes d'autodestrucció.

- Pacte/negociació: Les persones contra les quals s'havia dirigit la ira ja no es veuen com a culpables, sinó com a compromesos amb la seva recuperació. L'individu comença a acceptar la malaltia i fa promeses per arribar a objectius terapèutics. Intenta manipular el tractament, hi ha consciència de malaltia, però el pacient, en lloc de revoltar-s'hi, negocia.

- Depressió: És la resposta emocional que té lloc quan el pacient s'adona dels canvis i les repercussions de la malaltia. En aquesta fase pot abandonar el seguiment terapèutic. Gfeller i Assal ${ }^{51}$ diferencien entre depressió psiquiàtrica, que és poc freqüent i precisa tractament específic, i depressió amb esperança, que es pot considerar adequada, adaptada a la situació, ja que és meditativa i creativa i el malalt, tot i estar trist, no perd l'esperança.

- Acceptació: Es produeix el reconeixement de la malaltia. S'adopta una actitud de lluita i supervivència, que no s'ha de confondre amb la resignació. Hi ha un retrobament de l'equilibri emocional que permet afrontar el tractament i les seves implicacions. 


\section{- Model de Shontz ${ }^{52,53}$}

Defineix tres etapes que apareixen quan l'individu s'enfronta a una malaltia greu des del moment del diagnòstic:

- Xoc: Quan la malaltia es presenta de sobte, la persona queda astorada i reacciona manifestant un cert distanciament del problema, com si no li estigués passant a ell. De vegades reacciona amb una sorprenent claredat i eficàcia, tant de pensament com d'acció.

- Trobada Aquesta etapa es caracteritza per sentiments de pèrdua, desesperança i pensament desorganitzat.

- Retirada: És una fase que correspondria inicialment a la fase de negació, però progressivament el pacient es va comprometent amb la realitat.

\subsubsection{Models basats en estudis d'estrès i adaptació}

Des d'una perspectiva més àmplia, el procés d'adaptació a les malalties cròniques també s'ha estudiat des dels treballs experimentals sobre estrés i adaptació. Lazarus i Folkman ${ }^{47}$ defineixen l'estrès com una interacció de la persona amb el seu entorn. L'aparició d'estrès dependrà de l'impacte que produeix en la persona o dels recursos de què aquesta disposa per afrontar-los. Per explicar el fenomen general d'adaptació a la malaltia des d'aquest marc teòric, s'han proposat els models d'autoregulació. En tant que una persona desenvolupi processos d'autoregulació, la seva dependència de l'exterior serà menor i, per tant, es podrà adaptar amb més garanties a qualsevol situació. Hi ha diferents models:

- Model de Worden ${ }^{54}$

Aquest autor entén el dol com el compliment de quatre tasques:

- Acceptar la realitat de la pèrdua i construir el món sense l'objecte perdut, que en aquest cas és la salut.

- Treballar les emocions i el dolor de la pèrdua, és a dir, donar sentit als sentiments associats a la pèrdua i integrar-los en aquest nou món.

- Adaptar-se a un medi sense la persona o l'objecte perdut.

- Recol·locar-se emocionalment. 


\section{- Model de Leventhal, Meyer i Nerenz}

Un dels models teòrics més recents que utilitzen la representació de la malaltia per entendre com les persones l'afronten és el proposat per Leventhal, Meyer i Nerenz ${ }^{55}$. El principal supòsit d'aquest model és que les creences sobre la malaltia influeixen en la resposta d'afrontament dels pacients, i aquesta al seu torn influeix en els resultats, com ara la qualitat de vida i l'efectivitat del tractament. Segons aquest model, la resposta d'una persona és producte d'un sistema que involucra tres processos:

- Entrada: El pacient dona significat a la malaltia a partir d'estímuls interns i externs, és a dir, fa una interpretació del que li està passant.

- Sortida de respostes: Desenvolupa un pla d'acció d'acord amb les representacions que ha elaborat.

- Autoobservació: El pacient avalua els resultats de les estratègies d'afrontament que ha desenvolupat a partir del pla d'acció.

En la DM, diversos estudis han mirat de conèixer el procés d'adaptació de la malaltia segons alguns d'aquests models. En un estudi en el qual es va intentar descriure el procés d'adaptació a la DM1 a partir del model de Kúbler-Ross ${ }^{56}$, hi destaquen diferències percebudes en les diferents fases entre els pacients, familiars i professionals sanitaris. Els professionals sanitaris sostenen que la negació és la manifestació més habitual tant dels pacients com dels familiars a l'inici de la malaltia, i que es mantenen en aquesta fase durant anys. Atribueixen a la negació la mala adherència terapèutica i el mal control. Per contra, els pacients i els familiars diuen que no hi ha negació sinó incredulitat i sorpresa davant un diagnòstic inesperat. Ells interpreten la negació persistent com una sensació d'invulnerabilitat. La fase d'ira o rebel-lia s'identifica bé d'acord amb el model, tant per part dels pacients com dels familiars, però els professionals no toleren bé aquesta fase, ja que se senten agredits per les actituds dels pacients i les valoren com un rebuig al tractament. La fase de negociació és molt reconeguda pels professionals com una part essencial en la relació, però poc reconeguda pels pacients i familiars. Generalment, tant els pacients com la família manifesten tristesa en lloc de símptomes depressius, però quan la tristor persisteix en el temps els professionals l'identifiquen com a depressió i els obliga a buscar ajuda psicològica. D’altra banda, els pacients consideren que mai s'arriba a acceptar la malaltia, raó per la qual sembla més lògic parlar d’adaptació que no pas d’acceptació.

Un altre treball que va estudiar la relació entre l'estrès percebut i les estratègies d'afrontament cognoscitiu en pacients amb DM2, en aquest cas segons el model d'adaptació de Roy, va demostrar que l'estrès percebut disminueix les estratègies d'afrontament i l'adaptació fisiològica i psicosocial dels pacients ${ }^{57}$. 


\subsubsection{Les dificultats per a la gestió del tractament}

Sovint els professionals de la salut lluitem per tractar una malaltia crònica el tractament de la qual està en mans de la persona que la pateix. Malgrat els esforços per aconseguir que el pacient adopti o canviï certs hàbits associats a l'autocura, molts cops els professionals ens sentim frustrats quan ens adonem que no estan disposats a seguir els nostres consells i assolir els resultats desitjats. Sovint aquesta falta d'adherència als comportaments d'autocura es produeix perquè els plans de tractament no s'adapten a les necessitats de la persona afectada, ja que aquestes, en general, depenen dels seus valors i estils de vida i de factors psicosocials ${ }^{58}$.

Segons l'OMS ${ }^{59}$, la capacitat dels pacients per seguir els plans de tractament d'una manera òptima depèn dels factors següents:

\section{- Factors socioeconòmics}

- Sistema i/o equip d'atenció de salut

- Característiques de la malaltia

- Complexitat del tractament

- Factors relacionats amb el pacient

Des del camp de la psicologia, fa anys que hi ha hagut un interès especial a estudiar quines són les barreres psicosocials que poden afectar el control de la diabetis ${ }^{60}$, ja que tot i els avenços en els tractaments i els sistemes de control, els resultats no són els esperats.

Tenir cura de l'estat emocional és una part important del tractament de la diabetis i de l'autogestió de la malaltia. Els problemes psicològics i socials poden inhibir o disminuir la capacitat de dur a terme totes les tasques d'autogestió de la malaltia, tant de la mateixa persona amb diabetis com de la seva família, i per tant es pot posar en perill el seu estat de salut ${ }^{61}$. Diferents estudis mostren que encara ara la diabetis suposa un estigma en la societat: el caràcter crònic de la malaltia, les demandes que comporta i el perill de patir hipoglucèmies contribueixen a augmentar l'ansietat i els símptomes depressius dels pares de nens i joves amb diabetis ${ }^{62}$.

Al 2001, l'estudi DAWN163 l'estudi més gran realitzat fins al moment al voltant dels aspectes psicosocials de la diabetis, i en el qual van participar pacients i professionals de la salut (metges de família, endocrinòlegs, infermeres i dietistes), va demostrar que el suport i l'atenció disponibles per satisfer les necessitats psicològiques i educatives de les persones amb diabetis i dels professionals era insuficient, tant en els països desenvolupats com en els que estan en vies de desenvolupament. Es va identificar la necessitat de millorar la comunicació entre pacients i professionals de la salut, promoure el treball en equip, fomentar la participació activa del pacient i ajudar-lo a superar les barreres per tal de millorar la gestió de la seva diabetis, així 
com també la necessitat de millorar l'atenció psicològica de les persones amb diabetis i de fomentar els models d'atenció centrats en la persona.

Malgrat que els sistemes d'atenció sanitària lluiten per incorporar aquests models d'atenció més centrats en la persona, l'impacte psicosocial de la malaltia encara no es gestiona de manera suficient. Cal aprofundir més en els problemes psicosocials, en el fet de saber quines són les necessitats no satisfetes dels pacients, les possibles barreres que en dificulten el compliment o aquelles situacions que poden afavorir o millorar la seva atenció. Al 2011, 17 països van participar en un segon estudi, el DAWN2 ${ }^{64,65,66}$, que va néixer amb la intenció de donar resposta a aquestes qüestions i que va incorporar familiars de les persones amb diabetis. Els resultats d'aquest estudi demostren que la diabetis segueix tenint un impacte negatiu en la vida de les persones afectades i en la de les seves famílies. A més, demostra que els professionals de la salut i les organitzacions sanitàries han de millorar molts aspectes de l'atenció al pacient i la família.

\subsubsection{La diabetis en les diferents etapes de la vida}

La DM és una malaltia que afecta individus de qualsevol edat. La resposta de la persona, les necessitats i la manera de viure la diabetis seran diferents segons les diferents etapes de la vida en la qual apareix la malaltia ${ }^{67}$. Vegem-ho:

\subsubsection{Etapa infantil}

Les necessitats d'un nen amb una malaltia crònica com la DM són les mateixes que les d'un nen sense DM, però la malaltia el pot fer sentir diferent. La família i l'escola tenen un paper molt important perquè aquesta diferència no es visqui com a negativa.

Tanmateix, els nens amb diabetis encara han de fer front a molts reptes i problemes a l'escola. A causa de la seva l'edat, poden tenir una capacitat limitada per controlar i tractar els seus nivells de sucre en sang i estar en risc de patir complicacions agudes. A més, se'ls pot negar l'accés a l'escola i a les activitats extraescolars, i poden estar sotmesos a estigmes i discriminacions i sentir-se tractats de manera diferent. Aquests factors els porten a l'absentisme, la depressió, l'estrès, el baix rendiment acadèmic i una mala qualitat de vida ${ }^{68}$. El grau en què els pares accepten la diabetis del fill i la capacitat de solucionar els problemes que es van plantejant en el dia a dia repercuteix en el control i l'adaptació que el nen va fent envers la diabetis. La màxima responsabilitat del control en aquesta etapa la tenen els pares i els educadors. 


\subsubsection{L'adolescència}

És una etapa complicada, de rebel-lia, contradiccions i inseguretats, amb un clar objectiu, el de ser autònom i independent. A més, hi ha una necessitat essencial de pertànyer a un grup i de fer tot allò que faci el grup encara que afecti el tractament i el control de la diabetis. Els professionals han de donar suport tant emocional com educatiu perquè el jove pugui superar aquells reptes que l'ajudaran a integrar-se en el grup, i tampoc no es pot oblidar els pares, que són els principals patidors dels canvis que repercuteixen en el control del seu fill.

Segons Wiebe ${ }^{69}$, els pares entreguen de sobte el control de la diabetis als fills durant l'adolescència, sense que hi hagi hagut una etapa de transició durant els anys anteriors. Es guien per l'edat del fill sense tenir en compte el seu desenvolupament emocional. El fet de no haver adquirit uns hàbits d'autocura contribueix a la poca adherència al tractament en aquesta etapa.

\subsubsection{Etapa adulta}

En aquesta etapa, que va dels 20-25 anys fins als 65 anys, el diagnòstic de diabetis pot suposar canvis en els àmbits laboral i familiar, i això pot generar ansietat, depressió i por. La negació de la malaltia és una actitud més freqüent que en altres etapes de la vida, però el fet de sentir-se part activa en la valoració de necessitats i del tractament, tot pactant objectius acordats, pot reduir el risc de negació de la DM64.

\subsubsection{Ancianitat}

Des d'un punt de vista sociocultural, un ancià és una persona de 65 anys o més. En aquest grup d'edat hi ha una gran variabilitat biològica, clínica i funcional, i, per tant, és molt difícil establir guies generals d'actuació, ja que no hi ha gaire evidència que permeti recomanar un determinat model de cures, atès que les persones grans amb DM2, fràgils, amb pluripatologia i discapacitat funcional se solen excloure dels estudis científics. Això fa que la decisió de tractament s'hagi de basar en la relació risc-benefici ${ }^{70}$ 


$$
2
$$




\section{MARC TEÒRIC}

La DM és el millor exemple de malaltia crònica vinculada a l'educació en el camp de la salut perquè, quasi com cap altre, requereix la implicació activa i decidida del pacient o la família per tal que les diferents estratègies terapèutiques siguin eficaces.

L'educació en el marc de les malalties cròniques com la diabetis s'ha d'entendre en relació amb el procés històric i cultural que ha seguit el concepte d'educació per la salut (EpS), ja que ha influït clarament en la manera d'abordar aquest problema de salut des d'un context sociosanitari, i també polític, atesa la seva magnitud. L’EpS integra els termes educació i salut, i la seva contextualització ha estat lligada a l'estructura política i social d'un país; per això, s'ha d'analitzar per separat la història de cadascun d'aquests termes per veure després com s'interrelacionen quan parlem d'EpS.

\subsection{Concepte de salut i la seva evolució}

La salut ha estat una de les principals preocupacions de les persones al llarg de la història i constitueix un valor social i cultural innegable. És un dels principals components que contribueixen al benestar, a la qualitat de vida de la població, al desenvolupament i a la riquesa d'un país ${ }^{71}$

Les diferents concepcions filosòfiques de la ment i el cos i la seva relació amb la malaltia en les diferents cultures, així com la gran diversitat d'enfocaments i perspectives en la construcció de la medicina com a ciència, juntament amb els canvis socials, han marcat de manera decisiva el significat de la medicina al llarg de la història, han determinat les pràctiques sanitàries de cada moment i han fet variar considerablement el significat dels conceptes de salut i malaltia.

El concepte de salut ha evolucionat amb el temps, des d'una noció més primitiva i una visió negativa en què la salut s'entenia com a absència de malaltia física, fins a un concepte actual, amb una visió positiva que abasta també el camp psicològic i social. Aquesta evolució dels conceptes de salut i malaltia ha estat marcada pels avenços polítics, socials i econòmics i també per les millores en els coneixements del procés salut-malaltia.

Tanmateix, la gran quantitat de definicions proposades per al terme salut evidencia la dificultat d'aconseguir un consens general, i fins i tot posa de manifest la relativitat del concepte.

Una de les primeres definicions de salut des d'una visió positiva va ser la de Sigerist (1941) qui la va definir així: «La salut no és simplement l'absència de malaltia, és quelcom positiu, una actitud joiosa i una acceptació alegre de les responsabilitats que la vida imposa a l'individu». 
En tot cas, la repercussió més important que ha tingut el concepte de salut va sorgir gràcies a la definició que en va fer l'OMS l'any 1946: « (...) un estat de complet benestar físic, mental i social i no solament com a l'absència de malaltia « ${ }^{73}$. Aquesta citació procedeix del Preàmbul de la Constitució de l'OMS, adoptada per la Conferència Sanitària Internacional, celebrada a Nova York el 1946 i que va entrar en vigor el 7 d'abril de 1948. Aquesta definició no ha estat modificada des de llavors ${ }^{74}$. El més innovador és que s'emmarca dins d'un concepte holístic, ja que considera la salut com un estat social i planteja un abordatge interdisciplinari, atès que es troba en l'àrea d'intersecció de diverses ciències, tant naturals com socials. En aquest sentit, la salut no és un fenomen exclusivament mèdic, sinó que és un tema que afecta tots els actors de la societat ${ }^{75}$.

En un sentit positiu, aquesta definició de salut va empènyer molts estats a adoptar mesures al voltant de les polítiques públiques sanitàries governamentals adreçades a millorar les condicions de vida dels ciutadans. Això va ser un pas molt important, però per molts autors aquest concepte de salut proposat per l'OMS tenia moltes limitacions ${ }^{76,77,78}$. La consideraven utòpica, estàtica i subjectiva: utòpica, perquè l'estat «complet» de salut o de malaltia no existeix, ja que no són condicions absolutes; estàtica, perquè considera la salut com un «estat», no com un procés dinàmic; i subjectiva, específicament, per la paraula benestar, ja que no es pot mesurar amb cap indicador i depèn del popi individu. El benestar es pot obtenir amb drogues o alcohol i el que beu o es droga no es pot dir que sigui una persona sana. La propaganda del benestar ha estat l'arma de dictadors, demagogs i persones que s'han aprofitat de la societat; per tant, el mot benestar no pot servir de paràmetre de salut ${ }^{75}$. D'alta banda, consideren que l'absència de malaltia és un concepte relatiu, ja que la salut no és una qüestió científica, sinó que varia d'una cultura a una altra, lligat també a interessos polítics i econòmics de qualsevol època o lloc determinat. Podríem dir que aquesta definició s'emmarca dins del model cartesià, que se sustenta en el paradigma biomèdic, un paradigma convencional i reduccionista.

Als anys setanta, el salubrista nord-americà Milton Terris ${ }^{79}$ va proposar una nova definició: "La salut és un estat de benestar físic, mental i social, amb capacitat de funcionament i no únicament l'absència de malestar o malaltia». Terris manté el concepte subjectiu d'estat de benestar i n'inclou un d'objectiu, que és el de capacitat de funcionament. Elimina la paraula complet, ja que entén que la salut no és un estat absolut, sinó que hi pot haver diferents graus de salut, i separa el terme malaltia del de malestar, ja que és possible que una persona estigui malalta però se senti bé. En un sentit crític, a Terris li va faltar treure la paraula estat, ja que s'oposa a l'essència canviant i dinàmica que té la salut.

L'any 1976, quan el model biomèdic d'atenció a la salut estava ja molt qüestionat i s'hi imposava el nou paradigma d'atenció des d'un model biopsicosocial, un grup de metges i biòlegs catalans ${ }^{75}$ va elaborar una nova definició de salut amb la intenció que correspongués a un model de realització humana, que servís a metges, sanitaris, sistema sanitari, pedagogs, sociòlegs, polítics, urbanistes..., és a dir, a tothom interessat per la promoció de l'home. Van definir salut com: «Aquella manera de viure que és autònoma, que és solidaria i que és joiosa», una definició utòpica, com admeten els mateixos autors, però menys que la de l'OMS. Es parla de 
la salut des d'una visió comportamental, i no com un estat sinó com un equilibri en el qual l'alegria, la solidaritat i l'autonomia són determinants que poden permetre que una persona, independentment de si pateix o no una malaltia, pugui tenir una bona salut; de tal manera que persones amb malalties agudes o cròniques puguin portar una vida saludable.

El 1985, l'Oficina Regional per a Europa de l'OMS ${ }^{80}$ va emetre una altra definició, que recollia el pensament actual i que considerava la salut com «la capacitat de realitzar les aspiracions i satisfer les necessitats, així com de respondre positivament als reptes de l'ambient»; hi subratIlen la gran importància que té l'entorn on ens movem en el nostre estat de salut i, per tant, en la nostra qualitat de vida. Entén l'home com una unitat biològico-psicològico-social, capaç de desenvolupar una sèrie d'habilitats personals que li faciliten poder escollir accions saludables i actuar sobre el seu entorn quan és necessari.

A aquest enfocament de relació amb l'entorn s'hi afegeix que la malaltia i la salut són també producte de la cultura, les creences, les normes i els valors que cada col-lectiu humà els atribueix. Aquest significat depèn de les condicions de vida de les poblacions i de les idees dominants de cada època. Per tant, l'abordatge dels problemes de salut s'ha de fer tenint en compte la perspectiva social i cultural. A més, si entenem el medi ambient com «el conjunt d'elements físics, biològics, econòmics, socials, culturals i estètics que interactuen amb l'individu i amb la comunitat en la qual viu, determinant la seva forma, caràcter, comportament i supervivència» ${ }^{81}$, la seva relació amb l'estat de salut és més que evident.

Relacionat amb això, l'OMS ${ }^{82}$ defineix així la salut ambiental: «Aquella disciplina que comprèn aspectes de la salut humana, inclosos la qualitat de vida i el benestar social, que són determinats per factors ambientals físics, químics, biològics, socials i psicosocials». També es refereix a la teoria i la pràctica d'avaluar, corregir, controlar i prevenir aquells factors en el medi ambient que potencialment poden afectar de manera adversa la salut de generacions presents i futures. Així mateix, l'OMS, a través de la Carta d'Otawa ${ }^{83}$ i la convenció de Yakarta ${ }^{84}$,va posar de manifest que per arribar a quotes adequades de salut s'ha de posar èmfasi en el control del medi ambient.

D'acord amb el concepte de salut com un dret humà fonamental, la Carta d'Otawa identifica determinats prerequisits per a la salut, que són la pau, recursos econòmics adequats, alimentació, educació, habitatge, un ecosistema estable, un ús sostenible dels recursos, justícia social i equitat. Una bona salut és la principal font de desenvolupament personal, econòmic i social i una dimensió important de la qualitat de vida. Tots els factors socials, polítics, econòmics, culturals, ambientals, comportamentals i biològics poden afavorir o perjudicar la salut. Reconèixer aquests prerequisits palesa l'estreta relació que existeix entre les condicions socials i econòmiques, l'entorn físic i l'estil de vida individual i la salut.

Segons Dubos $(1965)^{85}$, el concepte actual de salut s'explica des d'un procés adaptatiu dinàmic de l'home al medi natural, cultural i socioeconòmic que l'envolta, el qual està condicionat per múltiples factors que influeixen en l'estat de salut i que anomenem determinants de la salut. 


\subsubsection{Determinants de la salut}

El Glossari de Promoció de la Salud ${ }^{86}$ defineix els determinats de la salut com «el conjunt de factors socials, personals, econòmics i ambientals que determinen l'estat de salut de les persones i de les poblacions». La relació que hi ha entre l'entorn i la salut es coneix des de l'antiguitat. Hipòcrates (430-370 aC) ja va descriure la relació entre l'ambient i la malaltia en el seu tractat Sobre els aires, les aigües i els llocs, on dona gran importància al clima, la qualitat de les aigües, l'alimentació i els costums de les persones com a generadors de malaltia ${ }^{87}$. Més tard va aparèixer una altra figura rellevant, Galè (130-200 dC), que va dividir les causes productores de malaltia en externes (trastorns alimentaris, sexuals o emocionals, excés de treball, calor, fred, etc.), internes (edat, sexe, constitució, etc.) i conjuntes o immediates (que serien el resultat de l'acció de les primeres sobre les segones). Com podem veure, Galè va incloure el descans, els sentiments i les passions com a elements també directament implicats en una bona salut $\mathrm{i}$ va relacionar per primer cop estils de vida i salut ${ }^{88}$. A finals del segle XVII, Johann Peter Frank ${ }^{89}$ descriu una sèrie de determinants que ajudarien a la conservació o la pèrdua de la salut. Va afirmar que «la misèria del poble és la causa de la malaltia», i va destacar el paper de la pobresa com a causa central de la malaltia, afirmació que l'Assemblea de l'OMS va subscriure el 1969, quan va assenyalar que «la incultura i la pobresa són les principals causes de malaltia» ${ }^{90}$.

Durant els anys setanta van aparèixer diversos models que intenten explicar la producció o pèrdua de salut i els seus determinants. Hi destaca el model holístic de Lafranboise $(1973)^{91}$

L'esquema de Lafranboise va ser desenvolupat per Marc Lalonde el 1974, secretari de Salut i Benestar del Canadà, a l'informe «Noves perspectives de salut en els canadencs»" distribueix els determinants de salut en quatre grups de factors:

Factors relacionats amb la biologia humana (genètica, envelliment, herència)

1. Medi ambient físic i social (pobresa, contaminació)

2. Estils de vida (exercici, alimentació, consum de tabac i alcohol, estrès)

3. Sistemes d'assistència sanitària (cobertura, qualitat)

Actualment es considera que gairebé tots els factors que integren els determinants de la salut són modificables. Alguns de relacionats amb la biologia humana que l'any 1974 no s'hi consideraven, avui es poden modificar gràcies als nous descobriments genètics i diagnòstics i a les teràpies basades en la biotecnologia. Els factors que constitueixen el grups 2 i 3 de vegades són difícilment separables, ja que hi ha una clara relació entre la classe social i la presentació de diferents malalties, hàbits i factors de risc. Respecte al quart grup de determinants, inclou la mala organització de les cures d'infermeria, la mala praxis mèdica, i el mal l'ús i l'abús dels medicaments, entre d'altres, com a factors productors de malaltia. L'avaluació d'aquest model va demostrar que les malalties causades pels estils de vida no saludables ocasionaven un elevat 
cost econòmic al sistema sanitari. Com a conseqüència, hi va haver un canvi de pensament iniciat al Canadà, després als EUA i posteriorment a Europa, que va donar lloc a un canvi de prioritats de salut pública que va dur a destinar un alt percentatge de recursos a la prevenció i l'educació sanitària. Malgrat això, aquest model va estar discutit, ja que va focalitzar la promoció de la salut en els estils de vida, considerant-los com una decisió individual, i no tenia en compte els factors socials que determinen els hàbits de les persones ${ }^{93.94}$

Va ser a partir dels estudis que es van fer els anys noranta sobre la definició i la valoració de les condicions socioeconòmiques, la cultura, l'educació, l'equitat, l'accés a l'atenció de salut, les polítiques socials i d'altres que va sorgir un nou model de determinants de salut, els coneguts com a determinants socials de la salut. Aquest nou model, de Dahlgren i Witehead ${ }^{95}$ (1991), es pot representar com una sèrie d'estrats concèntrics (figura 1) en què a la base es troben les característiques individuals de les persones, com ara l'edat, el sexe i altres factors constitucionals que es consideren no modificables. Al seu voltant hi ha un conjunt d'accions que són modificables per l'acció política. En primer lloc, se situen els estils de vida individuals; en segon, la interacció dels individus entre ells mateixos i amb l'entorn per mitjà de les xarxes socials i comunitàries; dins el tercer nivell se situen les condicions de vida i de treball, l'accés als béns fonamentals com l'educació i l'assistència sanitària; i en el quart nivell, les influències econòmiques, culturals i ambientals que afecten totes les altres capes.

A l'informe de la Comissió de determinants socials de la salut de l'OMS ${ }^{96} s^{\prime}$ hi defineixen aquests determinants com aquelles circumstàncies en què les persones neixen, creixen, viuen, treballen i envelleixen, inclòs el sistema de salut, que són el resultat de la distribució dels diners, el poder i els recursos a escala mundial, nacional i local.

L'evidència de la importància dels determinants socials converteix la salut en un assumpte col-lectiu. Des d'aquest punt de vista, es pot subscriure que tot i que els serveis mèdics poden millorar la salut, aquesta no és conseqüència de la medicina, sinó dels seus determinants, entre els quals, els serveis de salut. A més, els serveis de salut han de reorientar-se per incorporar les dimensions col-lectives de salut i dirigir les actuacions als determinants modificables dins del seu àmbit de responsabilitat. Això implica canvis en tots els serveis de salut, incloent-hi la coordinació de l'atenció primària i hospitalària, la coordinació intersectorial, el foment del treball interdisciplinari i la modificació de l'enfocament de l'atenció cap a un model biopsicosocial. 


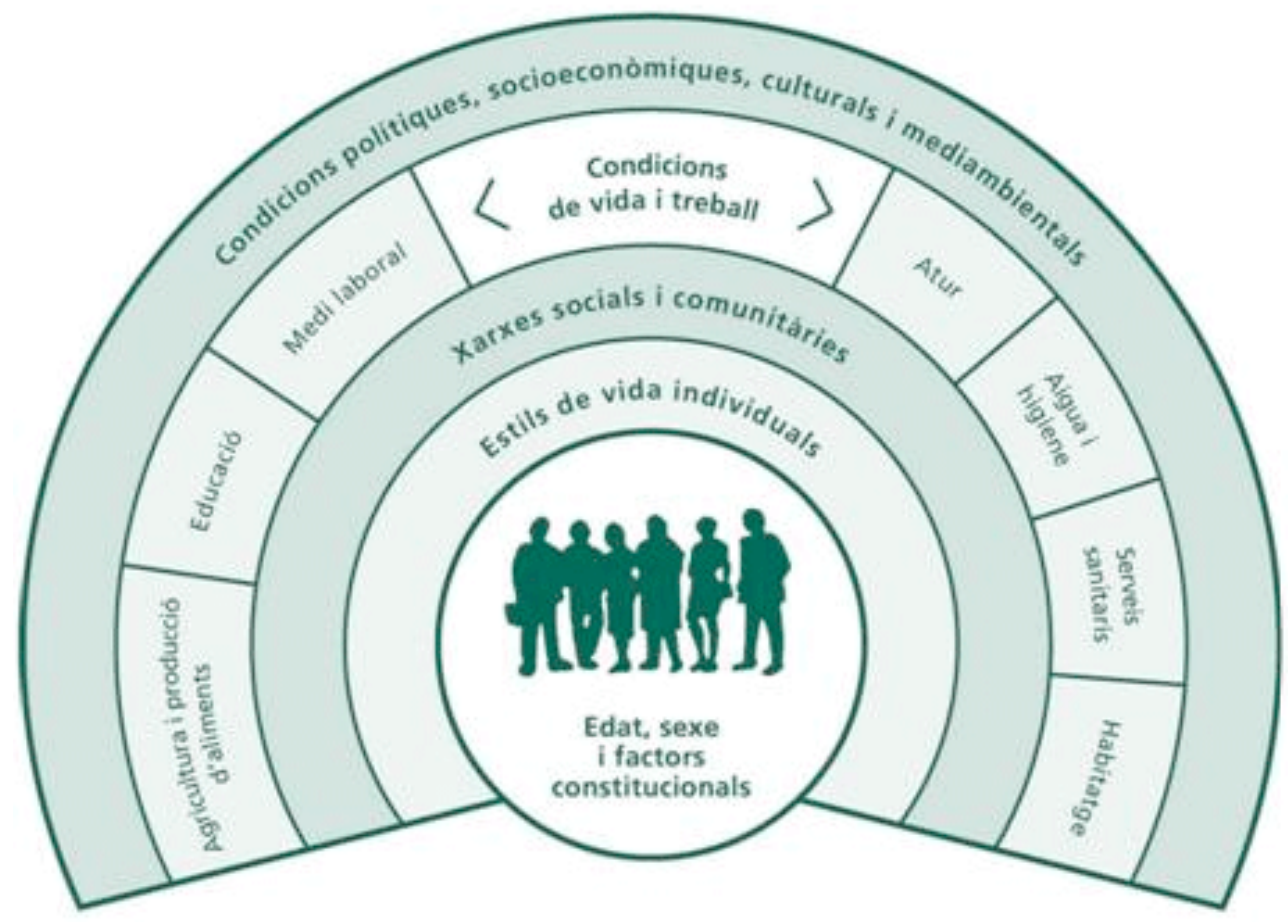

Figura 1. Model de determinants de la salut. Modificat de Dahlgren i Witehead per a l'Informe de Salut de Barcelona (2003)

Font: Pla de Salut Comunitària i Promoció de la Salut de Barcelona

\subsubsection{Del model biomèdic al model biopsicosocial d'atenció a la salut. Aten- ció centrada en el pacient}

El model biomèdic es va instituir a alguns països europeus a finals del segle XVIII i principis del segle XIX, i al països americans a finals del segle XIX, durant la Primera Revolució Industrial. Les bases d'aquest model es troben en els avenços de la biologia i en el descobriment de les bactèries com a causa de les malalties infeccioses. Defineix la malaltia com una alteració fisiopatològica resultant de lesions, alteracions bioquímiques o infeccions i no concep la possibilitat de qualsevol alteració psicològica o social. És un model d'atenció sanitària que respon a interpretacions clíniques i biològiques del fenomen i la problemàtica en salut. Dona valor al mecanisme etiopatogènic subjacent a les malalties i promou l'abordatge semiològic i terapèutic dels signes i els símptomes. S'observa, en aquest concepte, una orientació curativa i individualista ${ }^{97}$.

El model biomèdic, que encara s'utilitza tant per diagnosticar com per tractar una malaltia, comporta una pèrdua d'autonomia de l'individu i també de la colllectivitat, cedeix el protagonisme als professionals que dominen la tecnologia biomèdica i converteix els pacients en éssers dependents dels serveis de salut. La relació professional entre la salut i el pacient és 
asimètrica, i exclou el coneixement del pacient sobre la malaltia, les seves creences i referències socioculturals ${ }^{98}$.

Històricament, aquest model ha influït intensament en la infermeria buscant un estatus similar al saber mèdic $i$, per tant, va basar els seus coneixements en accions de curació de la malaltia i la va fer més dependent de paràmetres biològics, raó per la qual sovint va generar una medicalització de les cures ${ }^{99}$.

No obstant, al llarg del segle xx els grans canvis produïts en la política, l'economia i la cultura van contribuir a millorar les condicions de vida, la salut pública i la nutrició. L'ús dels antibiòtics i de les vacunes va permetre el control de les malalties infeccioses, però va aparèixer o augmentar un seguit de malalties cròniques, moltes associades a factors ambientals i als estils de vida de les persones (OMS, 1986), com és el cas de la DM. Es veia necessari un canvi de paradigma que expliqués per què el cos humà exposat a agents externs uns cops provocava malaltia i altres no. Sense negar en cap moment la biologia, hi va haver una inquietud per intentar veure la relació que existia entre els fenòmens biològics i els socials. El model biomèdic resultava insuficient per explicar i comprendre la complexitat del procés salut-malaltia, i entre els anys seixanta i setanta es va evidenciar una pèrdua d'eficàcia d'aquest model, bàsicament perquè̀ ${ }^{97}$ :

- Negava la subjectivitat del pacient

- Se centrava en les activitats curatives

- Emfatitzava les activitats assistencials

- Negava les accions preventives

Engel (1977) ${ }^{100}$ va postular la necessitat d'un model mèdic holístic, al qual va anomenar biopsicosocial, que es presenta com un nou paradigma en la medicina. Aquest model aposta per donar la paraula al pacient, el qual passa de ser un actor passiu en la relació metge-pacient (model biomèdic) a esdevenir el subjecte de l'atenció clínica. Engel creia que tots els fenòmens relatius a la salut integraven aspectes no només biològics, sinó també psicològics i socials. Posa com a exemple que si una malaltia somàtica com la DM es tracta segons un model biomèdic, en el qual s'exclouen els factors psicosocials, es produeix una clara interferència en el tractament. Un defecte bioquímic no sempre defineix el que representa la totalitat de la malaltia. Per a una comprensió completa, calen conceptes i marcs de referència. Per tant, mentre que el diagnòstic de la DM es fa en base a una sèrie de manifestacions clíniques que hauran de ser comprovades amb tècniques de laboratori, la manera com aquests símptomes són experimentats i manifestats per cadascun dels pacients i com els afecten requereix de la consideració de factors psicològics, socials i culturals.

A fi d'establir una relació entre els processos bioquímics i les manifestacions clíniques de la malaltia, cal un enfocament científicament racional de dades psicològiques i comportamentals 
dels pacients, ja que aquestes tenen relació amb els termes que utilitzen per manifestar els fenòmens clínics que estan experimentant. Segons Engel, és fonamental que els professionals tinguin un bon nivell pel que fa a habilitats en tècniques de comunicació i suficients coneixements sobre els determinants psicològics, socials i culturals per tal d'entendre les diferents maneres en què els pacients comuniquen els símptomes de la malaltia.

La forma com cada persona s'adapta als canvis que comporta la malaltia, la manera com una persona pot ser vista pels altres com un malalt i accepta entrar en el sistema sanitari com a pacient, les discrepàncies entre l'intent de correcció de les variables biològiques i els resultats del tractament, són clarament factors psicològics i socials que només poden ser abordats des d’un model que vegi la persona des d'una mirada holística.

El model d'atenció a l'individu orientat a la modificació dels determinats socials de salut es basa en el model biopsicosocial, que en la pràctica clínica ha conduït al mètode d'atenció centrat en el pacient, per introduir-hi les seves vivències, a més de les seves preferències i necessitats en el procés diagnòstic i terapèutic per tal d'orientar el diagnòstic dels problemes i les estratègies d'intervenció ${ }^{101}$. Aquest model, contextualitzat a l'escola de Canadà de McWhinney, és un mètode d'atenció que considera de manera simultània l'agenda del professional i la del pacient. La idea és diagnosticar i tractar una malaltia de forma teòrica, atenent els símptomes (disease), i alhora el pacient mira d'alleujar el seu malestar (illness) d'acord amb els seus valors, preferències, creences, etc. La malaltia s'explora de forma clàssica (símptomes, cronologia, signes) i el malestar s'explora a través del coneixement dels sentiments del pacient, de les seves creences, de l'impacte que tenen els símptomes en la seva vida i les seves expectatives ${ }^{102}$.

Quan una persona pateix una malaltia, no es preocupa d'aspectes de gestió sanitària com la productivitat, els objectius sanitaris o la relació cost-efectivitat, sinó de la seva pròpia situació. Cada individu experimenta i afronta els problemes de salut a la seva manera en el marc de les circumstancies particulars de la seva vida ${ }^{103}$. Les persones desitgen que el professional entengui el seu cas, el seu sofriment i els problemes que està afrontant, i els professionals de la salut han de saber moure's en aquesta diversitat, han d'entendre les persones de manera holística: els seus problemes físics, emocionals i socials, el seu passat, el seu futur i les seves creences. Sense una perspectiva global de la persona immersa en un context familiar i comunitari, es perden de vista aspectes clau de la salut que a simple vista estarien fora de les diferents categories de malaltia. La resposta a un problema de salut, en general, serà més eficaç si el professional està preparat i entén les seves diferents dimensions ${ }^{104}$. Alguns estudis mostren que pocs professionals estan preparats per dispensar una atenció centrada en la persona, ja que no tenen prou habilitats per identificar i avaluar els problemes psicosocials dels pacients ${ }^{105,106}$. 


\subsection{Concepte d'educació}

La paraula educació ha estat utilitzada en un sentit molt ampli per designar el conjunt d'influències que la natura o els homes poden exercir sobre la nostra intel-ligència o sobre la nostra voluntat. L'acte educatiu és necessari i inherent a la naturalesa humana. A través de l'educació no solament podem transmetre el coneixement (el saber), sinó també les capacitats per al «saber fer» L'educació no només es produeix mitjançant la paraula, sinó que també està present en les nostres accions, sentiments i actituds, i afavoreix el procés de maduració de la persona ${ }^{107}$.

Gràcies a l'educació s'adquireixen habilitats, actituds i valors que produeixen canvis en la persona, i que són de caràcter emocional, social o intel·lectual. El procés d'educar és un procés de socialització i desenvolupament que tendeix a aconseguir la capacitació de l'individu per moure's en el seu medi i a facilitar-li les eines per a la gestió de la seva pròpia realitat i per a la participació activa en els diferents escenaris de la societat.

L'educació ha variat moltíssim al llarg del temps, segons els països i les cultures. A les ciutats gregues i llatines l'educació ensenyava l'individu a subordinar-se cegament a la col-lectivitat, a convertir-se en esclau de la societat. Actualment, s'esforça per convertir l'individu en una personalitat autònoma ${ }^{108}$.

Segons la majoria d'experts, l'expressió llatina educatio prové de dos verbs: educare i educere. Educare vol dir formar, conduir, instruir o alimentar, i educere significa anar cap a fora, sortir, extreure, conduir, treure de l'obscuritat, potenciar. Aplicades aquestes accions a les persones, podem veure que l'infinitiu educere es refereix a les potencialitats específiques de l'espècie humana, el saber, la voluntat, la intel-ligència o la sensibilitat, presents virtualment en cada persona des de la seva concepció, mentre que l'acció pròpia d'educare és la de facilitar les condicions ambientals, socials i culturals bàsiques perquè aquestes virtualitats subjectives puguin iniciar i expandir la seva potencialització ${ }^{109}$. Des d'aquesta perspectiva, hi ha dos models ben diferenciats d'educació:

\section{- Educació tradicional}

Fa referència a la veu educare. És un model d'educació unidireccional i asimètric. La formació dels alumnes està centrada en l'ensenyança i l'objectiu principal és la transmissió de continguts. El professor és el centre del procés, el que té el coneixement, i l'alumne té un rol passiu, ha d'escoltar, assimilar i repetir. S'entén l'alumne com un receptacle buit que, per tant, l'educador ha d'omplir demostrant autoritat.

És un model que ha estat especialment criticat perquè no implica activament l'alumne i no l'estimula a adoptar reptes de nivell superior. 


\section{- Educació interactiva}

Fa referència a la veu educere. A diferència del model anterior, la formació dels alumnes se centra en l'aprenentatge, i l'objectiu principal no és transmetre continguts, sinó capacitar I'individu perquè integri el saber, el saber fer, el saber ser i el saber estar. Aquest conjunt de sabers integren el que anomenem competència ${ }^{110}$.

És un model actiu en el qual l'alumne és crític amb la realitat sociocultural que l'envolta. El professor adopta el rol d'orientador i mediador de l'aprenentatge, i dissenya experiències educatives que involucren l'alumne i el fan participar de manera activa en el procés d'ensenyança-aprenentatge, cosa que afavoreix un aprenentatge significatiu. El més important no és memoritzar continguts, sinó reflexionar, dubtar i crear el propi coneixement. Es tenen en compte com a punt de partida les necessitats socioculturals, espirituals i tècniques de l'alumne ${ }^{111}$.

\subsubsection{Educació sanitària / Educació per a la salut}

L'educació és un factor determinant en la salut. L'expressió educació sanitària neix a finals del segle XIX com una necessitat d'anomenar d'alguna manera aquelles pràctiques d'informació sanitària que es començaven a dur a terme com a conseqüència dels progressos en la bacteriologia ${ }^{112}$.

\subsubsection{Definicions}

Els conceptes d'educació sanitària i educació per a la salut (EpS) expressen el mateix objectiu: millorar la salut individual i col·lectiva incidint no solament en l'individu, sinó també en el seu entorn social i cultural ${ }^{112}$.

A l'hora d'establir una definició d'educació sanitària o EpS ens trobem amb verdaders problemes, perquè existeixen tantes definicions com autors o organismes han provat de fer-ho, cosa que fa difícil consensuar-la.

Quan s'analitzen les diferents definicions que s'han proposat al llarg del temps, veiem que totes tenen un objectiu comú: la modificació en sentit favorable de coneixements, actituds i comportaments de salut dels individus i les comunitats, de tal manera que els coneixements i les actituds estan plantejades com un vehicle per a la modificació de comportaments insans. D’altra banda, podem observar importants diferències entre unes definicions i altres en la forma d'assolir els canvis de comportaments (accions sobre els individus, sobre la comunitat, sobre el medi ambient, etc.). Finalment, com a conseqüència del desenvolupament de la salut comunitària, es va incloure dins de les funcions de l'EpS la capacitació dels individus i els grups en els serveis de promoció i restauració de la salut ${ }^{113}$. 
Vegem ara algunes definicions d'educació sanitària. Una de les primeres definicions acceptades va ser la de Wood (1926), que la va descriure com «la suma d'experiències que influeixen favorablement sobre els coneixements, actituds i hàbits relacionats amb la salut de l'individu i comunitat» ${ }^{113}$.

Per Derribery (1943), l'educació sanitària és «un procés d'aprenentatge dirigit a modificar de manera favorable les actituds i a influir en els hàbits higiènics de la població $»^{113}$.

Aquestes dues definicions coincideixen a destacar els hàbits i les actituds de les persones com els aspectes primordials que s'interrelacionen amb la salut; no obstant, es poden considerar reduccionistes, ja que no tenen en compte els factors socials o econòmics com a elements que afecten de manera gaire considerable els individus o la societat.

Gilbert (1959), considerat com un dels noms més importants en matèria d'EpS al Canadà, l'entén com «instruir les persones en matèria d'higiene, de forma que apliquin els coneixements adquirits al perfeccionament de la seva salut» ${ }^{113}$.

L'OMS, el 1969, la va definir com: «Induir les persones a adoptar i mantenir els costums d'una vida sana, utilitzar adequadament els serveis sanitaris que té a la seva disposició i prendre decisions individualment i col-lectivament per millorar el seu estat de salut i el del medi en què habiten ${ }^{114}$.

Alejandro Seppilli (1970), fundador de l'Escola Italiana d’Educació Sanitària de la Universitat de Perugia, diu que és «una intervenció dirigida a responsabilitzar els grups socials i els individus d'un canvi conscient i permanent d'actituds relacionades amb la salut $»^{115}$.

En totes aquestes definicions, considerades clàssiques, el concepte d'educació sanitària es fonamenta en el model biomèdic. Inicialment, només s'incloïen accions educatives adreçades a l'individu que tendien a responsabilitzar-lo de la seva pròpia salut, amb l'objectiu de modificar conductes insanes. Les activitats eren informatives, prescriptives i puntuals, i la informació era transmesa de forma unidireccional. En aquest cas, són els professionals de la salut els únics que tenen els coneixements necessaris per tenir cura de la salut i per decidir quins són els que els individus han d'adquirir i complir amb precisió. Més tard sorgeix la preocupació de la medicina per la conducta de les persones i les seves conseqüències en la salut, i es parla d'EpS basada en el comportament. S'entén l'EpS com una sèrie d'intervencions destinades a facilitar canvis en la conducta i en els estils de vida a fi d'aconseguir comportaments saludables, partint de la idea que el comportament d'una persona pot ser la causa principal d'un problema de salut, però també pot ser la seva solució. Modificant el seu comportament, moltes persones poden prevenir o resoldre molts dels seus problemes de salut ${ }^{116}$.

A mitjans de la dècada dels setanta, el concepte va sofrir un canvi com a conseqüència d'una sèrie d'investigacions en l'àmbit de la psicologia, medicina social i conductual, que van demostrar que les conductes humanes no depenen únicament de factors interns de l'individu, 
sinó també de factors externs, ambientals i socials (model biopsicosocial). També s'havia demostrat que les accions educatives dirigides només a l'individu havien estat poc eficaces a l'hora de modificar comportaments molt arrelats en la societat. Per tant, es va considerar que les accions educatives havien de promoure canvis en aquests àmbits. Sorgeix, així, una visió d’EpS participativa, crítica i emancipadora. L'objecte d'intervenció ja no és la conducta, sinó l'estructura social, que és on es troba el «teixit causal» dels patrons de morbimortalitat.

Potser la definició més completa d'EpS, que té en compte tots aquests aspectes, és la que va proposar el IV Grup de Treball de la «National Conference on Preventive Medicine», que estableix que «l'educació sanitària ha de ser un procés que informi, motivi i ajudi la població a adoptar i mantenir pràctiques i estils de vida saludables, propugni els canvis ambientals necessaris per facilitar aquests objectius i dirigeixi la formació professional i la investigació envers aquests mateixos objectius» ${ }^{113}$.

\subsubsection{Models d'educació per la salut}

Un model educatiu és com «un pla o patró que es pot utilitzar per donar forma als plans d'estudi, per dissenyar materials d'ensenyament i per guiar la instrucció a l'aula i a altres medis». Els models educatius orienten els docents en l'elaboració dels programes d'estudis i en la sistematització del procés d'ensenyança-aprenentatge; per això, els models d'ensenyança són també models d'aprenentatge, perquè no es poden separar dos models d'un mateix procés. Aquests models varien d'acord amb el període històric, ja que la seva vigència i utilitat depenen del context sociall17.

En funció dels objectius i l'enfocament metodològic de les activitats i de la ideologia subjacent, es distingeixen diferents models conceptuals en educació. Tot i que existeixen diferents classificacions, en diferenciarem quatre models $^{118}$ :

\section{- Model informatiu}

Es fonamenta en el model biomèdic i en l'educació tradicional. Es tracta d'un model preceptiu i autoritari. Els usuaris han de complir les normes prescrites pels professionals sanitaris, que són els únics que se suposa que tenen el coneixement sobre la salut. No valora l'autoresponsabilitat en matèria de salut. Prioritza la prevenció i actua sobre l'individu sense considerar els factors socioculturals i ambientals. Tot i que és el model més criticat, també és el més utilitzat.

\section{- Model persuasiu-motivacional}

Neix a finals de la dècada del seixanta com una crítica al model informatiu. Es basa en la necessitat de modificar hàbits insans i en la recerca de tècniques per motivar o produir canvis conductuals. Inclou l'aportació de la psicologia i d'altres ciències socials: pedagogia, 
antropologia, sociologia, etc. Des d'aquestes ciències s'han definit moltes teories sobre la forma com s'originen els comportaments i per què es modifiquen, tot i que cap ha aconseguit demostrar una total eficàcia i efectivitat.

Aquest model, a diferència del model informatiu, té en compte els aspectes socioculturals, però els utilitza com a instrument per motivar i arribar millor per mitjà de missatges persuasius, per la qual cosa segueix sent un model preceptiu que atorga la iniciativa a l'educador.

\section{- Model radical}

Si els models anteriors se centraven en els individus, aquest ho fa fonamentalment en els factors socioeconòmics i culturals que influeixen en la salut i la malaltia. A més, disminueix la càrrega de responsabilitat individual, ja que s'ha comprovat que les intervencions basades en la conducta tenen un impacte reduït i limitat en les persones més motivades i instruïdes.

El seu objectiu és disminuir les desigualtats socials modificant les estructures socioeconòmiques. Només si les persones tinguessin els mateixos recursos per a la salut seria just incidir en la responsabilitat individual. És imprescindible la participació comunitària, ja que cal desenvolupar una consciència social capaç d'investigar totes les forces sociopolítiques i econòmiques que configuren el medi ambient i que influeixen en el procés de salut i malaltia.

\section{- Model orientat a la capacitació}

Davant la ineficàcia dels models d'EpS centrats en els individus, i atesa la importància de dur a terme una revolució social, actualment es tendeix a un model que integri el millor de cadascun i tingui en compte la influència dels aspectes socioeconòmics i culturals en la salut. Del model informatiu s'extreu la importància d'una informació objectiva i veraç basada en l'evidència científica i que doti les persones d'una actitud crítica i les capaciti per prendre decisions informades. Del model persuasiu s'agafa el valor de la motivació per aconseguir un canvi d'actituds, basada en reforços positius i sense utilitzar la coacció o la por. I del model radical es considera la rellevància dels factors socioeconòmics i culturals i la necessitat d'un treball interdisciplinari capaç d'abordar totes les variables que influeixen en la salut individual i col-lectiva.

L'objectiu d'aquest model és capacitar les persones perquè siguin autosuficients en relació amb la seva salut. Diferencia clarament entre informar o formar i fomenta la participació activa de la persona. 


\subsubsection{El paper de l'educació en el tractament de la diabetis. Perspectiva històrica i tendències actuals}

La DM és l'exemple més clar de malaltia crònica de tractament complexa en la qual el pacient té la màxima responsabilitat ${ }^{58}$. Els pacients, especialment els que tenen $\mathrm{DM} 2$, sovint han de prendre una notable quantitat de medicació oral per la pròpia DM i per les comorbilitats associades, han d'aprendre tècniques noves com l'administració d'insulina i el control de la glicèmia capil·lar, i han de modificar en més o menys grau una sèrie d'hàbits com l'alimentació, la higiene, la pràctica d'exercici o deixar el tabac. Els que tenen DM1, per poder controlar-la millor, han d'aprendre fórmules complexes per comptar les racions de carbohidrats de cada àpat i ajustar les dosis d'insulina en relació amb aquestes racions, al control glucèmic i a l'exercici.

Tots els aspectes terapèutics descrits també interactuen amb la manera com cada persona afronta la malaltia, les emocions individuals, l'ambient professional, familiar i social, entre d'altres. Moltes persones han de fer front a problemes relacionats amb les complicacions, les quals poden reduir dràsticament les activitats professionals o socials i afavorir processos de depressió, un aspecte que contribueix a empitjorar el control de la malaltia ${ }^{119}$.

Com que els resultats del control de la DM estan estretament relacionats amb les decisions terapèutiques que el pacient o la família prenen en el dia a dia, l'èxit del tractament depèn del coneixement, la capacitat i l'habilitat del pacient per adoptar els comportaments d'autocura descrits; és a dir, canviar el seu estil de vida, mantenir-lo en el temps prenent part activa a identificar, resoldre o buscar ajuda per solucionar els problemes que van sorgint al llarg del temps. Per a l'adquisició de coneixements i el desenvolupament d'aquestes habilitats és imprescindible proporcionar una educació de qualitat al pacient i/o a la família, de manera continuada, que s'adapti a les seves necessitats i que estigui impartida per professionals sanitaris ben preparats ${ }^{120}$. Les persones amb DM que no reben educació estan menys capacitades per adoptar decisions documentades, fer canvis conductuals, resoldre els problemes psicosocials que presenta la DM i, per tant, podrien veure's incapacitats per controlar la seva DM de forma eficaç. A més, l'educació del pacient i/o la família és la clau per prevenir les complicacions i mantenir una qualitat de vida adequada.

Educar els pacients no vol dir incrementar els seus coneixements sobre la malaltia, sinó fer-los conscients dels seu problema i ajudar-los a gestionar millor el tractament per poder adaptar el control de la DM als constants canvis de la vida quotidiana ${ }^{121}$. L'educació del pacient és un procés complex i, com hem vist, hi ha molts factors que poden intervenir en la comprensió dels canvis que ha de realitzar, com ara l'edat, el nivell socioeconòmic i cultural i els aspectes psicològics i d'adaptació a la malaltia ${ }^{122}$. L'efectivitat de l'educació també depèn de l'existència o no de suport familiar, la relació amb l'equip terapèutic o les creences i actituds respecte de la malaltia ${ }^{123}$.

Per a una atenció de qualitat, els professionals de la salut no només han d'incorporar a la seva praxis els avenços en el tractament biomèdic, sinó també tots aquells altres relacionats 
amb la manera d'ajudar els pacients a posar-los en acción ${ }^{120}$. Les estratègies desenvolupades per atendre la DM des d'una perspectiva global combinant elements biomèdics, psicosocials i educatius representen un model terapèutic exemplar per al tractament de la majoria de malalties cròniques, i específicament la DM ${ }^{124,125}$.

Aquest tipus d'educació, anomenada educació terapèutica, perquè forma part ineludible del tractament, és un dret que tenen tots els pacients i un deure de tots els professionals implicats en el tractament de la malaltia dels diferents nivells assistencials.

\subsubsection{Què entenem per educació terapèutica?}

Al llarg dels anys ha canviat la definició d'educació a les persones diabètiques i a les seves famílies. Als anys vuitanta, amb el desenvolupament dels programes d'educació sanitària i la promoció de la salut s'anomenava educació sanitària aplicada a la diabetis, o també educació diabetològica. Actualment, a Europa s'utilitza l'expressió educació terapèutica a la diabetis (ETD), o, en anglès, diabetes therapeutic education (DTE), introduït per un grup d'experts liderat pel prof. Jean Philippe Assal el 1998 a petició de l'OMS, i que no només s'aplica a la DM sinó també a l'educació en altres malalties cròniques ${ }^{126}$. Als EUA s'utilitza el terme educació per a l'autogestió de la diabetis, o, en anglès, diabetes self-management education (DSME), i més recentment han introduït la paraula suport, definint el terme com a diabetes self-management education and support (DSME/S)»127, donada la importància del suport continu per a les persones amb DM i les que tenen risc de desenvolupar-la, sobretot per fomentar el canvi de comportament, per mantenir conductes saludables relacionades amb la DM i per abordar els problemes psicosocials.

Les definicions de cadascun d'aquests termes són les següents:

- Educació terapèutica en la diabetis (therapeutic patient education, OMS, 1998)

És un procés continu i part integral de l’atenció centrada en la persona. Inclou la sensibilització, la informació, l'educació per a l'aprenentatge de l'autogestió i el suport psicosocial en les diferents situacions relacionades amb la malaltia i el tractament. L'objectiu és ajudar els pacients i les seves famílies a:

- Desenvolupar la capacitat d'autogestió del tractament per prevenir complicacions.

- Cooperar amb els equips de salut.

- Poder viure mantenint o millorant la qualitat de vida. 
- Educació per a l'autogestió de la diabetis (diabetes self-management education and support -DSME/S-, ADA, 2012)

És un procés continu que facilita coneixements, habilitats i actituds per a l'autogestió de la DM. Aquest procés incorpora les necessitats, els valors i les experiències de vida de les persones amb DM i ha d'estar guiat per una atenció basada en l'evidència. Els objectius són:

- Donar suport informat a la presa de decisions.

- Facilitar l'adherència a l'autogestió del tractament.

- Facilitar la resolució de problemes i la col-laboració activa amb els professionals de la salut per tal de millorar els resultats clínics, l'estat de salut i la percepció de qualitat de vida ${ }^{127}$.

\subsubsection{Perspectiva històrica i actual de l'educació terapèutica en la diabetis}

Des d'una perspectiva històrica, Bouchardat ${ }^{1}$, el 1875, abans del descobriment de la insulina, feia referència a l'educació del pacient com a part fonamental del tractament de la DM, especialment pel que fa a la necessitat que la persona diabètica entengués el seu règim alimentari i d'exercici' ${ }^{128}$. Però podem considerar que l'educació de les persones amb DM s'inicia amb el descobriment de la insulina l'any 1921, quan es comença a administrar als pacients. És llavors quan les persones amb DM1 ja poden sobreviure a la seva malaltia i els professionals poden oferir els mitjans als pacients per poder viure amb DM. A partir d'aquell moment, alguns diabetòlegs van començar a educar els seus pacients.

El Dr. Joslin ${ }^{129}$, fundador de la clínica Joslin a Boston, va ser un gran defensor de la importància d'educar el pacient i la seva família i de la idea que el tractament de la DM requereix d'un equip interdisciplinari, concepte de gran importància actualment. Va ser un mestre apassionat, dedicat a educar els pacients i les famílies, així com els metges i altres professionals de la salut. Els conceptes que el Dr. Joslin va desenvolupar sobre l'educació foren una experiència única fins al final de la Segona Guerra Mundial.

A Europa, altres diabetòlegs carismàtics i deixebles del Dr. Joslin que van creure en la idea que la persona amb DM havia de participar de forma activa en l'autogestió del seu tractament, com és aprendre a injectar-se la insulina i seguir una alimentació adient, van ser: el Dr. Roma, a Portugal; el Dr. Lawrence, a Anglaterra, el Dr. Silvestro Silvestri, a Itàlia, o el Dr. Carrasco i

1 Apollinaire Bouchardat, farmacèutic francès a qui es considera com el fundador de la diabetologia. Fou la persona més important en desenvolupar la teràpia dietètica pel tractament de la diabetis abans del descobriment de la insulina, va reconèixer que el dejuni era un mètode per reduir la glucosuria i va contemplar la possibilitat de que la causa principal de la diabetis es troba en el pàncrees. A més, va subratllar la importància de l'exercici en el tractament i va desenvolupar un mètode d'autocontrol urinari per detectar la presència de glucosa. 
Formiguera, a Barcelona ${ }^{130}$. El Dr. Ernesto Roma va crear la primera associació per a pacients amb DM el 1926, l'Associação Protectora dos Diabeticos de Portugal (APDP), i immediatament després va introduir l'educació diabetològica com a eina vital per permetre les persones amb DM realitzar un autocontrol de la glucosa, autoinjectar-se la insulina i fer una dieta adequada. Així es va introduir el concepte d'educació diabetològica a Europa. A més, durant algunes dècades va mantenir l'única escola sobre DM per a metges i infermeres ${ }^{131}$.

També el Dr. Lawrence, que va fundar la British Diabetic Association el 1934, va remarcar en un dels llibres que va publicar el $1925^{132}$ la necessària col·laboració entre el metge i el pacient com a estratègia fonamental per millorar els resultats.

El Dr. Silvestro Silvestri va ser pioner en la introducció de la teràpia insulínica a Roma, i juntament amb la seva esposa Margherita Lapena va començar a fer educació als pacients amb $D^{133}$. Va fundar l'Associació Italiana de Diabetis el $1952^{134}$.

Al nostre país, concretament a Barcelona, el Dr. Carrasco i Formiguera va ser pioner en l'obtenció d'insulina a Europa, el 1922. Va defensar la importància de l'educació del pacient a l'inici del tractament amb insulina, així com la de la formació dels professionals, manifestant el següent: «Durante el periodo inicial de hospitalización, la duración de la cual suele ser de dos a seis semanas, el enfermo, además de ser tratado con precisión y eficacia, recibe la instrucción necesaria sobre problemas que tanto le interesan, como la alimentación en general, la diabetes en general, el tratamiento dietético de la misma, la insulinoterapia, etc.; aprende a darse inyecciones, si así se estima conveniente, a conocer los peligros que le rodean y la manera de evitarlos, a dar el valor debido a los alimentos, a comprender la orientación de las prescripciones médicas y la necesidad de cumplirlas fielmente, a variar su alimentación dentro de las órdenes del médico, a analizar su orina y dar el valor debido a los resultados de estos y otros análisis, y otras cosas y detalles que tendrán un valor inestimable; en una palabra, es educado para convertirse en un colaborador inteligente y fiel del médico que después habrá de tener la dirección y responsabilidad del tratamiento». I afegeix: «El médico general puede y en algunos casos debe emplear la insulina, pero para ello, es indispensable que tenga o adquiera conocimientos teóricos y prácticos que no tienen nada de extraordinario, pero que la generalidad de los médicos no poseen actualmente $\aleph^{135}$. Tot i el reconeixement innegable del valor de l'educació del pacient que ja donava el Dr. Carrasco i Formiguera, es pot observar en aquestes paraules el caràcter autoritari i prescriptiu de la relació professional-pacient corresponent al model biomèdic d'atenció a la salut, on és el professional qui té el coneixement, i el pacient qui ha de complir fil per randa les ordres mèdiques.

El tractament de la DM, igual que la prevenció de les complicacions, ha estat estretament vinculat amb el desenvolupament científic i tecnològic. Arran del descobriment de la insulina, l'ús dels antibiòtics després de la Segona Guerra Mundial, i dels hipoglucemiants orals el 1942, van permetre un millor control de la malaltia. El 1962, amb el descobriment dels primers aparells per mesurar la glucèmia, el pacient ja podia autocontrolar la seva glucèmia de manera ràpida i senzilla, i adaptar les dosis d'insulina a aquests resultats, la qual cosa li oferia una major autonomia i afegia valor al paper de l'educació. 
Malgrat les idees d'aquells diabetòlegs pioners al voltant de la importància d'educar el pacient i fer-lo partícip del tractament, aquestes no van ser fàcilment acceptades per la medicina oficial, ja que el fet que els pacients participessin activament en el tractament representava una revolució en la tradicional i autoritària relació entre la infermera i el metge i el pacient ${ }^{133}$.

Més tard, el període entre 1970 i 1980, coincidint amb el desenvolupament del model d'atenció biopsicosocial, es va caracteritzar per la consciència de la importància que tenia l'educació del pacient en la terapèutica. Els treballs de L. Miller el 1972, als EUA ${ }^{136}$, van donar la primera evidència científica de l'eficàcia dels programes educatius estructurats per prevenir les complicacions agudes i reduir la despesa sanitària, incorporant l'automonitoratge de la glucèmia capil.lar (AMGC), un dels avenços més rellevants en el tractament de la DM, i introduint-hi la figura de la infermera educadora o especialista en diabetis i educació. Va demostrar que gràcies a l'educació dels pacients es va reduir en un 80 \% els episodis greus d'hipoglucèmia i el nombre de comes hiperglucèmics d'origen diabètic. També va observar una disminució d'aproximadament el $80 \%$ en les consultes urgents per problemes dels peus.

Al cap d'un any, al 1973, es va fundar als EUA l'Associació Americana d'Educadors en Diabetis (American Association of Diabetes Educators, $A A D E)^{137}$, una associació multidisciplinària que acull tots aquells professionals especialitzats en l'educació de les persones amb DM (professionals de la infermeria, dietistes, farmacèutics i altres). Treballa per definir la qualitat de l'educació, augmentar l'accés dels pacients als serveis que ofereixen els educadors i proporcionar als seus membres el suport i les eines per convertir-los en líders en el camp de l'educació en la diabetis i la seva prevenció.

Als anys setanta, a Europa, altres grups de diabetòlegs, com el de Davidson ${ }^{138}$, a Atlanta, el del Dr. Berguer i el Dr. Jörgens ${ }^{139,140,}$ a Düseldorf, i el de Jean Philippe Assal, a Suïssa, van ser també pioners a introduir l'educació diabetològica estructurada com una part del tractament de la DM. Els resultats dels seus estudis van ser similars en termes de reducció de complicacions i costos associats ${ }^{141}$.

El Dr. Assal, diabetòleg, va desenvolupar una tasca pionera a Europa en integrar en el seu servei hospitalari l'educació dels pacients. Estava convençut que l'educació de les persones amb DM i els seus familiars havia de ser una part de l'atenció prestada per l'equip de salut. Va fundar la primera Unitat Docent i de Tractament de la Diabetis de l'Hospital Universitari de Ginebra, al 1975. Els seus treballs sobre el paper del professional de la salut en la relació educativa asseguren un reconeixement científic sobre l'educació del pacient i una difusió internacional d'aquest enfocament. Va demostrar l'eficàcia dels programes educatius ${ }^{122,124,142,143}$ en la prevenció de lesions al peu, en la reducció d'amputacions d'extremitats inferiors i en els dies d'estància hospitalària, demostrant que el cost directe d'una amputació és equivalent al sou d'un any d'un equip format per un endocrinòleg, una infermera educadora en DM, un podòleg i un cirurgià vascular treballant de forma interdisciplinària ${ }^{142,144}$. 
El Dr. Assal va ser el primer president del Diabetes Education Study Group (DESG), fundat el 1979 en el Primer Simposi Europeu d’Educació sobre la Diabetis, celebrat a Ginebra ${ }^{145}$. Aquest grup d'estudi per a l'educació en la DM és multidisciplinari i constitueix un dels grups de treball de l'European Association for the Study of Diabetes (EASD). Els seus objectius inicials, que encara prevalen, són:

- Augmentar l'eficàcia i eficiència en el tractament de la DM.

- Millorar la qualitat del control en una fase no aguda de la DM, en la qual són crucials l'educació del pacient i una relació significativa professional de la salut i el pacient orientada a les necessitats del pacient.

- Fomentar la investigació en els camps de l'educació i el tractament de la DM i desenvolupar mitjans d'avaluació de l'educació del pacient.

El DESG ha realitzat al llarg dels anys diverses activitats d'acord amb els seus objectius com, com146:

- Tallers d'educació per a professionals: en aquests tallers anuals de 5 dies de durada, amb uns 30-60 participants (d'àmbit multidisciplinari), la característica principal és l'estricta execució del principi d'«aprendre fent»; per tant, cada activitat és una ocasió per centrar-se en un aspecte específic de l'ET dels pacients i una oportunitat d'experimentar un mètode d'aprenentatge que pot ser adoptat també pel professional en l'educació del pacient (metaplans, jocs de rol, aprenentatge basat en les experiències i en les discapacitats).

- Teaching letters: des del 1983 i fins al 1998, el DESG en va elaborar vint-i-quatre, les quals estan traduïdes a vint-i-sis idiomes. Les teaching letters, o cartes educatives, són una guia per a l'educació del pacient en relació amb els diferents aspectes del tractament i el suport motivacional i psicològic. S'han utilitzat també per a l'educació de professionals ${ }^{147}$.

- The 5 min education kit, o carpetes educatives de supervivència ${ }^{148}$ : aquests documents, que cobreixen 9 tòpics, es van elaborar com una solució per a aquells professionals que posen com a excusa la manca de temps per no educar els pacients. Amb cinc minuts no es pot educar, però es pot donar la informació justa i adient.

- Patient education basics, o conceptes bàsics per a l'educació del pacient: són documents dirigits principalment a l'educació de les persones amb DM2 i que intenten cobrir dues qüestions essencials: a) Com proporcionar en cinc minuts una informació útil perquè el pacient pugui gestionar millor la $\mathrm{DM}, \mathrm{i} b$ ) Com podem estar segurs que el pacient seguirà els consells un cop torni a casa.

- Basic curriculum in therapeutic patient education ${ }^{120}$ : elaborat l'any 2000, defineix el currículum formatiu que han de tenir els professionals que es dediquen a l'ET. 
La pertinència de l'educació del pacient va ser proclamada per l'OMS en la Declaració de Saint Vincent el $1989^{149}$. L'OMS va acceptar que la DM era ja un greu problema de salut, i a Europa, representants de societats i col-legis professionals, associacions de persones amb DM i institucions governamentals es van reunir amb la finalitat de discutir sobre l'organització de l'assistència diabetològica a tots els països europeus. Al final de la reunió, una comissió formada per l'OMS-IDF va elaborar unes recomanacions per als ministeris de Sanitat dels respectius governs europeus. Se'ls hi demanava la responsabilitat que per a l'any 1995 es fessin tots els esforços per disminuir un $50 \%$ el nombre d'amputacions, un $30 \%$ els casos de ceguesa i un $30 \%$ els casos d'insuficiència renal, mitjançant:

- L’aplicació d'estratègies de prevenció i tractament de les complicacions cròniques.

- L’organització de programes de formació i educació per a pacients i professionals.

- La promoció i el suport a la recerca en DM.

- L'establiment de mecanismes de control de qualitat del sistema sanitari.

Tots aquests programes necessitaven inversions de gran magnitud per part dels prestadors de serveis de salut, en el terreny de l'educació al pacient diabètic.

L'any 1994 es va establir la Consultative Section on Diabetes Education (DECS) ${ }^{150}$, de la IDF, que identifica i aborda qüestions relatives a l'educació i el tractament de la DM a escala internacional. Es compromet a millorar la qualitat de vida de les persones amb DM a través de l'ajut als professionals sanitaris, les organitzacions professionals i els membres de les associacions, per oferir educació i atenció a la DM d’alta qualitat.

Les principals àrees de treball del DECS inclouen:

- Desenvolupar el lideratge dels professionals sanitaris.

- Desenvolupar eines i recursos per a l'educació i la formació dels professionals de la salut.

- Desenvolupar aliances estratègiques.

- Fomentar la comunicació i l'intercanvi de coneixements entre els professionals de la salut involucrats en la cura de la DM i en la investigació.

- Reconèixer els centres d'educació en DM d'alta qualitat com a exemples de la formació dels professionals de la salut.

- Oferir els programes de capacitació interdisciplinaris de gran qualitat.

- Proporcionar assessorament especialitzat a les activitats d'educació sobre DM i un Certificat de la Federació Internacional de Diabetis. 
Hi ha dos estudis que han marcat un clar referent en el tractament de la DM: un és el Diabetes Control and Complications Trial (DCCT) ${ }^{28}$, del 1993, que es va realitzar en pacients amb DM1, $\mathrm{i}$ I'altre és el UK Prospective Diabetes Study (UKPDS) ${ }^{31}$, del 1998, fet en pacients amb DM2. Ambdós estudis van demostrar una relació entre el control metabòlic i l'aparició de complicacions cròniques. En el DCCT la reducció del risc de presentar una complicació microvascular va estar entre un $35 \%$ i un $76 \%$. L'UKPDS va demostrar la necessitat de prevenir i/o tractar els factors de risc cardiovascular (FRCV). Aquests dos estudis van evidenciar el paper dels professionals d'infermeria com a peces clau en l'educació i el suport als pacients, per poder seguir les recomanacions del tractament intensificat.

El 1995 Clement ${ }^{151}$ va publicar una revisió de 141 programes educatius estructurats i va concloure que l'educació és més eficaç si:

- Per al canvi de comportament s'utilitzen estratègies dirigides a augmentar les competències dels pacients, en lloc d'augmentar-ne només els coneixements. Això significa valorar la situació individual de cada persona i les possibles barreres per a l'autocura (creences, recursos, situació sociofamiliar i econòmica).

- Està integrada dins del tractament.

- Els professionals treballen conjuntament amb el pacient algoritmes de modificació de tractament de forma personalitzada i li reforcen les conductes apreses.

Aquesta revisió també va demostrar que l'automonitoratge de la glucèmia capil·lar (AMGC) és essencial per obtenir un millor control de la malaltia, especialment en pacients tractats amb insulina, i va tornar a demostrar que l'educació estructurada s'associa amb una reducció del nombre d'hospitalitzacions per causa de la DM, amb la prevenció de complicacions agudes i cròniques, sobretot lesions i amputacions a extremitats inferiors, i, per tant, amb una reducció de la despesa sanitària relacionada amb la DM. Estudis més recents han mostrat els mateixos resultats $^{152}$.

Altres estudis han demostrat la importància de l'educació de les persones amb DM i les seves famílies a l'hora de superar les barreres que dificulten el control de la malaltia i de millorar el coneixement i els comportaments d'autocura, fet que repercuteix en una millora dels resultats clínics, en un afrontament més saludable de la malaltia, en una disminució dels costos sanitaris i en un augment de la qualitat de vida ${ }^{153,154}$

L'Associació Americana d'Educadors en Diabetis (AADE) va establir set comportaments d'autocura essencials en les persones amb DM que prediuen bons resultats ${ }^{155}$, ja que s'han correlacionat positivament amb un bon control de la glucèmia, una reducció de les complicacions i una millora en la qualitat de vida ${ }^{156,157}$ 
Aquests són:

1. Alimentació saludable

2. Activitat física

3. Control de la glucèmia

4. Adherència al tractament farmacològic

5. Habilitats en la resolució de problemes

6. Habilitats d'afrontament saludable

7. Comportaments de reducció de riscos

Actualment, ningú no dubta de l'efectivitat de l'educació, però sí que es qüestiona que el nivell adquirit es pugui mantenir en el temps si no s'utilitzen intervencions adaptades a les diferències culturals, l'edat, la situació individual i les estratègies dirigides a mantenir el canvi de comportament a llarg termini, ja que l'efecte de l'educació sobre el control metabòlic tendeix a desaparèixer de forma gradual amb el temps, d'acord amb els principis de qualsevol procés educatiu, perquè els canvis de comportament no es produeixen ràpidament i són diferents en cada persona ${ }^{158}$. Calen més estudis sobre l'efectivitat de programes d'ET a llarg termini, atès que la majoria d'estudis no superen el dos anys de seguiment ${ }^{159}$.

\subsubsection{Estratègies i mètodes educatius}

L'ET és un procés educatiu que, en definitiva, ha seguit l'evolució de l'educació en general. Tradicionalment l'educació del pacient era prescriptiva, el professional era qui sabia i establia els objectius, i el pacient havia de complir les recomanacions. Aquest model tradicional, considerat com un sistema de transmetre informació de forma unidireccional, ha demostrat tenir poc efecte en l'autonomia dels pacients ${ }^{160}$.

Les ciències de l'educació, i especialment les referents als mecanismes d'aprenentatge, ens han ajudat a conèixer millor els processos que segueix l'alumne (pacient) a l'hora d'aprendre. Quan un professional sanitari ensenya per mitjà de xerrades o conferències pensa que el pacient està absolutament disposat a rebre el missatge, i en general no és així. La transmissió del coneixement està lligada a una certa identitat mental i a unes creences que poden ser molt diferents entre el professional i el pacient ${ }^{161}$. En el cas de la DM, la gran quantitat d'informació, tècniques i habilitats pràctiques que ha d'assolir el pacient és un repte important per als professionals, que hauran de treballar juntament amb els pacients a través de diferents estratègies educatives. La qüestió no està en el contingut, sinó en el mètode, és a dir, no en el que s’ha d'aprendre sinó en com s'ha d'aprendre. 
El Diabetes Education Study Group (DESG), de l'European Association for the Study of Diabetes (EASD), recomana una sèrie d'estratègies educatives que han demostrat ser eficaces de cara a l'educació de pacients i que es poden utilitzar de forma individual i grupal162.

- Conèixer el punt de partida del pacient, afavorint l'escola activa i la reformulació.

- Utilitzar un llenguatge senzill i comprensible.

- Fer ús de les metàfores.

- Posar el pacient en situació activa.

- Reformular els errors, no penalitzar-los, i utilitzar-los com a instruments d'aprenentatge.

Actualment, les tendències pedagògiques van dirigides al «procés d'aprenentatge» i a «l'atenció centrada en el pacient»: això significa que els educadors han d'oferir les condicions necessàries relacionades amb els coneixements, les habilitats, les actituds i el suport per afavorir la reflexió activa, el diàleg i el pacte, que són les bases per ajudar el pacient a canviar el comportament de salut de manera voluntària i perquè pugui gestionar millor la seva malaltia. Un dels models d'atenció centrada en el pacient que ha demostrat bons resultats és el de l'empowerment ${ }^{163,164}$, basat en la decisió compartida. Es treballa amb el pacient i no per al pacient. Se'l capacita perquè adquireixi el control i la responsabilitat del maneig diari de la seva DM, tenint en compte els seus objectius, prioritats i estil de vida, és a dir, ajuda que el pacient descobreixi i desenvolupi la seva capacitat innata per ser responsable del seu propi tractament. El paper dels pacients és estar tan ben informats com sigui possible, per ser actius collaboradors en l'autocura; d'altra banda, els professionals de la salut tenen el paper d'ajudar els pacients a prendre decisions informades per assolir els objectius i per superar les barreres a través de l'educació, les recomanacions apropiades de tractament i autocura, l'assessorament especialitzat i el suport en el seguiment de la malaltia ${ }^{165}$.

El procés d'aprenentatge no s'acaba mai i és un treball de col·laboració entre el pacient, la família i l'equip de salut. Les principals guies científiques recomanen que l'ET s'ha de plantejar en el marc de programes estructurats. En els programes s'hi defineixen els objectius d'aprenentatge, la metodologia i les activitats que cal realitzar, així com el seguiment i l'avaluació, tant de les intervencions com del mateix programa. Aquests programes s'hauran d'adaptar a les necessitats educatives dels pacients o de la família.

Aquesta educació estructurada ha d'estar a disposició de totes les persones amb DM en el moment del diagnòstic i en el seguiment de la malaltia, ja que les necessitats dels pacients poden variar al llarg del temps. Cal destacar que els principals objectius de l'ET són aconseguir una bona adherència al tractament i millorar la qualitat de vida. Per tant, l'avaluació de l'adherència terapèutica i la qualitat de vida s'han d'incloure en els programes $d^{\prime} E T^{166,36}$. 
La planificació dels programes educatius consisteix a organitzar en el temps el procés d'aprenentatge que ha de seguir el pacient perquè l'ajudin a aconseguir els objectius pactats. En aquest procés, les intervencions educatives es poden plantejar de forma individualitzada, com una part integrant de la relació interpersonal entre el professional de la salut i la persona amb DM, o en grup ${ }^{167}$.

No hi ha consens sobre quina d'aquestes intervencions és millor en l'ET: hi ha estudis que demostrem que ambdues són igual d'efectives en termes de millora del control glucèmic $i$ lliurament dels components clau de l'educació, però l'educació grupal pot permetre l'ús de mètodes més eficients i cost-efectius ${ }^{168}$. Altres estudis han demostrat que els programes d'ET estructurada impartida de forma grupal milloren els resultats clínics (reducció d'HbA1c, IMC, TA), educatius i de percepció de qualitat de vida, en comparació amb els impartits de forma

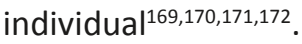

Seguidament, es mostren les característiques en relació amb els avantatges, desavantatges i indicacions de les intervencions individuals i grupals: ${ }^{173}$

\section{- Característiques de l'educació individual}

L'educació individual es basa en una comunicació interpersonal, en el fet de preguntar, escoltar i interpretar per tal d'obtenir una avaluació de les necessitats del pacient.

\section{Avantatges:}

1. El diàleg educatiu individualitzat permet una millor adequació dels objectius a les necessitats, aptituds, coneixements i interessos que té el pacient.

2. Ofereix la possibilitat que el pacient expressi sentiments i emocions, cosa que probablement no faria en una sessió grupal. És aquí on l'educador ha de tenir l'habilitat de saber escoltar de forma activa per avaluar les necessitats expressades i prioritzar els objectius de manera conjunta.

3. No requereix d'un espai especial ni de material sofisticat.

\section{Desavantatges:}

1. Requereix més temps de dedicació per part del professional.

2. Els programes educatius realitzats únicament de forma individual són poc cost-efectius. 


\section{Indicacions:}

1. En el moment del diagnòstic.

2. En l'avaluació inicial i final del programa educatiu.

3. En el seguiment terapèutic.

\section{- Característiques de l’educació grupal}

Un grup no hauria de superar les 15 persones (pacients i familiars). Si en una dinàmica de grup es vol treballar exercicis pràctics, el nombre d'integrants no hauria de superar les 5 persones.

Abans d'iniciar les sessions grupals, l'educador ha de procurar seleccionar els pacients per intentar que sigui tan homogeni com sigui possible. Els grups heterogenis són més difícils de conduir.

Les sessions grupals s'han de preparar prèviament quant a continguts i metodologia.

\section{Avantatges:}

1. Afavoreix l'intercanvi d'experiències i ajuda a compartir dubtes i coneixements amb altres persones que pateixen el mateix problema de salut. El treball en grup facilita la motivació, la integració i l'acceptació de la malaltia i promou el canvi de comportament, tot facilitant el procés educatiu.

2. És cost-efectiva (en un grup de 10 persones, cada hora del professional es transforma en 10 hores).

\section{Desavantatges:}

1. Requereix de professionals capacitats i entrenats en tècniques de comunicació $i$ dinàmiques de grup per poder vehicular les reaccions de la comunicació entre els pacients i els familiars i per gestionar els possibles conflictes, com la no participació d’alguns membres o la monopolització de la discussió d’altres.

2. Cal un espai adequat que permeti la participació de tots els assistents. 


\section{Indicacions:}

1. Situacions en les quals es necessita el suport del grup per al canvi de comportament.

2. Necessitat de tractar aspectes que requereixin una participació activa tant del pacient com de la família.

3. Quan la persona ha assimilat els objectius de supervivència i l'impacte del diagnòstic.

\section{- Educació basada en les noves tecnologies:}

Amb l'aparició d'Internet, ja fa més de quinze anys, els pacients i familiars tenen un altre via d'accés a la informació sanitària i poden obtenir dades amb facilitat sobre les malalties que pateixen. Els nous dispositius tecnològics, com aplicacions de mòbils o tauletes $\mathrm{i}$ xarxes socials, ofereixen altres possibilitats en el camp de l'ET i noves vies de relació entre els professionals i els pacients. Els programes educatius en línia són de bona qualitat si ofereixen contingut pertinent, proporcionen elements atractius i interactius i proporcionen un aprenentatge adaptat i personalitzat ${ }^{174}$. En relació amb l'eficàcia d'aquests programes sobre l'autogestió de la malaltia, hi ha poca evidència i la que hi ha és contradictòria ${ }^{175,176}$, però cada vegada hi ha més pacients atrets per aquestes vies educatives i més professionals implicats en el seu ús, fet que justifica poder-los incloure entre els mètodes educatius.

Els resultats d'una revisió sistemàtica recent sobre l'impacte de programes educatius adreçats a persones amb $\mathrm{DM}^{153}$ poden servir de resum d'aquest apartat. L'objectiu d'aquesta revisió era avaluar l'impacte que tenen els programes educatius i els mètodes de suport sobre el control metabòlic, i analitzar les característiques d'aquests programes en relació amb els professionals implicats, la seva duració i les estratègies educatives utilitzades. Es van incloure estudis prospectius aleatoritzats en els quals es valorava l'efecte sobre el control metabòlic, mesurat en $\mathrm{HbA} 1 \mathrm{c}$, dels programes educatius amb estratègies d'afrontament, capacitació i suport als pacients, en contrast amb el seguiment habitual. Els programes educatius es van classificar en: $a$ ) educació individual; $b$ ) educació grupal; c) combinació d'educació individual i grupal, i d) mètodes telemàtics.

L'estudi va demostrar que les intervencions que combinaven educació grupal amb individual disminuïen I'HbA1c $>0,88 \%$. El 70,3\% dels programes amb una durada superior a les 10 hores tenien millores significatives de l'HbA1c i les conclusions a què van arribar van ser que: $a$ ) els programes d'educació i suport a l'autogestió del tractament ajuden a disminuir els nivells d'HbA1c, i $b$ ) totes les intervencions educatives són millors que el seguiment habitual, però els programes més efectius són els que combinen intervencions educatives individuals i grupals, impartits de forma interdisciplinària i que tenen una durada superior a les 10 hores. 


\subsubsection{Posicionament de les societats científiques sobre l'educació terapèu- tica i els estàndards de qualitat}

Per tal de millorar l'eficàcia i l'eficiència de l'ET, tal com recomanen diferents societats científiques, és important treballar amb programes educatius estructurats, de màxima qualitat, utilitzant diferents mètodes educatius i impartits per professionals experts.

- La Federació Internacional de Diabetes (IDF) declara que «l'educació diabètica és una especialitat que exigeix coneixements i competències a nivell avançat. D’aquesta manera, una educació diabètica impartida per professionals sanitaris ben preparats ha de formar part integral de l'atenció clínica, clau per a una bona autogestió del tractament».

Els Estàndards Internacionals d'Educació Diabètica de la IDF, basats en l'evidència científica, diuen ${ }^{177}$ :

1. L'educació és eficaç a l'hora de millorar els resultats clínics i la qualitat de vida, almenys a curt termini.

2. L'educació diabètica ha evolucionat a partir de presentacions fonamentalment didàctiques cap a models més teòrics basats en la capacitació.

3. No hi ha un programa ni un enfocament educatiu únic que sigui millor que la resta. No obstant, els programes que incorporen estratègies conductuals i psicosocials han demostrat millorar els resultats. Estudis addicionals mostren que els programes adaptats segons l'edat o la cultura milloren els resultats i que l'educació en grup és, com a mínim, igual d’eficaç que l'educació individual.

4. El suport continu és fonamental per tal de mantenir el progrés en l'educació dels pacients. Les persones amb DM experimenten una considerable angoixa psicològica en el moment del diagnòstic i al llarg de la seva vida, i aquests problemes psicosocials afecten els seus esforços per autocontrolar-se.

5. Algunes estratègies, com l'establiment autodirigit d'objectius i la resolució de problemes, són eficaços a l'hora de promoure el canvi conductual.

6. Per oferir una educació de qualitat és imprescindible la formació dels professionals. L'ET és una especialitat i exigeix coneixements i competències en un nivell avançat, si es vol impartir amb eficàcia. 
- Al Regne Unit, el National Institute for Clinical Excelence (NICE) ${ }^{178}$ defineix un programa d'educació estructurat com: «Un programa planificat, progressiu, coherent amb els objectius, flexible en el contingut i que respongui a les necessitats clíniques i psicològiques d'una persona i que s'adapti al seu nivell acadèmic i cultural». Els cinc criteris fonamentals que ha de complir un programa estructurat d'alta qualitat, establerts pel Departament de Salut i el Grup de Treball d’Educació al Pacient amb Diabetis del Regne Unit, són:

1. Qualsevol programa ha d'estar basat en l'evidència i adaptar-se a les necessitats de l'individu. Ha de tenir objectius específics d'aprenentatge i ha d'afavorir el desenvolupament d'actituds, creences, coneixements i habilitats per tal de millorar l'autogestió de la malaltia, tant del pacient com dels seus familiars o cuidadors.

2. Ha de tenir una planificació estructurada, basada en la teoria i l'evidència, amb recursos efectius humans i materials, i ha de constar per escrit.

3. Ha d'estar impartit per educadors capacitats, competents i amb una comprensió de la teoria educativa adequada a l'edat i les necessitats de les persones.

4. Ha de tenir garantia de qualitat, i ser revisat per personal capacitat, competent i independent, pel tal de garantir la coherència del programa.

5. Els resultats del programa han de ser auditats periòdicament.

- El sistema de salut francès, l'anomenat Haute Autorité de Santé (HAS) ${ }^{179}$, té exigències de qualitat molt elevades per a tot el que es refereix a tenir cura de la salut. Acredita i certifica els professionals de determinades disciplines per avaluar i millorar la qualitat de l'atenció i la seguretat del pacient als centres de salut i en la pràctica en general. El HAS defineix un programa estructurat com un conjunt coordinat d'activitats educatives portades a terme per professionals de la salut. Va dirigit als pacients i a les seves famílies i contribueix que s'assoleixin els objectius (adquisició i manteniment de coneixements, habilitats d'autocura o afrontament de la malaltia). Es realitza en un context determinat i també en un període determinat. Perquè aquests programes siguin de qualitat, han de:

1. Estar centrats en el pacient.

2. Estar basats en l'evidència científica.

3. Formar part integral de l'atenció i el tractament, i estar adaptats a l'evolució de la malaltia.

4. Ser duts terme per professionals de la salut capacitats pel que fa a l'ET i a les tècniques pedagògiques. 
5. Basar-se en l'avaluació de les necessitats i de l'entorn del pacient, i construir-se en base a les prioritats d'aprenentatge percebudes pels professionals de la salut i els pacients.

6. Adaptar-se al perfil educatiu i cultural del pacient, i respectar les seves preferències, estil i ritme d'aprenentatge.

7. Estar definits en termes de continguts i activitats, s'han d'organitzar en el temps i s'han d'emprar diversos mètodes i tècniques educatives.

8. Ser multiprofessionals, interdisciplinaris i multisectorials.

9. D'incloure una avaluació individual i del desenvolupament del programa.

- L'American Diabetes Association (ADA) ${ }^{61}$ es posiciona sobre l'educació (diabetes self-management education) amb els arguments següents:

1. L'educació és un element clau en el tractament de la malaltia. Ha d'anar dirigida a tots el pacients amb DM i prediabetis, així com als seus familiars.

2. Permet als pacients prendre decisions informades que repercutiran en un millor control de la malaltia.

3. L'educació ha d'estar centrada en el pacient i/o la seva família, i s'ha de basar en les seves preferències, necessitats, cultura i valors.

4. Ajuda a prevenir les complicacions tant agudes com cròniques d'una manera cost-efectiva.

- Els National Standards for Diabetes Self-management Education and Support ${ }^{180}$, pactats per les diferents societats científiques relacionades amb la DM i les associacions de pacients, proposen deu estàndards de qualitat dels programes de DSME/S, que es revisen cada cinc anys. En l'última revisió van dirigits també a millorar les estratègies en l'educació de les persones amb prediabetis :

1. El programa educatiu ha d'estar ben definit respecte de l'estructura organitzativa, la finalitat i els objectius.

2. Per tal de promoure la qualitat del programa, s'ha de formar un grup consultor constituït per professionals experts, pacients amb DM i altres persones interessades.

3. S'han de determinar les necessitats educatives de la població a qui va dirigit el programa. 
4. Un coordinador amb coneixements i experiència en ET tindrà la responsabilitat de supervisar la planificació, la implementació i l’avaluació dels programes de DSME/S.

5. El responsable de la DSME/S ha de ser un educador amb acreditació certificada. Podrà ser una infermera, un metge, un dietista o un farmacèutic. Altres professionals de la salut no acreditats però amb formació adequada en DM poden contribuir a l'educació del pacient, però amb supervisió i suport.

6. El programa ha de constar per escrit. Ha d'estar basat en l'evidència i en les guies de pràctica clínica, amb criteris per a l'avaluació de resultats. S'ha d'adaptar a les necessitats individuals, $\mathrm{i}$ ha de ser interactiu i centrat en el pacient.

7. L'avaluació del programa la realitzaran tant els educadors com els participants, però de manera individualitzada, tenint en compte aspectes com l'edat, les comorbilitats, les creences, les actituds, els coneixements, les habilitats, el nivell cultural i el suport familiar, per tal de trobar les millors estratègies educatives que ajudin al canvi de comportament.

8. Cal fer un seguiment personalitzat, pactat entre l'educador i el pacient. La majoria de pacients necessiten un seguiment per al reforç educatiu, psicosocial o clínic.

9. L'avaluació dels resultats s'ha de fer en intervals apropiats. Aquests intervals dependran dels objectius pactats i de la capacitat d'aprenentatge del pacient. S'han d'utilitzar instruments de mesura adequats a cada objectiu. L'adherència a les conductes d’autogestió del tractament són l'aspecte més important en l'avaluació dels resultats.

10. L'avaluació del procés educatiu permetrà identificar les àrees de millora del programa i poder fer-hi els canvis necessaris.

- L'European Association for the Study of Diabetes (EASD), a través del grup Diabetes Education Study Group (DESG), centrat en l'estudi per a l'educació en la diabetis, emfatitza la necessitat que els professionals que imparteixen l'educació als pacients adquireixin una sèrie de competències i habilitats que no estan incloses en el currículum de formació mèdica tradicional. El DESG va crear el currículum bàsic en educació terapèutica en diabetis per a professionals de la salut ${ }^{120}$,on es defineixen les competències bàsiques que els professionals han d'assolir en diferents àrees com la pedagogia, psicologia, sociologia i ciències de la comunicació.

- La Sociedad Española de Diabetes (SED) es posiciona a favor d'un currículum professional específic dels professionals de la infermeria en l'atenció de les persones amb DM, amb una acreditació obtinguda a través d'una formació acadèmica universitària. Aquesta formació ha d'incloure dominis i competències relacionades amb la biomedicina, cures del pacient i la família, educació terapèutica, gestió i investigació ${ }^{181}$. El posicionament de la SED es basa en les recomanacions de les principals societats científiques internacionals. 


\subsubsection{Evolució del paper de la infermera en l'educació de les persones amb diabetis}

És als EUA on es troben les primeres referències del paper de la infermera en la cura de les persones amb DM i de les seves famílies. La informació que es disposa del paper de la infermera en l'educació de les persones amb DM data d'abans del descobriment de la insulina. La situació de les persones amb DM i les famílies era desesperada. Les infermeres atenien els pacients a l'entorn de la llar a fi d'alleugerir el sofriment, tant del pacient com de les famílies, donant suport a les teràpies nutricionals que en aquell moment es practicaven, com la «teràpia del dejuni», per disminuir l'acidosi i la glucosúria ${ }^{182}$. Entre el 1914 i el 1916 la tasca de les infermeres anava orientada a recollir mostres d'orina, fer el control de pes, preparar i administrar dietes o pautes d'alimentació, ajudar a reduir l'estrès o monitorar els estats de coma ${ }^{183}$.

El Dr. E. Joslin va publicar al 1914 unes observacions en què ressaltava la necessitat de formar infermeres perquè emprenguessin tasques d'educació i control de persones amb DM, i va afirmar que especialitzar-se en DM oferia una nova carrera per a les infermeres. Va fer de l'educació diabetològica una de les primeres àrees de la infermera especialista. Va afirmar que "una infermera ben entrenada té més valor que un metge». A més, va subratllar la importància de l'educació de la infermera en DM i la seva responsabilitat a l'hora d'aprendre i entendre les bases del tractament ${ }^{184}$.

El paper de la infermera, però, va patir un canvi important desprès de la Primera Guerra Mundial, quan les infermeres van començar a aprofundir en diferents àrees d'interès i a formar-se dins d'aquestes àrees ${ }^{185}$.

Quan el paper de la infermera en el tractament de la DM pren més rellevància és a partir del descobriment de la insulina, l'any 1921. La necessitat que les infermeres desenvolupessin habilitats educatives per ensenyar les persones a punxar-se la insulina o a comptar els carbohidrats de l'alimentació va reforçar el seu paper en el camp de l'atenció a la DM. La seva formació en habilitats educatives i d'assessorament, així com l'adquisició de competències en l'atenció clínica, es va fer més patent ${ }^{183}$.

Cap a la segona meitat dels anys trenta, quan la insulina ja es trobava fàcilment en el mercat, el Dr. Joslin va crear la figura de la wandering nurse o infermera itinerant ${ }^{186}$. Aquesta infermera tenia la funció d'ensenyar els pacients amb DM1 i les seves famílies l'administració de la insulina i com prevenir les complicacions agudes (hipoglucèmia i hiperglucèmia); realitzava l'educació en el domicili del pacient, a l'hospital, a les escoles i també en els campaments per a nens amb DM, que ell va crear per afavorir la integració social de la malaltia. Podem dir, doncs, que va crear la figura de la infermera educadora de DM.

El 1936 una infermera educadora va publicar el primer article sobre el model d'educació diabetològica i el paper de la infermera educadora, en el qual ja manifestava la importància d'individualitzar l'educació, d'escollir els objectius educatius i del valor que té el treball en equip. També especificava el pla d'educació per a altres infermeres i les estratègies educatives que calia seguir ${ }^{182}$. 
Als anys cinquanta van aparèixer els medicaments hipoglucemiants orals com a conseqüència de l'increment de la DM2, un problema sanitari creixent en tot el món i amb unes exigències de prevenció, tractament, atenció i control en el qual els professionals d'infermeria hi van adquirir un paper rellevant. En aquell moment, quan s'havia definit la figura de la infermera especialista com aquella que proporcionava una atenció d'alt nivell i era capaç de funcionar de manera autònoma ${ }^{187}$, va ser l'educació en DM una de les primeres especialitats de la infermeria i va servir com a model per a altres especialitats. L'aparició a finals dels anys setanta de les tires reactives per al control domiciliari de la glucèmia, l'evolució de les tecnologies i l'evidència de la investigació van contribuir a l'expansió de la figura de l'educador en $\mathrm{DM}^{188}$.

La publicació dels resultats de l'estudi DCCT ${ }^{28}$ al 1993, i més tard les del UKPDS ${ }^{31}$ al 1998, van canviar l'enfocament de l'atenció a la DM: ja no es buscava únicament la reducció dels valors de glucèmia i de les xifres de TA, sinó també la prevenció activa de les complicacions i la intensificació del tractament amb uns objectius metabòlics estrictes. Les infermeres no només proporcionaven educació als pacients, sinó que s'involucraven en aspectes més clínics, com ara ajustar les dosis d'insulina, les calories o els carbohidrats del pla d'alimentació, i orientar sobre l'exercici. Això va contribuir a intentar definir el rol de la infermera especialista en DM i a establir el valor de l'equip multidisciplinari centrat en la persona.

Actualment, la figura de la infermera és un dels components clau en el tractament de la DM, i el seu paper és determinant tant per a la prevenció, l'educació i el suport al pacient, a les famílies i a la comunitat com per al desenvolupament de sistemes d'atenció més eficaços ${ }^{189}$. Per aquest motiu, en diversos països aquest col-lectiu ha buscat un reconeixement oficial de la tasca que fan, atenent a la formació específica que s'hi requereix, la qual no es proporciona dins la carrera d'Infermeria.

\subsubsection{Formació i acreditació en diabetis dels professionals d'infermeria}

Tot i que l'educació és responsabilitat de qualsevol membre de l'equip terapèutic que tracta la persona amb DM, en la majoria de països són els professionals d'infermeria els que lideren tot el procés educatiu' 190 .

Les diferents organitzacions i associacions internacionals de la DM afirmen que el treball en equip i la formació dels professionals és clau si es vol oferir una educació de qualitat i obtenir millors resultats terapèutics. Aquesta formació no s'ha de basar solament en aspectes biomèdics, sinó també en habilitats comunicatives, ús de tècniques pedagògiques, planificació de programes educatius, treball en grup de pacients i familiars, organització per al seguiment de la malaltia i avaluació de resultats. Tant a escala nacional com internacional hi ha una gran diferència entre els currículums formatius dels professionals, així com pel que fa la seva acreditación ${ }^{191}$ : 


\section{- EUA i Canadà}

El 1986, amb el suport de l'American Association of Diabetes Educators (AADE), es va crear el Certified Diabetes Educator (CDE), dirigit a tots aquells professionals de salut que formen part de l'equip terapèutic de la DM. Aquesta acreditació oferia el màxim reconeixement com a expert en «educació per a la diabetis» i era imprescindible per poder acreditar els programes d'educatius.

Als anys noranta, als EUA, com a conseqüència dels nous plans d'estudi van aparèixer les infermeres clíniques especialistes. Eren llicenciades i disposaven d'un màster o doctorat d'infermeria clínica. A més, en la majoria d'estats es requeria no només una qualificació educativa, sinó també una acreditació d'especialitat en una àrea concreta. Això va suposar un problema per a les infermeres especialitzades en DM que disposaven del CDE, ja que aquest va deixar de ser reconegut per les asseguradores mèdiques per al reembossament del seus serveis. Per tant, es va proposar la creació d'una acreditació de pràctica avançada per a infermeria específica per a la $\mathrm{DM}^{190}$.

L'any 2000, amb la col·laboració de diferents societats científiques, es va crear el Board Certified-Advanced Diabetes Manager (BC-ADM) ${ }^{192}$, que és una acreditació de pràctica avançada adreçada específicament a infermeres, dietistes i farmacèutics. S'ha de renovar cada cinc anys mitjançant un examen i cal acreditar un mínim de 1000 hores de pràctica clínica avançada en el maneig de la DM. L’objectiu és garantir que els professionals mantenen un nivell de formació continuada suficient per garantir una atenció de qualitat ${ }^{193}$.

Al Canadà també hi ha un certificat oficial com a educador en DM, el Canadian Diabetes Education Certification Board (CDECB) ${ }^{194}$. És un programa de formació de postgrau universitari que està dividit en tres nivells de formació (bàsic, intermedi i avançat). S'ha de renovar cada cinc anys i s'han d'acreditar 800 hores d'experiència en educació en DM.

\section{- Europa}

A diferents països europeus hi ha programes nacionals acreditats que són necessaris per optar a una plaça d'educador en DM. Però l'única acreditació homologada a Europa és la que promou la Foundation of European Nurses in Diabetes (FEND)195 a través de I'European Nurses Diabetes Collaborative University Programme (ENDCUP). És un programa de postgrau que actualment s'imparteix al King's College London. Acredita la figura de la infermera especialista en DM a través d'una formació reglada en àrees clíniques, educatives i d'investigació. 


\section{- Espanya}

No s'ha aconseguit la titulació d'infermera especialista en DM, tot i que ja als anys vuitanta i noranta la Federación Española de Asociaciones de Educadores en Diabetes (FEAED) i l'Associació Catalana d'Educadors en Diabetis (ACED) la demanaven. Tampoc estan reconeguts els professionals d'infermeria que disposen del títol europeu obtingut per mitjà del programa ENDCUP.

L'«Estrategia para la Diabetes» ${ }^{196}$, del Ministeri de Sanitat, elaborada el 2006 i actualitzada per última vegada el 2012, valora com a imprescindible la formació dels professionals, però no en defineix cap programa curricular.

En algunes universitats, com la de Barcelona, fa anys que s'imparteix un màster de títol propi sobre l'atenció a les persones amb DM, però cap d'aquests programes formatius tenen valor curricular per treballar en l'atenció a les persones amb $\mathrm{DM}^{197}$. A més, als professionals d'infermeria no se'ls hi exigeix cap formació, a part de la carrera, per treballar en l'atenció i l'educació de les persones amb DM: la formació es voluntària i això pot crear una gran desigualtat entre professionals que treballen en un mateix àmbit.

Per fer front a aquesta realitat, el posicionament de la SED sobre quin ha de ser el perfil curricular d'un professional d'infermeria expert en l'atenció de les persones amb DM i dels seus familiars o cuidadors s'adreça a totes les direccions d'infermeria dels hospitals del territori espanyol i als caps de servei de les unitats d’Endocrinologia, Diabetis i Nutrició. Es recomana que el professional d'infermeria expert en DM tingui l'acreditació d'haver-se format en els següents dominis i competències relacionades amb la formació biomèdica, de l'atenció al pacient i la família, d’ET, de gestió i d'investigación ${ }^{181}$ :

1. Domini I: Fisiopatologia, Epidemiologia i Guies Clíniques de la Diabetis. Competència perquè el professional de la infermeria expert demostri els coneixements de fisiopatologia, epidemiologia i guies clíniques rellevants per oferir un tractament de la DM basat en l'evidència, en els diferents nivells d'atenció.

2. Domini II: Tractament culturalment competent durant tota la vida. Donar suport a les persones amb DM i als familiars i cuidadors, d'una manera culturalment competent al llarg de tota la vida.

3. Domini III: Habilitats d'ensenyança-aprenentatge. Competència per aplicar els principis d'ensenyança-aprenentatge i/o canvi de comportament per treballar les habilitats d'autocura amb les persones diabètiques i els seus familiars o cuidadors.

4. Domini IV: Educació per a l'autogestió del tractament. Competència per treballar de forma interdisciplinària i adaptar i pactar les intervencions educatives per a l'autogestió del tractament i les necessitats individuals de cada pacient. 
5. Domini v: Planificació, gestió i investigació. Competència per planificar, gestionar i avaluar els programes educatius estructurats per a l'autogestió de la DM.

Cada domini i competència ha de considerar els objectius d'aprenentatge específics, els coneixements, les habilitats i les estratègies que s'hauran d'actualitzar en funció dels avenços en el tractament de la DM.

\subsubsection{Rol i competències de la infermera en diabetis. Dificultats en la seva definició}

Quan parlem d'infermera en diabetis ens referim a aquella infermera que en la seva pràctica habitual inclou l'educació i el tractament de les persones amb DM, els seus familiars i la comunitat. D'acord amb aquesta definició, són infermeres en diabetis les que treballen tant en l'àmbit de l'AT com les que treballen el de l'AE; la diferència la podríem trobar en el seu rol i en les competències assignades a aquest rol dins de cada àmbit d'atenció.

Tal com s'ha comentat anteriorment, el rol de la infermera especialista en DM ja ve promogut i liderat per un dels equips més rellevants en diabetologia, com va ser el del Dr. E. Joslin, just després del descobriment de la insulina. Però al llarg dels anys la pràctica especialitzada de la infermeria s'ha vist en constant evolució a causa dels nous avenços en la teràpia i la tecnologia.

En alguns països europeus i als EUA han treballat en el desenvolupament d'un marc de diferents nivells de competències per a la infermera en DM que respongui a una formació estructurada i específica basada en coneixements i habilitats necessaris per ser aplicats en àrees tant generals com d'ocupació ${ }^{198}$. D'acord amb la literatura, les competències d'una infermera especialista en DM venen determinades per les d’una infermera clínica especialista ${ }^{199}$.

\subsubsection{La infermera clínica especialista}

L'increment de la complexitat en l'atenció al pacient hospitalitzat va afavorir la necessitat de professionals d'infermeria capaços de donar resposta a situacions de salut complexes. La infermeria, al llarg dels anys, s'ha anat adaptant als nous reptes, i els seus coneixements i habilitats pràctiques s'han incrementat exponencialment, cosa que ha contribuït a millorar la qualitat i la rendibilitat dels serveis del salut ${ }^{200}$, els quals busquen maneres de treballar, estratègies i estructures més cost-efectives per proporcionar una pràctica infermera basada en l'evidència que sigui segura i competent ${ }^{201}$. Mai com ara havia estat tan essencial per als professionals de la infermeria ser aprenents actius i durant tota la seva vida laboral ${ }^{202}$.

En alguns països, com els EUA, el Canadà, Australia o el Regne Unit, va sorgir fa uns quaranta anys una figura en infermeria amb nivell de màster que la qualificava per assumir competències clíniques més avançades, anomenada infermera de pràctica avançada (IPA) ${ }^{203,204}$. EI 
terme infermera de pràctica avançada s'ha utilitzat àmpliament per descriure la pràctica de la infermera clínica especialista i costa trobar-ne una definició clara, així com definir el significat que s'entén per pràctica especialitzada. Això ha donat lloc a discussions sobre la necessitat d'aclarir la pràctica d'infermeria avançada com a primer pas per al disseny del seu currículum formatiu ${ }^{205} \mathrm{i}$, a la vegada, del seu marc competencial ${ }^{206}$.

En els països on la formació i el reconeixement de la infermera de pràctica avançada o especialista és un fet, encara es lluita per la implementació del seu rol. Això pot produir dificultats en la introducció de nous rols ${ }^{207}$ o fins i tot en la determinació de qui és una infermera generalista o una infermera especialista ${ }^{202}$.

Segons el Diccionari de la Llengua Catalana, la paraula generalista referent a les professions s'aplica a aquell professional que té coneixements generals de diverses matèries i cobreix tot un sector d'activitat, mentre que especialista és la persona que es dedica a una branca determinada de la ciència i en té coneixements profunds. Segons aquesta definició, la infermera especialista és la que després de la seva formació com a infermera ha concentrat el seu focus de coneixements i habilitats en les necessitats específiques d'un grup de pacients.

A la literatura es troben diverses definicions d'infermera clínica especialista o de pràctica avançada. Als anys noranta, Bousfield ${ }^{208}$ va descriure la infermera clínica especialista (ICE) com «un professional expert en el qual la seva posició influeix en l'atenció al pacient a través del seu coneixement avançat, la seva experiència i capacitats de lideratge, en un entorn multidisciplinari», és a dir, un professional a qui la seva formació el capacita per liderar tant la cura del pacient com l'organització de l'atenció. Qui aporta una definició més completa i que a més té en compte els diferents models d'organització sanitària en què aquesta figura exercirà les seves funcions és el Consell Internacional d'Infermeria (CIE) ${ }^{209}$, que la descriu com «una infermera titulada que ha adquirit la base de coneixements d'expert, habilitats per a l'adopció de decisions complexes i les competències clíniques necessàries per desenvolupar un exercici professional ampli. Les característiques d'aquestes competències vindran donades pel context o el país en què la infermera estigui acreditada per exercir».

El problema amb la definició també ha comportat problemes a l'hora d'establir-ne les competències. Així doncs, diversos autors han sostingut que la manera d'entendre la pràctica avançada de la infermeria és a través de la descripció d'una sèrie de competències integrades en una àmplia varietat de funcions (subrols), en lloc de només funcions concretes ${ }^{210,202}$. En aquesta definició de subrols també hi ha diferències, però els subrols més importants establerts per a la pràctica experta o d'alt nivell descrits per alguns autors són²11,212,213:

- Rol de pràctica experta: Proporcionar atenció directa al pacients, també de manera indirecta col-laborant amb altres membres de l'equip o participant en el disseny i la implementació de programes educatius, així com ajustar tractaments, prescriure medicacions o sol-licitar proves complementàries. 
- Rol educador: Educar pacients, familiars, professionals i públic en general.

- Rol consultor: Ser referent per a la institució, pacients, familiars o altres professionals.

- Rol investigador: Practicar la recerca com a investigador principal o associat.

- Rol gestor o administrador: Participar en la gestió administrativa o econòmica i de la planificació dels programes educatius, així com identificar mancances en els serveis per a l'atenció a la DM.

- Rol col·laborador, comunicador o d'enllaç: Coordinar recursos i serveis per a l'atenció a la DM i coordinar la relació entre equips i nivells assistencials.

- Rol innovador: Detectar i avaluar necessitats de canvi, identificar noves maneres d'assistència i col·laborar en la implementació de nous models d'atenció.

Tenint en compte que la ICE s'ha de definir d'acord amb les seves competències i que aquestes dependran de les singularitats del lloc o país on ha d'exercir, al 2008 la National Association of Clinical Nurses Specialists ${ }^{214}$ va definir la infermera de pràctica avançada com aquella que «té la capacitat d'aplicar una àmplia gama de competències clíniques i pràctiques basades en la investigació, dins d'una àrea determinada de la infermeria ${ }^{215}$, i va establir un marc competencial per a la infermera clínica especialista, independentment de l'especialitat i el lloc on exerceix, amb el compromís de revisar-lo cada cinc anys. Estableix 7 tipus de competències que segueixen el model de Sparacino ${ }^{216}$ :

1. Competències referents a la cura directa al pacient: Interacció directa amb els pacients, famílies o grups de pacients per tal de promoure la salut o el benestar i la qualitat de vida. Es caracteritza per una visió holística de la salut i els estats de malaltia.

2. Competències en relació amb el rol de consultor: Adreçat al pacient, els professionals i el sistema sanitari. Aquest rol és reconegut per tenir coneixements especialitzats que ajuden a la resolució de problemes.

3. Competències de lideratge: Capacitat de gestionar el canvi, apoderar altres professionals, influir en la pràctica clínica, dins i fora del sistema sanitari.

4. Competències en relació amb el rol de colllaborador: Treballar en equip per optimitzar els resultats clínics dels pacients, a més de col·laborar amb la família i amb l'organització o el sistema sanitari.

5. Competències relacionades amb l'educació: Capacitats per educar els pacients, les famílies, grups de pacients i altres professionals. 
6. Competències relacionades amb la investigació: Fer recerca rigorosa i de forma sistemàtica relacionada amb la interpretació i l'ús de l'evidència en la pràctica clínica i la millora de la qualitat, així com participar de forma activa en projectes d'investigació.

7. Competències en relació amb l'ètica, la moral i la defensa tant dels pacients com de la família, l'equip sanitari, l’organització, el sistema de salut i la comunitat.

Molts d'aquests rols es veuen solapats pels d'una infermera generalista, per la qual cosa el principal debat rau a clarificar els rols i les competències dels diferents col-lectius per tal de preparar el seu desenvolupament professional, però aquest problema no està resolt. Aquesta falta de claredat en el rol dona lloc a un conflicte o ambigüitat del rol. El conflicte de rol es dona quan el professional veu o percep que múltiples requisits del treball que desenvolupa són incompatibles amb la seva formació o que comparteix les mateixes o similars responsabilitats amb d'altres ${ }^{217}$.

Diversos estudis que han intentat esbrinar els motius pels quals existeix aquesta ambigüitat en el rol de la ICE conclouen que els títols inconsistents, el no establiment d'objectius per a la funció de la ICE, la manca d'entesa de la funció de la ICE per part d'altres professionals de la salut o la falta de suport institucional han contribuït a l'ambigüitat del rol ${ }^{218}$. Aquesta s'associa sovint a resultats negatius en el personal, els pacients i la institución ${ }^{19}$.

Malgrat totes aquestes controvèrsies en la definició de rols i competències, els estudis suggereixen que la influència de la infermera clínica especialista en una àrea determinada ha demostrat que pot establir millores significatives en la qualitat de la cura i la seguretat del pacient, així com reduir ingressos als serveis d'urgències dels hospitals i disminuir també les despeses sanitàries ${ }^{220,221,222}$.

Els estudis que han analitzat el rol de la infermera especialista en DM també han mostrat indefinició i poca concreció en els rols i les competències de les infermeres especialistes en DM, a la vegada que els mateixos professionals tenen poc interioritzat el seu rol. Un estudi a Suècia va analitzar la percepció de les infermeres especialistes en DM sobre el seu rol professional223. Elles mateixes es descriuen com a professionals:

- Experts: tant en formació clínica com en habilitats per educar els pacients.

- Motivadors: pel que fa a aconseguir canvis en l'estil de vida i a mantenir-los, així com a ajudar en l'autocontrol de la malaltia.

- Líders: quant a la capacitat de coordinar l'atenció a la DM dins d'un equip interdisciplinari.

- Directors o executius: per la seva feina burocràtica, com és seguir les guies de pràctica clínica, la introducció de dades o l'elaboració de documents.

- Modèlics: en relació amb el seu propi estil de vida, perquè ha de ser un exemple per als pacients. 
Un altre estudi al Regne Unit atribueix a una infermera especialista en malalties cròniques 5 tipus de rols 224 :

1. Educador: educar els pacients, les famílies, la comunitat i altres professionals.

2. Intèrpret: ajudar els pacients a entendre i trobar significat a la seva malaltia i a l'atenció que reben.

3. Monitor: revisar els canvis i els efectes del tractament.

4. Modulador: canviar o ajustar les teràpies.

5. Referent: derivar els pacients a altres professionals o serveis.

Una revisió sistemàtica recent ${ }^{225}$, en què l'objectiu era identificar el rol de la infermera especialista en DM com una estratègia de millora i aclarir la seva participació en les cures integrals del pacients amb DM, va detectar 7 dominis de responsabilitat: 1) pràctica clínica, 2) control de la malaltia, 3) prescripció i suport en l'autocura, 4) educació, 6) prevenció de complicacions i 7) rol d'enllaç, que es refereix a la capacitat que té la infermeria especialista en DM de derivar els pacients a altres professionals. Però hi ha pocs estudis que mostrin com s'integra el rol de la infermeria especialista en DM dins l'equip multidisciplinari.

Tot i haver-hi aquesta heterogeneïtat en la implementació de la infermera especialista en DM, diversos estudis han avaluat l'eficàcia de l'educació terapèutica impartida per infermeres especialistes en DMM en diferents aspectes del control de la malaltia, i han mostrat uns resultats positius en relació amb la infermeria especialitzada ${ }^{226,227}$; amb tot, la qüestió és si el nivell assolit es manté al llarg del temps, ja que igual que passa als estudis sobre l'efectivitat de l'ET, hi ha pocs estudis que avaluïn resultats després de 6 o 12 mesos $^{228}$. En general, no hi ha massa estudis de bona qualitat que donin suport als rols de la infermeria especialitzada en DM, cosa que seria especialment desitjable per justificar que aquests llocs de treball es prevegin dins el sistema sanitari, el qual es mou en una cultura d'estalvi i eficiència ${ }^{229}$.

Només un estudi, en què hi van participar vuit països europeus, entre els quals Espanya, va analitzar el perfil professional de les infermeres en DM en diferents nivells d'atenció, primària i especialitzada, basant-se en 7 tipus de subrols ${ }^{230}:$ 1) pràctica clínica experta, 2) educador, 3) assessor o consultor, 4) investigador, 5) director o administrador, 6) col·laborador o enllaç i 7) innovador. Aquest estudi va demostrar que a Espanya les infermeres tenen més competències en el camp de l'educació que les europees, i que estan més diferenciades les relacionades amb l'alimentació i la cura del peu, perquè en altres països la figura de la dietista i el podòleg està més integrada en els equips.

En l'APS, alguns països han substituït el metge per la IPA i els resultats han estat concloents en el fet que les infermeres amb una formació adequada són capaces de proporcionar resultats de salut i qualitat d'atenció, rendibilitat i ús dels serveis de forma equivalent o superior als que aporta l'atenció mèdica ${ }^{231,232}$. 


\subsection{Marc assistencial de la diabetis a Catalunya. El paper de la infermera}

Catalunya disposa d'una extensa xarxa assistencial desplegada en tot el territori, formada per diferents tipus de centres que donen cobertura a les necessitats de salut dels ciutadans. Les persones amb DM poden ser ateses tant a l'APS com a l'AE.

\subsubsection{Descripció dels diferents nivells d'atenció}

\subsubsection{Xarxa d’atenció primària de salut}

L'APS és el primer punt d'accés dels ciutadans a l'atenció sanitària. Els serveis es troben a cada centre d'atenció primària (CAP), on treballen els equips de professionals d'atenció primària de salut (EAP). El CAP és el primer lloc on cal anar quan es té un problema de salut o quan es vol prevenir alguna malaltia. Ofereix assistència sanitària i social, a més de serveis de promoció de la salut i d'atenció preventiva, curativa i rehabilitadora. En alguns centres també hi ha consultes d'AE i serveis de diagnòstic per la imatge.

L'organització sanitària assigna a tota la població un CAP de referència amb un EAP, segons el lloc de residència. L'EAP és el conjunt de professionals de medicina de família, pediatria, infermeria, odontologia, treball social i d'atenció al ciutadà, preparat per oferir una atenció integral que inclou l'atenció i la promoció de la salut i l'educació en els hàbits saludables, la prevenció de malalties i l'orientació en l'assistència social ${ }^{233}$.

L'APS és una peça fonamental del sistema sanitari, que té la missió de proporcionar una atenció sanitària integral al pacient dins del seu entorn familiar i comunitari i, per tant, és el nivell on es resolen gran part dels problemes de salut de les persones. En general, a Catalunya, com a la majoria de països, la DM2 és tractada a l'APS. Al 2006, quan la prevalença estimada de DM era del $10 \%$, un estudi ja va demostrar que era el problema de salut que generava més demanda i que consumia més temps a les consultes d'infermeria d'aquest àmbit ${ }^{234}$.

La infermeria de I'APS té una posició privilegiada per detectar precoçment els canvis socials i les noves demandes. Per tant, pot avançar-se i adequar-se a les noves realitats. La missió de la infermeria d'APS és repartir els recursos de què disposa, sempre escassos, entre molts pacients, de forma eficient, equitativa i prioritzada, procurant ser el més resolutiu possible en el cas de malaltia o de la seva prevenció. Els nous reptes sanitaris actuals, com la cronicitat i l'envelliment, fan que la infermera adquireixi un major protagonisme i un paper inqüestionable de lideratge ${ }^{235}$.

Actualment, des que es va incorporar com a especialitat de la infermeria la Infermeria Familiar i Comunitària, conviuen en aquest àmbit infermeres generalistes, és a dir, infermeres diplomades o graduades, amb aquelles que han obtingut l'esmentada especialitat, i comparteixen en la majoria de centres les mateixes funcions, ja que tot i que l'especialitat està reconeguda des del 2005 i s'està fent formació des del 2011, encara no s'ofereixen places amb aquesta categoria a l'APS ${ }^{236}$. 
A Catalunya, el document Aportació de la infermera a l'atenció primària de salut ${ }^{237}$ que es va elaborar per donar a conèixer i permetre el desenvolupament de les competències i capacitats dels professionals d'infermeria que ofereixen els serveis a la població en el marc de l'APS, manifesta, entre molts altres aspectes, que:

Tot i l'àmplia formació de les infermeres en salut pública i comunitària, aquelles que treballen actualment en els equips de salut encara no han pogut incloure de manera efectiva la dimensió comunitària en els llocs de treball, cosa que ha obligat a moltes a adaptar-se a concepcions mecanicistes i biologistes marcadament medicalitzades.

Actualment encara hi ha dificultats per integrar amb normalitat les intervencions preventives a la pràctica infermera.

Les persones encara no han visualitzat la infermera d'APS com l'element de referència i agent de salut i, d'altra banda, els i les professionals de la infermeria encara prioritzen les accions relacionades amb la curació i l’administració terapèutica.

\subsubsection{Xarxa d’atenció especialitzada}

L'AE de salut és el segon nivell d'accés dels ciutadans a l'atenció sanitària. L'AE i hospitalària als pacients es presta a través de la xarxa hospitalària d'utilització pública, que està desplegada per tot el territori català. Els serveis que s'ofereixen als hospitals d'aguts són ${ }^{238}$ :

1. AE ambulatòria (consultes externes)

2. Internament

3. Urgències

4. Hospital de dia

5. Intervencions quirúrgiques amb ingrés o sense

6. Proves diagnòstiques

Quant al paper de la infermeria en l'AE, només està regulat per a aquelles especialitats aprovades pel Reial Decret 450/2005, sobre especialitats d'infermeria ${ }^{239}$. No hi ha estudis a Catalunya en què es defineixi el paper dels professionals d'infermeria que treballen en l'àmbit de l'AE en DM, sigui en els serveis d'endocrinologia dels hospitals o en els centres ambulatoris d'AE. Una subanàlisi de l'estudi SEND ${ }^{240}$ va comparar la formació i els rols entre la infermeria de l'APS i la de l'AE, i es va observar que els professionals d'infermeria de l'AE tenen més formació en totes les àrees relacionades amb la DM (fisiopatologia, nutrició i ET). El rol d'educador, tant del pacient com de la família i d'altres professionals, el rol investigador i el de consultor estan també més presents en l'AE que en l'APS. 


$$
4
$$




\section{JUSTIFICACIÓ DE LA INVESTIGACIÓ}

Com s'ha comentat en apartats anteriors, el tractament de la DM és extremadament complex i el pacient és el principal responsable del control de la malaltia. Perquè el pacient i la seva família puguin dur a terme totes les exigències que els imposa la malaltia, és imprescindible que els professionals de la salut apliquin programes educatius estructurats que facilitin l'autogestió de la malaltia i enforteixin el seu potencial. Això comporta un alt grau d'especialització i una formació continua dels professionals, a més d'una estructura sanitària que ho faciliti. Tradicionalment, la formació específica en DM dels professionals no està inclosa en els currículums formatius de cap de les carreres sanitàries.

Les organitzacions sanitàries consideren l'AP com el principal lloc d'atenció per a les persones amb DM2, i l'AE, generalment ubicada als hospitals, per a les persones amb DM1 o DM2 amb molta pluripatologia i tractaments complexos.

Catalunya va ser, fa més de trenta anys, una de les comunitats autònomes pioneres a implantar programes d'ETD, donar formació als professionals de les diferents disciplines que intervenen en el seu tractament i fomentar, a través d'aquesta formació, el treball de l'equip interdisciplinari i la creació d'unitats especialitzades per al tractament de la DM.

Els cursos de formació en DM i ET organitzats per l'Institut d'Estudis de la Salut (IES) als anys vuitanta, liderats per alguns diabetòlegs motivats per trobar noves maneres d'ensenyar els pacients, van desaparèixer quan ja hi havia un gran nombre de professionals formats arreu de Catalunya, majoritàriament infermeres, les quals es van distribuir en unitats especialitzades dels hospitals de referència i també a CAP, amb un títol no reconegut d'«educador en diabetis». Aquestes places van desaparèixer amb la reforma de l'AP als anys noranta.

Des de llavors, la formació en DM i en ET, a Catalunya, ha estat basada en cursos de formació continuada, la majoria promoguts, finançats o subvencionats per la indústria farmacèutica o per les institucions, i en un màster de títol propi de la Universitat de Barcelona. Aquesta formació ha estat voluntària, no vinculant per obtenir un lloc de treball en una unitat de DM especialitzada, i no està reconeguda per les organitzacions sanitàries, fet que pot comportar una gran desigualtat en l'assistència, de manera que es difícil diferenciar les competències que han de tenir els professionals en els diferents nivells d'atenció.

No hi ha cap estudi al nostre país que valori d'una forma global la formació en DM dels professionals de la infermeria i del rol que desenvolupen dins l'equip, i tampoc hi ha hagut interès a establir una diferenciació del rol per a la pràctica més avançada o experta dels qui treballen en unitats especialitzades. 
És important saber quina és aquesta situació per tal d'establir sistemes de millora en la formació, desenvolupar el rol professional de la infermeria que ha de tenir cura de les persones amb DM, així com per justificar un model d’atenció sanitària més equitatiu en què l’ET es vegi com una necessitat dels pacients i un deure dels professionals.

La realització d'aquest estudi neix amb l'objecte principal de conèixer l'evolució del model d'atenció a la DM a Catalunya, des d'un punt de vista de desenvolupament de programes d'ET, formació dels professionals, metodologia de treball i desenvolupament del rol dels professionals de la infermeria que imparteixen l'educació, tant en l'àmbit de l'AP com de l'AE.

La primera part d'aquesta investigació analitza l'evolució de l'ET a Catalunya mitjançant un seguit de fons escrites ordenades de manera cronològica i de fonts orals amb entrevistes a les persones que van participar com a principals protagonistes en la implantació de l'ET a Catalunya, i la seva percepció sobre la seva solidesa, fet que justifica el mètode d'investigació històrica i l'anàlisi qualitativa.

\subsection{Investigació històrica}

La investigació històrica es realitza quan es vol estudiar una realitat des d'una perspectiva històrica buscant tant les fonts primàries com les secundàries per tal de reconstituir uns fets ${ }^{241}$

El mètode d'investigació històric és l'analítico-sintètic. Quan s'estudien qüestions històriques s'han d'analitzar els fets descomponent-los en totes les seves parts per conèixer les possibles arrels socials, econòmiques, religioses, polítiques o etnogràfiques, i a partir d'aquesta anàlisi fer una síntesi que reconstitueixi el fet històric.

El mètode analític és l'heurístic. Aquesta paraula ve del terme grec heurisko, que vol dir «jo busco» o «jo descobreixo», i per a la investigació històrica es referiria a buscar en fonts escrites o bé orals, com poden ser les entrevistes a personatges que han participat d'alguna manera en el fet que volem estudiar. El mètode de síntesi és l'hermenèutic, paraula que prové del terme grec hermeneuo, que vol dir «jo explico».

La investigació històrica també és deductivo-inductiva. Deducció ve del llatí deductio, que vol dir «treure conseqüències d’un principi, proposició o supòsit». S'utilitza per referir-se al mètode de raonament que porta del que és general al que és particular. Aquest mètode és fonamental en la investigació històrica, ja que, per exemple, no es podria entendre la història de la ciutat de Barcelona si no expliquéssim la història de Catalunya i Espanya. Inducció ve del llatí inductio, que vol dir "persuadir», «instigar». S'utilitza per anomenar el mètode de raonament que assegura la possibilitat de passar d'allò particular a allò general. Per tant, el mètode d'investigació històrica ha de passar d'allò general a allò particular, però ha de ser completat del que és particular al que és general. 
Entre els principals submètodes d'investigació històrica hi ha el cronològic, el geogràfic i l'etnogràfic. Cronologia ve del nom grec cronos, que és el déu del temps. En tota investigació històrica és imprescindible conèixer el desenvolupament dels fets per ordre successiu de dates. El submètode geogràfic és el que tracta els fets per ordre de pobles. I el submètode etnogràfic és el que relaciona els fets històrics per races, religions, nacionalitats o manifestacions culturals, entre d'altres factors.

Entre les fonts de les quals es nodreix la història hi ha els escrits o documents que constitueixen el que anomenem fons escrites i que són les més importants. En la història de la medicina els principals documents són els llibres, els articles mèdics i els fullets. Els testimonis són les fonts orals i segueixen a l'escriptura en ordre d'importància, però no serveixen com a úniques fonts per escriure la història, ja que només són una guia per a la recerca de documents imprescindibles.

\subsection{Investigació qualitativa}

L'enfocament qualitatiu és el mètode que ofereix millors oportunitats per comprendre i entendre el procés de vida que les persones han pogut experimentar respecte d'algun fenomen en el qual han participat com a protagonistes ${ }^{242}$.

La investigació qualitativa es planteja des del constructivisme. Hi ha diferents punts en els quals coincideixen ambdós plantejaments: un d’ells és la importància que donen a la interpretació com a vehicle de coneixement, assumint que la persona elabora les seves percepcions i, per tant, interpreta des de les seves categories i organitza la realitat des dels seus significats. Així, davant una experiència nova la persona comprendrà i integrarà en coherència amb les experiències anteriors i amb la seva manera de donar sentit al món que està vivint. Un altre punt de coincidència amb el constructivisme és el d'assignar el valor que li correspon a allò subjectiu (del subjecte) i a les emocions, en l'acte de construir el coneixement. Cada estímul passa a través del subjecte en l'acte de conèixer i cada experiència passa el filtre personal, raó per la qual es converteix en una experiència del subjecte. Les emocions creen l'escenari des d'on la persona construeix les seves cognicions, de forma que si l'estat emocional canvia, també canviarà la manera de veure i avaluar una experiència ${ }^{243}$.

La investigació qualitativa involucra l'anàlisi de les paraules i se centra en la comprensió de la globalitat, i també explora la profunditat la riquesa i la complexitat inherent a un fenomen. L'objecte de la investigació qualitativa és revelar la subjectivitat, és a dir, la manera com les persones que participen donen sentit a les seves experiències, de forma que el mostreig se centra més en les experiències, els esdeveniments i les situacions que en la quantitat de persones participants. Només cal que l'investigador s'interessi per seleccionar subjectes capaços de proporcionar una àmplia informació sobre l'experiència o les situacions que s'estudien ${ }^{244}$. 
Les persones que participen atorgant informació s'anomenen participants o informants, i poden presentar-se voluntàriament o bé ser seleccionats per l'investigador atenent als coneixements particulars, experiències o opinions relacionades amb l'estudi ${ }^{242}$.

Actualment, la investigació qualitativa disposa d'una gran quantitat de models, de mètodes, de tècniques de recol·lecció i anàlisi de dades, per a qualsevol tipus d'anàlisi qualitativa. Té com a denominador comú la preocupació per transformar i interpretar les dades qualitatives de manera acadèmica i rigorosa, amb la finalitat de captar la complexitat dels mons socials que s'intenten comprendre. Els instruments de recol·lecció de dades més utilitzats són l'entrevista i la història de vida, eines que permeten revelar la pròpia singularitat del subjecte ${ }^{245}$. 


$$
0
$$

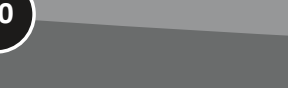




\section{OBJECTIUS}

Aquest estudi s'ha dut a terme en dues fases i per cadascuna d'elles s'han treballat objectius diferents:

\section{Primera fase de l'estudi Objectiu general:}

1) Explorar com es va construir la estructura de les unitats de diabetis i d'Educació Terapèutica des del punt de vista dels professionals que van ser referents en el seu començament i desenvolupament.

\section{Objectius específics:}

- Identificar els elements que van motivar la introducció de l'ET en el nostre medi.

- Explorar l'impacta de la formació dels professionals en el desenvolupament dels programes d'ET.

- Analitzar la influencia del canvi de la reforma del sistema sanitari a Catalunya i altres factors que han influït en la implementació de l’ET i en la situació actual.

- Conèixer la opinió dels professionals sobre els factors que han d'afavorir u obstaculitzar l'evolució de l’ET a Catalunya.

\section{Segona fase de l'estudi}

\section{Objectiu general:}

2) Descriure el grau d'implementació de l'Educació Terapèutica a Catalunya i la formació específica en diabetis, nutrició i educació terapèutica dels professionals que la imparteixen.

\section{Objectius especifics:}

- Identificar el grau de formació en diabetis dels professionals dels diferents nivells d'atenció (primària/especialitzada).

- Analitzar el tipus d'ET individual o grupal i estructurada o no estructurada que es realitza als centres tant d'atenció primària com especialitzada.

- Descriure l'àmbit d'aplicabilitat dels programes d'ET.

- Determinar la relació entre el grau de formació dels professionals i el tipus d'ET proporcionada.

- Definir el desenvolupament del rol professional d'infermeria en l'atenció a les persones amb diabetis tant a l'assistència primària com a l'assistència especialitzada.

- Identificar el grau de satisfacció laboral dels professionals d'infermeria que atenen a les persones amb diabetes. 


\section{DISSENY I METODOLOGIA DE LA INVESTIGACIÓ}

\subsection{Primera fase de l'estudi}

Disseny: estudi qualitatiu històric descriptiu.

Població d'estudi: es va utilitzar una mostra intencionada (mostreig per criteri) de professionals de l'àmbit mèdic, de la infermeria i de l'administració sanitària que van estar implicats de manera activa en el procés d'organització i implementació de l'ET a Catalunya als anys setanta i vuitanta. Es va contactar amb aquests professionals informants telefònicament o mitjançant el correu electrònic per tal sol-licitar-los la participació en una entrevista semiestructurada adaptada als objectius de l'estudi. El nombre d'informants es va limitar, ja que la seva elecció estava condicionada per l'experiència que van tenir en la implantació de l'ET a Catalunya.

Tècnica de recollida d'informació: es van fer entrevistes semiestructurades als professionals participants (Annex 1).

Es va dur a terme una revisió bibliogràfica de publicacions i comunicacions a congressos derivades dels resultats de l'aplicació de programes d'ET a Catalunya, una revisió històrica de documents corporatius o associatius, dels cursos de formació, d'actes de l'Associació Catalana de Diabetis i de l'antiga Associació d'Educadors en Diabetis, així com també una revisió de I'hemeroteca de publicacions a diaris sobre diferents activitats relacionades amb l'educació de persones amb diabetis organitzades per associacions de pacients o per professionals.

Instruments de recollida d'informació:

- Gravadora per enregistrar les entrevistes.

- Documents històrics que es van obtenir a partir de la sol-licitud a persones del Consell Assessor de la Diabetis de Catalunya i a persones responsables dels cursos de formació.

- Documents de premsa escrita.

- Actes de reunions de la Junta de l'Associació Catalana d'Educadors en Diabetis (ACED) i de l'Associació Catalana de Diabetis (ACD).

- Llibres de resums (abstracts) dels congressos de l'ACED i de l'ACD.

- Documents de les activitats organitzades per diferents àrees sanitàries. 
Tots els documents es van organitzar en diferents capetes en funció dels continguts.

Anàlisi de les dades: les entrevistes van ser gravades amb el previ consentiment verbal dels entrevistats, de cara a la posterior anàlisi, i es van guardar en carpetes individuals amb el nom de cada informant.

El procés d'anàlisi es va realitzar de forma manual. El primer que es va fer és transcriure totes les entrevistes a fi de poder-les analitzar posteriorment.

L'anàlisi de la informació es va organitzar en tres fases seguint el model de Miles i Huberman. A la primera es van fer lectures repetides de les dades per tal d'identificar els conceptes i les unitats de significat que apareixien als textos. Durant aquesta primera anàlisi es van realitzar notes i memos de la investigadora per descriure les primeres intuïcions, idees o interpretacions que van sorgir de les dades. En aquesta fase es va fer la fragmentació del text en unitats d'anàlisi, i es va contrastar amb les categories construïdes per verificar si podia ser inclosa o si s'havia de crear una nova categoria.

El procés de categorització va finalitzar quan no es van trobar noves informacions que permetessin crear noves categories.

A la segona fase es van analitzar les categories per separat, es van fer comparacions i relacions entre les categories i, finalment es van classificar en grups temàtics (metacategories).

A la tercera fase es va dur a terme la integració i la interpretació de les dades.

\subsection{Segona fase de l'estudi}

Àmbit de l'estudi: Catalunya.

Hipòtesi: la implantació de l'ET a Catalunya es un fet, però hi ha una desigualtat en la formació dels professionals, en el recursos i en la planificació i avaluació dels programes educatius.

Població d'estudi: professionals d'infermeria de l'àmbit de l'assistència primària i l'assistència especialitzada de la comunitat autònoma de Catalunya.

Disseny de l'estudi: estudi descriptiu, transversal i comparatiu.

Període de recollida d'informació: va començar el mes de setembre del 2014 i va finalitzar al setembre de 2015. 
Criteris d'inclusió: professionals d'infermeria de l'assistència primària dedicats a l'atenció de pacients amb diabetis i de l'assistència especialitzada en les unitats d'endocrinologia i diabetis dels hospitals, que acceptesin de participar-hi.

Criteris d'exclusió: professionals d'infermeria l'activitat professional dels quals no inclogui l'atenció a les persones amb diabetis. Als centres d'assistència primària es van excloure les infermeres de pediatria, atès que la diabetis tipus 1 en pediatria es controla als hospitals amb unitats d'endocrinologia pediàtrica, els adjunts a la direcció lliures d'activitat asistencial i les llevadores.

\section{Variables:}

1. La formació en diabetis dels professionals d'infermeria (cursos de formació continuada, formació de postgrau).

2. Els nivells d’atenció (assistència primària, assistència especialitzada).

3. Treball (tipus de prestacions, organització i procés de treball).

4. Avaluació de resultats i registre de dades de la pràctica assistencial.

5. Rol professional (de pràctica clínica, educador, assessor, director o líder, col·laborador, investigador i innovador).

6. Satisfacció laboral.

\section{Càlcul de la mostra:}

Assistència especialitzada: es van incloure tots els professionals dedicats a l'educació terapèutica en diabetis dels hospitals que disposen de servei d'endocrinologia.

Assistència primària: es va seleccionar una mostra de professionals que atenen pacients amb diabetis i que desenvolupen la seva activitat als CAP. En una primera etapa es va realitzar un mostreig per conglomerats (àrees bàsiques de salut, ABS). De les 364 ABS existents a Catalunya l'any 2014, se'n van seleccionar aleatòriament 97 . En una segona etapa es va recollir informació de tots els professionals d'aquests centres que van participar voluntàriament en l'estudi. Donada la impossibilitat de disposar d'un un llistat de tots els professionals que potencialment es podien incloure a l'estudi (infermeres que atenen pacientes amb diabetis) per a cadascuna de les ABS, es va estimar, desprès d'estudiar els resultats de les primeres mostres pilot, un nombre de tres professionals per centre. En finalitzar la recollida de dades es van recalcular les ponderacions fruit del disseny del mostreig i la resposta obtinguda de cadascun dels centres. Aquestes ponderacions es van incloure a la base de dades final per tal de fer-les servir en les posteriors anàlisis de dades. 


\section{Instruments de recollida d'informació:}

Per a aquest estudi es va fer una adaptació del qüestionari utilitzat en l'estudi SEND ${ }^{229}$, validat a la llengua castellana, que consta de 39 preguntes repartides en 4 apartats:

1. Estructura: lloc de treball, formació académica i càrregues de treball.

2. Procés: tipus de prestacions i grau de realització del rol professional.

3. Resultats de la pràctica assistencial: avaluació i registre de dades.

4. Grau de satisfacció laboral.

Es van fer canvis a les preguntes referents a l'estructura (lloc de treball i formació académica) i al procés (tipus de prestacions) per adaptar-la als objectius de l'estudi. Un cop fets els canvis es va passar a un grup pilot de 10 professionals per valorar-ne l'aplicabilitat.

El qüestionari definitiu consta d'una primera part informativa sobre el propòsit de l'estudi i 39 preguntes (Annex 2). D’aquestes, 25 es refereixen a l'estructura, tipus de prestacions, organització i procés del treball, i 4 són relatives a l'avaluació de resultats i el registre de dades de la pràctica assistencial. Es valora el rol de pràctica clínica experta (14 ítems) i també els 6 components que defineixen les activitats del rol d'una infermera clínica especialista: educador (10 ítems), consultor (9 ítems), investigador (11 ítems), director o líder (5 ítems), col·laborador (4 ítems) i innovador (5 ítems). Als participants se'ls pregunta sobre la freqüència amb què realitzen cada una de les activitats descrites, en una puntuació d'1 a 5 de l'escala de Likert (en què 1 = mai i $5=$ sempre). Hi ha també una pregunta relacionada amb la satisfacció laboral, que consta de 16 ítems valorats mitjançant una puntuació de l'1 al 5 de l'escala de Likert (on 1 = gens satisfet $\mathrm{i} 5$ = molt satisfet). Finalment, hi ha un espai per a observacions $\mathrm{i}$ un altre per fer propostes de millora en relació amb l'educació terapèutica.

\section{Mètode de recollida d'informació a l'assistència especialitzada:}

1. En primer lloc, es va obtenir del Servei Català de la Salut el llistat d'hospitals d'aguts de la xarxa de centres d'internament d'utilització pública de Catalunya a través de la pàgina:

http://www.urv.cat/media/upload/arxius/borsa_treball/Practiques/llistat_hospitals.pdf. S'hi van afegir dos hospitals que, tot i no estar inclosos a la xarxa d'utilització pública, disposen de servei d'Endocrinologia amb professionals d'infermeria dedicats a l'educació de pacients amb diabetis (Hospital de Nens de Barcelona i Hospital General de Catalunya). 
2. Es va dur a terme un contacte telefònic amb la direcció d'infermeria o mèdica de tots els hospitals per saber si disposaven de servei d'Endocrinologia i Nutrició amb professionals d'infermeria dedicats a l'ET de pacients amb diabetis. Posteriorment, es va enviar a les direccions d'infermeria una carta informativa de presentació de l'estudi (Annex 3) i el document d'aprovació del Comitè d'Ètica d'Investigació Clínica (CEIC) (Annex4).

3. Després es va telefonar als professionals educadors per explicar-los el propòsit de l'estudi i demanar-los la col·laboració per respondre el qüestionari, així com la seva adreça de correu electrònic. Als qui acceptaven se'ls enviava via correu electrònic la carta informativa, el document d'aprovació del CEIC i el qüestionari, amb el compromís de retornar-lo també per correu electrònic dins el termini de dues setmanes.

\section{Mètode de recollida d'informació a l'assistència primària:}

1. Es va obtenir del Departament de Salut un llistat de totes les Àrees Bàsiques de Salut (ABS) de Catalunya.

2. Es va contactar telefònicament amb les adjuntes d'infermeria de les ABS seleccionades per explicar-los el propòsit de l'estudi i demanar-los la col-laboració de les infermeres del centre. A les qui acceptaven se'ls enviava via correu electrònic la carta informativa i de presentació específica per als adjunts o directors de les ABS (Annex 5), el document d’aprovació del CEIC i el qüestionari amb el compromís de retornar-lo, també per correu electrònic, en el termini de dues setmanes. Als dos i sis mesos es va enviar novament un recordatori als adjunts d'infermeria d'aquells centres dels quals no s'havia obtingut cap resposta.

3. Les respostes obtingudes es van introduir en una base de dades SPSS que es va confeccionar amb les variables del qüestionari.

\section{Anàlisi de les dades:}

Es va dur a terme una anàlisi descriptiva de les variables d'interès, en què es proporcionaven freqüències i percentatges per a les variables qualitatives i mitjanes, i les desviacions típiques per a les variables quantitatives, a més dels corresponents intervals de confiança al $95 \%$. Com que es va treballar amb un disseny mostral complex, els estadístics descriptius es van proporcionar ponderats i sense ponderar, per tal de visibilitzar les característiques de la mostra recollida i la correcció de les estimacions, conseqüència de l'efecte del disseny mostral.

Per comparar les dades entre l'assistència primària i l'especialitzada es va crear una nova variable, el «tipus d'atenció», de forma que en l'especialitzada es van incloure només professionals 
que a la pregunta sobre quin era el seu rol principal van marcar les opcions «Infermera experta en diabetis en consultes externes d'hospital» i «Infermera experta en diabetis en hospital», mentre que a l'atenció primària es van incloure aquells que van marcar les opcions «Assistència primària» $\mathrm{i}$ "Infermera experta en diabetis en centre d'especialitats», ja que només es van enviar qüestionaris als hospitals i als centres d'assistència primària.

Quant a l'estudi de possibles associacions bivariades entre variables qualitatives, es va utilitzar la correcció per a disseny complex de la prova khi quadrat de Rao-Scott. Per a l'estudi d'associacions bivariades entre variables quantitatives i qualitatives es van utilitzar les proves $t$ de Student de comparació de mitjanes per a mostres independients i ANOVA, depenent del nombre de grups que calia comparar. En el cas d'associacions entre dues variables quantitatives, es van realitzar anàlisis de regressió lineal simple.

Per a l'estudi d'associacions entre els diferents tipus de seguiment i control dels pacients per via telemàtica, així com de l'existència de publicacions a revistes científiques derivades de les intervencions educatives fetes als centres i les característiques dels professionals i els centres a què pertanyen, es van calcular els OR (odds ratio) simples corresponents mitjançant models de regressió logística univariants. A fi de valorar l'efecte de l'ajust per a la resta de variables explicatives, es van construir models de regressió logística multivariant, en què es proporcionaven els OR ajustats corresponents. Els models es van construir en dues etapes, que van incorporar al model final diferents grups de variables. En tots els casos es van tenir en compte els possibles efectes d'interacció.

En relació amb l'estudi de l'associació entre el grau de satisfacció laboral i determinades característiques dels professionals i centres de treball, es va construir, en primer lloc, una nova variable, la «satisfacció total», com a suma de les puntuacions de cadascun dels 16 ítems de satisfacció del qüestionari. En segon lloc, es va realitzar una anàlisi de components principals per tal de reduir el nombre de variables de satisfacció (16 items). Aquests components principals van permetre agrupar els ítems en 5 grups, calculant-se 5 variables de satisfacció com a la mitjana de les puntuacions dels ítems corresponents. Seguidament, es van construir models de regressió lineal simple amb cadascuna de les variables explicatives (edat, anys d'experiència en diabetis, formació en diabetis, disponibilitat d'aula per a educació grupal, hores de formació acreditada, tipus d'atenció). Finalment, es van elaborar models de regressió lineal múltiple en els quals es van controlar els possibles efectes d'interacció.

En totes les anàlisis efectuades es va utilitzar el módul d'anàlisi de mostres complexes. 


\subsection{Aspectes ètics}

Aquest projecte es va dur a terme tenint en compte la legislació vigent i acatant les normes étiques de la declaració de Helsinki i de Bona Pràctica Clínica i de Laboratori. L'estudi va ser aprovat pel Comitè Ètic d'Investigació Clínica (CEIC) de l'Hospital Universitari Mútua Terrassa (Annex 4). El tractament, comunicació i cessió de les dades de caràcter personal de tots els subjectes participants s'ajustará a la Llei Orgànica 15/1999, de 13 de decembre, de protecció de dades de caràcter personal, en què es garanteix la confidencialitat pel que fa a la protecció de la legislació vigent del nostre país. La participació en aquesta investigació ha estat voluntària i s'ha sol-licitat als participants el consentiment informat (on s'explicava el propòsit i el procediment de la investigació). Així mateix, ha quedat garantida la petició de consentiments a les direccions oportunes.

Consideracions: I'estudi compta amb el suport de l'Associació Catalana de Diabetis (ACD) (Annex 6). 
100 100 


\section{RESULTATS}

\subsection{Resultats de la primera fase de l'estudi}

Es van seleccionar 15 informants i cap d'ells va denegar la participació en l'estudi. Els informants van ser 8 metges ( 7 endocrinòlegs i 1 metge internista) i 7 infermeres de les quals 6 van participar en el procés d'implementació de l'ETD a Catalunya i una es l'actual responsable del programa «Pacient Expert Catalunya».

Es van identificar 5 metacategories. Les tres primeres corresponen a tres dècades que mostren la història i l'evolució de l'ET a Catalunya i dos més que narren la visió actual de l'ET i la visió de futur de l'ET per part dels professionals implicats.

\subsubsection{La diabetis a Catalunya en la dècada dels setanta}

Tot i que no hi ha dades sobre la prevalença de la diabetis a Catalunya fins a partir de la dècada dels noranta, si que es pot constatar que la diabetis, especialment la diabetis de tipus 2 havia anat incrementant a partir de 1970. La causa principalment descrita era la sobrealimentació degut a l'expansió econòmica, la industrialització i per tant al fàcil accés a tot tipus d'aliments ${ }^{246}$. En aquell moment encara no s'havia produït la reforma de l'Atenció Primària de Salut (APS) i els pacients eren atesos majoritàriament als hospitals o ambulatoris on es resolien bàsicament els problemes aguts. Tal com mostra un estudi sobre dades recollides entre els anys 1976 i 1979, l'educació de les persones amb diabetis era molt deficitària i el nombre d'ingressos hospitalaris per descompensacions era elevat, especialment en els pacients amb diabetis de tipus $1^{247}$. No existien Unitats de Diabetis en els Hospitals, sinó que en general aquesta malaltia era tractada pels serveis d'Endocrinologia o els de Medicina Interna, que destinaven una petita part del seu personal sanitari a cobrir l'àrea assistencial de la diabetis sense tenir l'estructura necessària per desenvolupar adequadament la seva feina ${ }^{248}$.

Encara que no era una percepció majoritària, alguns metges i infermeres eren conscients de les repercussions de la manca d'educació dels pacients:

Els metges ens feien veure que el reingrés era per una manca d'informació i educació. Reingressaven molt sobretot els tipus 1.

\section{Infermera experta en diabetis}




\subsubsection{Primeres activitats relacionades amb la informació/educació de les persones amb diabetis}

\section{a) El paper del metge}

Malgrat que l'ET no estava integrada en el tractament de manera generalitzada en el procés assistencial de les persones amb DM, alguns endocrinòlegs van començar a promoure activitats informatives (conferències i xerrades), activitats per a la integració social, especialment per a nens amb DM, com són les colònies d'estiu.

Alguns d'aquests endocrinòlegs estaven directament implicats en la lluita per la DM que havia iniciat la Cruz Roja Española el 1963, que liderava el Dr. Luis Felipe Pallardo a Madrid des de I'Instituto de Diabetologia, fundat l'any 1970. El diari $A B C$ del dia 6 de febrer del $1972^{249}$ publica una entrevista al Dr. Pallardo, on ell documenta per què es va fundar I'Instituto de Diabetologia. Els paràgrafs següents de l'entrevista mostren quins eren els objectius i les seves activitats:

\section{- ¿Cómo ha surgido la lucha organizada contra la diabetes en España?}

Desde 1965 la OMS viene haciendo recomendaciones en relación con los distintos aspectos de la consideración sanitaria, médico-clínica y terapéutica de la diabetes. En España surgieron en otro tiempo algunos intentos aislados como los del Dr. Blanco Soler i Carrasco Cadenas. Así las cosas, en abril de 1963 la asamblea suprema de la Cruz Roja aprobó mi proyecto de «lucha antidiabética» con extensión a todo el ámbito nacional. A partir de esta decisión, la VII asamblea funda bajo mi dirección el Instituto de Diabetología, con sede actual en Madrid.

\section{- ¿Cuáles son, Dr. Pallardo, los principales objetivos propuestos en esta lucha contra la diabetes?}

Tanto yo como mis colaboradores del Instituto de Diabetología nos hemos planteado tres objetivos: el primero, la detección de la diabetes ignorada; el segundo, una atención médica correcta, suficiente y extensa, y el tercero, la educación del enfermo que haga posible el cumplimiento por su parte de las prescripciones facultativas.

L'Instituto de Diabetología es preocupava de formar metges en diabetologia, així com també infermeres i dietistes, i mantenia relació amb un gran nombre d'entitats estrangeres. Va publicar una revista professional, Diabetología clínica, i un Boletín de la Lucha Antidiabética de la Cruz Roja, d'edició mensual. També realitzava xerrades informatives per a persones amb DM i organitzava colònies d'estiu per a nens amb DM. A més, va promulgar la necessitat del moviment associatiu com un pilar de suport a les persones amb DM, i el 1969 es va crear l'Asociación de Diabéticos de España, amb delegacions a tot al país.

Als anys setanta, alguns professionals a Catalunya es van implicar d'una manera o altra en aquestes activitats que organitzava la Cruz Roja Española, i d'altres que no hi tenien relació 
també van posar un interès especial en l'educació de pacients més enllà de la seva activitat clínica. En podem destacar:

- El Dr. Josep López Batllori, endocrinòleg que llavors era director del Servei de Dietètica de I'Hospital Cruz Roja de Barcelona. Organitzava conferències per a les persones amb DM i els familiars, per tal de sensibilitzar la població en el control de la malaltia. Es considera pioner en el tractament del pacient amb DM, i va incorporar al Servei una educadora dietista, la Sra. Colette Bezzio. Més tard, l'any 1981, quan el Servei de Dietètica es va adherir al d’Endocrinologia i en va ser cap de Servei, el Dr. Jaume Viguera i el Dr. Lluis Vila, també endocrinòlegs, van participar activament en aquestes activitats educatives ${ }^{250}$

- El Dr. Pla Bartina, endocrinòleg de Girona, ens explica en l'entrevista com a principis dels anys setanta, arran d'una conferència que el Dr. Pallardo va fer a l'Acadèmia de Ciències Mèdiques, es va assabentar de les activitats que feia I'Instituto Diabetológico a Madrid. Atès el seu gran interès per la DM, i especialment la DM1, va veure la possibilitat que si s'adheria a la «lucha antidiabética de la Cruz Roja Española» (LACRE) podria fer colònies per a nens amb DM i organitzar millor l'atenció diabetològica a la ciutat de Girona. L'any 1973 va obrir una consulta per a l'atenció a les persones amb DM amb una dietista, la Sra. Carme Sunyol, i aquell mateix any ja van organitzar les primeres colònies d'estiu a Olot ${ }^{251}$.

Vàrem dir, home, si ells fan colònies, per què no en fem nosaltres? Me'n vaig anar a Madrid amb el Dr. Pallardo i vaig sortir amb el títol de jefe de la lucha antidiabética de la Cruz Roja de Gerona. (...) Vàrem començar a Girona a fer colònies per a nens amb diabetis, a España només en feia el Dr. Pallardo a Madrid (a l'Escorial).

Dr. Pla, metge endocrinòleg

Les colònies tenien com a objectiu millorar l'educació diabetològica dels nens amb DM, completar la formació del personal sanitari que més tard es dedicaria a l'atenció de persones amb DM (metges residents que assistien com a monitors), estimular la formació de programes docents i unificar criteris entre els diversos centres on eren atesos els nens que assistien a les colònies ${ }^{252}$.

El 1975, el Dr. Pla es va fer càrrec com a director mèdic del Servicio de Diabetología y Nutrición, creat per un patronat en col·laboració amb la LACRE, i va treballar amb la Sra. Carme Sunyol com a dietista. El Dr. Pla era una persona que ja apostava pel tractament interdisciplinari de la DM i el treball en equip, i també era molt sensible no solament pel que fa als aspectes clínics de la malaltia, sinó també, en particular, als psicosocials i econòmics dels pacients. El dia de la inauguració d'aquest servei, el diari Los sitios de Gerona ${ }^{253}$ va publicar un resum de l'exposició que va fer el Dr. Pla Bartina referent a l'organització i enfocament que es donava a aquest servei:

(...) programando el trabajo en equipo para no caer en la rutina profesional y lograr una más completa y eficaz asistencia del diabético, intentando evitarle desplazamientos inútiles para 
efectuarle exploraciones complementarias y ofreciéndole una asistencia urgente permanente. Se refirió después a que no puede hoy disgregarse la asistencia médica según la capacidad económica del paciente si se quiere mantener la misma calidad en la asistencia. Por este motivo se ha unificado en el Servicio tanto la consulta privada como la de beneficencia. Se han establecido tres tarifas: normal, reducida y benéfica.

Se refirió después a las ventajas del trabajo en equipo, sobre todo en lo referente a que obliga a comentar continuamente las diversas facetas clínicas de cada paciente, siendo así más completa y profunda la visión que llega a tener de su enfermedad...

La filla del Dr. Gusinye, endocrinòleg pediàtric de l'Hospital de la Vall d'Hebró de Barcelona, informa en una conversa telefònica que el seu pare també va tenir la iniciativa d'organitzar colònies per a nens i nenes amb DM a prop de Mataró durant les vacances d'estiu. En aquest cas, el caràcter de voluntarisme i altruisme que aquestes activitats tenien ve determinat pel fet de se'n portaven la família els dies que duraven les colònies.

El Dr. Figuerola va ser el cap de secció de diabetis de l'Hospital Clínic de Barcelona l'any 1975. Inicialment va promocionar l'educació en DM dels professionals de les diferents especialitats un cop va detectar la necessitat de transmetre'ls eines per ajustar les pautes d'insulina dels pacients ingressats. En aquestes sessions de formació es van incorporar les infermeres dels diferents serveis, fet bastant inèdit en aquella època:

Una primera fase educativa va ser la formació dels metges, és a dir, metges de qualsevol especialitat, qualsevol servei quirúrgic, els reuníem el dissabte al matí en una taula, metges i infermeres. Va ser la primera incorporació de les infermeres en el procés i això va cridar molt l'atenció. Això era nou llavors, que la infermera comencés a tenir capacitat decisòria amb les pautes d'insulina no era gens estès.

\section{Dr. Figuerola, metge endocrinòleg}

\section{b) El paper de la infermera}

Els resultats de la recerca històrica documental i les entrevistes als professionals que a Catalunya van fomentar aquest punt d'inflexió en el tractament de la DM mostren que en la dècada dels setanta la situació era la següent:

- No existia la figura d'infermera educadora de diabetis. El paper de les infermeres en el camp de l'educació de pacients amb DM, fora de l'àmbit hospitalari, era poc rellevant. En general, el coneixement que tenien de la DM era sobre el tractament farmacològic o insulina, l'alimentació i no gaire cosa més. Les que treballaven en àrees d'hospitalització de DM o en serveis d'Endocrinologia estaven més preparades, però tenien un paper educatiu minoritari, de col·laboració amb el metge, fent tasques molt bàsiques com ara ensenyar la tècnica d'administració de la insulina, o les pautes d'alimentació o d'autoanàlisi, bàsicament en 
orina, durant l'hospitalització del malalt diabètic. Sovint era el metge l'encarregat de donar tots els coneixements teòrics sobre la malaltia. Malgrat això, hi havia alguns metges que havien conegut altres experiències fora del país que insistien en la importància del paper dels professionals d'infermeria:

El Dr. Pou havia sentit que als EUA hi havia infermeria que ho estava fent i ens ho transmetia, ens deia: «A fora d’Espanya la diabetis és un tema que porta infermeria», i ens ho anava explicant una miqueta, però hi havia molt de voluntarietat, inclús amb el Dr. Lloveras fèiem les coses bàsiques. (...) El Dr. Leiva, que venia d’Estats Units, de la Clínica Joslin, ens deia: «Existeix una figura que és l'educadora de diabetis, que té una tasca molt important i que fa una tasca molt preventiva a l'hora de l'ingrés del pacient».

Infermera experta en diabetis

- Hi havia el convenciment que les persones amb DM, sobretot amb DM1, havien d'estar informades sobre la malaltia, el tractament i les complicacions. Més que educar, el que es feia era informar, i això era patrimoni només d'alguns professionals. Moltes vegades aquestes sessions informatives es realitzaven en els mateixos hospitals on treballaven els professionals implicats, o en centres externs com ara casals de cultura; en aquest cas moltes vegades es feien en col·laboració amb l'Asociación de Diabéticos de España. Aquestes activitats eren minoritàries, bàsicament hi participaven els metges 0 , de vegades, alguna dietista, i la seva difusió es feia a través d'anuncis al diari ${ }^{254}$.

- S'utilitzaven els models d'ensenyament amb mètodes tradicionals, és a dir, unidireccionals, com xerrades o conferències amb un programa establert que podia durar un mes, amb un total de 4-8 sessions repartides entre un o dos dies a la setmana (Annex 7).

- Hi havia un gran interès per la integració social de les persones amb DM. Els canvis i moviments socials també es reflectien en el camp de la salut, i especialment la DM encara era un estigma social important. De fet, l'any 1971 el Dia Mundial de la Salut va estar dedicat a la DM amb el lema «Vida normal para los diabéticos» ${ }^{255}$.

\subsubsection{Influències dels canvis polítics i socials a la segona meitat de la dècada dels setanta}

Entre mitjans i finals dels anys setanta, de mica en mica a Catalunya es va crear una consciència col·lectiva sobre la necessitat d'una salut pública en el sentit de promoció de la salut i prevenció de la malaltia. Era l'època postfranquista immediata, l'època de la democràcia, de gran expansió, on els canvis polítics i socials trencaven els esquemes i les normes i es buscaven noves maneres de fer. Es parlava d'un canvi de paradigma en la medicina envers una forma més holística de tractar les malalties, sobretot les malalties cròniques, entre les quals la DM, i se'n defensava un tractament multidisciplinari en unitats especialitzades. Amb la restauració de la Generalitat, 
I'any 1977, la millora del sistema sanitari català va ser un dels primers objectius del Govern, i el primer pas va ser l'elaboració, I'any 1979, del Mapa Sanitari de Catalunya, un complet estudi de la situació, amb anàlisis i propostes concretes per a cada sector i àrea territorial, sota la direcció del conseller Dr. Ramón Espasa. Aquest canvi queda reflectit en moltes afirmacions dels professionals entrevistats:

Aquí estàvem a l'època de la transició, de la democràcia que començava, d'obrir nous horitzons, de canviar paradigmes.

\section{Metge endocrinòleg}

A l'any 78-79, estàvem ja en l'època democràtica, es començava a parlar del mapa sanitari de Catalunya, en aquell moment el conseller era el Dr. Espasa. Es parlava de la possibilitat de fer unitats de diabetis, endocrinologia i nutrició. (...) Vaig començar a treballar amb el model del Dr. Pla de Girona, que llavors també estava lluitant per les unitats de diabetis.

\section{Metge endocrinòleg}

En aquell moment es va donar, el moviment social, l'edat, uns líders que s’ho creien, l'entusiasme i una gran motivació personal.

\section{Infermera experta en diabetis}

Diversos serveis d'Endocrinologia d'hospitals de Catalunya van començar a treballar en aquesta direcció i es van començar a formar equips amb metges i infermeres que feien educació, però a la vegada amb molta necessitat de formació. Una infermera resumeix amb aquestes paraules el sentiment de canvi que es vivia llavors:

\footnotetext{
A tot arreu es respirava un ànim i una empenta d'«ara sí que podré», «ara sí que anirem endavant» en els joves professionals, amb mestres que d'alguna manera marcaven una idea de la medicina molt més holística, una idea contraposada a la medicina basada en l'hospital i basada en les especialitzacions; es buscava potenciar els hospitals comarcals i potenciar la reforma de l'assistència primària. La declaració d'Alma Ata encara era molt tendra, però hi havia la idea d'aproximar la sanitat al ciutadà, de fer equips més humanitzats i d'integrar tres aspectes: I'aspecte de compromís social, l'aspecte de medicina basada en l'evidència científica, la idea que el Clínic havia de fer recerca i que la recerca clínica era tan important com la recerca bàsica.
}

\section{Infermera experta en diabetis}




\subsubsection{Dècada dels vuitanta. Procés d'implementació de l'ueducació diabetològica» a Catalunya}

A finals dels anys setanta i al llarg vuitanta es va produir una sèrie d'esdeveniments influenciats pels canvis polítics i socials, i a l'hora per una sèrie d'evidències científiques en el camp de la medicina, així com alguns avenços tecnològics que van demostrar la importància de l'educació en el tractament de la DM. Per aquestes raons, el valor que s'anava donant a l'educació diabetològica (que és com s'anomenava en aquell moment l'ET) no té precedents en el moment actual.

El procés d'implementació de l'educació diabetològica a Catalunya a la dècada dels vuitanta va comportar la creació de les primeres unitats de DM de caire multidisciplinari, on el concepte d'equip era important i la infermera ja tenia un paper rellevant en l'educació dels pacients.

\subsubsection{Les primeres Unitats de Diabetis i el paper de la infermera}

A Catalunya, la primera Unitat de Diabetis es va crear a l'Hospital de la Santa Creu i Sant Pau, quan el Dr. Leiva en va ser el cap del Servei d’Endocrinologia i Nutrició, el 1981. Les motivacions que el van impulsar a crear la Unitat de Diabetis, segons explica a l'entrevista, van provenir de les seves experiències prèvies, quan va fer la residència de medicina a Madrid amb el Dr. Pallardo, i més tard quan es va anar a la Clínica Joslin de Boston, als EUA.

Hice la residencia en Madrid. El Dr. Pallardo llevaba el instituto Diabetológico de la Cruz Roja y hacía cursos para diabéticos. Yo estuve con él, hacía educación pero no como la entendemos ahora, aquello eran conferencias. Iba por los pueblos, yo iba por ahí con él y no solamente en las ciudades, sino por pueblos pequeños. Así fue como empecé en esto. Después me fui a América y estuve en la Joslin. Allí había un interés extraordinario, no se improvisaba nada y no había caso que no se tratara conjuntamente con todo el equipo. Estuve con Priscila White, pionera en el tratamiento de la diabetes durante el embarazo y la diabetes tipo 1; atendía a niños con diabetes e instauró en el periodo de vacaciones los campamentos para niños con diabetes y yo tuve la oportunidad de participar en ellos.

\section{Dr. Leiva. Metge endocrinòleg}

Aquesta primera Unitat de Diabetis a l'Hospital de la Santa Creu i Sant Pau des del començament va ser estructurada, amb infermeres únicament dedicades a l'educació de pacients, un podòleg i un psicòleg. Destaquem entre les infermeres la Sra. Justa Úbeda i la Sra. Pilar Villabona, així com la Sra. Emilia Belda. Això era una situació excepcional, com es reflecteix en els comentaris d'infermeres d'altres hospitals: 
En el Hospital de Sant Pablo sí que empezaron y consiguieron una unidad estructurada e interdisciplinar que era la admiración, al menos la mía, porque eran hospitales similares y ellos tenían un equipo formado por podólogo, una psicóloga de soporte, enfermeras, médicos. Es lo que se defendía desde un punto de vista teórico, unidades de diabetes interdisciplinares en un hospital. Ellos lo consiguieron muy pronto.

Dra. en Infermeria. Infermera experta en diabetis

El 1981 s'incorpora a la Unitat de Diabetis de l'Hospital Clínic de Barcelona la Dra. Pilar Isla com a infermera supervisora del Servei d'Endocrinologia i Diabetis, que juntament amb el Dr. Figuerola es va dedicar a donar classes pactant uns continguts que impartirien als pacients ingressats, distribuïts en diferents sessions durant la setmana. A partir de llavors es comença a gestar el que seria un programa educatiu estructurat amb diverses sessions i amb una metodologia clàssica, unidireccional. La Dra. Pilar Isla refereix en la seva entrevista que hi va haver una gran implicació de les infermeres assistencials de la Unitat de Diabetis dels diferents torns. Realment, això es va poder fer perquè hi havia una bona relació de treball en equip.

\subsubsection{Creació del Consell Assessor sobre la Diabetis a Catalunya}

El Consell Assessor sobre la Diabetis a Catalunya es va crear l'any 1983 (Ordre de 18 de març de $1983)^{256}$ com a òrgan consultiu del Departament de Sanitat i Seguretat Social per tal d'assessorar i promoure actuacions en favor de les persones amb DM. Les seves funcions, entre d'altres, eren informar i assessorar sobre les línies prioritàries en matèria de prevenció i profilaxi, educació sanitària, formació, informació i sensibilització sobre la DM. La seva composició era, segons recull l'article III de l'esmentada ordre: $a$ ) un president, $b$ ) un vicepresident (escollit entre les persones esmentades als punts $c$ i $d$ ), $c$ ) quatre persones escollides entre les proposades per I'Associació Catalana de Diabetis en representació de les associacions de diabètics d'àmbit català, $d$ ) quatre persones escollides entre les proposades per la Societat Catalana de Diabètics, de l'Acadèmia de Ciències Mèdiques de Catalunya i Balears, i $e$ ) un representant de la Secretaria General i les Direccions Generals de Promoció de la Salut, d'Assistència Sanitària i de Serveis Socials, així com un representant de l'Institut d'Estudis de la Salut per tenir cura de les funcions de secretaria.

El Consell Assessor sobre la Diabetis a Catalunya va ser presidit en el seu inici pel Dr. Gonçal Lloveras, que havia sigut sotsdirector del Servei d'Endocrinologia i Nutrició de l'Hospital de Sant Pau. El Consell Assessor va tenir un pes molt important en la formació de professionals en DM i educació, des de la seva creació fins i durant gran part de la dècada dels noranta. També va ser el principal suport polític que van tenir els professionals per a la implementació de l'educació diabetològica a Catalunya. 


\subsubsection{Barreres per al desenvolupament de l'ET}

Les primeres dificultats a l'hora introduir l'educació de manera sistemàtica en el marc del tractament de la DM, expressades pels professionals que començaven a desenvolupar aquesta tasca educativa, van ser:

\section{a) Controvèrsies sobre la necessitat de l'educació}

Com tots els canvis dins de grans estructures on intervé un gran nombre de professionals, no tothom té les mateixes idees, o bé aquestes idees no entren en les persones amb el mateix grau d'intensitat. Això és el que va succeir quan es va voler introduir l'educació com a part integral del tractament a diversos centres. No tots els professionals, ni tan sols dins d'un mateix equip, estaven d'acord que el pacient havia de ser educat. Les discrepàncies sobre l'actitud autoritària que el pacient havia de complir amb les ordres del metge, la creença que educar el pacient era una complicació per als professionals i el fet que el pacient no havia de saber com un metge, eren molt presents:

Había personas que estaban muy a favor y otras que no le encontraban ningún sentido y que incluso, si les pedías la opinión, estaban en contra de la educación y entonces costaba mucho; lo de educar al enfermo había quien lo consideraba fundamental y había quien consideraba que al enfermo le tenías que decir lo que tenía que hacer, él no tenía que saber más que lo que tú le decías que tenía que hacer, porque esto era una complicación para todos.

Dra. en Infermeria. Infermera experta en diabetis

Haig de reconèixer que en molts llocs això va ser una mica de fracàs perquè no tots els endocrinòlegs tenien consciència de com d’important era l'educació diabetològica.

\section{Metge endocrinòleg}

Aquesta realitat també s'expressa en l'article publicat pel Dr. Figuerola el 1983, en el qual afirma:

No todo el personal médico y sanitario que trata a diabéticos está suficientemente convencido de que es necesario proporcionar información a los pacientes sobre su enfermedad, y a menudo piensa que de este modo se aumentan los niveles de ansiedad del enfermo. Este punto de vista corresponde a una actitud paternalista que, a mi juicio, carece de sentido en la actualidad ${ }^{248}$.

Dr. Figuerola. Metge endocrinòleg 


\title{
b) Controvèrsies sobre el paper de la infermera en l'educació de pacients
}

En tant que alguns endocrinòlegs potenciaven el paper de la infermera, altres el desacreditaven. En aquell moment el treball de la infermera es fonamentava en tasques delegades del metge i l'acte de fer petites modificacions del tractament era vist per molts metges com una intromissió en l'acte mèdic, argumentant, en alguns casos, una falta de preparació de la infermera:

\begin{abstract}
En aquella época, cuando empezaban las primeras unidades de educación con enfermeras, escuché muchas opiniones de médicos que decían que la enfermera no estaba preparada para tener este papel y se veía como un posible riesgo... De alguna manera no se veía necesario dar tanto protagonismo a la enfermera o que la enfermera pudiera entrar en la dosis de insulina u opinar en el tratamiento. Pero para enfermería era un tema muy novedoso, pero sobre todo, muy engrescador, porque daba protagonismo a la enfermera.
\end{abstract}

Dra. en Infermeria. Infermera experta en diabetis

Hi havia gent que no havia treballat a gust amb infermeria, per problemes d'autoritat, perquè canviaven pautes.

Metge endocrinòleg

Había colegas que pensaron que si la enfermera realizaba este trabajo era una intromisión, era una invasión a su propia área de trabajo. Pero no es cierto, la formación en diabetes de una enfermera es una especialidad y hay que luchar por ello.

\section{Metge endocrinòleg}

En contraposició, hi havia qui creia que ensenyar els pacients no era feina del metge. Respecte de les infermeres passava el mateix, ja que algunes no creien en la necessitat d'educar el pacient, d'altres ho veien com una forma de cura integral i com una manera de millorar les complicacions i la qualitat de vida:

A mí me decían otros compañeros médicos: «¿Tú por qué haces esto? Esto es de enfermeras»; yo decía: «¿Cómo que de enfermeras? Es de todos, esto no obedece a rangos».

Metge internista

Alguna persona deia que quan els pacients saben es tornen més «preguntons» i més neuròtics. La majoria no era això, però si era dir...: «A mi no en facis ara fer això... Això que ho faci la infermera....».

\section{Metge endocrinòleg}




\section{c) Falta d'infraestructura}

La educació de pacients no es preveia dins de la infraestructura sanitària. Als centres sanitaris no existien espais adequats per fer educació, ni els mínims recursos materials. Van ser els mateixos professionals els que buscaven l'espai més adient o més accessible per començar a desenvolupar els seus programes educatius:

\footnotetext{
Fèiem l'educació del pacient mentre estava ingressat. Ens endúiem els pacients a una saleta per assegurar que quan se n'anaven d'alta, el que era bàsic ho tinguessin fet. Desprès ja va passar que hi va haver infermeria a dispensari i vam muntar els cursos a sota d'una manera més acadèmica i més organitzada.

Infermera experta en diabetis
}

Utilizaba para atender a los pacientes una consulta que habían utilizado los traumatólogos por la mañana y tenía que limpiarla.

\section{Metge internista}

\section{d) Falta de referents i formació específica en educació de pacients}

A principis dels anys vuitanta a Catalunya no hi havia professionals experts en educació als quals poder utilitzar com a referents, i tampoc hi havia formació específica en DM i educació per a professionals, tot i que des de finals dels anys setanta molts professionals de la salut havien apostat per l'educació en DM. Tot això, entre altres aspectes, ho posa de manifest el Grup de Treball d’Educació Sanitària Aplicada a la Diabetis que es va constituir per elaborar una ponència durant les «Jornades sobre programes comunitaris en diabetis» (Annex 8) que es van celebrar el 1989, en la qual diuen explícitament:

No hi ha models reproduïbles, però sí que hi ha mètode de treball (cal disciplina i professionalitat).

Grup de Treball d'Educació Sanitària Aplicada a la Diabetis

Els centres pioners gairebé van començar alhora i les infermeres de les unitats de diabetis que havien començat a fer educació de pacients tenien una gran necessitat d'interrelació per tal d'incrementar el seu coneixement a través de l'intercanvi d'experiències amb companyes d'altres hospitals o recerques bibliogràfiques, i també amb la il·lusió d'obrir un nou camp dins la infermeria. 
La primera gran dificultat va ser el primer dia que vaig entrar al despatx i el primer que vaig dir va ser: «l ara jo què faig?». No en tenia ni idea (estiu de 1980). Llavors vaig dir: «Si tu no estàs capacitat per innovar, copia. I això vol dir conèixer què fan els altres, i el que fan els altres que t'agradi, doncs intenta adaptar-ho si no ets capaç d'inventar una cosa millor». Vaig començar a veure què feien a Sant Pau, llavors a Sant Pau hi havia el Dr. Leiva i el Dr. Lloveras.

\section{Infermera experta en diabetis}

Els primers referents sobre el que ara coneixem com educació terapèutica van venir de la mà del Dr. Figuerola. Ell va tenir l'oportunitat, al 1980, de conèixer l'experiència d'un dels grups pioners a Europa sobre el tractament i l'educació terapèutica en DM. Va assistir, juntament amb la dietista del Servei, la Sra. Rita Rigolfas, a un curs impartit pel professor Jean Philippe Assal, que en aquell moment era president del Diabetes Education Study Group (DESG) i director de la Divisió d'Educació Terapèutica de l'Hospital Cantonal de Ginebra. Les classes amb el professor Assal i el seu colllaborador i pedagog, el prof. Guido Rufino, van ser un descobriment del que era la didàctica en educació de pacients.

Va arribar una invitació de l'Assal, ja que algú li va donar el meu nom. Vam fer un procés de formació amb ell i vam anar amb la Rita Rigolfas, la dietista, i vam caure del cavall...Vam tenir la sensació que això és un altre món, una altra història, un abordatge diferent i vaig tornar a l'hospital amb molta empenta.

\section{Dr. Figuerola. Metge endocrinòleg}

El 1982, el Dr. Figuerola va organitzar una trobada amb un grup d'endocrinòlegs d'arreu de Catalunya que ja tenien certa activitat en la formació de pacients, per tal de donar a conèixer el model educatiu dels professors Assal i Rufino, i crear una xarxa de professionals. Aquesta trobada va generar un gran interès, motivació i il-lusió per crear nous projectes educatius dins del marc d'atenció a la DM.

En Guido Rufino ens va fer veure que no sabíem res del que era la docència, no en diabetis, sinó la docència, que la gent entengués el que els hi volíem fer entendre. Això va ser una revolució i llavors vàrem demanar aprofundir en això.

\section{Dr. Figuerola. Metge endocrinòleg}

Amb en Guido vaig entendre que per fer la feina que se'm demanava havia de saber molt de diabetis i molt d'educació. De diabetis en podria aprendre de qualsevol llibre.

Infermera experta en diabetis 
Els professionals que creien en la importància de l'educació de les persones amb DM i volien treballar d'una manera diferent eren molt conscients de la manca de formació específica quan s'iniciaven:

En el moment que em vaig haver de dedicar a la diabetis, et vas adonant que amb els coneixements de la facultat i l'abordatge biomèdic clàssic no es va enlloc, és un fracàs continu $i$, per tant, vas descobrint que és absolutament necessari millorar la teva capacitat de persuasió, seducció, educació...

Metge endocrinòleg

Cuando llegué allí vi que me tenía que formar, me empecé a comprar libros. Fue un sitio donde tenías que aprender rápido, teníamos una UCl metabólica donde ingresaban continuamente enfermos por complicaciones agudas graves de la diabetes, había un páncreas artificial... Los conocimientos básicos que tenías más los libros y las preguntas que hacías hizo que te fueras poniendo al día. Pero lo que no tenías era formación pedagógica, porque ni el el grado ni el posgrado nunca te habían enseñado.

Dra. en Infermeria. Infermera experta en diabetis

\subsubsection{Els cursos de formació en diabetis del Institut d'Estudis de la Salut. La formació interdisciplinària en diabetis}

Justament per aquesta falta de formació i de referents dels quals parlàvem, I'IES, que feia cursos de tota mena, va organitzar-ne uns de DM per a professionals, anomenat Curs Bàsic de Diabetis, en el qual participaren com a professors metges endocrinòlegs, infermeres i dietistes de centres on ja estaven treballant en l'educació de les persones amb DM. Aquest curs el van realitzar majoritàriament professionals de l'AP. Els continguts es van dividir en tres mòduls, una presentació del curs i l'avaluació de coneixements el primer dia. L'últim dia, amb la cloenda, es realitzava una exposició d'experiències i un cas pràctic amb discussió de grup i posada en comú. Tot i que en el primer mòdul es parlava d'educació sanitària, la resta eren continguts bàsicament clínics relacionats amb la DM i, malgrat l'interès del professorat, hi havia una manca de formació pedagògica de la qual eren molt conscients:

El IES empezó a crear unos estudios de formación que eran una formación clínica en diabetes, no era una formación en educación. Nos empezaron a llamar como profesores a las personas que estábamos en los sitios un poco relevantes, en las unidades de diabetes, pero no tenías metodología pedagógica, contabas lo que hacías pero sin una estructura bien hecha.

Dra. en Infermeria. Infermera experta en diabetis 
(...) podíem tenir conceptes a nivell de diabetis, però no teníem formació en el que era la pedagogia, la didàctica, entendre les vivències del pacient.

\section{Metge endocrinòleg}

Arran d'aquestes experiències (el descobriment del Dr. Assal i el prof. Rufino i la participació com a professors en els cursos de l'IES), el professorat d'aquests cursos s'adona que realment per poder ensenyar, tant els altres professionals com els pacients, cal una formació específica, sobretot basada en metodologia educativa i en pedagogia, és a dir, hi ha una constatació que els professionals, tant metges com infermeres, tenen la necessitat d'aprendre a ensenyar. El Dr. Figuerola expressa d'aquesta manera en un article publicat el 1983 la manca de recursos que hi havia en formació quant a pedagogia i metodologia educatives:

Los incipientes equipos de enseñanza a diabéticos que actualmente están funcionando carecen de una preparación pedagógica adecuada y no disponen de material suficiente (vídeo, publicaciones, diapositivas), lo cual da lugar a una rentabilidad mucho menor de lo que podría obtenerse ${ }^{246}$.

L'IES decideix fer front a aquesta demanda de formació específica en metodologia de l'educació i va començar a organitzar, l'any 1984, amb el suport del Consell Assessor sobre la Diabetis, diversos cursos de formació en DM i educació sanitària de caràcter interdisciplinari (metges endocrinòlegs, infermeres i dietistes, així com algunes persones que treballaven a la indústria farmacèutica o que venien de les associacions de persones amb DM).

Aquests cursos van ser, en primer lloc, el Curs d'Educadors en Diabetis (durava un mes, amb 4 hores totes les tardes, i els continguts es van dividir en quatre mòduls), i el Curs de Formació de Professorat en Educació Diabetològica, que va durar un any i va estar organitzat bàsicament pel Consell Assessor sobre la Diabetis a Catalunya. L'objectiu d'aquest curs era dotar els professionals de la metodologia pedagògica imprescindible per millorar la seva qualitat docent. El coordinador dels cursos va ser el Dr. Ignasi de Juan Creix, metge format a l'escola d'Educació Sanitària de la Universitat de Perugia, centre pioner a Europa.

En el Curs d'Educadors en Diabetis es va potenciar molt la figura de la infermera. Les que treballaven a I'Hospital Clínic, com la Sra. Pilar Isla o la Isabel Bailo, o a l'Hospital de Sant Pau, com la Sra. Justa Úbeda o la Pilar Villabona, centres on començaven a tenir força experiència en educació diabetològica, van participar com a professores o coordinadores d'aquests cursos de formació, juntament amb el Dr. Ignasi de Joan Creix.

El Curs de Formació de Professorat en Educació Diabetològica es pot dir que ha estat el curs més important de formació en educació sanitària aplicada a la DM que s'ha fet fins al moment actual. La proposta formativa es va presentar a la I Conferència Europea d'Educació Sanitària, que es va celebrar a Madrid al març de 1987 (Annex 9). 
L'Ignasi Juan Creix, amb la metodologia de treball i les tècniques de treball en grup amb què es van plantejar aquests cursos (dinàmiques grupals, panels de discussió, pluja d'idees, sociodrames, discussions de grup, i altres tècniques, com el Philips 66), va capgirar el concepte que la majoria tenia del que era educar, provocant sensacions de tota mena entre els alumnes: per uns resultava una pèrdua de temps, i per altres allò era ridícul, eren jocs de nens, «com era possible que uns professionals tan seriosos es posessin a fer sociodrames, envoltats d'un grup de persones que els miraven i desprès els criticaven?». Però a mesura que anaven passant els dies la visió canviava, era un descobriment absolutament fascinant sobre com la comunicació podia alterar o afavorir la relació entre professional i pacient, de veure la persona com un "tot», d'assimilar conceptes com equip interdisciplinari o horitzontalitat, entre molts d'altres, que potser mai aquests professionals s'havien arribat a plantejar:

Nosotros pensábamos que era un curso para aprender diabetes y luego no fue nada de diabetes, sino que era un curso para aprender metodología de la educación sanitaria, que entonces se llamaba sanitaria, no terapéutica, y fue un revulsivo, ya que nos analizábamos nosotros mismos, no eran clases que te dijeran lo que tenías que hacer, sino que era un análisis, una crítica de lo que estábamos haciendo, con una metodología muy participativa, activa, practica, ya que tanto hacíamos role playings o análisis de actitudes como nos obligaban a preparar una clase con una metodología activa y hacerla. Fue el primer curso que era totalmente interdisciplinar y en el que coincidían como alumnos jefes de servicio y enfermeras educadoras.

Dra. en Infermeria. Infermera experta en diabetis

(...) quan va aparèixer l'Ignasi Juan Creix, en aquella època jo era molt quadrada, m'agradava molt la part d'educació i tal però era molt quadrada. Em recordo que el segon dia jo me’n volia anar cap a casa perquè tenia molta feina, tenia molts malalts per visitar i tenia la sensació que estava perdent el temps, però al cap de sis mesos m'havia canviat la vida, la manera de mirar moltes coses. Això va ser un dels puntals que ens va esperonar a tots, veure l'educació no com només donar informació. Va canviar el concepte d'educació completament.

\section{Metge endocrinòleg}

L'Ignasi ens va remoure molt, perquè nosaltres en el fons el que buscàvem era aprendre a ensenyar millor, és a dir, hem d'ensenyar els pacients.

\section{Metge endocrinòleg}

Una de les característiques cabdals i alhora més novadora que van aportar els cursos de l'IES va ser potenciar el treball en equip. Existia des de la mateixa organització dels cursos la convicció al voltant de la importància del tractament interdisciplinari de la DM i la necessitat que tots els actors implicats en la malaltia treballessin en equip. Un equip no es considerava com a integrat 
pel metge i la infermera, sinó que anava més enllà i els membres de les direccions dels centres o àrees sanitàries, així com tots aquells professionals amb els quals els pacients tenen relació, també formàvem part de l'equip:

L'Ignasi, que venia de l'Escola de Perugia, era del parer que tothom havia de fer aquest procés de l'educació sanitària aplicada a la diabetis, que deia ell. Ell considerava que això era tan important que ho havien de fer els gerents dels hospitals, ho havia de fer tothom... i ell va intentar aplicar aquesta metodologia.

\section{Metge endocrinòleg}

Als anys vuitanta s'estava produint la reforma de l'Assistència Primària, que va finalitzar l'any 1992. Era crucial dotar els professionals de formació, i aquests cursos de DM i d'educació sanitària aplicada a la DM complien aquesta funció. La gran quantitat de professionals que van realitzar els cursos de l'IES, especialment el curs de Formació de Professorat en Educació Diabetològica, va permetre la creació d'equips referents a les quatre províncies catalanes, en què van destacar els següents: a Barcelona, els equips de l'Hospital de Sant Pau, l'Hospital Clínic, I'Hospital de Mataró, I'Hospital de Granollers, I'Hospital Mútua Terrassa o el del CAP II Sant Félix de Sabadell; a Lleida, el del CAP Prat de la Riba; a Tarragona, el de I'Hospital Joan XXIII, i a Girona, els equips de les àrees bàsiques de la mateixa ciutat $\mathrm{i}$ també de Figueres.

De les coses que jo em sento més orgullosa d'aquella època va ser la part del que vam engegar d'educació als malalts i la part d'educació a metges i infermeres. Va ser la primera vegada que metges i infermeres van anar a un curs junts per veure com s'ha de treballar en equip. El bo de treballar conjuntament metge i infermera és que l'un s'alimentava de l'altre.

\section{Metge endocrinòleg}

Un cop es van consolidar els equips referents, es va organitzar el curs de Perfeccionament en Educació Diabetològica, coordinat pel Dr. Ignasi de Joan Creix i la Sra. Pilar Isla. Aquests cursos, de 60 hores, es van fer a l'Hospital Clínic de Barcelona, i van ser gestionats per l'IES amb la colllaboració del Consell Assessor sobre la Diabetis a Catalunya. Es va convidar a fer el curs a equips professionals de metge i infermera d'hospitals i CAP de les diferents àrees sanitàries de Catalunya. Se'n van fer tres edicions, i això donava lloc a la creació d'equips a tots els hospitals i centres d'atenció ambulatòria especialitzada (CAP II). Es pot constatar pels relats de les entrevistes que la formació en educació va tenir un gran interès per a la majoria de professionals, però encara hi havia metges que pensaven que educar no formava part de la seva feina.

El primer curs vaig demanar a les àrees que deixessin venir a un equip, un metge i una infermera per poder fer formació. El curs d'educació sanitària era per a professionals... tots barrejats, res de fer separacions.

\section{Metge endocrinòleg}


Quan es va començar a proposar els cursos de formació, perquè es tractava que la gent no podia fer improvisadament educació terapèutica, recordo companys meus que em deien: «Jo si haig de fer aquest procés de formació per aprendre a ensenyar, doncs no, no el faré». Hi havia les dues vessants.

\section{Metge endocrinòleg}

Com que l'objectiu d'aquest curs era formar altres formadors, un cop finalitzades les tres edicions es va descentralitzar a les diferents àrees sanitàries, seguint el mateix model interdisciplinari i metodologia participativa, impartits i coordinats pels exalumnes dels cursos de I'IES. Aquesta formació va permetre dur a terme a les àrees sanitàries «programes d'atenció al diabètic» a fi de millorar la coordinació entre l'AP i l'AE, millorar l'accessibilitat dels pacients als recursos materials (tires reactives, xeringues o agulles per a l'administració de la insulina), així com també millorar la capacitat diagnòstica i de tractament de les persones amb DM, tot seguint les directrius de la Declaració de Saint Vincent.

El 1986 es redueix l'oferta de formació per part de I'IES, que també va optar per descentralitzar el Curs Bàsic de Diabetis, i va passar a oferir-lo als hospitals i CAP amb el suport del Consell i el diploma de I'IES, argumentant el següent:

\footnotetext{
Atès que ja hi ha un gran nombre de persones de Barcelona que han fet el curs, creiem que cal procedir a la seva descentralització, de manera que us farem arribar un llistat amb els diferents centres de tot Catalunya on es facin aquests cursos.
}

Proposta de les activitats del Consell Assessor sobre la Diabetis a Catalunya per al curs 1986-87

\subsubsection{Elements que van facilitar la implantació de l’ET a Catalunya}

En aquest apartat s'intentarà descriure com ha sigut l'evolució de la implantació de l'ET a través de diferents apartats corresponents a cadascun dels aspectes més rellevants que van influir en aquesta evolució:

\section{a) La formació dels professionals}

L'element principal que va facilitar la implantació de l'ET arreu de Catalunya va ser la formació dels professionals a través dels cursos de I'IES, dels quals s'ha parlat a l'apartat anterior. Un aspecte que va contribuir a la formació dels professionals i que, a més, va potenciar la sensibilitat per l'educació van ser les conferències de figures rellevants de la pedagogia, com la Sra. Anne Lacroix i el Dr. Mauriccio Mori, de la Unitat de Diabetis de I'Hospital Cantonal de Ginebra, o el prof. Berguer, diabetòleg de Düseldorf (Alemanya). Aquesta formació va permetre als professionals de la infermeria: 
- El lideratge de la infermera en el desenvolupament de programes d'educació, la seva aplicació i avaluació, motiu de presentacions a les reunions i congressos de les societats científiques.

- La recerca infermera en el àmbit de l'ET, liderant projectes d'investigació i publicacions a revistes científiques.

- La participació de les infermeres com a membres actives de les societats científiques en grups de treball multidisciplinaris.

Pel que fa a les aportacions en el camp de la formació en ET a escala europea, cal destacar que a Catalunya hi ha dos grans referents a partir dels anys vuitanta:

1. La anomenada Escola Suïssa del Dr. J. Ph. Assal i el prof. Guido Rufino, de l’Hospital Cantonal de Ginebra. Va ser una influència molt important per a l'aprenentatge de metodologia i tècniques educatives que encara perdura en el moment actual. Els cursos d'estiu que s'organitzaven cada any a Grimentz van marcar una manera de fer a tot el col-lectiu implicat en l’ET els anys noranta.

Algo importante que caracteriza al grupo de Cataluña es su influencia por Ginebra, por Grimentz. Los cursos de verano que se realizan en Grimentz pienso que han dejado huella y también han marcado un modo de hacer.

Infermera experta en diabetis

2. El Diabetes Education Study Group (DESG), presidit pel Dr. J. Ph. Assal des del 1979 fins al 1985, va desenvolupar una sèrie d'activitats i material d'un gran valor educatiu, els quals sempre han estat un marc de referència per a l'ET, com són les teaching letters, documents pràctics d'ajuda al professional per a una educació més eficaç.

L'esperit del DESG era que hi hagués una manera per transmetre els coneixements o per involucrar la gent perquè fos realment més participativa i que pogués tenir autonomia.

Metge endocrinòleg

\section{b) L’evidència científica i els avenços tecnològics}

La majoria de professionals entrevistats està d'acord que els estudis que havia publicat L. Miller als EUA a principis dels anys setanta sobre l'eficàcia de l'educació dels pacients, i d'altres publicacions de diversos grups europeus als anys vuitanta, van potenciar la importància de l'educació en el tractament de la DM i el paper de la infermera, dins de les Unitats d'Endocrinologia i Nutrició dels hospitals o dels centres ambulatoris d'especialitats. Més tard, l'any 1989, el 
objectius que va establir la Declaració de Saint Vincent van reforçar molt el desenvolupament de programes d'ET liderats en aquell moment, en la majoria de centres, per infermeres que s'havien format pocs anys enrere en els cursos organitzats per l'IES.

Después la publicación de artículos relevantes, como el de Miller en EUA, el de Assal sobre la prevención de amputaciones en Suiza, y la concienciación a nivel político por la Declaración de Saint Vincent, hubo algunos médicos diabetólogos que, en aquel momento, tenían cargos de gestión y les interesó mucho este problema; en mi hospital, por ejemplo, fue el Dr. Figuerola.

Doctora en Infermeria. Infermera experta en diabetis

La motivación fundamental surge de la necesidad de incorporar la educación en el tratamiento porque se evidencia que forma parte fundamental del tratamiento.

Infermera experta en diabetis

El corrent que va venir de Suïssa amb l'Assal, etc. va fer que aquí es comencés a plantejar que dins de la diabetis l'educació formava part del tractament.

\section{Metge endocrinòleg}

L'increment de la utilització de tires reactives per al control de la glucosa en sang va donar un impuls a la tasca educativa, a la vegada que feia possible un ajust més acurat de les teràpies per a la DM i podia ajudar el pacient a ser més autònom en el maneig de la malaltia.

Va coincidir que sortien les tires de control glucèmic, les primeres del tot. Entre que allí hi havien assentades les bases per fer educació, les tires van donar una empenta més.

\section{Metge endocrinòleg}

Algunes comunicacions presentades als congressos mostren com la realització d'autoanàlisis s'utilitzava també com a estratègia per iniciar programes d'educació a pacients.

Comunicació presentada al Congrés ACDE 1988. Resum no publicat (Annex 10) 


\section{c) Suport institucional}

El suport en l'esfera política del Consell Assessor sobre la Diabetis a Catalunya i del Departament de Sanitat, com el d'algunes direccions de centres sanitaris, va ser decisiu en la implantació i el desenvolupament de l'ET.

\section{- Suport polític}

En aquell moment hi havia a Catalunya una ferma voluntat política de crear unitats de diabetis en els serveis d'endocrinologia i nutrició amb professionals ben preparats. La major part dels professionals entrevistats consideren que el Dr. Gonçal Lloveras, com a president del Consell Assessor sobre la Diabetis a Catalunya, va ser una figura cabdal en tot aquest procés, tant des del punt de vista del convenciment personal sobre l'educació del malalt diabètic, com del suport polític que rebia des de la Conselleria. El Dr. Josep Laporte era una persona sensibilitzada per la DM, ja que ell mateix la patia i no li va costar gens entendre la gran necessitat que hi havia de formació en DM i d'educació, tant dels professionals com dels mateixos malalts.

Aquí en Cataluña tuvo un papel fundamental el Consell Assessor de la Diabetis, concretamente en la figura del Dr. Gonçal Lloveras, que era una persona absolutamente convencida de la importancia de la educación y convencido del papel de la enfermera.

Dra. en Infermeria. Infermera experta en diabetes

El Consell Assessor sobre la Diabetis a Catalunya, liderat pel Dr. Lloveras, persona d'abordatge holístic, d’humanitats i una sensibilitat notable, de seguida ho va endreçar i ho va lligar al que era salut pública.

Infermera experta en diabetis

En Gonçal sempre havia defensat que el pacient havia de poder ser el gestor de la seva pròpia malaltia, $\mathrm{i}$ aquesta autonomia venia donada per l'educació. Com que en Gonçal tenia molt aquesta idea, igual que es va fer la comissió d'epidemiologia i la comissió d'assistència diabetològica, es va fer la comissió d'educació. Ell deia que l'educació no era una cosa que es podia improvisar, perquè si no, podria ser iatrogènica.

Metge endocrinòleg 
Des de l'IES, claríssimament n'hi havia de suport, i des del Departament de Salut, també. El Sr. Laporte, que era diabètic, era sensible a tot això. (...) Jo tinc aquesta visió, la visió de molt suport des de l'IES... També sabíem que era per part de persones concretes, per exemple, el Gonçal Lloveras, i l'Ignasi Juan Creix. El Gonçal va defensar l'Ignasi a capa i espasa.

\section{Metge endocrinòleg}

En aquells anys, des del Departament de Salut es potenciava el treball en equip entre metge i infermera, i l'educació sanitària per a la prevenció i el tractament de malalties cròniques com la DM. En aquest sentit, es va introduir també la figura de la infermera educadora de DM (les que s'havien format en els cursos de l'IES) com a professional referent d'aquesta patologia en molts centres d'APS. La bona entesa entre el Consell Assessor de la Diabetis i la Conselleria de Sanitat també va ajudar a crear unitats especialitzades amb una o més infermeres educadores de DM, així com a desenvolupar programes d'ET:

El Consell Assessor dona suport a la idea d'aquestes unitats, que després es van convertir en UDEN.

\section{Metge endocrinòleg}

Políticament i sanitàriament hi va haver unes estructures que van donar cobertura a la implantació de l'educació terapèutica.

\section{Infermera experta en diabetis}

A partir d'aquí, la infermera agafa un major protagonisme en el disseny i el desenvolupament de programes d'educació per a pacients i també per a altres professionals:

La potenciación de las enfermeras en Cataluña a nivel político fue excepcional; no en todos los sitios fue igual, y aquí tuvimos esta suerte. Esto hizo que se crearan unidades de diabetes, sobre todo en Atención Primaria Especializada (CAP II), y en todas las áreas básicas de Cataluña.

Dra. en Infermeria. Infermera experta en diabetis

En un principi potser no van ser les infermeres, però després crec que és la persona que ha liderat molts processos o molts programes i pot avaluar els resultats d'aquests programes i decidir si s'han de fer canvis o no.

\section{Infermera experta en diabetis}


En aquells moments era l'única persona en tot l'Alt Empordà que manejava la diabetis. Vaig actuar de referent, anava a reunir-me amb professionals de diferents CAP. Feia formació a altres professionals, tant metges com infermeres.

\section{Infermera experta en diabetis}

- Suport de les direccions dels centres sanitaris: El grau de suport va ser variable segons els centres. Inicialment gràcies a la influència a nivell polític, algunes direccions d'àrees sanitàries o centres sanitaris (hospitals o CAP) van ser sensibles a aquesta necessitat d'instaurar l'educació dels pacients en temes de salut, concretament en la diabetis i van facilitar els recursos mínims necessaris per iniciar el desenvolupament de programes educatius dins d'aquests centres, bàsicament espais més o menys adequats i la figura d'una o varies infermeres educadores a temps complert o parcial:

A Girona des de sempre hi va haver una sensibilitat tant de la institució per a l'educació als pacients com per als professionals.

\section{Metge endocrinòleg}

A l'hospital de Mataró érem un equip bastant vinculat a medicina interna, i deixebles, si no tots, del Dr. Jordi Gol. L'Albert Palaudaries va suggerir de fer una atenció endocrinològica, però també de les persones diabètiques en què s'havia d'incloure l'ensinistrament del malalt per poder anar-se'n a casa amb seguretat i amb coneixement i acompanyat de l'hospital. I aquesta idea va reeixir de seguida.

\section{Infermera experta en diabetis}

Tant la direcció d'infermeria com la direcció mèdica de l'hospital s'ho creien i a més s'hi comprometien.

Infermera experta en diabetis

Va ser l'any 84-85 que jo vaig venir a treballar al CAP de Figueres. Tenien força gent que anaven a buscar xeringues per punxar-se la insulina i em van proposar fer educació.

Infermera experta en diabetis

En tot cas, no sempre era fàcil, hi havia sensibilització en molts professionals, però alguna persona que va viure aquesta etapa des de l'administració sanitària té una opinió diferent respecte de la sensibilització de les gerències, direccions d'hospitals o CAP a l'hora de facilitar la formació dels professionals. 
No hi havia suport, per això la idea de l'Ignasi era: «Si fins i tot el gerent, la cap d'infermeria i la cap de compres fan el curs, tothom estarà sensibilitzat i tothom l'entendrà»; per això, ell volia que fins i tot anés el Conseller a fer el curs, tots.

\section{Metge endocrinòleg}

\section{d) La il·lusió i el voluntarisme}

Aquest és un dels punts centrals en el procés d'implementació de l'ET arreu del territori. El compromís social de l'època que es vivia també es traduiia en un compromís laboral lligat al descobriment de noves oportunitats professionals. La il-lusió de ser protagonistes d'un canvi en la manera de tractar els pacients va fer que els professionals s'impliquessin molt en aquesta transformació del model d'atenció. Hi havia moltes ganes de fer les coses d'un mode diferent i d'aprendre noves estratègies de tractament. Això va generar molt de voluntarisme tant en la formació dels professionals com a l'hora de posar en marxa projectes educatius. No importava tant el temps dedicat com les ganes d'aprendre i de veure els primers resultats.

Reconeixent que alguns endocrinòlegs van promocionar o afavorir la implantació de l'ET als pacients i van contribuir a promocionar i defensar el paper educador de la infermera, en la pràctica van ser prioritàriament les infermeres les que van dur a terme el lideratge dels programes d'ET i la investigació de l'efectivitat de l'ET. D'aquesta manera, la infermera adquiria dins de l'equip un protagonisme i una autonomia en els diagnòstics educatius, i de vegades en decisions de tractament, que eren altament motivadors. Un altre aspecte destacable és que el treball en equip va fomentar una relació més igualitària entre el metge i la infermera.

Algunes frases exposades a continuació mostrem com gairebé tots els professionals entrevistats expressen aquesta actitud de voluntat i d'il/lusió per ser protagonistes d'un canvi en la terapèutica de la malaltia.

Començàvem el curs divendres a la tarda i l'acabàvem diumenge al migdia. I la gent venia. Jo cada vegada que penso que la gent venia... Si això ho féssim ara, no vindria ningú. No ho dic per les persones, sinó per la situació global.

\section{Metge endocrinòleg}

Cuando terminó aquel curso de formación de profesorado, salimos todos con unas expectativas de cambio, con ganas de hacer cosas, de les cuales algunas se hicieron y otras no se pudieron hacer. Salíamos todos muy motivados y éramos un grupo que hacíamos muchas cosas, nos comunicábamos, organizábamos actividades. Cuando se hacían cursos íbamos de un lado a otro y creo que aquello fue fundamental para cambiar el concepto que teníamos de la educación.

Dra. en Infermeria. Infermera experta en diabetis 
Hi havia sensibilització i una gran vocació. Hi havia la il.lusió de començar una cosa necessària, perquè es veia necessària, nova, i les persones interessades van donar moltes hores del seu oci per implementar aquests programes que desprès sí que s'han pogut oficialitzar.

\section{Infermera experta en diabetis}

En la primera asociación las personas nos reuníamos en nuestras propias casas. Ofrecíamos nuestra vivienda como lugar de encuentro. También nuestro tiempo... Era como más voluntariado. (...) también es un momento en el que hay mucho entusiasmo, empieza a haber recursos pero tal vez también fue muy deprisa y no hubo contención... Era como una familia que se iba extendiendo y se iba multiplicando, pero había entusiasmo. Es lo que te digo, que aunque hubiera menos recursos, había mucho entusiasmo.

\section{Infermera experta en diabetis}

Amb molt entusiasme i amb il-lusió perquè estava a les nostres mans aportar canvi. Vaig anar a fer el curs a Perugia i m'ho vaig pagar jo i vaig demanar permís sense sou de l'hospital. Per tant, un grau de compromís hi era.

Infermera experta en diabetis

Amb formació de les companyes, amb informació dels llibres i amb molta eufòria vam posar les coses en marxa. Era un món fascinant!, vull dir que ens encantava. Hi va haver molt de voluntarietat per part nostra, perquè la direcció no ho tenia gaire clar. Aquesta figura era una despesa extra que havia de fer.

\section{Infermera experta en diabetis}

En el Clínico, un año antes de que yo me fuera se creó la figura de una enfermera a tiempo completo, hasta entonces no, era por voluntariado. Estuve siete años trabajando así...

\section{Dra. en Infermeria. Infermera experta en diabetis}

La formació i l'experiència que les infermeres anaven adquirint va començar a ser un recurs per a la indústria farmacèutica, que demanava la seva colllaboració en els programes de formació que patrocinaven.

També és veritat que hi havia laboratoris, d'insulines o de tires reactives, que ens buscaven per fer o per anar xerrades, vull dir, es van obrir moltíssimes portes i les agafàvem totes amb una il-lusió i unes ganes brutals. 


\section{e) El paper les associacions de pacients}

Les associacions de persones amb DM, igual que en altres malalties, han tingut un paper molt important en la informació i l'educació, però sobretot en la socialització de la malaltia, com la lluita per la integració social i laboral i la millora de la qualitat de vida dels pacients i els seus familiars. Diverses associacions arreu de Catalunya van néixer amb l'objectiu de sensibilitzar, tant els propis pacients com la societat, del que representa la malaltia. El seu principal interès era proporcionar informació sobre la DM, el seu tractament i com tenir-ne cura. Organitzaven bàsicament conferències en les quals participaven molts dels professionals (generalment, metges) relacionats amb la DM.

Malgrat no tenir dates concretes de la creació d'aquestes primeres associacions, s'han pogut trobar referències de les activitats que realitzaven a partir de la dècada dels vuitanta. Una de les més actives va ser l'Asociación de Diabéticos Catalonia (ADC), creada el 1979, amb seu al carrer Trafalgar, núm. 10, de Barcelona. El seu objectiu era informar i educar el malalt, cobrint així les deficiències assistencials i educatives que existien a principis dels anys vuitanta, i promoure l'autogestió de la malaltia. Es finançava a través de les quotes dels associats.

Durant els primers cinc anys de funcionament, pràcticament tots els conferenciants eren metges endocrinòlegs reconeguts de l'especialitat, però a partir del 1985 ja hi participen infermeres educadores, dietistes, podòlegs, etc., fet que demostra com s'havia anat consolidant la visió interdisciplinària del tractament de la DM, i sobretot la importància que adquiria la infermera educadora en DM. S'han pogut conèixer les seves activitats gràcies a la divulgació que en feien a través de la premsa. A continuació se'n detallen algunes:

El Centro de Diabéticos Catalonia organiza las II Jornadas de Información para las personas que sufren esta enfermedad. El día 20, domingo, en sesiones de mañana y tarde, en el Palacio de Congresos de Montjuic, se desarrollarán diez conferencias, que abarcarán los siguientes temas: formas de diabetes, predisposición y prevención, tratamiento por medio de la farmacología, medios dietéticos, objetivos a conseguir, evolución y consecuencias de la enfermedad, autocontrol, control de glucemia (con demostraciones de medidores), variantes en la diabetes infantil, circunstancias psicológicas y consejos para la preparación de comidas. El Centro Catalonia se ha impuesto la misión de informar, orientar y ayudar al diabético y en el año que funciona ha obtenido positivos resultados, sin más recursos que los de sus propios adheridos ${ }^{257}$.

Il Conferencias para Diabéticos: Organizadas por el Centro de Diabéticos Catalonia, mañana domingo y en el Palacio de Congresos tendrán efecto las II Conferencias d’Información para Diabéticos, en las que se tratarán todos los aspectos relativos a esta enfermedad y los cuidados que requiere. Disertarán destacados especialistas, tales como los doctores Cañadeil Vidal, Calvet Francés, Masriera Segalés, Coronas Alonso, Viguera Montesinos y Montero Albalat; los señores Moyá Argeler, Bonet Saura y la señorita Angeles Rihé Pijoan. ${ }^{258}$ 
L'ADC va treballar en diferents aspectes:

- Minimitzar l'impacte social de la malaltia

S'hi donava força valor, com es pot apreciar en el titular d'un diari, «El diabético no es un enfermo», on s'informava del nous avenços tecnològics, com els nous mesurados de glucosa capilar que facilitaven el control de la glucemia a domicili, la bomba d'insulina, la fotocoagulació amb làser i la microcirurgia ocular

El Dr. Muiños, un hombre enamorado de su profesión, como dice, dio un encanto especial a su disertación y en el marco científico de la misma resaltaron los valores de la microcirugía ocular y el gran progreso que la misma representa para asegurar y recuperar visión a los afectados de retinopatías diabéticas por modernos procedimientos de fotocoagulación por rayos láser y vitrectomías... 259

En una altra conferència, tres anys més tard, anunciada també al diari, en què es parlava de la nutrició en la DM, es pretenia normalitzar i socialitzar els plans d'alimentació fent ús de tècniques educatives per facilitar la comprensió (época de gran influència del grup de Suïssa), com era la demostració visual de plats preparats.

Durante la reunión se sucederán conferencias, coloquios y discusiones, todas ellas con el tema central de la nutrición, y se presentará un gran buffet con numerosos platos preparados, todos los que componen la dieta habitual, como los que ya no son tan típicos y los que podrían servirse en una comida de día extraordinario. Los participantes son destacados médicos especialistas en nutrición, dietética y endocrinología ${ }^{260}$.

\section{- Fomentar l'autogestió del tractament}

En molts dels anuncis de les seves activitats es volia transmetre la responsabilitat que té el pacient en la l'autogestió de la malaltia i la importància de l'educació en aquest procés.

El diabético puede y debe influir en su enfermedad. Así lo ha estimado desde su fundación el barcelonés Club de Diabéticos Catalonia, que es una asociación promocional y educativa de aquellos que han contraído esta enfermedad, que va a poner en marcha un programa de servicios complementarios a disposición de los diabéticos de Barcelona y próximamente en otras localidades. Además, se preocupa de cubrir la falta de información precisa sobre el mal que, en muchos casos, ha llevado a un desconocimiento de su trascendencia para la sociedad e, incluso, para los propios afectados. 
Por ello, es el propio diabético quien debe controlar todos los factores que intervienen en su compensación tales como nutrición, horarios y ejercicio físico, para poder efectuar por sí mismo los ajustes en la dosificación del tratamiento que le permitan mantener en equilibrio unos valores lo más estables posible de glucosa en su sangre ${ }^{261}$.

En el acto de esta noche en Montjuic, además de una introducción del presidente de la asociación, Tomás Pérez Caldés, serán objeto de estudio por parte de destacados especialistas, los siguientes temas: «Necesidad de la información especial del diabético», «Presente y futuro de la educación del diabético», «Nueva orientación de las actividades de la Asociación hacia la información especial del afectado», y presentación específica del programa ${ }^{262}$.

- Assessorament en tots els problemes relacionats amb la malaltia

L'èmfasi queia en els assumptes relacionats amb l'entorn laboral, on la diabetis sempre ha estat, però més en aquella època, una dificultat per aconseguir o mantenir el lloc de treball.

La ADC, que nació ahora hace seis años con el noble propósito de informar y educar al enfermo de diabetes, está abierta a todo tipo de consultas para hacer más electivo y humano el tratamiento integral del diabético. Junto con la dieta, medicación, ejercicios físicos y autocontrol. Esta labor educativa, vital para aliviar las complicaciones de los enfermos se presta sin el menor ánimo de lucro y el cuadro orientativo está integrado por un equipo de profesionales (médico-endocrinólogo, técnicos en dietética, educadores en diabetes, etc.). Se dispone también de un gabinete de asesoría laboral263.

\section{- La creació d'un carnet identificatiu}

El 1986 van crear un «Carnet d'identificació per a persones amb diabetis» per tal de garantir que davant qualsevol situació de risc, com ara una hipoglucèmia, se'ls pogués donar l'atenció adequada.

Catalonia Asociación, que cumple una generosa y eficiente labor de asesoramiento y asistencia al diabético, ha creado un carnet de alerta médica para quienes padecen esta enfermedad. Es un documento que se extiende gratuitamente y en el cual, además del nombre, domicilio, grupo sanguíneo y otros datos de interés, se anota el tratamiento médico que sigue el enfermo, el facultativo que le atiende, etc. Se trata, sin duda, de un carnet que comno medida preventiva deberían llevar encima todas las personas que tienen algún grado de diabetes ${ }^{264}$.

Els presidents d'aquesta associació van ser membres actius de l'Associació Catalana d'Educadors en Diabetis, i més tard de l'Associació Catalana de Diabetis, i hi va destacar el nom del Sr. Josep M. Adell. 


\section{f) El paper de l'Associació Catalana d'Educadors en Diabetis}

\section{- Creació de l'Associació Catalana d'Educadors en Diabetis}

El 12 de novembre del 1984 es va constituir l'Associació Catalana d'Educadors en Diabetis (ACED), una agrupació sense finalitats lucratives. Va néixer com a resultat de la voluntat d'un grup de metges, infermeres i dietistes que estaven treballant en aquest tema en diverses institucions. La primera reunió de l’Associació va ser el gener de 1985.

El president va ser el Dr. Josep Pla Bartina. Els Estatuts es van registrar en el Registre d'Associacions de Barcelona, amb el número 7598, el 6 de juny del 1985 (Annex 11).

Raó d'ésser : Es considera l'Educació Diabetològica com a part fonamental de la tasca de prevenció i tractament de la diabetis. En aquest sentit l'Educació Diabetològica s'inscriu dins del concepte d'Educació Sanitària com a instrument ineludible de promoció de la salut.

La seu inicial va quedar fixada a Barcelona, a l'Hospital Clínic, a la Secció de Diabetis, i l'àmbit d'acció serà el territori geogràfic de la Comunitat Autònoma de Catalunya. A partir del 27 de febrer del 1990, la nova adreça de l'ACED va ser la de l'Acadèmia de Ciències Mèdiques, al Passeig de la Bonanova.

Els membres de l'Associació podien ser metges, infermeres, dietistes i qualsevol professional que pogués acreditar una tasca seriosa, eficaç, responsable i basada en realitzacions objectives d'instrucció a la persona amb DM (pedagogs, assistents socials, psicòlegs, etc.).

\section{- Objectius que es va proposar l'ACED}

A. Millorar la qualitat de vida de la persona amb DM, ajudant-lo a ser autònom i facilitant-li I'adherència al tractament.

B. Desenvolupar programes d'educació per a les persones amb DM.

C. Estudiar i aplicar metodologies que facilitin l'aprenentatge a les persones amb DM.

D. Avaluar i acreditar els mètodes i sistemes educatius tant grupals com individuals (cursos, publicacions, colònies, audiovisuals, etc.).

E. Promoure cursos especialitzats per a educadors en DM, així com mecanismes d'educació continuada, facilitant a la sanitat pública, i alhora exigint-li uns mecanismes de progressiva acreditació, titulació i professionalització d’aquesta tasca, dedicant-hi els recursos econòmics necessaris. 
F. Incidir en el fet que l'educació diabetològica s'implanti en els diferents nivells d'atenció.

G. Fomentar la investigació específica en educació diabetològica.

H. Informar la població en general dels riscos individuals i col-lectius de la DM i dels avantatges d'una tasca preventiva, emfatitzant l'educació alimentària.

I. Mostrar que la inversió en educació diabetològica suposa una reducció del cost social de la DM.

\section{- Contribució de l'ACED a l’Educació Diabetològica}

- Alimentació:

- Formació en dietètica: 1986 «Tallers de Dietètica»: Els professionals tenen la necessitat, per manca de dietistes al seu medi de treball, de realitzar educació dietètica als seus pacients i, per tant, demanen un document de consens sobre com s'ha de treballar l'alimentació en el pacient amb DM.

- Interès per unificar les taules de composició d'aliments existents: s'encarregà la confecció d'una proposta d'unificació de paràmetres alimentaris, en concret de:

- Els valors de glúcids, lípids i proteïnes dels aliments: Els valors que adjudicaven diferents taules de composició eren diferents. Es va proposar arrodonir-los per tal de facilitar-ne l'ús pràctic. Es va fer palesa la utilitat d'unificació a l'Estat espanyol, a fi d'evitar les nombroses petites diferències, de no gaire importància teòrica, però que en la pràctica dificultaven els treballs dels equips assistencials i confonien els pacients.

- Llistes d'equivalents dels diferents grups d'aliments: després de consultar les principals taules de composició d'aliments, com RANDOIN L, DOCUMENTA GEIGY, US DEP. AGRICULTURE, PAUL AA SOUTHGATE DAT, VARELA G, així com els treballs publicats pel grup del Dr. Rojas Hidalgo, i de contrastar els valors aportats per altres grups d'assistència i educació diabetològica espanyola i els equivalents de l'ADA, es va proposar adoptar la quantitat de $10 \mathrm{~g}$ com a valor assignat a una ració de glúcids, lípids i proteïnes, és a dir, es tractaria de buscar els pesos dels diferents aliments que continguessin $10 \mathrm{~g}$ del principi immediat corresponent. Aquest treball es va presentar al II Congrés de la FEAED, el 3 de maig del 1986 (2a Circular informativa de l'ACED, octubre de 1986) (Annex 12). 


\section{- Formació en pedagogia per a l’educació en DM:}

En ple procés de formació en pedagogia de l'educació sanitària, l'ACED i l'IES van promoure una sèrie de conferències de persones rellevants en aquell moment en el camp de la pedagogia. Donada la gran influència dels grups italians d'educació sanitària, com els de I'Escola de Perugia i els de l'escola suïssa del prof. Assal, es va fer una sèrie de conferències extraordinàries, com la del professor Maurizio Mori, al qual es va convidar per coordinar el 6è stage del curs de Formació de Professorat en Educació Diabetològica (Annex 13), i la de la professora Anne Lacroix (Annex 14). En totes aquestes activitats, el suport del Departament de Sanitat de la Generalitat de Catalunya i del Consell Assessor sobre la Diabetis a Catalunya va ser innegable.

\section{- Fomentar la recerca:}

- Es van organitzar «reunions» anuals (congressos) amb la intenció de promoure activitats de recerca en educació diabetològica i donar a conèixer els resultats de la investigació. Hi participaven professionals de diferents nivells assistencials i de diferents collectius, com infermeres, metges, dietistes. Per exemple, l'any 1988, segons el llistat d'assistents a la III reunió de I'ACED, celebrada a Puigcerdà, dels 78 professionals inscrits, 42 eren metges i infermeres d'hospitals, 29 de CAP i 7 d'altres centres privats.

- Es va instaurar un premi d'educació diabetològica, el Premi d'Educació Sanitària Aplicada a la Diabetis de l'ACED, dotat amb 150.000 pessetes.

Es valorarà com a mèrit preferent, aquell treball que presenti una experiència en educació diabetològica i que el seu contingut pugui ser d'utilitat per millorar l'atenció al malalt diabètic per davant dels treballs que presentin un projecte.

Document de la convocatòria del I Premi d'Educació Sanitària Aplicada a la Diabetis de l'ACED. Barcelona, juny del 1989 (Annex 15)

L'any 1991 aquest premi es va atorgar a la Sra. Margarida Jansà, infermera experta en diabetis del Servei de Diabetologia de l'Hospital Clínic de Barcelona, que va presentar el treball: «Mesurador d'aliments cuits adaptat per a 2 racions de $10 \mathrm{~g}$ d'hidrats de carboni»

\section{- Intentar obtenir l’acreditació de la infermera experta en DM}

Val la pena destacar que l'ACED va treballar en l'àmbit institucional per la formació i l'acreditació dels educadors en DM. Es basava en la idea que l'educació de pacients no és patrimoni exclusiu de cap estament professional, i que l'educació s'ha d'incorporar de manera simultània i superposada a l'assistència. Tots els professionals de l'equip assistencial, des de l'administratiu que programa les visites fins al metge resident, tenen un paper educador. 
Per tant, partint d'aquest marc conceptual, el que es buscava no era un títol d'educador, sinó la figura de la infermera experta en diabetis, com a membre integrant de l'equip mínim bàsic en el nivell d'especialitat (metge diabetòleg i infermera experta en diabetis) i amb una formació en tres grans àmbits:

- Diabetologia

- Educació Sanitària

- Nutrició

Es va proposar que dins la Sanitat Pública es creessin places perfilades per a aquesta infermera. Així es va expressar en els estatuts de l'ACED:

\footnotetext{
Promoure cursos especialitzats per a educadors en diabetis i mecanismes d'educació continuada, facilitant a la sanitat pública i exigint-li a la vegada uns mecanismes de progressiva acreditació, titulació i professionalització d'aquesta tasca, dedicant a la mateixa els recursos econòmics necessaris.
}

Quart objectiu dels Estatuts de l'ACED, 1985 (Annex 11)

Es buscava també una definició del perfil de l'educador i del seu paper en l'equip assistencial. El 1985 es van organitzar conferències i debats per discutir sobre aquest tema. A la primera hi va estar convidat el prof. Rufino, que va parlar sobre el «perfil de l'educador».

El mes de juny passat, coincidint amb el Primer Curs de Perfeccionament en Educació Diabetològica, l'ACED en col-laboració amb el Consell Assessor sobre la Diabetis a Catalunya, va organitzar una conferencia del prof. Guido Rufino sobre el «Perfil del Educador». El prof. Rufino, com és habitual en ell, va extreure del públic una sèrie de preguntes i reflexions sobre la figura de l'educador que feren descobrir als que assistirem nous aspectes i dimensions del educador.

2a Circular informativa de l'ACED, octubre del 1986

El 1989, en la V Reunió Anual de l'ACED, celebrada a Igualada, la Junta va proposar formar una societat única, resultat de la fusió de l'ACED, la Societat Catalana de Diabetis (SCD) de l'Acadèmia de Ciències Mèdiques de Catalunya i Balears, en la qual tots els membre eren metges, $\mathrm{i}$ I'Associació de Diabètics de Catalunya (ADC), amb la idea de representar amb més força l'ampli espectre de persones que a Catalunya treballaven en i per a la diabetologia i perquè se' $n$ facilités el reconeixement internacional.

\subsubsection{Canvis produïts en l'assistència a la diabetis}

Als inicis dels anys vuitanta, la gran quantitat de professionals que arreu de Catalunya es van anar formant per millorar l'atenció tant clínica com educativa de les persones amb DM, gràcies 
al convenciment de les autoritats sanitàries i el suport majoritari de les direccions d'infermeria i mèdiques de molts centres hospitalaris o d'AP, va permetre:

\section{a) Demanar els recursos mínims per iniciar programes d'educació en els llocs on no s'estava fent res}

Els recursos mínims necessaris eren professionals que es dediquessin a l'educació i un espai adient dotat, al menys, de taula i cadires. No a tot arreu es va aconseguir el nombre suficient de professionals per fer educació ni els espais apropiats, i cadascú buscava amb una gran dosi de voluntarietat allà on pensava que podria obtenir els recursos de la millor manera possible.

A Tarragona, per exemple, va ser un metge motivat, el Dr. Bernardo Costa, qui va elaborar els programes d'educació i qui feia d'educador, acompanyat d'alguna infermera. En altres llocs van ser els endocrinòlegs els que van lluitar per aconseguir la figura de la infermera educadora en les unitats de diabetis.

Després vaig anar a Lleida perquè jo soc d'allà. En arribar no hi havia res de res i amb la Isabel Martínez vam començar a anar fent entre les dues. En aquell moment, que la cap d'infermeria era una persona molt més lluitadora, però lluitadores per la professió, ens va ajudar i vam poder crear la figura de la infermera només dedicada a l'educació. Vam aconseguir educadora al matí, a la tarda. Vam aconseguir dietista, espais, podíem fer classes en grup.

\section{Metgessa endocrinòloga}

En comarcas no había nada. Fue una época muy difícil, porque estamos hablando del 86-87, y en este momento, por ejemplo Tarragona, tiene unos indicadores de atención al diabético patéticos. Se hacía lo que se podía, no había prácticamente venta de tiras de glucosa en sangre, todo era glucosuria mientras que en otros sitios se utilizaban cada vez más. Entonces la propuesta que yo hice a mi jefe de servicio era hacer una unidad de diabetes. Una unidad, nunca mejor dicho, porque era de una persona, ya que no había dinero. Y montamos una unidad de diabetes. Yo solamente necesitaba el permiso del jefe de medicina interna.

\section{Dr. Bernardo Costa}

\section{b) Passar del voluntarisme a l'estructura i organització de l'educació diabetològica}

A finals dels vuitanta ja hi ha un grup notable d'infermeres i alguns metges d'arreu de Catalunya formats en educació diabetològica. Molts eren companys dels mateixos equips d'hospitals o de CAP. Amb la il·lusió i la convicció de canviar l’atenció a les persones amb DM, es va implantar la figura de la infermera educadora en molts CAP, especialment en els anomenats CAP II, que eren centres on visitaven els especialistes, entre els quals, els endocrinòlegs. També es va implantar aquesta figura en els serveis d'endocrinologia o diabetologia dels hospitals. Així mateix, i fruit 
de l'aprenentatge rebut, es desenvolupen a ambdós àmbits programes d'educació dirigits tant a pacients com a altres professionals amb l'objectiu de millorar el control i unificar criteris en l'atenció a la DM.

L’any 1986 es va iniciar a l'Hospital Mútua Terrassa un programa d'educació a pacients amb DM dirigit al sector d'actuació de l'esmentat hospital, les poblacions de Terrassa, Rubí i Sant Cugat, amb tres nivells de dificultat en funció dels tipus de DM i de les característiques dels pacients. Aquest programa, avalat per l'ACED l'any 1990, va estar nomenat pel Consell Assessor sobre la Diabetis a Catalunya com d'alta qualitat, rigor tècnic i d'especial interès per la sistematització de la metodologia educativa en DM (Annex 16).

\section{c) Investigació en l'àmbit de l'educació terapèutica}

Aviat sorgeixen els resultats sobre la implementació i l'eficàcia dels programes d'educació diabetològica respecte de la millora del control metabòlic i la reducció d’hospitalitzacions ${ }^{265,266,267}$, l'increment de coneixements de la població diabètica assistida, la prevenció de les complicacions, així com també de la metodologia de l'educació i de la capacitat de coordinació entre els diferents nivells d'assistència. Molts d'aquests resultats van ser motiu de presentacions a congressos tant d'àmbit estatal com d'aquí a Catalunya, per part dels professionals dedicats a l'educació de les persones amb DM, i alguns van ser publicats en revistes de divulgació científica.

A la taula 1 es recullen les comunicacions presentades a la IV Jornades de l'ACED celebrades a Sabadell el 10 de desembre de 1988, on es pot veure que la majoria de comunicacions presentades reflectien l'interès per censar la població diabètica, desenvolupar i aplicar programes d'educació implicant-hi també l'APS, la qual estava en ple procés de desenvolupament, com ja s'ha comentat. Tot i que la infermeria ja liderava en la majoria de centres els programes d'educació diabetològica, encara eren majoritàriament els metges els que presentaven les comunicacions als congressos. La infermeria estava desenvolupant la seva capacitat investigadora i pocs anys després ocupava la gran majoria de presentacions sobre educació terapèutica, bàsicament en els congressos nacionals. 
Taula 1: Comunicacions presentades a l'ACED (IV Jornada de I'ACED, Sabadell, 1988)

\begin{tabular}{|l|l|}
\multicolumn{1}{|c|}{ Títol de les comunicacions } & \multicolumn{1}{|c|}{ Autors / Centres de treball } \\
$\begin{array}{l}\text { Estrategia para el inicio de un programa } \\
\text { educativo }\end{array}$ & $\begin{array}{l}\text { Masoliver JR, Surroca M. Carrasco R, Puig } \\
\text { M, Guasch V. Hospital Sagrat Cor. Barce- } \\
\text { lona }\end{array}$ \\
\hline $\begin{array}{l}\text { Tallers de Diabetologia. Experiència prèvia, } \\
\text { problemàtica i expectatives dels assistents }\end{array}$ & $\begin{array}{l}\text { Sans JM, Pagés A, Rodriguez A, Sedano P. } \\
\text { Programa diabetis Creu Roja Tarragona }\end{array}$ \\
\hline $\begin{array}{l}\text { Importància d'Infermeria en l'aplicació d'un } \\
\text { programa educatiu dirigit al malalt ingressat }\end{array}$ & $\begin{array}{l}\text { Vidal N, Rodriguez L, Ara P, Capillas R. Ser- } \\
\text { vei d'Endocrinologia i Diabetis. Hospital } \\
\text { Clínic de Barcelona }\end{array}$ \\
\hline $\begin{array}{l}\text { Estat actual del cens de diabètics i de l'edu- } \\
\text { cació diabetològica a la Cerdanya }\end{array}$ & $\begin{array}{l}\text { Cardona M, Subirats E, Vila T, Margalef } \\
\text { N, Vila LI. Hospital de Puigcerdà - Centre } \\
\text { Hospitalari de la Cerdanya }\end{array}$ \\
\hline $\begin{array}{l}\text { Estudi de la no freqüentació dels pacients } \\
\text { diabètics censats en un centre d'assistència } \\
\text { primària }\end{array}$ & $\begin{array}{l}\text { Altayó M. Elena, Alerm J, Arroyo J. CAP I } \\
\text { Concòrdia CAP II St. Fèlix. Sabadell }\end{array}$ \\
\hline $\begin{array}{l}\text { Educació Diabetològica a Tarragona: Implica- } \\
\text { ció de l'Assistència Primària }\end{array}$ & $\begin{array}{l}\text { Costa B, Olesti M, Boqué N, Barrera N, } \\
\text { Tlamo C, Pérez C. Programa d'ED ICS } \\
\text { Miró; Tarragona: CAP Av. Catalunya i Hos- } \\
\text { pital Joan XIII }\end{array}$ \\
\hline
\end{tabular}

Font pròpia: Elaboració a partir dels programes dels congressos

\section{d) La coordinació institucionalitzada entre els professionals dels diferents nivells assistencials per tal d'unificar criteris i promoure la continuïtat de l'assistència tant en l'àmbit hospitalari com en l'APS.}

Atès que s'estava implantant la xarxa d'APS a tot Catalunya, alguns professionals de l'AP sentien que se'ls havia d'implicar més en l'elaboració dels programes educatius.

Sería deseable, pues, que a la hora de diseñar y poner en marcha programas educativos, se tuviera en cuenta y se propiciara la colaboración de los profesionales de Atención Primaria a fin de aumentar la cobertura y la eficacia de los mismos y de disminuir la tradicional incomunicación existente entre los distintos niveles sanitarios ${ }^{268}$. 
Però també des de l'administració sanitària es veia la necessitat d'endreçar i coordinar l'atenció de la població diabètica, i es van elaborar programes d'àmbit sectorial coordinats i supervisats per professionals de cada àrea en concret. Els aspectes més destacables d'aquests programes eren la interdisciplinarietat i la gran importància que es donava a l'educació i a la figura de l'educador en DM, però a la vegada hi havia un gran interès a potenciar i dotar de recursos la xarxa d'APS.

Des del 1988 fins al 1992, algunes àrees sanitàries, com ara l'Àrea 7 Centre, van organitzar cursos de DM i educació per a infermeres i metges, especialment de l'AP, i intentaven promoure la coordinació dels diferents nivells assistencials a fi de millorar l'atenció de les persones amb DM. L'Àrea 7 Centre estava formada per quatre sectors: 1: Manresa-Berga, 2: Sabadell-Cerdanyola, 3: Terrassa-Rubí-St. Cugat, i 4: Granollers-Vic-Mollet. Els objectius del programa eren els següents:

- Oferir un marc de discussió als professionals implicats sobre la planificació i programació de l'atenció al diabètic en tota l'àrea de Gestió Centre.

- Conèixer l'estructura d'atenció al diabètic i detectar els problemes més importants.

- Definir els criteris d'atenció necessaris i la seva qualitat.

- Definir la relació entre nivells assistencials i la seva comunicació i dependència.

- Establir els criteris de formació continuada en DM dels professionals implicats i fer-ne una proposta a llarg termini.

- Promocionar la investigació epidemiològica, clínica, educativa, etc. i operativa dels actuals serveis assistencials.

Es van treballar temes com:

- Els registres: la fitxa HCAP (història clínica d’atenció primària), per tal de tenir un sistema de control del consum de prestacions, com ara:

- nombre de persones tractades amb insulina

- nombre de persones que realitzaven autoanàlisi de glucèmia capil·lar i quins sistemes utilitzaven

- Protocols: criteris diagnòstics de DM, criteris diagnòstics de la test de tolerància oral a la glucosa (TTOG), recomanacions prèvies de la TTOG, normes per realitzar la TTOG, classificació de la DM.

- Formació de professionals: organització de diversos cursos de formació interdisciplinària per a professionals de I'APS d'aquesta àrea sanitària.

No obstant, la inversió en aquests programes per part del Departament de Salut no semblava eficaç, ja que la visió majoritària dels professionals era que hi havia molt poca coordinació entre els diferents nivells assistencials, tal com queda reflectit en diferents publicacions: 
En lo referente a la relación entre niveles de atención al diabético, existe práctica unanimidad en considerar que nuestros hospitales están mal comunicados con la atención primaria o viceversa. Es la única cuestión que no dejó a nadie indiferente... ${ }^{269}$

\subsubsection{De la dècada dels noranta fins a l'actualitat. Evolució de l'educació terapèutica en diabetis a Catalunya}

Als inicis dels anys noranta es vivia un moment en què les autoritats sanitàries demostraven interès per l'atenció a la persona amb DM (assistència mèdica + educació). La tasca duta a terme per fomentar i promoure la formació tant en DM com en educació sanitària va influir positivament en la qualitat de la formació. Es buscava que aquesta formació provoqués canvis en l'estil professional, de manera que afavorís la formació d'equips de treball, a més del desenvolupament de programes d'educació i d'atenció integral a la persona amb DM. Es pot observar a la taula 2, sobre presentacions de treballs a congressos, com els primers anys de la dècada dels noranta el principal interès era la implementació de programes més bàsics i generals sobre educació en la DM i la seva avaluació. Cap a la meitat de la dècada ja s'aplicaven programes més específics, que seran els principals reptes educatius, com són l'alimentació o el peu diabètic. I ja cap a finals de la dècada, quan els programes adreçats a millorar el coneixement de la malaltia per facilitar el canvi d'hàbits no donaven els resultats desitjats, va créixer la preocupació pels problemes psicològics dels pacients, l'actitud de professionals i pacients davant l'educació i altres aspectes referents a la qualitat de l'atenció com a element que pot intervenir positivament o negativament en l'adherència al tractament.

Taula 2. Treballs presentats a congressos. Dècada dels noranta

\section{Jornada ACED Castelldefels (any 1991)}

\begin{tabular}{|l|l|}
\hline Títol de les comunicacions & Autors / Centres de treball \\
\hline \multirow{2}{*}{ La publicidad y la salud } & $\begin{array}{l}\text { Isla P., López C., Icart T., Roige A. } \\
\text { EUI Dept. Salut Pública, Salut Mental } \\
\text { i Materno-infantil. Universitat de } \\
\text { Barcelona }\end{array}$ \\
\hline $\begin{array}{l}\text { Educació grupal en pacients de nivell } \\
\text { avançat }\end{array}$ & $\begin{array}{l}\text { Riera M, Valverde M, Millán M, Anglada } \\
\text { J, del Pozo C, Viladot A, Guitard A. } \\
\text { Hospital Mútua Terrassa, CAP II Terrassa. } \\
\text { Ambulatori St. Cugat }\end{array}$ \\
\hline
\end{tabular}




\begin{tabular}{|c|c|}
\hline $\begin{array}{l}\text { Atención multidisciplinar en el pie } \\
\text { diabético }\end{array}$ & $\begin{array}{l}\text { Santamaria E. Hospital de Bellvitge. } \\
\text { Servicio de Cirugia Plástica }\end{array}$ \\
\hline Taller de dietas & $\begin{array}{l}\text { Capitán A, Fabré M, Fuentes R, Maura P, } \\
\text { Paramo C, Torres M. CAP Drassanes }\end{array}$ \\
\hline $\begin{array}{l}\text { Evaluación del paciente diabético } \\
\text { ingresado }\end{array}$ & $\begin{array}{l}\text { Rodriguez L, Vidal N, Ara P, Jansà } \\
\text { M, Bailo I, Pastor L, Isla P. Unitat } \\
\text { d'Endocinologia i Nutrició, Hospital } \\
\text { Clínic. Escola Universitària d'Infermeria, } \\
\text { Dpt. Salut Pública, Universitat de } \\
\text { Barcelona }\end{array}$ \\
\hline $\begin{array}{l}\text { Avaluació d'un curs de podologia aplicat } \\
\text { a la diabetis }\end{array}$ & $\begin{array}{l}\text { Alerm J, Viade J, Soler F., Urrutia L, } \\
\text { Rodríguez D, Arroyo J. Ärea de Gestió } 7 \\
\text { Centre. Sector Sabadell }\end{array}$ \\
\hline $\begin{array}{l}\text { Resultats a mig termini de l'educació } \\
\text { diabetològica entre els diferents nivells } \\
\text { d'assistència }\end{array}$ & $\begin{array}{l}\text { Valverde M, Millán M, Riera M, Cano } \\
\text { S, Sauló R, Anglada J. Hospital Mútua } \\
\text { Terrassa, CAP II Terrassa. Ambulatori St. } \\
\text { Cugat }\end{array}$ \\
\hline Curs d'informació per a diabètics & $\begin{array}{l}\text { Viladot A, Salvador G, Adell JM, Pérez } \\
\text { A. Federació Catalana d'Associacions de } \\
\text { Diabètics (FECADI) }\end{array}$ \\
\hline $\begin{array}{l}\text { Resultats enquesta de coneixements i } \\
\text { actituds en diabètics tipus } 2\end{array}$ & $\begin{array}{l}\text { Adell R, Calvet J, Campama I, García } \\
\text { R, Gómez I, Micaló T, Murillo N. ABS } \\
\text { Castelldefels }\end{array}$ \\
\hline $\begin{array}{l}\text { Curs d'Informació Diabetològica de } \\
\text { FECADI: «La Dieta del Diabètic» }\end{array}$ & $\begin{array}{l}\text { Salvador G, Reig D, Olmos M, Mata } \\
\text { E, Pio E, Viladot A, Adell J. M. FECADI } \\
\text { (Federació Catalana d'Associacions de } \\
\text { Diabètics) }\end{array}$ \\
\hline \multicolumn{2}{|c|}{$\begin{array}{l}\text { III Congrés de l'Associació Catalana de Diabetis (any 1995) } \\
\text { (Comunicacions orals presentades a la Sessió d'Educació Diabetològica) }\end{array}$} \\
\hline $\begin{array}{l}\text { Estudi pilot de detecció dels hàbits } \\
\text { incorrectes en les cures del peu diabètic, } \\
\text { en la població de Ciutat Vella }\end{array}$ & $\begin{array}{l}\text { Páramo C, Castells A, Torres M, Capitán } \\
\text { A, Conill M, Durall A. CAP Drassanes, } \\
\text { CAP Ciutat Vella }\end{array}$ \\
\hline
\end{tabular}


Sistematització de les cures del peu diabètic complicat

Baños A, Martínez A, Rimbau V. Cirurgia cardiovascular. Hospital Clínic. Barcelona

Peu diabètic complicat dins una gran ciutat

Martínez A, Baños M. Cirurgia

cardiovascular. Hospital Clínic. Barcelona

Avaluació d'un programa de prevenció de lesions al peu per a diabètics amb neuropatia i/o vasculopatia

Yoldi C, Vidal $M$, Jansà $M$, Ara $P$, Yago G, Rodríguez L, López MC, Manzanares JM. Servei d'Endocrinologia i Nutrició. Hospital Clínic. Barna

Valoració del calçat del pacient diabètic a un CAP

Grup de Treball dels Educadors en Diabetis del Vallès Oriental. Direcció d'Atenció Primària de Granollers, CAP Vallès Oriental

Dieta qualitativa sense utilització de textos

Balsells N, Mayoral I, Camps I.

CAP Prat de la Riba. Lleida. Servei d'Endocrinologia. Unitat d'Educació Diabetològica

Detecció i correcció d'errors en el procés d'autoanàlisi amb reflectòmetre

Cano A, Esquius E, Millán M, Urbano $P$, Valverde T, Anglada J. CAP II. Hospital Mútua Terrassa

Estudi comparatiu dels efectes de l'educació individual i grupal sobre I'HbA1c i IMC

Almagro MJ, Sardá P. Hospital Universitari St. Joan. Reus

Inici d'un programa d'educació per a la diabetis gestacional en un CAP II

Mayoral I, Balsells N, Camps I. CAP II Prat de la Riba. Lleida

IV Congrés de l'Associació Catalana de Diabetis (any 1997) (Comunicacions orals presentades a la Sessió d’Educació Diabetològica)

Perfil psicològic en un grup d'adolescents amb diabetis mellitus tipus 1. Relació amb l'educació diabetològica i el control metabòlic
Castells I,Pérez C, Riera Y, Fabregà

C, Lucas A,Tarragó R. Servei

d'Endocrinologia. Hospital Universitari

Germans Trias i Pujol. Badalona 


\begin{tabular}{|c|c|}
\hline La satisfacció dels diabètics tipus 1 & $\begin{array}{l}\text { Insa R, Juanola MD, Boltaña A, } \\
\text { Fernández M. Servei d'Endocrinologia. } \\
\text { Ciutat Sanitària i Universitària de } \\
\text { Bellvitge. L'Hospitalet de Llobregat. } \\
\text { Escola Universitària d'Infermeria. Vall } \\
\text { d'Hebron. Barcelona }\end{array}$ \\
\hline $\begin{array}{l}\text { Com avaluar la percepció i els } \\
\text { coneixements sobre diabetis de les } \\
\text { infermeres }\end{array}$ & $\begin{array}{l}\text { Valverde M, Millán M, Urbano P, García } \\
\text { L, Cano S, Esquius E, Riera M. Servei } \\
\text { d'Endocrinologia. Hospital Mútua } \\
\text { Terrassa. Terrassa }\end{array}$ \\
\hline $\begin{array}{l}\text { Impacte psicològic del cribatge de la } \\
\text { prediabetis de tipus } 1\end{array}$ & $\begin{array}{l}\text { Vidal M, Úbeda J, Rodríguez C, Jansà M, } \\
\text { Díaz L, Durán C, Maria MA, Martín E, } \\
\text { Puig M, Conget I. Sevei d'Endocrinologia } \\
\text { i Diabetis i Servei de Psiquiatria. Hospital } \\
\text { Clínic i Universitari. Clínica Diabetològica. } \\
\text { Hospital de la Sta. Creu i St. Pau }\end{array}$ \\
\hline Què significa tenir una diabetis? & $\begin{array}{l}\text { Isla P,Monegal M, Seoana Y, Salas } \\
\text { K, Pedreny R. Escola Universitària } \\
\text { d'Infermeria. Universitat de Barcelona. } \\
\text { Barcelona }\end{array}$ \\
\hline $\begin{array}{l}\text { Full d'alta del pacient diabètic: la seva } \\
\text { utilitat com a instrument de relació amb } \\
\text { l'atenció primària }\end{array}$ & $\begin{array}{l}\text { Ruiz C,Benitez D, Campamá I, Lecumberri } \\
\text { C, Rueda P, Zapater R, Micaló T. Hospital } \\
\text { de Viladecans. ABS del Sector Gavà }\end{array}$ \\
\hline $\begin{array}{l}\text { Impacte d'un programa de garantia de } \\
\text { qualitat en l'atenció al diabètic tipus } 2\end{array}$ & $\begin{array}{l}\text { Benito B, Bassas J, Viladas L, Escolar } \\
\text { N, Ruiz C, Egido A. ABS Raval Sud. } \\
\text { Barcelona }\end{array}$ \\
\hline $\begin{array}{l}\text { Medi hospitalari: fomenta o inhibeix la } \\
\text { independència del pacient? }\end{array}$ & $\begin{array}{l}\text { Seoane Y, Bou N, Jiménez A, Monegal M, } \\
\text { Doménech E, Isla P. Barcelona }\end{array}$ \\
\hline $\begin{array}{l}\text { Diferències en la qualitat de l'atenció al } \\
\text { diabètic entre centres d'atenció primària } \\
\text { rurals i urbans }\end{array}$ & $\begin{array}{l}\text { Berengué M,Tomás P, Cano JF, Mata } \\
\text { M, Franch J, Méndez A. Grup GEDAPS. } \\
\text { Societat Catalana de Medicina Familiar i } \\
\text { Comunitària. Barcelona }\end{array}$ \\
\hline $\begin{array}{l}\text { Programa d'intervenció nutricional en } \\
\text { atenció primària adreçat a pacients amb } \\
\text { excés ponderal: Modificació d'hàbits } \\
\text { alimentaris, d'exercici físic i de reducció } \\
\text { ponderal }\end{array}$ & $\begin{array}{l}\text { Urbano P, Álvarez MA, García Pascual L, } \\
\text { Cano A, Valverde M, Esquius E, Moreno } \\
\text { F, Anglada J. Servei d'Endocrinologia } \\
\text { i Nutrició. Hospital Mútua Terrassa. } \\
\text { Terrassa }\end{array}$ \\
\hline
\end{tabular}


Valoració dels diabètics atesos en atenció primària

García MR, Hernández AR, Arnau T, Giner R,González S, Gorrindo C. ABS Camps Blancs. St. Boi de Llobregat

Formació bàsica en diabetis: una experiència universitària

Isla P, Doménech E, Icart T, Insa R, Queralt M, You C, Pedreny R. Escola Universitària d'Infermeria. Universitat de Barcelona. Barcelona

Millora contínua de l'atenció als pacients diabètics tipus 2

Ortega I, Mestre X, Gros T, Planas $R$, Rodríguez L, Vidal P.CAP Ronda Cerdanya. ABS Mataró-5. Mataró

Realitat sobre els coneixements en diabetis del personal d'infermeria

Millán M, García Pascual L, Valverde M, Urbano $P$, Cano S, Esquius E, Del Solar C. Servei d'Endocrinologia i Nutrició. Hospital Mútua Terrassa. Terrassa

Aprendre en grup, 3 anys d'experiència

Ribas E, Vila C, Solanas G, Martín D, Català M, Pardo C. ABS Manresa-4. DAP. Bages Bergadà Solsonés. Manresa

Diabetis i Autoanàlisi

Flores L, Fernández F, Martínez S, Carmona F, Toyos C, Levy I. Servei d'Endocrinologia i Nutrició. Servei d'Obstetrícia. Hospital Clínic i Universitari. Laboratori Lifescan. Barcelona

Educació Nutricional grup de pacients obesos-DM2

Yoldi G, Johnston S, Sanmartí A. Hospital Universitari Germans Trias i Pujol. Badalona

Diabetis de tipus 2: Qualitat assistencial en Atenció Primària

Tomás $\mathrm{P}$, Cano JF, Berenguer $\mathrm{M}$, Gimbert RM, Llussà J, Mundet $X$, Birulés $M, i$ GEDAPS, Societat Catalana de Medicina Familiar i Comunitària. Barcelona

\section{Congrés de l'Associació Catalana de Diabetis (any 1999)} (Comunicacions orals presentades a la Sessió d’Educació Diabetològica)

La vivència del diabètic: entre la salut aparent i la malaltia real
Millán M, Millán MD, Del Campo J, Antón S.

Hospital Mútua Terrassa. Facultat de Pedagogia UB. Barcelona 


\begin{tabular}{|c|c|}
\hline $\begin{array}{l}\text { Qualitat de vida en el debut de la } \\
\text { diabetis }\end{array}$ & $\begin{array}{l}\text { Insa R, Juanola MD, Boltaña A, } \\
\text { Fernández M. Servei d’Endocrinologia } \\
\text { CSUB. Bellvitge. Hospitalet de Llobregat } \\
\text { EUI. Hospital General Vall d'Hebrón. } \\
\text { Barcelona }\end{array}$ \\
\hline $\begin{array}{l}\text { No tanquem per reformes, seguim } \\
\text { treballant per la diabetis }\end{array}$ & $\begin{array}{l}\text { Rodríguez MD, Espluga A, Collado } \\
\text { M,Tomás M, Rivas L, Cabasés T. } 7 \text { ABS de } \\
\text { la DAP Baix Llobregat-Centre }\end{array}$ \\
\hline $\begin{array}{l}\text { L'actitud dels professionals de la salut en } \\
\text { relació amb la diabetis }\end{array}$ & $\begin{array}{l}\text { Figuerola D, Rojas I. Fundació Rosend } \\
\text { Carrasc i Formiguera. Barcelona }\end{array}$ \\
\hline $\begin{array}{l}\text { La motivació com a element essencial en } \\
\text { el procés de formació }\end{array}$ & $\begin{array}{l}\text { Urbano, Valverde M, Cano S, } \\
\text { Esquius E, Millán M, Antón S. Servei } \\
\text { d'Endocrinologia Hospital Mútua } \\
\text { Terrassa. Facultat de Pedagogia UB. } \\
\text { Barcelona }\end{array}$ \\
\hline $\begin{array}{l}\text { Plans de cures estandaritzats (PCE) en } \\
\text { diabetis }\end{array}$ & $\begin{array}{l}\text { Páramo C, Rodriguez B. ABS Drassanes. } \\
\text { Barcelona }\end{array}$ \\
\hline $\begin{array}{l}\text { Diagnóstico y tratamiento de las úlceras } \\
\text { neuropáticas }\end{array}$ & $\begin{array}{l}\text { Gaitán J. Servicio de Endocrinología y } \\
\text { Nutrición. Unidad de Podología. Hospital } \\
\text { de la Sta. Cruz y San Pablo de Barcelona }\end{array}$ \\
\hline $\begin{array}{l}\text { Aplicació d'un programa d'educació } \\
\text { bàsica en diabètics ingressats (PEBDI) }\end{array}$ & $\begin{array}{l}\text { Montfort C, Pizarro E, Ballestar } \\
\text { E, Claveria M,Palaudaries A. Unitat } \\
\text { d'Endocrinologia i Diabetis. Consorci } \\
\text { Sanitari de Mataró. Barcelona }\end{array}$ \\
\hline $\begin{array}{l}\text { Avaluació de la tècnica d'administració } \\
\text { d'insulina amb dispositius automàtics: } \\
\text { recarregades i rebutjables, en una } \\
\text { població DM2 d'edat mitjana avançada }\end{array}$ & $\begin{array}{l}\text { Martín E, Maria MA, Úbeda J, Pou } \\
\text { JM. Servei d’Endocrinologia i Nutrició. } \\
\text { Hospital de la Sta. Creu i St. Pau. } \\
\text { Universitat Autònoma de Barcelona }\end{array}$ \\
\hline
\end{tabular}

Font pròpia: Elaboració a partir dels programes dels congressos

Estudis rellevants, com el DCCT al 1993 o l'UKPDS al 1998, canvien les exigències dels control i donen un altre punt d'inflexió al desenvolupament de l'ET, ja que aquesta cobra més importància. L'evidència de la reducció de complicacions cròniques amb el tractament de múltiples dosi d'insulina i reduint l'HbA1c, en pacients amb DM1, i el concepte de memòria metabòlica, justifiquen el paper rellevant de la infermera en àrees com l'alimentació, l'exercici i l'ajust de pautes d'insulina. 
Però si bé s'encetaven els anys noranta amb una suposada consolidació de l'ET arreu de Catalunya, molta feina quedava per fer i molts van ser els canvis que es van produir cap a la segona dècada.

\subsubsection{Fusió de l'Associació Catalana d'Educadors en Diabetis amb la So- cietat Catalana de Diabetis}

Després d'obtenir l'opinió favorable dels associats d'ambdues societats sobre la proposta d'unificació que havia fet l'any anterior l'ACED, a l'abril del 1990, la Societat Catalana de Diabetis (SCD), representada únicament per professionals metges i presidida pel Dr. Daniel Figuerola, i l'ACED, presidida per la Sra. Judit Rodergas (infermera), van iniciar un procés d'unió de les dues societats, amb la convicció que el tractament de la persona amb DM és multidisciplinari i requereix d'una bona comunicació entre els diferents professionals que intervenen en el procés del tractament de la malaltia. Es va valorar que no tenia cap sentit mantenir dues societats que representaven la mateixa malaltia amb professionals diferents.

L'any 1991, durant el procés d'unificació de les dues societats, l'Asociación de Diabéticos Españoles (ADE), la Federación Española de Asociaciones de Educadores en Diabetes (FEAED) i la Sociedad Española de Diabetes (SED) proposen constituir un Consejo Superior de Diabetes, que pretén ostentar la representació oficial dels organismes associatius de caire estatal en la Federació Internacional de Diabetis. En aquest propòsit, tant la SCD com l'ACED acorden que la SED s'ha d'adaptar a la realitat política de l'Espanya autonòmica i justifiquen la negativa a aquesta proposta en el fet que el projecte d'unificació que proposen no respon al punt tercer dels següents arguments:

1. Aglutinar les associacions de persones amb diabetis i professionals de diferents àmbits és una iniciativa ambiciosa i altament positiva que està en la línia de models d'altres països més avançats.

2. Que a causa del fet del fort convenciment de la pertinença d'aquest objectiu, a Catalunya s'inicia el 1990 un procés d'unificació de la SCD i l'ACED que s'espera culminar el present any.

3. Que el procés necessari per arribar a aquest fi s'ha de desenvolupar tenint en compte tots els elements implicats, i això significa respectar l'opinió dels organismes implicats i integrar la realitat, social, cultural i política de l’Estat espanyol.

Finalment, el 26 d'octubre de 1991, en la VII Jornada de l'ACED, celebrada a Castelldefels, s'aproven en l'Assemblea General Extraordinària els Estatuts de la nova Societat i s'acorda que la dissolució de l'ACED es faria efectiva el dia 16 de maig de 1992.

Els dies 22 i 23 de maig de 1992 se celebrà a Terrassa el Congrés Constituent de l'Associació Catalana de Diabetis (ACD), com a resultat del llarg procés de fusió de les dues societats. És una societat pluridisciplinària, en què es pretén treballar per a temes d'interès i no per grups de professionals, i neix amb dues seccions bàsiques: 
- La secció d’Educació Diabetològica

- La secció de Diabetis Clínica

Un del problemes més grans de la fusió va ser la inclusió de les infermeres en una societat que depenia de l'Acadèmia de Ciències Mèdiques, ja que en aquell moment l'Acadèmia no acceptava professionals que no fossin llicenciats. Resoldre aquest problema va costar un seguit de negociacions per part de membres de la Junta de I'ACD.

La Junta de l'ACD sempre ha estat formada per 4 membres del col-lectiu no mèdic (infermeres, dietistes o podòlegs), que ocupen els càrrecs següents: vicepresident segon, tresorer i 2 vocals.

La fusió en una sola societat va ser un fet pioner en el nostre entorn i a la vegada modèlic, però els primers anys es respirava la sensació de pèrdua de rigor científic per part del col·lectiu de metges i de pèrdua de lideratge o protagonisme per part dels professionals de la infermeria; en general cap col-lectiu se sentia plenament integrat amb l'altre. De fet, molts dels professionals educadors que integraven l'ACED no es van incorporar a l'ACD, i això ho reflecteixen uns paràgrafs de les actes d'unes reunions de la Junta dels anys 1993 i 1994, que diuen textualment:

De moment no sembla que la nota informativa enviada per tal que s'incorporin a l'Acadèmia i a l'ACD tots els membres de l'antiga ACED hagi estat gaire efectiva.

Acta de la reunió de la Junta de l'ACD, del 26 d'octubre del 1993

La Sra. Carme Pérez es queixa de l'escassa incorporació a l'ACD del col·lectiu que abans integrava l'ACED.

Acta de l'Assemblea General Ordinària de l'Associació Catalana de Diabetis celebrada a Sitges, del 29 d'abril del 1994, en el si del III Congres de l'ACD

Des de l'ACD, durant la dècada dels noranta, es va continuar treballant per:

\section{a) La reivindicació del reconeixement de l'especialització en diabetis}

A mesura que l'ETD s'havia anat consolidant s'anava considerant oportú reivindicar un reconeixement oficial d'especialització en DM, tal com s'havia plantejat des de la constitució de l'ACED.

Això ja ho deien els primers estatuts de l'Associació d'Educadors. Es van fer cartes al Ministeri en què es demanava la infermera formada en diabetis i en educació terapèutica. Vam estar molt a prop d'aconseguir l'especialització.

\section{Metge endocrinòleg}


Però la figura de la infermera experta en DM, com a professional reconeguda en l'escala laboral de l'ICS amb perfil i responsabilitats definides, amb un lloc de treball i una retribució concrets, encara era un somni llunyà. Per tirar endavant el procés d'acreditació, l'any 1992, abans de la fusió de les dues societats, es va fer un estudi per conèixer l'opinió dels professionals, com a dada de suport en la lluita per la tan desitjada acreditació. Els resultats d'aquest estudi es van presentar al 1r Congrés de l'Associació Catalana de Diabetis, celebrat a Manresa el 1993 (Annex 17).

Es va crear una comissió de treball format per set infermeres, totes membres de l'ACED. El Consell Assessor va donar suport a la realització d'aquest sondeig i els objectius van ser:

1. Conèixer l'efecte i la implicació dels professionals en l'educació diabetològica. Per implicació s'entenia la percepció subjectiva del professionals sobre si feien o no educació (no es va pretendre mesurar la qualitat de les intervencions ni si eren adequades o no a les necessitats dels pacients).

2. Conèixer el grau d'implantació en els centres, és a dir, saber si als centres es preveu com una activitat real i factible, amb recursos especialment dedicats en termes d'espai físic, personal, temps de dedicació, etc.

3. Conèixer la distribució per nivells assistencials.

4. Conèixer qui educa prioritàriament. Es pretenia confirmar la impressió que es tenia, és a dir, que majoritàriament educaven les infermeres. Semblava important verificar aquest fet a I'hora de reivindicar la plaça d'educador.

5. Conèixer quina és la formació específica dels educadors. Com que no existia una formació ni una acreditació concretes per als educadors, es volia constatar quins mitjans de l'oferta actual en formació continuada havien utilitzat les persones interessades a formar-se com a tals.

Es van adreçar enquestes als Serveis d'Endocrinologia de tots els hospitals, tant de tercer nivell com comarcals on hi havia Servei d'Endocrinologia o un servei de Medicina Interna amb algun metge endocrinòleg integrat, a les Àrees Bàsiques de Salut (ABS) i als CAP, on hi havia consulta d'endocrinologia. També es van enviar enquestes als 100 professionals que havien participat com a alumnes en els quatre cursos d'educació sanitària aplicada a la DM (Curs de Perfeccionament en Educació Diabetològica). Els resultats van ser:

- El 97 \% consideraven que es feia educació, però no entraven en consideració sobre la qualitat.

- El $48 \%$ dels centres disposaven d'espai físic per fer educació.

- El $96 \%$ consideraven que era la infermera qui havia incorporat l'educació com una tasca habitual. 
- El 63,5 \% realitzaven programes estructurats; la resta, a demanda.

- Només un $30 \%$ utilitzava de forma habitual un sistema d'avaluació.

- El $67 \%$ dels professionals havien fet el Curs Bàsic de Diabetis i el de Perfeccionament.

Les conclusions més importants d'aquest estudi van ser que:

- L'educació diabetològica havia entrat de ple en els centres on s'atenia les persones amb DM.

- No tots els centres reconeixien tenir endegat un programa estructurat.

- Es constatava una falta de treball en equip en les activitats educatives.

- La formació i l'acreditació de l'educador-expert en DM, així com la seva integració, eren cada cop una necessitat més prioritària.

Els mateixos autors consideraven decebedors els resultats a l'hora de justificar la importància de l'educació, ja que no es podien mostrar dades dels resultats dels programes o de les activitats educatives per manca d'avaluació.

Jo crec que en aquell moment ja vam veure que més o menys hi havia gent que feia coses, no d'una manera sistematitzada a tot arreu, però no es feia avaluació, i això és clar.

\section{Metge endocrinòleg}

El projecte d'acreditació de la infermera experta en DM no va progressar i es va deixar perquè la treballés la Junta de la nova Associació, constituïda el 1992, com a resultat de la fusió entre I'ACED i la SCD. Era innegable que l'ACD havia de continuar treballant per aconseguir l'acreditació dels educadors. En l'article II dels nous estatuts s'hi fa referència:

Contribuir al millorament científic dels seus afiliats mitjançant la promoció de cursos especialitzats per a Educadors en Diabetis i mecanismes d'educació continuada, facilitant a la Sanitat Pública i exigint-li a la vegada mecanismes de progressiva acreditació d'aquesta tasca, dedicant a la mateixa els recursos econòmics necessaris.

I durant els anys que van seguir a la fusió, aquest va ser un tema que sortia a les assemblees anuals, però no es va resoldre mai. A tall d'exemple: 
La Sra. Rodergas creu que seria necessari saber com es poden crear places d'educador en diabetis i com tipificar-les.

a la qual se li respon que:

Seria necessari el plantejament a nivell nacional de les societats implicades en el reconeixement de l'especialitat.

Acta de la reunió de l'ACD, del 21 d'abril de 1993

A continuació es mostra un paràgraf d'una acta de la Junta de l'ACD del 1999, on encara se seguia discutint el mateix problema de l'acreditació:

(...) com a ACD, s'hauria de promoure que el sistema reconegués la necessitat de l'Educació Diabetològica. El Dr. Pou comenta que s"hauria de pressionar la Generalitat perquè no ocupin els llocs de treball persones no aptes. El Dr. Leiva explica que la FEND ha treballat per crear una diplomatura en Educació Diabetològica, implicant la Universitat d'Uppsala (Southhampton) i la UAB. A més, hi ha un acord entre la Universitat de Girona, la de Barcelona i l'Autònoma de Barcelona per crear una llicenciatura d'Infermeria. Si altres universitats del país adopten aquest esquema, es podria arribar a tenir una diplomatura de "X» crèdits en Educació Diabetològica. La Sra. Imma Gallach comenta que en una reunió del Consell Assessor sobre la Diabetis es va destacar que justament no hi ha cap marc legal per reconèixer actualment els educadors en diabetis. La Dra. Sanmartí opina que no se li pot demanar al Consell Assessor de la Diabetis que solucioni tots els problemes, i comenta que des de l'ACD potser s'hauria de ser més reivindicatiu. La Sra. Rodergas comenta que el tema és molt més complex del que en principi pugui semblar.

Acta de l'Assemblea General Ordinària de l'ACD, del 16 d'abril de 1999, a Barcelona, en el si del V Congrés de l'Associació Catalana de Diabetis

Cal destacar que únicament es va realitzar a la Universitat Autònoma de Barcelona un curs de la FEND, I'anomenat Programa ENDCUP, i no ha estat mai reconegut de forma oficial.

\section{b) En la formació dels educadors}

En l'acta de la reunió de la Junta Directiva de l'ACD del 3 de juliol del 1996 es proposa formar una comissió d'educadores per crear un curs que doni una acreditació d'educador reconegut per I'OMS. El setembre d'aquell mateix any es va proposar la realització d'un curs de postgrau per al curs acadèmic 1997-1998, que havia de ser aprovat per la universitat que el fes. Finalment, es va aprovar la realització d'un curs de postgrau de títol propi a la Universitat de Barcelona, coordinat per la Dra. Pilar Isla. 
Independentment de l'intent d'acreditació oficial, un dels objectius de l'ACD era la formació i el reciclatge dels educadors en diabetis per mitjà de tallers i simposis específics sobre peu diabètic, alimentació, exercici, embaràs o aspectes metodològics sobre la relació educativa. Cal destacar que el 1995, per primera vegada, I'ACD decideix concedir tres beques de 200.000 pessetes a socis amb experiència en el camp de l'educació diabetològica per assistir als cursos impartits pel prof. Assal a Grimentz (Suïssa).

\section{c) En la recerca sobre l'educació terapèutica}

Gràcies a la bonança econòmica de la nova Associació, es va incrementar l'import del Premi d'Educació Sanitària Aplicada a la Diabetis de l'any 1994 a 250.000 pessetes. Aquest intent d'incentivar els professionals educadors envers la recerca no va reeixir, perquè a la reunió de la Junta del 1994 es va plantejar la poca participació dels educadors a l'hora d'optar al premi, ja que s'havia mantingut de l'anterior ACDE.

Només s'ha presentat un treball i encara que és d'alta qualitat, la quasi nul·la participació diu molt poc en favor dels professionals dedicats a aquests aspectes de l'assistència diabetològica.

Acta de l'Assemblea General Ordinària de l'Associació Catalana de Diabetis celebrada a Sitges, el 29 d'abril de 1994, en el si del III Congrés de I'ACD

Un fet rellevant i que va passar bastant desapercebut va ser un estudi impulsat per l'ACD el 2003, amb el suport del Consell Assessor sobre la Diabetis a Catalunya amb l'objectiu de conèixer la qualitat i la quantitat d'educació diabetològica que rebien a Catalunya tots els pacients amb diabetis. Es van disenyar unes enquestes que es van enviar tant a l'AP com a l'AE. La taxa de resposta tant a l'AP com a l'AE va ser molt baixa (39\%) i les principals conclusions d'aquest estudi van ser que l'educació grupal estava poc implementada en ambdós àmbits i que la qualitat de l'educació mesurada pel temps que s'hi dedicava i els temes que es tractaven havia de millorar (Annex 18).

A diferència d'altres societats científiques, l'ACD no tenia cap revista científica pròpia i a causa de l'expansió d'eines digitals i de l'impacte que ja tenia Internet en el món científic, l'any 2003 l'ACD impulsa un butlletí digital al que anomenaren Diabetis Avui, que encara es manté en l'actualitat. En aquest butlletí hi col·laboren, amb la publicació d'articles rellevants, professionals de les diferents disciplines: infermeres expertes en ET, metges, psicòlegs, podòlegs i dietistes, entre d'altres. 


\subsubsection{Les associacions de pacients. Constitució de l'Associació de Diabètics de Catalunya}

El 1992 es va crear l'Associació de Diabètics de Catalunya (ADC), que neix de la fusió de nou associacions de diabètics de tot Catalunya. Cadascuna d'elles formava part de la Federació Catalana d'Associacions de Diabètics (FECADI) i ja havia cobert una etapa de sensibilització davant dels propis afectats i de l'opinió pública.

L'ADC actua a través de delegacions implantades per tot Catalunya i cadascuna fa una sèrie d'activitats a la seva zona d'acord amb els socis que la integren, segons les seves necessitats i disponibilitats. Els serveis que ofereix actualment l'Associació són:

1. Assessoria dietètica.

2. Assessoria jurídica.

3. Enviament de revistes: la revista Diabetes FEDE (editada per la Federación de Diabéticos Españoles).

4. Carnet de soci (Carnet $A C D)$ : ofereix avantatges econòmics en més de 70 comerços o empreses de serveis.

5. Servei de cangur per a nens amb DM.

6. En algunes delegacions ofereixen servei de psicologia, d'educació terapèutica, assessoria mèdica, venda de material diabetològic $\mathrm{i}$ aliments aptes per a persones amb DM.

Cal destacar que l'ADC, a través del seu president, sempre ha tingut una representació permanent en el Consell Assessor sobre la Diabetis a Catalunya, per tal de donar visibilitat i solució als problemes dels pacients.

\subsubsection{Canvi del paradigma inicial}

Tot i que la reforma de l'APS a Espanya es va produir el 1984, i malgrat l'aplicació de la Ley General de Sanidad, al 1986, no va ser fins ben entrats els noranta que la figura de l'educador en DM als CAP va ser assumida per les infermeres generals, a les quals es va delegar la funció del control i seguiment de les malalties cròniques, inclosa la DM. S'assumeix que només amb la formació de la carrera d'infermeria es tenen els coneixements suficients tant per al seguiment clínic com per proporcionar educació de qualitat en DM. Aquest fet, fruit dels canvis polítics i d'estructura sanitària, provoca moltes desigualtats en la formació dels professionals, que poden repercutir en l'atenció dels pacients. En aquest apartat es descriuran els canvis que s'han produït des de la primeria dels anys noranta fins a l'actualitat 
Diferents opinions dels entrevistats intenten argumentar per què es produeix aquesta pèrdua del valor de la infermera educadora en DM:

\section{a) Canvi polític i sanitari}

Aproximadament al 1992, un cop acabada la reforma de l'AP, es produeix un canvi del concepte d'atenció lligat també a canvis polítics i sanitaris. La part humanística, tan valorada, es va començar a desacreditar en favor de tot el que era observable i mesurable. Es prioritza el nombre de visites en detriment de la qualitat i de la possibilitat d'aplicar els programes d'educació, i la visió que es té del malalt és la d'un «client».

La direcció va canviar i llavors el que era important no era el que es feia a la consulta, sinó el nombre de vegades que el veies. Van voler prostituir una mica el que era l'educació. El que la infermera havia de fer eren vint visites, no sé, llavors va començar a desvirtuar-se. Va ser quan es va començar a parlar del fet que el malalt era un client.

\section{Metge endocrinòleg}

A través d'aquest canvi polític i sanitari es produeix una pèrdua del suport i la potenciació de l'ET en el nivell d'especialitat a canvi d'una aposta ferma per l'AP, ja que es va considerar que els professionals d'infermeria, amb el seu currículum formatiu de Diplomat, ja tenien els coneixements suficients per tractar qualsevol patologia crònica, i que no era necessària la figura d'un professional més expert per fer de suport en alguna àrea determinada, com ara la DM. Així doncs, en aquell moment, la figura de la infermera referent en DM que existia en la majoria de centres d'AP anava desapareixent. Tot i que la idea no va progressar, en les direccions d'alguns hospitals també es qüestionava la continuïtat dels programes educatius d'acord amb la idea de que l'AP era l'única responsable de l'educació dels pacients.

Me decían que la educación era cuestión de primaria, que no era de un hospital de tercer nivel, y esta idea estaba muy metida en la cabeza de los directores de entonces.

Dra. en Infermeria. Infermera experta en diabetis

La reforma de la atención primaria trajo muchas cosas positivas, pero una negativa en cuanto a la diabetes, y es que desaparecieron las unidades de educación en los centros de especialidades y aquellas enfermeras formadas desaparecieron de un plumazo.

Dra. en Infermeria. Infermera experta en diabetis. 
Els programes d'atenció a la DM que duien a terme les diferents àrees sanitàries també es van anar suprimint. El programa d'atenció al diabètic de l'Àrea de Gestió 7, Centre de I'ICS, de la Generalitat de Catalunya, va durar del 1988 al 1994. Aquest programa va motivar la implementació de programes d'educació també per a pacients, va fomentar la investigació en el camp de la DM en diferents centres de l'Àrea i va permetre iniciar un projecte d'implantació de les Unitats de Diabetis, Endocrinologia i Nutrició (UDEN) concretament a l’Hospital Mútua Terrassa i al de Granollers, dotades de personal com endocrinòlegs, infermeres educadores en DM, podòleg i nutricionista. L'any 1992 no s'havien assolit una gran part dels objectius plantejats en el programa, entre els quals el nombre d'infermeres educadores. El 1994 es va aturar la continuïtat del programa.

Aquest projecte de les UDEN no va progressar. El 1995 en el document de la cartera de servei no s'accepta la figura de l'educador en DM, i el mateix Dr. Gonçal Lloveras afirma durant I'Assemblea General Ordinària del III Congrés de l'ACD que les UDEN no s'han pogut implementar perquè queden incorporades dins d'una reforma més àmplia que inclou l'AP (acta de I’Assemblea General Ordinària de I’Associació Catalana de Diabetis. Barcelona 25 maig 1995. III Congrés de l'ACD).

Els endocrinòlegs de l'AP van quedar sense professionals infermers formats en educació i es van trobar immersos en una situació laboral insostenible, donada la incapacitat de poder assumir l'educació dels pacients i la gran massificació de pacients a les consultes.

El Dr. Mesa informa que professionals que treballen a Centres d'Assistència Primària han manifestat les precàries condicions de treball en les quals es troben. Després d'una reunió amb la presidenta de la Societat Catalana d'Endocrinologia, Dra. Sanmartí, aquesta suggereix constituir un grup d'estudi de l'assistència a Catalunya integrat per metges directament implicats en l'Assistència Primària, metges no implicats directament, educadors i dietistes. La primera tasca d'aquest grup seria fer un estudi de la situació real de l'assistència a Catalunya per poder reclamar als responsables tant d'institucions privades com públiques mesures per millorar l'actual situació. El Dr. Conget manifesta que potser, abans de fer les reivindicacions oportunes, s'hauria de redactar una carta per demanar a I'ICS els seus plans per a l'organització de l'assistència a Catalunya... El Dr. Mesa manifesta que I'ICS vol finalitzar la transferència l'any 2002 establint que l'AE es realitzarà en els hospitals i que la jerarquitzada en els CAP i que l'estratègia que està seguint és reduir el nombre d'especialistes. i a més a més s'estan eliminant les places d'educadors en diabetis en els Centres d'Assistència Primària... La major part d'especialistes són interins, per la qual cosa no tenen força per negociar.

Acta de la Junta Directiva de l'ACD, del 5 de febrer de 2001, Acadèmia de Ciències Mèdiques 
Anys més tard, algun estudi mostra la repercussió de la pèrdua d'infermeria experta en DM als CAP:

Tras suprimir la ED especializada, el porcentaje de pacientes con un control metabólico muy bueno, y, por tanto, con menor riesgo microvascular y macrovascular, quedó reducido casi a la mitad ${ }^{270}$.

La forma en què en l'àmbit polític l'ET va anar perdent suport es reflecteix també en els diferents plans de salut que s'han elaborat des de l'any 1991 (Taula 3). Com es pot observar, I'ICS, des del marc del tractament de les malalties cròniques com la DM, i tenint en compte la importància de l'autoresponsabilització del pacient i el foment de l'autocura, ja no entén els programes d'ET com una eina per a aquest fi, i ha obviat del tot la importància que han tingut i tenen els programes d'ET, així com la formació dels professionals, i s'ha acollit a una nova estratègia consistent en el programa «Pacient Expert». Aquest programa no té en compte la formació generalitzada dels professionals que tracten la DM, que a l'AP són la majoria del personal d'infermeria, sinó que promou una formació adreçada només als professionals que es faran càrrec dels programes a cada centre $i$ als pacients escollits per representar el «pacient expert». En el darrer Pla de Salut de Catalunya, només es considera com a eina educativa el programa «Pacient Expert Catalunya».

Segons les paraules de la directora del programa «Pacient Expert Catalunya», aquest no és un programa d'educació sanitària, sinó un programa d'acció comunitària on els professionals només participen en la formació del pacient expert i no pas en la del grup de pacients. Assegura que aquest programa se centra en la conscienciació del pacient sobre el seu problema de salut

Quan nosaltres posem el programa en marxa, jo dic dos coses molt importants. Una, que no estàvem fent un programa d'educació sanitària, perquè educar, educa el professional. El pacient no és ni un professor ni un substitut del metge ni de la infermera, però és el que conduirà el grup. Dos, és un programa d'educació comunitària, és a dir, posem una persona d'una zona, d'un EAP, on hi ha més persones que tenen aquest problema i que es troben a l'escola, al passeig a comprar el pa. Doncs els ajuntem fora del centre de salut, en seleccionem un, el que té més criteris o capacitat d'interrelació, d'aprenentatge... perquè els professionals el formaran, no participen activament i només fan d'observadors.

Sra. Xon González. Infermera

Se li pregunta a la Sra. Xon González si el programa «Pacient Expert Catalunya» se centra només en la conscienciació de la persona sobre el seu problema de salut, i respon: 
Sí, i per tant, vol fomentar l'autocura. La malaltia és d'ell. Un cop la persona pren consciència del que té, comença a canviar els hàbits, els estils de vida. Veuen la importància que té fer-ho i veuen un benefici, i és això el que els permetrà mantenir aquests canvis al llarg del temps.

\section{Sra. Xon González. Infermera}

També se li comenta a la Sra. Xon González que en l'educació grupal ja sempre s'ha procurat utilitzar la figura d'un pacient més implicat, motivat i amb més coneixement, o que ha viscut directament un problema, per afavorir la relació entre iguals i la conscienciació del problema. On seria, doncs, la diferència? I ella contesta:

Aquí la diferència està en el fet que el professional no pot intervenir i que el grup el porta el pacient.

\section{Sra. Xon González. Infermera}

Taula 3: Importància que dona el Pla de Salut de Catalunya a l'Educació Terapèutica en diabetis

\begin{tabular}{|c|c|}
\hline $\begin{array}{l}\text { Document marc per } \\
\text { a l'elaboració del Pla } \\
\text { de Salut } 1991\end{array}$ & $\begin{array}{l}\text { Fixa els objectius de salut i de disminució del risc a mig i llarg termini } \\
\text { seguint les recomanacions de l'oficina regional europea de l'OMS en } \\
\text { l'estratègia «Salut per a tothom a l'any } 2000 \text { ». No parla de l'educació } \\
\text { diabetològica, sinó de l'educació sanitària en l'àmbit d'AP en aspectes } \\
\text { de prevenció sobre factors de risc com la hipercolesterolèmia, la HTA, } \\
\text { l'obesitat o el sedentarisme. }\end{array}$ \\
\hline $\begin{array}{l}\text { Pla de Salut 1993- } \\
1995\end{array}$ & $\begin{array}{l}\text { Es basa en els objectius de la Declaració de Saint Vincent. } \\
\text { «- L'educació diabetològica i l'ensinistrament dels pacients en } \\
\text { tècniques d'autoanàlisi i autocura permeten reduir la incidència de les } \\
\text { complicacions, i un cop aconseguit el control glicèmic, el tractament i el } \\
\text { control dels factors de risc cardiovascular han demostrat ser tan efectius } \\
\text { com en la població general. } \\
\text { - L'educació diabetològica, el control dels factors de risc cardiovasculars, } \\
\text { el control metabòlic i el diagnòstic precoç de les complicacions } \\
\text { cròniques han demostrat la seva capacitat de retardar-ne l'aparició i } \\
\text { millorar-ne el pronòstic.» } \\
\text { Entre les línees d'actuació, inclou la formació dels professionals. } \\
\text { Quant als objectius operacionals de les regions sanitàries, el punt A } 155 \\
\text { diu: «Tots els diabètics coneguts han de rebre educació diabetològica } \\
\text { adaptada al grau d'evolució de la malaltia». }\end{array}$ \\
\hline $\begin{array}{l}\text { Pla de Salut 1996- } \\
1998\end{array}$ & $\begin{array}{l}\text { Es basa en els objectius de la Declaració de Saint Vincent. } \\
\text { Una de les tres intervencions prioritàries és la «promoció dels } \\
\text { programes de formació i educació diabetològica per als diabètics de } \\
\text { totes les edats, els seus familiars i també per as equips sanitaris». }\end{array}$ \\
\hline $\begin{array}{l}\text { Pla de Salut 1999- } \\
2001\end{array}$ & $\begin{array}{l}\text { Es mantenen les intervencions i accions proposades en el Pla de Salut } \\
\text { 1996-1998, que en la diabetis se centren fonamentalment en la detecció, } \\
\text { el tractament i el control de la malaltia i les seves complicacions, } \\
\text { l'educació sanitària de la població i la sensibilització dels professionals. }\end{array}$ \\
\hline
\end{tabular}




\begin{tabular}{|c|c|}
\hline \multirow{3}{*}{$\begin{array}{l}\text { Pla de Salut 2002- } \\
2005\end{array}$} & $\begin{array}{l}\text { Justifica les intervencions adreçades al control intensificat per reduir les } \\
\text { complicacions influenciades pels dos grans estudis, el DDCT i l'UKPDS. } \\
\text { «L'educació diabetològica en l'atenció al peu diabètic i l'exploració } \\
\text { periòdica en persones diabètiques amb risc elevat de lesions als peus } \\
\text { comporta una reducció de la seva aparició i de la necessitat de realitzar } \\
\text { amputacions proximals. Existeixen evidències limitades, a partir d'un } \\
\text { assaig clínic no aleatori, que l'educació dels pacients després d'haver } \\
\text { presentat una complicació aguda redueix el risc de recurrència de les } \\
\text { ulceracions i d'amputacions majors». }\end{array}$ \\
\hline & $\begin{array}{l}\text { Les activitats proposades per a la diabetis mellitus fins al } 2010 \text { es } \\
\text { basaran en la detecció, el tractament i el control de la malaltia i de } \\
\text { les seves complicacions en l'àmbit de l'atenció primària, mitjançant } \\
\text { l'aplicació dels criteris comuns mínims, la promoció de programes } \\
\text { d'educació diabetològica i d'autocura per als afectats i la conscienciació } \\
\text { de la població general i dels professionals sobre les possibilitats } \\
\text { preventives de la diabetis. }\end{array}$ \\
\hline & $\begin{array}{l}\text { Entre les intervencions prioritàries: s'elaboraran i distribuiran materials i } \\
\text { guies d'educació sanitària de suport a l'educació diabetològica per tal de } \\
\text { promoure l'autocura dels afectats. }\end{array}$ \\
\hline $\begin{array}{l}\text { Pla de Salut a } \\
\text { l'Horitzó } 2010\end{array}$ & $\begin{array}{l}\text { «'’educació sanitària i l'exploració periòdica de persones amb diabetis } \\
\text { comporten una reducció de l'aparició de lesions als peus, així com } \\
\text { de la necessitat de realitzar amputacions proximals. La detecció i el } \\
\text { tractament precoç de la retinopatia i la nefropatia eviten la progressió a } \\
\text { fases més avançades d'aquestes malalties». }\end{array}$ \\
\hline \multirow{3}{*}{$\begin{array}{l}\text { Pla de Salut 2011- } \\
2015\end{array}$} & $\begin{array}{l}\text { Projecte 2.3. Potenciar l'autoresponsabilització dels pacients i dels } \\
\text { cuidadors amb la seva salut i fomentar l'autocura (pàg. 93). }\end{array}$ \\
\hline & $\begin{array}{l}\text { L’objectiu del projecte és capacitar els pacients en l’autogestió de la } \\
\text { malaltia, }\end{array}$ \\
\hline & $\begin{array}{l}\text { Han tingut èxit diverses experiències d'intercanvi de coneixements entre } \\
\text { pacients com a mitjà per a l'expansió de l'autogestió sobre la malaltia, } \\
\text { com és el cas del programa anomenat «Pacient Expert Catalunya». En } \\
\text { aquest sentit, una línia central en el marc del projecte serà l'extensió } \\
\text { d'aquest programa, específic per a cada malaltia prioritzada, i d'acord } \\
\text { amb el disseny del procés clínic }\end{array}$ \\
\hline \multirow{2}{*}{$\begin{array}{l}\text { Pla de Salut 2016- } \\
2020\end{array}$} & $\begin{array}{l}\text { El Pla de salut de Catalunya } 2016-2020 \text { promou l'atenció centrada en la } \\
\text { persona i les activitat per l'autoresponsabilització dels pacients vers la } \\
\text { seva malaltia o prevenció a través de la continuitat del programa Pacient } \\
\text { Expert Catalunya. }\end{array}$ \\
\hline & $\begin{array}{l}\text { «El Pla de salut de Catalunya 2016-2020 especifica un grup de prioritats } \\
\text { de salut i reforça les àrees d'intervenció prioritàries del període 2011- } \\
2015 \text {, i les amplia per tal d'aconseguir millores en àmbits com ara: les } \\
\text { malalties transmissibles, inclosa la vigilància i el control comunitaris, les } \\
\text { malalties minoritàries, l'atenció primària i salut comunitària, així com la } \\
\text { salut infantil i juvenil, especialment pel que fa a la salut mental». }\end{array}$ \\
\hline
\end{tabular}

Font: Pròpia a partir de la revisió dels plans de salut 


\section{b) La formació en diabetis i educació terapèutica dels professionals deixa de ser prioritària per a l'Administració sanitària}

A la segona meitat dels anys vuitanta, l'IES va deixar d'oferir la formació dels professionals. No hi ha una opinió unànime del motiu pel qual es va desvincular d'aquesta formació en DM i metodologia de l'educació. Les opinions més coincidents són:

1. Es va considerar que ja s'havia format prou gent per distribuir-se tant en els centres d'especialitats com en I'AP, i que no en calia més.

2. En el moment que va sorgir la Fundació per a la Formació Contínua de les Empreses (FORCEM), I'IES va considerar que ja no havia d'omplir el buit de la formació contínua dels professionals.

3. L'IES va considerar que no li interessava fer cursos tan llargs (60 hores o més).

4. L'IES i el Consell Assessor van decidir retallar aquesta formació vist el nombre de persones formades que després no van seguir el camí de l'educació diabetològica.

La formació en DM dels professionals va anar adquirint un caire voluntari. Els cursos de postgrau i educació contínua en DM són oferts per universitats, associacions de DM i la indústria farmacèutica, la qual esdevé el principal recurs per a la formació en DM, i a la vegada els mateixos educadors són el principal recurs docent que té la indústria. Aquests cursos poden estar acreditats per les diferents autoritats o societats científiques, però aquestes acreditacions encara no aporten cap valor afegit o diferencial en el lloc de treball.

Hay muchos contextos en los que uno se puede formar, pero creo que ha quedado un vacío en el que había la suficiente potencia y la suficiente experiencia como para que esto hubiera quedado institucionalizado, es decir, enseñanza reglada. (...) Creo que uno de los fallos, para mí, es que quizá mucha formación ha sido llevada a cabo por muchos laboratorios. Entonces la formación reglada posibilitaría que las personas que tuvieran interés por el tema pudiesen optar a eso.

Dra. en Infermeria. Infermera experta en diabetis

Ha quedat tot en la voluntarietat de la gent que hi treballa i no hi ha hagut una formació específica. No tothom té la mateixa formació ni la mateixa experiència professional, i encara que les tinguin no li donen punts perquè li donin una plaça d'aquestes característiques.

Infermera experta en diabetis 
Només en alguns hospitals o centres d'especialitats hi ha encara professionals dedicats de forma més exclusiva a l'ETD. Cal destacar l'equip d'infermeres de l'Hospital Clínic de Barcelona com el que té més impacte avui dia quant a projecció externa, tant en l'àmbit de Catalunya com d'Espanya i d'Europa.

\section{c) La infermera polivalent}

Aquest concepte va lligat a la idea que la infermera serveix per a qualsevol tasca, no es té en compte la formació específica ni l'expertesa. Amb la reforma sanitària es produeix un gran projecte de potenciar l'AP en front de l'assistència hospitalària. En l'article primer del Decret 84/1985, de 21 de març, es considera la primera com el «primer graó d'accés al ciutadà a l'assistència sanitària, integra l'atenció preventiva, curativa, rehabilitadora i la promoció de la salut de la comunitat».

Dins d'aquest projecte s'aposta per la infermera polivalent en front de la infermera especialitzada. Per tant, això va ser una decisió de política sanitària d'aquell moment.

\section{Metge endocrinòleg}

Tot i que en els hospitals aquesta consideració també ha estat molt vinculada a la política de substitucions o de mobilitat del personal, en la majoria s'ha aconseguit mantenir aquesta figura a les Unitats d’Endocrinologia, Nutrició i Diabetis.

\footnotetext{
Esta idea que había incluso en el hospital de que la enfermera es polivalente es una falsedad, porque la sanidad es muy compleja, pero si trabajas atendiendo a personas con diabetes, lo primero que tienes que saber es mucha diabetes y mucha nutrición y pedagogía y comunicación, tienes que saber investigar, no puedes ser generalista.
}

Dra. en Infermeria. Infermera experta en diabetis

Als hospitals no els convé infermeres expertes, els convé més la polivalent.

\section{Metge endocrinòleg}

Hi va haver un canvi en tota la reestructuració sanitària i en els Centres d'Atenció Primària en què hi havia aquestes infermeres mes especialitzades, i es va passar al fet que la infermera era polivalent, de manera que es va perdre aquella especificitat en el que seria l'educació en diabetis.

Infermera experta en diabetis 
Falta que els professionals estiguin més preparats, perquè avui dia les direccions d'infermeria pensen que la infermera és polivalent.

Infermera experta en diabetis

\section{d) Pèrdua del compromís dels metges amb l'educació}

Amb el pas del temps molts dels professionals que van liderar l'educació, la gran majoria metges, o que van lluitar per la seva implementació, han anat perdent la implicació a mesura que transferien aquest lideratge a altres professionals (infermeria). En paral.lel, aquesta pèrdua d'implicació ha repercutit a no reivindicar l'educació en les noves generacions de professionals mèdics, en aquest cas.

Hi ha hagut una cosa que des del meu punt de vista és negativa, que és que ha desaparegut el metge com a educador, entendre l'educació com una part del tractament, i ho ha deixat només en mans d'altres professionals, ha perdut la implicació.

\section{Metge endocrinòleg}

Les educadores en diabetis han sigut molt i molt útils, però com que molts endocrins que han sigut desprès cap de servei d'Endocrinologia no ho han valorat gaire, han valorat més altres coses: a part de la investigació, han valorat més l'assistència, els controls que es fan etc.; doncs això no ha tingut la repercussió que un esperava i va canviar completament el panorama.

\section{Metge endocrinòleg}

Hi ha equips que han lluitat per mantenir les educadores a costa d'un metge més i hi ha equips que volen un metge i no els importa una educadora. En la meva opinió, aquesta part ha fet mal als equips de diabetis. Hi ha qui prescriu educació de la mateixa manera que prescriu insulina i se'n desentenen; això va malament perquè no s'ha promocionat, a vegades no s'introdueixen les infermeres dins l'equip.

\section{Metge endocrinòleg}

Dins el col-lectiu mèdic, els residents no tenien el mateix grau de compromís.

\section{Infermera experta en diabetis}


El metge s'ha implicat relativament poc, ha delegat, ha donat poder i ha perdut la por al poder de la infermeria que es dedica a l'educació.

\section{Metge endocrinòleg}

\section{e) Manca d'iniciativa dels que creuen en l'educació, de lideratge i de metodologia de treball del col·lectiu d'infermeria}

Segons l'opinió d'alguns professionals, les infermeres no han tingut la capacitat de lluitar pel manteniment d'aquesta figura ni en l'àmbit institucional ni en el polític per diferents motius: uns creuen que no s'ha sabut donar un cos científic a l'educació, d'altres creuen que no s'han sentit ajudats ni pels companys ni per les direccions d'infermeria.

Aquells que en el seu moment ho havíem de defensar ens vam dispersar i diluir una mica. Potser vam desenvolupar poc la metodologia dels resultats, de l’observació, dels objectius qualitatius.

Infermera experta en diabetis

A l'hora de fer alguna cosa estructurada, no ho vaig fer i no vaig tenir el suport d'altres companys.

Infermera experta en diabetis

Ha faltat iniciativa per part dels que creuen en l'educació terapèutica, hem estat molt parats durant un temps. Metge endocrinòleg

\section{f) El paper i les competències de les infermeres educadores en DM genera conflicte amb la infermeria de l'AP}

Completada la implantació de la reforma de l'AP, alguns educadors van integrar-se com a infermeres generalistes als CAP, i altres van continuar com a educadors als CAP II o d'especialitats formant equip amb l'endocrinòleg. Això va començar a generar un conflicte a l'hora de definir el paper i les competències de l'educador, ja que també s'autoanomenen educadores les infermeres de l'AP, atès que tenen la responsabilitat d'atendre i educar els pacients amb DM encara que no tinguin la formació necessària. El Dr. Bernardo Costa, que va iniciar els primers programes d'ET a Tarragona, i que des del 1994 és metge d'AP a Reus, dona la seva visió respecte al conflicte que podia generar l'acreditació en col·lectius de diferents nivells d'atenció. 
La figura del educador, el propio educador contribuyó un poco a diluirla. Se llegó a un momento en que pareció dársele más importancia al reconocimiento de la acreditación como tal que al hecho en sí mismo al que estaba llamado el educador, que era educar. Se planteó para la universidad una situación incómoda, porque vendría a ser como una situación de superenfermería. Esto se iba a sectorizar en un grupo elegido de personas que habían tenido acceso a esta formación para formar habitualmente en consultas especializadas de endocrinología.

Esto generó un movimiento de las enfermeras de Atención Primaria, porque claro, por el solo hecho de no estar en una consulta especializada, ¿ por qué no podían ser también educadoras en diabetes y reconocidas?

\section{Dr. Bernardo Costa}

\section{g) Política de mobilitat del personal en dels centres}

La falta d'acreditació formativa, lligada a la falta de reconeixement per part de les direccions dels centres, comporta que, en general, els criteris de mobilitat del personal en els centres de treball s'estableixin en base a l'antiguitat i no pas a l'experiència professional o a una formació específica.

A nosaltres ens va passar que per dos dies més d'antiguitat van treure la persona que nosaltres havíem format $i$ en van posar una altra que no en sabia res.

\section{Metge endocrinòleg}

\subsubsection{Visió actual de l'educació terapèutica en diabetis per part dels professionals implicats}

Els professionals implicats en l'ET dels pacients amb DM opinen que la infermera educadora en DM degudament formada és una peça clau en el tractament de la malaltia, i que ho seguirà sent. El principal problema continua sent la manca de reconeixement professional d'aquesta feina.

Les idees globals que es poden extreure de les entrevistes realitzades entorn de la situació actual són les següents:

- Hi ha una ignorància transversal sobre la complexitat de la malaltia i del seu tractament, que es reflecteix en diferents nivells:

- Administració sanitària: Es preocupa perquè el pacient crònic sigui atès en unitats específiques o en I'AP. S'han establert criteris sobre quin ha de ser l'àmbit d'atenció de les patologies cròniques. En el cas de la DM2, se'n delega completament l'atenció a l'AP, però es no té en compte quina és la formació dels professionals als quals es delega aquesta atenció. 
Los gestores creen que la educación es enseñar cómo se pone la insulina o cómo hacer una dieta, y que esto lo puede hacer cualquiera.

\section{Metge endocrinòleg}

Yo sigo pensando que todavía hoy no se ha comprendido lo que es la cronicidad. Que está todo preparado para la medicina aguda, desde las programaciones hasta todo y que resulta difícil en nuestro sistema tener presente todo lo que implica la cronicidad.

\section{Infermera experta en diabetis}

- Direccions dels centres: Una bona formació en gestió no garanteix una formació infermera en ET. Per tant, difícilment la direcció podrà exigir als professionals d'infermeria d'un CAP o d'una Unitat de Diabetis d'un hospital que apliquin programes d'ET de qualitat si manca el coneixement bàsic del que significa educar. El que succeeix és que les direccions es limiten a fer complir els objectius que marca el Servei Català de la Salut, i si l'objectiu és l'educació dels pacients crònics, aquesta es fa de la manera que cada professional entén.

S'han fet grups d'educació en certs moments, perquè ha interessat a la direcció, amb professionals que no en tenien ni idea, que no sabien ni el més bàsic de la diabetis, i quan he anat a dir que creia que això no era correcte $\mathrm{m}^{\prime}$ han contestat que la infermera està formada per a tot.

Infermera experta en diabetis

- Àmbit universitari: Es repeteix l'argumentari. Quan qui té la responsabilitat de coordinar una formació específica per a un grup de professionals, i aquest desconeix l'essència de la patologia en concret, la formació no té garanties d'assolir l'objectiu final, que és la capacitació dels professionals assistents a la formació.

Yo hacía un máster de diabetes y creo que la gente salía formada, al menos las evaluaciones que hacíamos eran muy positivas. Lo he dejado de hacer porque pienso que se debe hacer un máster oficial que favorezca la investigación. Para sustituir el máster que yo hacía se ofreció a otras personas, sin considerar su formación. Cuando yo me quejé de esto, me dijeron que la diabetes era transversal. Este conocimiento de que la diabetes es transversal, es simple y que cualquiera lo puede hacer es muy peligroso y esto está en las personas que tienen responsabilidad de gestión en la universidad, en el hospital, en la Atención Primaria, y esto es un peligro importante.

Dra. en Infermeria. Infermera experta en diabetis 
- S'experimenta un sentiment de pèrdua de la relació metge-infermera i del treball d'equip. Especialment a l'AP, s'han produït molts canvis en la manera de gestionar la feina de la infermera pel que fa al treball en equip, des de l'anomenada unitat bàsica assistencial (UBA), quan metge i infermera compartien els mateixos usuaris, fins a l'actualitat, quan la infermera té consulta pròpia sense formar equip amb el metge:

En molts llocs ara tampoc treballen amb l'equip metge-infermera perquè la infermera té la seva programació i tampoc hi ha un feedback. Fins fa quatre o cinc anys, encara tenia una persona dedicada a educació diabetològica i obesitat i després una altra persona que estava amb mi per fer la consulta conjuntament, i això desprès ja també ho van treure, van deixar només una infermera per fer les dues coses. La relació metge-infermera desapareix completament.

\section{Metge endocrinòleg}

Els metges tenen molt a dir en tant quant siguin capaços de demostrar i de fer veure que el tractament de la diabetis no és d'un o un altre, sinó que és d'un equip.

\section{Metge endocrinòleg}

- Avui dia, els professionals no estan preparats per desenvolupar l’ET:

Crec que l'educació diabetològica estava en nivells força més alts anys enrere. Trobo a faltar l'actitud docent de les infermeres educadores d'abans.

\section{Metge endocrinòleg}

La gent de les àrees bàsiques dels pobles no tenen aquesta formació continuada. Se'ls hi dona pel fet que l'han de saber, però no tenen la formació continuada i reglada. La gent formada era la d'abans, ara s'ha d'anar formant sobre la marxa. La formació té un caràcter més voluntari...

\section{Metge endocrinòleg}

Ara la gent no en sap. Quan es va establir la primària a tot Girona s'ha perdut.

\section{Infermera experta en diabetis}


- Conviuen diferents opinions sobre la figura de l'educador en diabetis:

- L'ús de la denominació educador en diabetis es veu com un impediment per reclamar l'especialitat:

Un error importante es la utilización del término educadora de diabetes, la enfermera formada en diabetes es una especialista, esto es un fallo.

\section{Metge endocrinòleg}

- El paper de l'educador en DM s'ha globalitzat:

Es un facilitador global de intervenciones para la salud. Para mí, hoy la figura del educador en diabetes no existe o existe en todas partes, entendido como una persona que atiende únicamente a pacientes con diabetes conflictivos. En el caso de hospitales, yo creo que la figura clásica del educador en diabetes se ha polarizado más hacia este tipo de actividades, casos difíciles, diabetes tipo 1, complicaciones.

Metge internista

\subsubsection{Visió de futur de l'educació terapèutica en diabetis per part dels professionals implicats}

La majoria d'opinions són coincidents en el sentit que una formació reglada universitària amb una acreditació d'especialitat o expertesa és la millor via per reclamar aquest reconeixement i assegurar el relleu professional, que a hores d'ara és un altre problema per a la continuïtat del treball en ET que es ve desenvolupant en la majoria d'Unitats d'Endocrinologia, Nutrició i Diabetis dels hospitals i alguns centres d'especialitats de Catalunya.

La educación es una parte fundamental, fundamentalísima de la especialización en diabetes. La formación está, lo que en nuestro país no se reconoce, no es oficial.

\section{Metge endocrinòleg}

La formación en diabetes requiere ser experto, un perfil curricular que acredite esta especialidad. Hay que intentar que la especialidad sea reconocida.

Metge endocrinòleg 
Jo crec que la via és que hi hagi l'especialitat de l'educador en diabetis.

Infermera experta en diabetis

El problema és que no hi hagi una titulació específica.

\section{Metge endocrinòleg}

Hay personas muy formadas y motivadas, pero no hay un relevo generacional y esto es un problema importante.

Dra. en Infermeria. Infermera experta en diabetis

Finalment, el 2015 la Universitat de Barcelona va endegar el primer màster oficial, el Máster para la Atención y Educación de las Personas con Diabetes, de 60 ECTS, amb la finalitat d'oferir una formació d'expert en DM, interdisciplinària i adequada per treballar com a referent d'aquesta malaltia en unitats especialitzades tant d'adults com de pediatria, i tant en centres sociosanitaris com en l'AP. A aquest màster hi poden accedir professionals de tot l'Estat espanyol i està avalat per la SED, la FEDE, I'ACD i el DESG. La SED dona una beca de 1000 euros als professionals que ho sol-licitin, prèvia valoració del seu currículum i de la seva trajectòria professional.

Cal remarcar que aquest màster ha estat el fruit d'alguns anys de treball, arran de la demanda del grup d'ET de la SED, el qual va delegar en la Dra. Pilar Isla i el Dr. Esmatjes les negociacions amb la universitat perquè fos un màster oficial

Se ha conseguido realizar un máster oficial del cual saldrán más tesis, más investigación, y esto podrá suponer en un futuro de unos diez años que haya más productividad científica y aumente el interès por la diabetes y la educación terapéutica, pero esto es el futuro y es incierto.

Dra.en Infermeria. Infermera experta en diabetis

El màster aquest que es comença ha tingut molta demanda, no sé com anirà però almenys l'expectativa és bona. Sabem que el Ministeri es va interessar molt per aquest màster, perquè és la primera titulació oficial que hi haurà a Espanya amb alguna cosa relacionada amb la diabetis, i es pot mirar si això pot encaixar en algun perfil professional. Segur que si surt bé, es farà a la resta d'Espanya, però tant de bo això serveixi perquè el Ministeri i els gerents sàpiguen que hi ha una titulació i que aleshores això planteja que hi hagin professionals que puguin estar dedicats a això.

\section{Metge endocrinòleg}


Atès que als serveis d'Endocrinologia dels hospitals es manté la figura de l'educador en DM, es reclama incorporar de nou la figura de la infermera educadora en els centres d'AP que actuï de referent per la resta de professionals.

Es tracta que fos com una obligació que hagués d'haver contractada una persona amb una formació que tingués un perfil d'infermera experta. Jo crec que això s'ha d'anar treballant, perquè aquesta línia veig com si s’hagués aturat. Ho veig una mica massa aturat, per part de tothom.

\section{Metge endocrinòleg}

A primària necessiten la figura de la infermera referent, necessiten una persona que realment s'hi dediqui, a això. El que passa és que en aquesta figura hi ha gent que hi creu i hi ha gent que no, però des de primària hi hauria d'haver aquesta motivació, d'infermeres referents, que en fan falta.

Infermera experta en diabetis

Hi ha d'haver experts superiors en educació, seguríssim, perquè la infermera de primària té moltes coses a fer. Hi ha d'haver les més especialitzades, com pot ser la de diabetis, la de cardiologia, la de nefrologia, que tenen l'obligació de donar suport a la primària. Però hi ha molt poca gent que vulgui lluitar per això.

Metge endocrinòleg

Ara, doncs, cal treballar perquè l'Administració reconegui aquesta formació com a indispensable per a l'atenció cost-efectiva de les persones amb DM en qualsevol àmbit. Només si professionals i els pacients s'uneixen en aquesta demanda, pot ser possible produir un canvi en la visió d'aquells que tenen la responsabilitat de dissenyar línies i estratègies d'actuació en l'àmbit polític envers el complex món de la cronicitat.

\subsection{Resultats de la segona fase de l'estudi}

Dels 69 hospitals d'aguts de la xarxa de centres d'internament d'utilització pública de Catalunya, se'n van identificar 44 que disposaven de servei d'educació especialitzada. A aquests s'hi van afegir l'Hospital de Nens de Barcelona i l'Hospital General de Catalunya perquè també tenien servei d'Endocrinologia amb infermeres educadores de diabetis. En el conjunt dels 46 hospitals es va comptabilitzar un total de 77 professionals d'infermeria dedicats a l'educació terapèutica en diabetis als quals es va enviar el qüestionari; hi van respondre 70 (94,8 \%). Dels 97 centres d'assistència primària seleccionats en el mostreig per conglomerats d'entre els 364, finalment es va obtenir una mostra de 217 professionals. 


\subsubsection{Característiques sociodemogràfiques i perfil professional}

La distribució geogràfica de la mostra va ser la següent: 198 professionals d'infermeria (68,9\%) treballaven a la província de Barcelona, 39 (13,5 \%) a la província de Tarragona, 18 (6,2 \%) a la de Lleida i $32(11,1 \%$ ) a la de Girona (gràfic 1$)$.

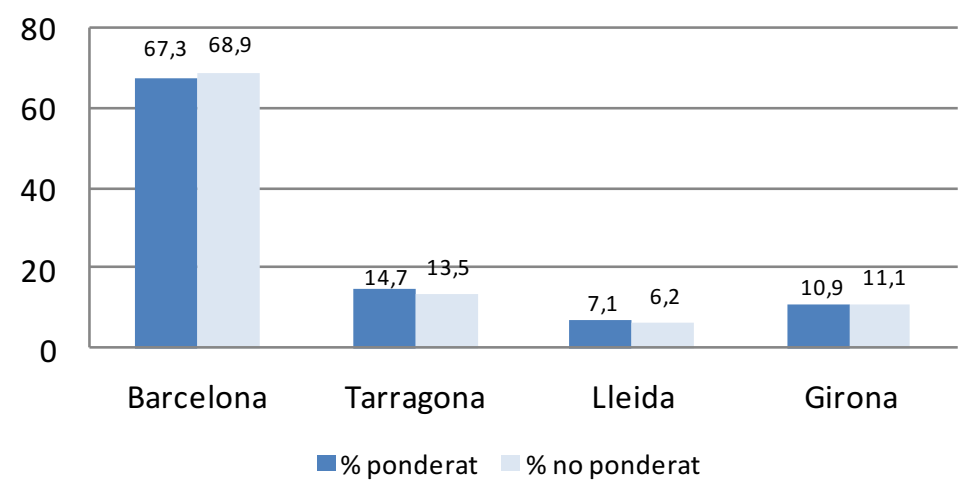

Gràfic 1: Distribució per províncies del total de la mostra

Al dividir la mostra per àmbits d'atenció, assistència primària (AP) i assistència especialitzada (AE), un 66,2\% dels professionals de l'AP i un 87,9\% de l'AE corresponen a la província de Barcelona; un $15 \%$ de l'AP i un 9,4\% de l'AE a la de Tarragona; un 7,9\% de l'AP i un 1,6\% de I'AE a la de Lleida, i un 11,5\% de l'AP i un 1,6 \% de l'AE a la de Girona (gràfic 2).

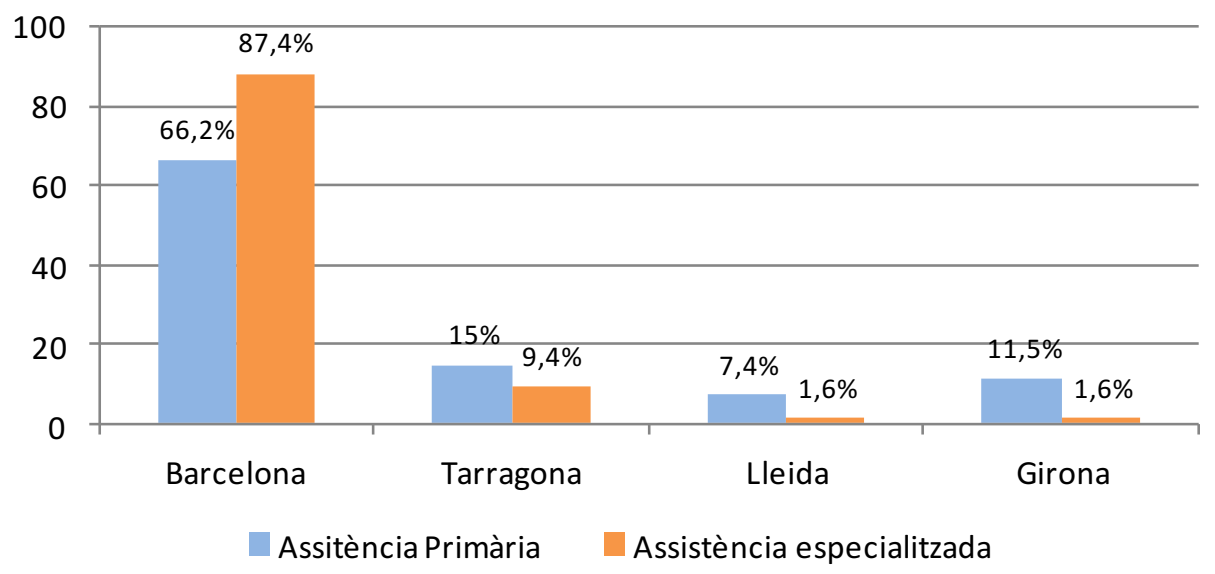

Gràfic 2: Distribució de la mostra per províncies i tipus d'assistència (dades no ponderades) 
Respecte a l'àmbit territorial, 206 professionals (71,7 \%) pertanyien a l'àmbit urbà (gràfic 3), dels quals el $90,6 \%$ treballaven a l'assistència especialitzada i el 66,3 \%, a la primària (gràfic 4).

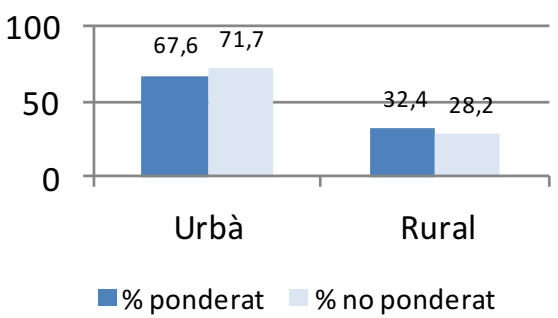

Gràfic 3: Àmbit territorial (total de la mostra)

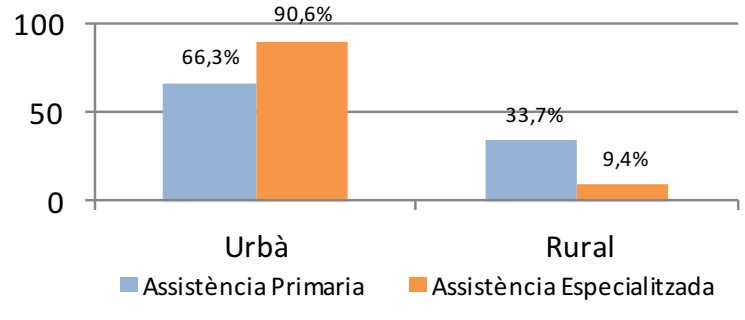

Gràfic 4: Àmbit territorial per tipus d'assistència (dades ponderades)

Les característiques sociodemogràfiques i l'àmbit de treball es descriuen a la taula 4. L'edat mitjana dels professionals inclosos a la mostra va ser de 47,3 anys $\pm 9,16$, dels quals el $94,1 \%$ eren dones, i el $96,5 \%$, diplomats en Infermeria. Del total, 70 professionals $(24,3 \%)$ treballaven a l'AE i 217 (75,6 \%), a l'AP. El 85,3 \% treballaven a temps complet. Dividida la mostra per àmbits d'assistència, s'observa que l'edat mitjana estimada dels professionals de l'AE és superior a la dels de l'AP: 51,39 \pm 0,7 davant 45,99 \pm 1,3 (taula 5).

Els anys d'experiència professional es van valorar per anys treballats en els diferents àmbits ( $A P$, centre d'especialitats, consultes externes d'hospital, hospitalització o altres), i es va obtenir una mitjana d'anys treballats de $17,41 \pm 11,9$. Els professionals amb un promig d'anys treballats més alt van ser els de l'AP $(19,88 \pm 9)$, mentre que el promig més baix va recaure en els professionals de centres d'especialitats $(9,48 \pm 10,75)$. 
Taula 4: Característiques personals i perfil professional de la població estudiada

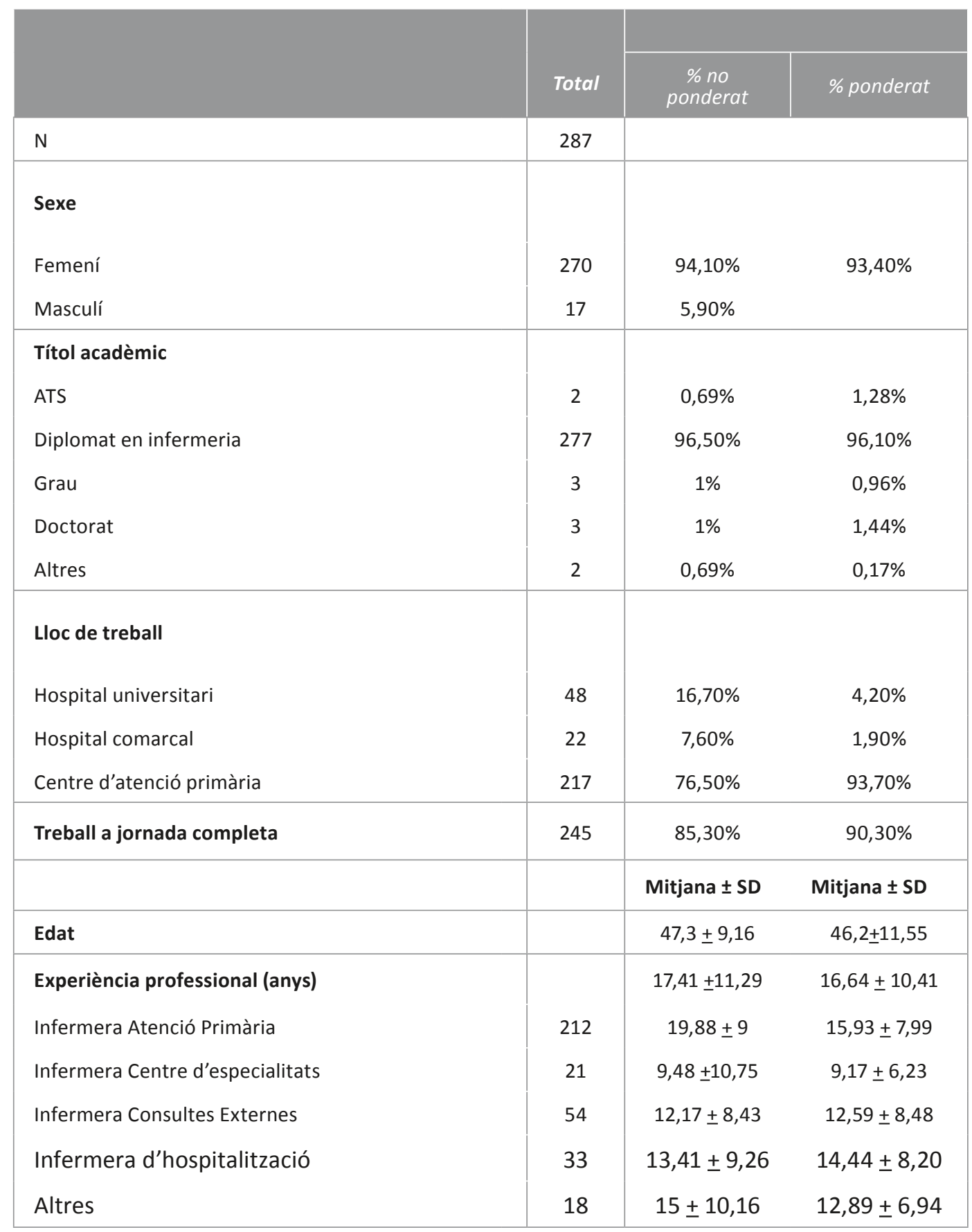


Taula 5. Edat mitjana dels professionals per àmbit d'assistència

\begin{tabular}{|l|c|c|c|c|}
\hline \multirow{2}{*}{} & \multirow{2}{*}{ Estimació } & \multirow{2}{*}{ Error típic } & \multicolumn{2}{|c|}{ Interval de confiança al $95 \%$} \\
\cline { 3 - 5 } & & & Inferior & Superior \\
\hline Assistència Primària & 45,99 &, 706 & 44,59 & 47,39 \\
\hline Assistència Especialitzada & 51,39 & 1,352 & 48,72 & 54,07 \\
\hline
\end{tabular}

\subsubsection{Formació específica i experiència en diabetis}

La formació específica en diabetis i l'experiència en diabetis dels professionals d'infermeria es descriuen a la taula 6 . En conjunt, els resultats mostren un baix nivell de formació universitària en les diferents àrees relacionades amb la diabetis de nivell màster o postgrau, ja que només el $26,6 \%$ responen que acumulen $>200$ hores de formació acreditada; i tenint en compte l'efecte del disseny, aquest percentatge descendiria encara més fins a situar-se al voltant del $20,1 \%$, a diferència de la formació continuada, on el 81,5 \% (estimació ponderada del 76,2 \%) responen haver realitzat cursos de formació continuada en diabetis, i aproximadament el $60 \%$ (54,4 \% d'estimació ponderada), de dietètica i nutrició.

Quan es comparen els professionals de l'AP amb els de l'AE s'observa que els professionals d'infermeria de l'AE tenen més hores de formació acreditada $(p<0,001)$, més formació específica en diabetis de nivell universitari: pel que fa a màster, el $12,6 \%$ davant el $1,9 \%, p<0,001$; quant a postgrau, el $48,1 \%$ davant el $13,8 \%$ ( $p<0,001)$; en relació amb la dietètica i nutrició, el $26,1 \%$ davant el $10,3 \%$ ( $p=0,019)$; també més la formació continuada en diabetis (el 98,4 \% davant el 74,9, p < 0,001) i educació terapèutica (el 79,6 \% davant el 24,8\%, p<0,001).

El $47 \%$ dels enquestats referien més de 15 anys d'experiència en l'atenció de les persones amb diabetis, cosa que, tot i ser lleugerament superior a l'AE, no revela diferències estadísticament significatives entre ambdós àmbits d'assistència. 
Taula 6: Formació i experiència en diabetis dels professionals per àmbit d'assistència

\begin{tabular}{|c|c|c|c|c|c|c|c|c|}
\hline & \multicolumn{3}{|c|}{ Total } & \multicolumn{2}{|c|}{ Assistència Primària } & \multicolumn{2}{|c|}{$\begin{array}{c}\text { Assistència } \\
\text { Especialitzada }\end{array}$} & \multirow[b]{2}{*}{$\operatorname{Sig}(p)$} \\
\hline & Si & $\begin{array}{c}\% \text { no } \\
\text { ponderat }\end{array}$ & $\begin{array}{c}\% \\
\text { ponderat }\end{array}$ & $\begin{array}{c}\% \text { no } \\
\text { ponderat }\end{array}$ & $\begin{array}{c}\% \\
\text { ponderat }\end{array}$ & $\begin{array}{c}\% \text { no } \\
\text { ponderat }\end{array}$ & $\begin{array}{c}\% \\
\text { ponderat }\end{array}$ & \\
\hline \multicolumn{9}{|l|}{$\begin{array}{l}\text { Formació } \\
\text { universitària }\end{array}$} \\
\hline $\begin{array}{l}\text { Postgrau en } \\
\text { Diabetis }\end{array}$ & 55 & 19,1 & 15,6 & 12,6 & 13,8 & 44,8 & 48,1 & $<0,001$ \\
\hline $\begin{array}{l}\text { Màster en } \\
\text { Diabetis }\end{array}$ & 11 & 3,8 & 1,8 & 1,3 & 1,9 & 13,8 & 12,6 & $<0,001$ \\
\hline $\begin{array}{l}\text { Postgrau en } \\
\text { Dietètica i } \\
\text { Nutrició }\end{array}$ & 34 & 11,8 & 11,1 & 9,6 & 10,3 & 20,6 & 26,1 & 0,019 \\
\hline $\begin{array}{l}\text { Màster en } \\
\text { Dietèticá i } \\
\text { Nutrició }\end{array}$ & 10 & 3,4 & 4,3 & 3,4 & 4,4 & 3,4 & 3,1 & 0,674 \\
\hline $\begin{array}{l}\text { Programa } \\
\text { ENDCUP }\end{array}$ & 4 & 1,3 & 0,7 & 0,4 & 0,5 & 5,17 & 4,7 & 0,028 \\
\hline \multicolumn{9}{|l|}{$\begin{array}{l}\text { Formació } \\
\text { continuada }\end{array}$} \\
\hline Diabetis & 234 & 81,5 & 76,2 & 77,3 & 74,9 & 98,3 & 98,4 & $<0,001$ \\
\hline $\begin{array}{l}\text { Dietètica i } \\
\text { Nutrició }\end{array}$ & 169 & 58,8 & 54,4 & 55,9 & 53,8 & 70,7 & 66 & 0,186 \\
\hline $\begin{array}{l}\text { Educació } \\
\text { Terapèutica }\end{array}$ & 107 & 37,2 & 27,7 & 27,1 & 24,8 & 77,6 & 79,6 & $<0,001$ \\
\hline Altres & 35 & 12,1 & 10,9 & 11,4 & 10,7 & 15,5 & 14,1 & 0,525 \\
\hline $\begin{array}{l}\text { Hores de } \\
\text { formació } \\
\text { acreditada }\end{array}$ & & & & & & & & $<0,001$ \\
\hline$<30 \mathrm{~h}$ & 46 & 16,1 & 21,6 & 19,3 & 22,6 & 3,5 & 3,4 & \\
\hline $30-50 \mathrm{~h}$ & 57 & 20,0 & 19,6 & 23,2 & 20,4 & 7,0 & 6,9 & \\
\hline $50-100 \mathrm{~h}$ & 55 & 19,2 & 21,2 & 20,6 & 21,7 & 14,0 & 13,8 & \\
\hline $100-200 \mathrm{~h}$ & 50 & 17,5 & 16,8 & 17,1 & 16,7 & 19,3 & 20,7 & \\
\hline$>200 \mathrm{~h}$ & 76 & 26,6 & 20,1 & 19,3 & 18,2 & 56,1 & 52,2 & \\
\hline $\begin{array}{l}\text { Anys } \\
\text { d'experiència } \\
\text { en diabetis }\end{array}$ & & & & & & & & 0,830 \\
\hline$<1$ any & 3 & 1,0 & 1,1 & 1,3 & 1,2 & 0 & 0 & \\
\hline 1-2 anys & 5 & 1,7 & 2,0 & 1,7 & 2 & 1,7 & 1,6 & \\
\hline $2-5$ anys & 20 & 6,9 & 5,8 & 5,7 & 5,5 & 12,1 & 11,1 & \\
\hline $5-10$ anys & 45 & 15,6 & 13,8 & 14,4 & 13,4 & 20,7 & 20,4 & \\
\hline $10-15$ anys & 70 & 27,5 & 31,0 & 30,1 & 31,9 & 17,2 & 15,7 & \\
\hline$>15$ anys & 135 & 47,0 & 46,1 & 46,7 & 45,9 & 48,3 & 51,3 & \\
\hline
\end{tabular}




\subsubsection{Càrregues de treball}

Els professionals d'infermeria atenen una mitjana de 62,32 \pm 7,03 pacients amb diabetis al mes. Al separar les càrregues de treball per àmbits d'assistència s'observa que a l'AE la mitjana de pacients amb diabetis atesos en un mes és significativament major que la de l'AP (159,42 davant $56,66)$. A l'AE el percentatge de pacients atesos en un mes amb DM1, DM gestacional i altres formes de diabetis supera el de l'AP $(p<0,001)$, mentre que a l'AP atenen més pacients amb DM2 i prediabetis $(p<0,001)$ (taula 7$)$.

Taula 7: Total de pacients amb diabetis i percentatge de pacients atesos segons el tipus de diabetis en un mes a cada àmbit d'assistència

\begin{tabular}{|c|c|c|c|c|c|c|c|}
\hline & \multirow{2}{*}{$\begin{array}{l}\text { Total de } \\
\text { pacients } \\
\text { amb DM }\end{array}$} & \multicolumn{6}{|c|}{$\%$ de pacients segons tipus de diabetis } \\
\hline & & $\begin{array}{l}\text { Diabetis } \\
\text { tipus } 1\end{array}$ & $\begin{array}{l}\text { Diabetis } \\
\text { tipus } 2\end{array}$ & $\begin{array}{c}\text { Diabetis } \\
\text { gestacional }\end{array}$ & Prediabetis & Altres & $\begin{array}{c}\text { No ho } \\
\text { sap }\end{array}$ \\
\hline $\begin{array}{c}\text { Assistència } \\
\text { Primària }\end{array}$ & 56,66 & $5,87 \%$ & $74,10 \%$ & $1,63 \%$ & $6,11 \%$ & $1,37 \%$ & $10,50 \%$ \\
\hline $\begin{array}{c}\text { Assistència } \\
\text { Especialitzada }\end{array}$ & 159,42 & $35,14 \%$ & $44,80 \%$ & $9,13 \%$ & $1,52 \%$ & $6,55 \%$ & $1,60 \%$ \\
\hline Sig (p) & $<0,001$ & $<0,001$ & $<0,001$ & $<0,001$ & $<0,001$ & $<0,001$ & $<0,003$ \\
\hline
\end{tabular}

A la taula 8 es mostra la distribució per grups d'edat dels pacients atesos segons l'àmbit d'assistència. Es pot observar que en el cas de l'AP el percentatge més elevat va correspondre als majors de 64 anys, que van suposar el 57,54 \% del total, seguits pels pacients d'entre 45 i 64 anys, amb un 21,79\%. En canvi, en l'AE la distribució va ser més homogènia: es van observar percentatges que van oscil.lar entre el $23 \%$ i el $28 \%$ en edats compreses entre els 19 i 44, 45 i 64 anys i els majors de 64 anys. Totes les diferències observades en cada grup d'edat entre tots dos àmbits d'assistència van ser estadísticament significatives.

Taula 8: Distribució d'edats dels pacients atesos per àmbit d'assistència (percentatge)

\begin{tabular}{|l|l|l|l|l|l|}
\hline & $\begin{array}{l}\text { Menys de 19 } \\
\text { anys }\end{array}$ & $\begin{array}{l}\text { De } 19 \text { a } 44 \\
\text { anys }\end{array}$ & $\begin{array}{l}\text { De } 45 \text { a } 64 \\
\text { anys }\end{array}$ & > de 65 anys & No ho sap \\
\hline $\begin{array}{l}\text { Assistència } \\
\text { Primària }\end{array}$ & $1,60 \%$ & $6,14 \%$ & $21,79 \%$ & $57,54 \%$ & $12,63 \%$ \\
\hline $\begin{array}{l}\text { Assistència } \\
\text { Especialitzada }\end{array}$ & $13,34 \%$ & $23,86 \%$ & $28,02 \%$ & $28,31 \%$ & $6,29 \%$ \\
\hline Sig $(p)$ & 0,032 & $<0,001$ & 0,029 & $<0,001$ & 0,114 \\
\hline
\end{tabular}


D'altra banda, un $71 \%$ (estimació ponderada del 74,4 \%) van considerar que les persones amb barreres idiomàtiques que atenen són menys del $10 \%$, però un $21 \%$ (estimació ponderada del $17,5 \%$ ) dels professionals diuen atendre entre el 10 i el $20 \%$ de persones amb barreres idiomàtiques. No es van observar diferències significatives en ambdós àmbits d'assistència (taula 9).

Taula 9: Pacients amb barreres idiomàtiques (percentatge)

\begin{tabular}{|c|c|c|c|c|c|c|c|c|}
\hline & & & & Assistènc & Primària & $\begin{array}{r}\text { Assis } \\
\text { Especi }\end{array}$ & $\begin{array}{l}\text { ècia } \\
\text { litzada }\end{array}$ & \\
\hline & Total & $\begin{array}{c}\% \text { no } \\
\text { ponderat }\end{array}$ & $\begin{array}{c}\% \\
\text { ponderat }\end{array}$ & $\begin{array}{c}\% \text { no } \\
\text { ponderat }\end{array}$ & $\begin{array}{c}\% \\
\text { ponderat }\end{array}$ & $\begin{array}{c}\% \text { no } \\
\text { ponderat }\end{array}$ & $\begin{array}{c}\% \\
\text { ponderat }\end{array}$ & $\operatorname{Sig}(p)$ \\
\hline $\begin{array}{l}\text { Percentatge } \\
\text { de pacients } \\
\text { amb barreres } \\
\text { idiomàtiques }\end{array}$ & & & & & & & & 0,601 \\
\hline$<10 \%$ & 200 & 71 & 74,4 & 73,5 & 75 & 62,1 & 65,4 & \\
\hline $10-20 \%$ & 59 & 21 & 17,5 & 20,2 & 17,3 & 24,1 & 22 & \\
\hline $20-50 \%$ & 17 & 6 & 5,2 & 4,5 & 5 & 12,1 & 11 & \\
\hline$>50 \%$ & 1 & 0,3 & 0,3 & 0,4 & 0,3 & 0 & 0 & \\
\hline Ho desconeix & 4 & 1,4 & 2,3 & 1,3 & 2,4 & 1,7 & 1,6 & \\
\hline
\end{tabular}

\subsubsection{Relació/col-laboració amb altres professionals}

Es va estimar que la relació professional i el treball interdisciplinari es dona bàsicament dins el mateix àmbit d'atenció. Així, les infermeres de l'AP col·laboren bàsicament entre elles i el metge de família en un $81,60 \%$ i un 96,30 \%, respectivament, mentre que a l'AE també entre elles i l'endocrinòleg ho fan en un $82,70 \%$ i un $96,90 \%$, respectivament. A més, mentre que un percentatge estimat del $40,70 \%$ dels professionals d'infermeria de l'AP va manifestar que col-laborava amb l'endocrinòleg, només un 32,40 \% dels professionals de l'AE ho feien amb el metge d'assistència primària. A l'AP referien tenir una major col·laboració amb l'oftalmòleg i el podòleg, tot i que la diferència no va ser estadísticament significativa, i a l'AE amb el dietista, l'assistent social i el psicòleg, essent en aquest cas significatives totes les diferències (taula 10). 
Taula 10: Relació/col·laboració amb altres professionals per àmbit d’assistència

\begin{tabular}{|c|c|c|c|c|c|c|c|c|}
\hline & & & & $\begin{array}{r}\text { Assis } \\
\text { Prir }\end{array}$ & $\begin{array}{l}\text { tència } \\
\text { iària }\end{array}$ & $\begin{array}{l}\text { Assis } \\
\text { Especic }\end{array}$ & $\begin{array}{l}\text { ència } \\
\text { litzada }\end{array}$ & \\
\hline & Total & $\begin{array}{c}\% \text { no } \\
\text { ponderat }\end{array}$ & $\begin{array}{c}\% \\
\text { ponderat }\end{array}$ & $\begin{array}{c}\% \text { no } \\
\text { ponderat }\end{array}$ & $\%$ ponderat & $\begin{array}{c}\% \text { no } \\
\text { ponderat }\end{array}$ & $\begin{array}{c}\% \\
\text { ponderat }\end{array}$ & $\operatorname{Sig}(p)$ \\
\hline $\begin{array}{l}\text { Professionals am } \\
\text { qui col-labora }\end{array}$ & & & & & & & & \\
\hline $\begin{array}{l}\text { Companys } \\
\text { infermeria }\end{array}$ & 236 & 82,50 & 81,60 & 82,80 & 81,60 & 81 & 82,70 & 0,856 \\
\hline Endocrinòleg & 154 & 53,80 & 43,70 & 43 & 40,70 & 96,50 & 96,90 & $<0,001$ \\
\hline Metge AP & 228 & 79,70 & 92,70 & 93 & 96,30 & 28 & 32,40 & $<0,001$ \\
\hline Oftalmòleg & 53 & 18,50 & 20,10 & 20,60 & 20,80 & 10,30 & 9,40 & 0,073 \\
\hline Podòleg & 120 & 41,90 & 46,20 & 44,20 & 47,20 & 32,70 & 29,90 & 0,106 \\
\hline Dietista & 58 & 20,20 & 14,10 & 13 & 12,40 & 48,20 & 44 & $<0,001$ \\
\hline Assist. social & 60 & 20,90 & 20,20 & 18 & 19,30 & 32,70 & 37,10 & 0,027 \\
\hline Psicòleg & 16 & 5,50 & 2,70 & 2,20 & 1,90 & 19 & 17,30 & $<0,001$ \\
\hline Altres & 18 & 6,20 & 6,20 & 5,20 & 6,10 & 10,30 & 9,40 & 0,388 \\
\hline
\end{tabular}

\subsubsection{Prestacions, estructura de l'educació terapèutica, tipus d’educació i recursos}

Tipus de prestacions: Es van evidenciar diferències significatives en algunes de les prestacions que els professionals d'infermeria ofereixen als pacients segons l'àmbit d'atenció. Així, la deshabituació del tabac, l'exploració dels peus, el control de la dislipèmia, l'exploració oftalmològica i el seguiment del calendari vacunal i el maneig de l'estrès es treballaven més a l'AP. En la resta de prestacions no hi ha diferències significatives entre primària i especialitzada, tot i que el maneig de la medicació va apuntar una significació estadística a favor de l'AE $(p=0,069)$ (taula 11). 
Taula 11: Prestacions que els professionals d'infermeria ofereixen als pacients, per àmbit d'assistència

\begin{tabular}{|c|c|c|c|c|c|c|c|c|}
\hline & & & & $\begin{array}{l}\text { Assistènci } \\
\text { Primària }\end{array}$ & & $\begin{array}{l}\text { Assistènci } \\
\text { Especialitz }\end{array}$ & ada & \\
\hline & Total & $\begin{array}{l}\% \text { no } \\
\text { ponderat }\end{array}$ & $\begin{array}{l}\% \\
\text { ponderat }\end{array}$ & $\begin{array}{l}\% \text { no } \\
\text { ponderat }\end{array}$ & $\begin{array}{l}\% \\
\text { ponderat }\end{array}$ & $\begin{array}{l}\% \text { no } \\
\text { ponderat }\end{array}$ & $\begin{array}{l}\% \\
\text { ponderat }\end{array}$ & $\operatorname{Sig}(p)$ \\
\hline Tipus de prestacions & & & & & & & & \\
\hline Maneig de medicació & 269 & 94 & 92 & 93 & 91,4 & 98,2 & 98,4 & 0,069 \\
\hline Deshabituació tabac & 215 & 75 & 84,50 & 83,7 & 86,8 & 41,3 & 44,9 & $<0,001$ \\
\hline Suport psicològic & 175 & 61 & 59,60 & 60 & 59,2 & 65,5 & 66,9 & 0,368 \\
\hline Exploració dels peus & 263 & 92 & 97,50 & 97 & 98,8 & 72,4 & 74,8 & $<0,001$ \\
\hline $\begin{array}{l}\text { Estratègies pèrdua } \\
\text { pes }\end{array}$ & 273 & 95,40 & 95,70 & 94,7 & 95,5 & 98,2 & 98,4 & 0,304 \\
\hline Educació grupal & 141 & 49,30 & 44,60 & 46 & 43,5 & 62 & 63,8 & 0,031 \\
\hline Seguiment telefònic & 169 & 59 & 56,30 & 57 & 55,6 & 67,2 & 68,5 & 0,132 \\
\hline $\begin{array}{l}\text { Educació per a } \\
\text { l'exercici }\end{array}$ & 262 & 91,60 & 92,10 & 92,1 & 92,3 & 89,6 & 88,9 & 0,464 \\
\hline $\begin{array}{l}\text { Consells per a } \\
\text { trastorns aliment. }\end{array}$ & 177 & 61,80 & 62,60 & 65 & 63,1 & 50 & 54,4 & 0,314 \\
\hline $\begin{array}{l}\text { Individualització pla } \\
\text { aliment. }\end{array}$ & 267 & 93,30 & 93 & 93,4 & 93 & 93,1 & 93,7 & 0,856 \\
\hline Control dislipèmia & 248 & 86,70 & 91,80 & 92,5 & 93,2 & 63,7 & 66,9 & $<0,001$ \\
\hline $\begin{array}{l}\text { Exploració } \\
\text { oftalmològica }\end{array}$ & 157 & 54,80 & 63,30 & 61,8 & 65,1 & 27,5 & 32,4 & 0,001 \\
\hline Calendari vacunal & 214 & 74,80 & 91,50 & 92,1 & 96 & 6,9 & 13,5 & $<0,001$ \\
\hline Maneig de l'estrès & 111 & 38,80 & 42 & 42,5 & 43,1 & 24,1 & 22 & 0,022 \\
\hline Altres & 25 & 8,70 & 6,80 & 7,9 & 6,5 & 12 & 11 & 0,296 \\
\hline
\end{tabular}

A la taula 12 es descriu com s'estructura l'educació terapèutica en diabetis i quin tipus d'atenció es proporciona en ambdós àmbits assistencials (AP i AE).

El 60,7 \% del total dels professionals van afirmar que utilitzaven programes estructurats per a l'educació dels pacients. Quan es divideix la mostra per àmbits d'assistència s'observa que és a l'AE on s'utilitza més l'educació estructurada (el 75,4 \% davant el $51,3 \%, p=0,028$ ), bàsicament programes dirigits a DM 1, DM 2 i diabetis gestacional. Hi ha una manca de programes estructurats per a l'atenció al peu diabètic en ambdós àmbits (27,6 \% a l'AP i 28,7 \% a l'AE). S'estima que un 31,8\% dels professionals de l'AP no tenen cap programa estructurat per a 
l'educació de pacients, a diferència de l'11,1 \% que es dona a l'AE ( $p<0,001)$. D'altra banda, el $16,1 \%$ d'ABS i el $14,3 \%$ de centres d'AE apliquen el programa «Pacient Expert Catalunya».

S'estima que només el $48 \%$ del total de professionals té els programes educatius per escrit. Malgrat que el percentatge de professionals de l'AE que van respondre que tenien programes d'educació estructurada és alt (el $81 \%$, amb una estimació ponderada del 75,4 \%), només el $67,9 \%$ deia tenir-los per escrit (estimació ponderada del 69,2 \%), i la mateixa relació s'estableix a l'AP, on s'estima que el 51,3 \% tindrien programes estructurats, però només el 46,8 \% els tindria per escrit. Aquestes diferències van ser estadísticament significatives.

No es van observar diferències significatives en la realització d'activitats monotemàtiques entre ambdós àmbits d'assistència, donat que els percentatges es van estimar en el 56,1 \% per a l'AP, i el 59,1 \% per a l'AE. Tampoc es van observar diferències significatives pel que fa a la realització d'activitats educatives a demanda.

Coordinació entre nivells assistencials: Tot i que destaca la poca coordinació entre ambdós nivells assistencials, aquesta va ser més acusada en el cas de l'atenció primària, on només el 23,2 \% (estimació ponderada del 20,8 \%) de professionals van referir tenir-la amb l'AE, mentre que en el cas de l'AE, aquest percentatge va ser del $41,3 \%$ (estimació ponderada del 46,5\%), diferència que va ser estadísticament significativa $(p<0,001)$.

Metodologia educativa i infraestructura: Els programes que combinen l'educació individual amb la grupal estan més presents a l'AE (el $68 \%$ davant el 48,2 \%, p =0,036), tot i que en l'AP refereixen tenir més infraestructura, com es el fet de poder disposar d'una aula adient i de fàcil accés (el 87,6 \% davant el 70,1\%, p =0,009).

Materials de suport a l'educació: Gairebé la totalitat dels professionals, sense diferències significatives entre assistència primària i especialitzada $(98,4 \%$ i 97,9\%, respectivament, $p=0,809)$ utilitzen els fullets com a material principal de suport a l'educació dels pacients, majoritàriament proporcionats per la indústria farmacèutica (74,7 \%). És a l'assistència especialitzada on bàsicament s'utilitzen altres tipus de materials com ara llibres, DVD o pàgines web $(p<0,001)$.

Participació de la família: La participació de la família en les activitats educatives es més gran a l'AE, on un $65 \%$ (estimació ponderada del 59,1 \%) dels professionals responen que la família pren part quasi sempre en l'educació del pacient, davant el 32,5 \% (estimació ponderada del $33 \%$ ) en l'AP. Tot i que treballant amb totes les categories de resposta de la participació de la família, les diferències no van ser significatives al nivell de 0,05 (però sí al de $0,10, p=0,083$ ), es van detectar diferències estadísticament significatives en comparar la categoria «quasi sempre» esmentada anteriorment amb la resta de categories (agrupades). 
Taula 12: Estructura, tipus d'educació terapèutica i recursos, per àmbit d'assistència

\begin{tabular}{|c|c|c|c|c|c|c|c|c|}
\hline & \multirow[b]{2}{*}{ Total } & \multirow[b]{2}{*}{$\begin{array}{c}\% \text { no } \\
\text { ponderat }\end{array}$} & \multirow[b]{2}{*}{$\begin{array}{c}\% \\
\text { ponderat }\end{array}$} & \multicolumn{2}{|c|}{$\begin{array}{l}\text { Assistència } \\
\text { Primària }\end{array}$} & \multicolumn{2}{|c|}{$\begin{array}{c}\text { Assistència } \\
\text { Especialitzada }\end{array}$} & \multirow[b]{2}{*}{$\operatorname{Sig}(p)$} \\
\hline & & & & $\begin{array}{c}\% \text { no } \\
\text { ponderat }\end{array}$ & \begin{tabular}{c|c}
$\%$ \\
ponderat
\end{tabular} & $\begin{array}{c}\% \text { no } \\
\text { ponderat }\end{array}$ & \begin{tabular}{c|c}
$\%$ \\
ponderat
\end{tabular} & \\
\hline Programes estructurats & 173 & 60,70 & 52,70 & 55,5 & 51,3 & 81 & 75,4 & 0,028 \\
\hline \multicolumn{9}{|l|}{ Tipus de programes: } \\
\hline Per DM 1 & 62 & 22,70 & 8,80 & 8,3 & 5,13 & 77,1 & 71,8 & $\begin{array}{c}< \\
0,001\end{array}$ \\
\hline Per DM 2 & 159 & 58,20 & 52,60 & 54,6 & 51,3 & 72 & 74,4 & 0,016 \\
\hline Per DM gestacional & 47 & 17,20 & 5,70 & 6,4 & 2,81 & 57,8 & 54,2 & 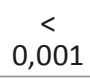 \\
\hline Per a peu diabètic & 80 & 29,30 & 27,70 & 28,7 & 27,6 & 31,5 & 28,7 & 0,901 \\
\hline $\begin{array}{l}\text { «Pacient Expert } \\
\text { Catalunya» }\end{array}$ & 46 & 16,80 & 16 & 15,6 & 16,1 & 14 & 14,3 & 0,805 \\
\hline Cap & 80 & 29,30 & 36,60 & 33,8 & 38,1 & 12,2 & 11,1 & $\begin{array}{c}< \\
0,001\end{array}$ \\
\hline Altres & 22 & 8 & 5,70 & 6 & 5,2 & 15,5 & 14,1 & 0,048 \\
\hline $\begin{array}{l}\text { Programes estructurats } \\
\text { coordinats AP-H }\end{array}$ & 76 & 26,90 & 22,20 & 23,2 & 20,8 & 41,3 & 46,5 & $\begin{array}{c}< \\
0,001\end{array}$ \\
\hline Programes per escrit & 135 & 50,70 & 48 & 46,2 & 46,8 & 67,9 & 69,2 & 0,016 \\
\hline $\begin{array}{l}\text { Activitats educatives } \\
\text { monotemàtiques }\end{array}$ & 163 & 57,10 & 56,20 & 57 & 56,1 & 56,8 & 59,1 & 0,717 \\
\hline Educació a demanda & 160 & 56,50 & 56,10 & 56,4 & 56,3 & 56,1 & 51,9 & 0,625 \\
\hline \multicolumn{9}{|l|}{ Tipus d'educació: } \\
\hline Individual & 279 & 98,20 & 97,70 & 98,2 & 97,7 & 98,2 & 98,4 & 0,765 \\
\hline Individual + grupal & 154 & 54,40 & 50,60 & 50,8 & 48,2 & 68,4 & 68 & 0,036 \\
\hline $\begin{array}{l}\text { Participació de la } \\
\text { família: }\end{array}$ & & & & & & & & 0,083 \\
\hline Quasi sempre & 105 & 39,40 & 34,40 & 32,5 & 33 & 65 & 59,1 & \\
\hline Algunes vegades & 150 & 56,30 & 58,70 & 62,2 & 59,8 & 35 & 40,9 & \\
\hline Quasi mai & 11 & 4,10 & 6,80 & 5,3 & 7,2 & 0 & 0 & \\
\hline \multicolumn{9}{|l|}{ Infraestructura: } \\
\hline Aula & 240 & 83,90 & 86,60 & 87,7 & 87,6 & 69 & 70,1 & 0,009 \\
\hline Despatx & 276 & 96,50 & 95,30 & 96,6 & 95 & 100 & 100 & 0,402 \\
\hline
\end{tabular}




\begin{tabular}{|c|c|c|c|c|c|c|c|c|}
\hline Ús de la via telemàtica & 157 & 54,70 & 46,50 & 47,5 & 44,4 & 82,7 & 84,2 & $\begin{array}{c}< \\
0,001\end{array}$ \\
\hline \multicolumn{9}{|l|}{ Mitjans telemàtics: } \\
\hline Telèfon & 137 & 53,50 & 43,10 & 46 & 41,2 & 80,4 & 74,6 & 0,002 \\
\hline $\begin{array}{l}\text { Plataf. descàrr. } \\
\text { mesuradors }\end{array}$ & 55 & 21,40 & 10 & 10,5 & 7,2 & 60,7 & 56,8 & $\begin{array}{c}< \\
0,001\end{array}$ \\
\hline $\begin{array}{l}\text { Plataf. descàr. bombes/ } \\
\text { sensors }\end{array}$ & 33 & 12,80 & 3,80 & 3 & 1,2 & 48,2 & 45,4 & $\begin{array}{c}< \\
0,001\end{array}$ \\
\hline Progr. Educ en línia & 31 & 12,10 & 7,60 & 7 & 5,9 & 30,4 & 35,1 & $\begin{array}{c}< \\
0,001\end{array}$ \\
\hline Altres & 17 & 6,60 & 5,20 & 5 & 4,9 & 12,5 & 11,4 & 0,114 \\
\hline \multicolumn{9}{|l|}{ Material de suport: } \\
\hline Fullets & 281 & 97,90 & 97,90 & 97,8 & 97,9 & 98,2 & 98,4 & 0,809 \\
\hline Llibres & 80 & 27,80 & 13,90 & 13,1 & 9,7 & 86,2 & 87,4 & $\begin{array}{c}< \\
0,001\end{array}$ \\
\hline DVD & 31 & 10,80 & 6 & 6,1 & 4,9 & 29,3 & 26,7 & $\begin{array}{c}< \\
0,001\end{array}$ \\
\hline Webs & 123 & 42,80 & 34,40 & 34,4 & 32,3 & 75,8 & 70,7 & $<0,001$ \\
\hline \multicolumn{9}{|l|}{ Font dels materials: } \\
\hline Elaboració pròpia & 128 & 44,50 & 37 & 34,9 & 34,7 & 82,7 & 77 & $\begin{array}{c}< \\
0,001\end{array}$ \\
\hline Indústria farmacèutica & 224 & 78 & 74,70 & 74,2 & 73,6 & 93,1 & 93,7 & $\begin{array}{c}< \\
0,001\end{array}$ \\
\hline Societats científiques & 168 & 58,50 & 54,20 & 56,1 & 57,2 & 69 & 71,7 & 0,031 \\
\hline $\begin{array}{l}\text { Institut Català de la } \\
\text { Salut }\end{array}$ & 165 & 57,4 & 53,3 & 57,2 & 57,4 & 58,6 & 55 & 0,790 \\
\hline
\end{tabular}

Ús de la via telemàtica: A l'AE s'utilitza significativament més la via telemàtica per al control i el seguiment de les persones amb diabetis que a l'AP (el 84,2 \% davant el 44,4 \%, respectivament, $p<0,001)$, com són l'ús del telèfon $(p=0,002)$, les plataformes de descàrregues de mesuradors $(p<0,001)$, bombes i sensors $(p<0,001)$ i programes d'educació en línia $(p<0,001)$.

En general, els professionals d'infermeria responen que dediquen a l'educació dels pacients un 63,3\% del temps (estimació ponderada del 54,53 \%). Quan se separa la mostra per àmbits d'atenció, s'observa que a l'AE el percentatge de temps dedicat a l'educació és més elevat que a l'AP (el 73,18\% davant el 53,41 \%, $p=0,004$ ) (taula 13). 
Taula 13: Temps de la jornada laboral dedicat a l'educació terapèutica dels pacients amb diabetis, per àmbit d'assistència (percentatge)

\begin{tabular}{|c|c|c|c|c|c|c|}
\multicolumn{2}{|c|}{ Total } & \multicolumn{2}{c|}{ Assistència Primària } & \multicolumn{2}{c|}{ Assistència Especialitzada } & \\
\hline $\begin{array}{c}\% \text { no } \\
\text { ponderat }\end{array}$ & $\begin{array}{c}\% \\
\text { ponderat }\end{array}$ & $\%$ no ponderat & $\begin{array}{c}\% \\
\text { ponderat }\end{array}$ & $\%$ no ponderat & $\%$ ponderat & Sig(p) \\
\hline $63,3 \%$ & $54,53 \%$ & $56,64 \%$ & $53,41 \%$ & $78 \%$ & $73,18 \%$ & 0,004 \\
\hline
\end{tabular}

\subsubsection{Indicadors de resultats}

A la taula 14 es mostren els resultats tant clínics com d'educació que els professionals d'infermeria que van respondre el qüestionari referien avaluar i registrar de forma sistemàtica, al menys un cop l'any.

Es van observar diferències significatives entre els dos àmbits d'atenció en l'avaluació de conductes de salut: activitat física (major percentatge en l'AP), monitoratge del control de glucèmia (major en l'AE), maneig de la medicació (major en l'AP) i adaptació psicosocial (major en l'AE). Per la seva banda, la tècnica d'administració de la insulina va apuntar significació estadística amb un valor de $p=0,082$ (major percentatge en l'AE). Cal destacar que 24 professionals dels 49 que van marcar l'opció «altres» es referien al fet que valoraven les conductes de salut en relació amb la cura del peu.

Respecte als resultats d'aprenentatge, cal destacar que a l'assistència especialitzada es van avaluar més i de manera significativa les habilitats tècniques (el 93,7 \% davant el 82,6\%, $p=0,037$ ), la capacitat de resolució de problemes per part del pacient (el 85,9\% davant el 57,1 \%, $p<0,001$ ), i les actituds (el 81,1\% davant el 60,9\%, $p=0,012$ ). No es van apreciar diferències significatives en la resta d'ítems, a excepció de l'apartat "altres», a favor de l'AE, però només van marcar aquesta opció 6 professionals i les respostes van ser molt variades (per exemple: avaluació de la rotació de les zones d'injecció, de la motivació per al canvi o dels resultats dels objectius pactats).

Quant als resultats clínics que s'avaluen i es registren de manera sistemàtica, es van observar diferències significatives a favor de l'atenció primària en IMC, PA, microalbuminúria, colesterol/ triglicèrids, exploració de peus, exploració oftalmològica i altres.

Els professionals, en general, avaluen poc el grau de satisfacció dels pacients envers les seves intervencions (un 32,1 \% a l'assistència primària davant el 41,3\% a l'especialitzada, $p=0,357$ ), i s'observa un percentatge major en l'àmbit de l'assistència especialitzada (el 46,6 \% davant el $31,3 \%)$, encara que les diferències no van ser estadísticament significatives $(p=0,357)$. 
Taula 14: Resultats de conductes de salut, d’aprenentage i clínics que s'avaluen i es registren de forma sistemàtica, per àmbit d'assistència

\begin{tabular}{|c|c|c|c|c|c|c|c|c|}
\hline & \multirow[b]{2}{*}{ Total } & \multirow[b]{2}{*}{$\begin{array}{c}\% \text { no } \\
\text { ponderat }\end{array}$} & \multirow[b]{2}{*}{$\begin{array}{c}\% \\
\text { ponderat }\end{array}$} & \multicolumn{2}{|c|}{$\begin{array}{l}\text { Assistència } \\
\text { Primària }\end{array}$} & \multicolumn{2}{|c|}{$\begin{array}{l}\text { Assistència } \\
\text { Especialitzada }\end{array}$} & \multirow[b]{2}{*}{$\operatorname{Sig}(p)$} \\
\hline & & & & $\begin{array}{c}\% \text { no } \\
\text { ponderat }\end{array}$ & $\begin{array}{c}\% \\
\text { ponderat }\end{array}$ & $\begin{array}{c}\% \text { no } \\
\text { ponderat }\end{array}$ & $\begin{array}{c}\% \\
\text { ponderat }\end{array}$ & \\
\hline \multicolumn{9}{|l|}{ Conductes de salut } \\
\hline Alimentació & 286 & 100 & 100 & 100 & 100 & 100 & 100 & 1,000 \\
\hline Activitat física & 284 & 99,30 & 99,80 & 100 & 100 & 96,50 & 96,90 & $\begin{array}{c}< \\
0,001\end{array}$ \\
\hline Monitor. glucèmia & 277 & 96,80 & 96,30 & 96,40 & 96,20 & 98,20 & 98,40 & 0,405 \\
\hline $\begin{array}{l}\text { Monitor. cetonèmia/ } \\
\text { úria }\end{array}$ & 132 & 46 & 38,80 & 40,30 & 37,30 & 69 & 69,4 & 0,005 \\
\hline Tècnica adm. insulina & 267 & 93,30 & 92,50 & 92,10 & 92,20 & 98,20 & 98,40 & 0,082 \\
\hline Maneig medicació & 279 & 97,50 & 98 & 98,20 & 98,60 & 94,80 & 88 & 0,003 \\
\hline $\begin{array}{l}\text { Prev./resol. complic. } \\
\text { agud }\end{array}$ & 274 & 95,80 & 96,20 & 95,60 & 96,20 & 96,50 & 96,90 & 0,829 \\
\hline Prev. FRCV & 276 & 96,50 & 96,70 & 97,30 & 96,90 & 93,10 & 93,70 & 0,319 \\
\hline Adaptació psicosocial & 162 & 56,50 & 50,20 & 50,40 & 48,30 & 81 & 82,70 & $<0,001$ \\
\hline Altres & 49 & 17 & 14,90 & 14,40 & 14,30 & 27,50 & 25,10 & 0,063 \\
\hline \multicolumn{9}{|l|}{ Aprenentatge } \\
\hline $\begin{array}{l}\text { Nivell de } \\
\text { coneixements }\end{array}$ & 246 & 86 & 86 & 85 & 83,80 & 89,60 & 90,60 & 0,179 \\
\hline Habilitats tècniques & 244 & 85,30 & 85,30 & 83,30 & 82,60 & 93,10 & 93,70 & 0,037 \\
\hline $\begin{array}{l}\text { Resolució de } \\
\text { problemes }\end{array}$ & 186 & 65 & 65 & 60 & 57,10 & 84,40 & 85,90 & $<0,001$ \\
\hline $\begin{array}{l}\text { Adherència al } \\
\text { tractament }\end{array}$ & 269 & 94 & 94 & 94,20 & 93,70 & 93,10 & 93,70 & 0,995 \\
\hline Qualitat de vida & 155 & 54 & 54 & 53 & 51 & 58,60 & 60,70 & 0,288 \\
\hline Actituds & 187 & 65,30 & 65,30 & 61,40 & 60,90 & 81 & 81,10 & 0,012 \\
\hline Cap & 10 & 3,40 & 3,40 & 3 & 4,80 & 5,10 & 4,70 & 0,986 \\
\hline Altres & 6 & 2 & 2 & 0,40 & 0,50 & 8,60 & 7,90 & $\begin{array}{c}< \\
0,001\end{array}$ \\
\hline
\end{tabular}




\begin{tabular}{|l|c|c|c|c|c|c|c|c|}
\hline Indicadors clínics & 268 & 93,70 & 93,40 & 94,20 & 93,50 & 91,30 & 92,10 & 0,725 \\
\hline HbA1c & 276 & 96,50 & 98 & 98,20 & 98,50 & 89,60 & 90,60 & 0,012 \\
\hline IMC & 281 & 98,20 & 98,40 & 99,10 & 98,60 & 94,80 & 95,30 & 0,172 \\
\hline Pes & 272 & 95 & 97,60 & 98,20 & 98,50 & 82,70 & 84,30 & 0,001 \\
\hline PA & 189 & 66 & 72,40 & 75,40 & 78,70 & 29,30 & 34 & 0 \\
\hline Microalbuminúria & 223 & 78 & 84,40 & 86,40 & 86,50 & 44,80 & 42,10 & 0,001 \\
\hline Colesterol /Triglicèrids & 248 & 86,70 & 96 & 95,60 & 98,30 & 51,70 & 54,40 & 0,001 \\
\hline Exploració de peus & 197 & 68,80 & 78,20 & 79,30 & 81,40 & 27,50 & 25,10 & 0,001 \\
\hline $\begin{array}{l}\text { Exploració } \\
\text { oftalmològica }\end{array}$ & 1 & 0,30 & 0 & 0 & 0 & 1,70 & 1,60 & 0 \\
\hline Cap & 28 & 9,70 & 11,30 & 11,40 & 11,80 & 3,40 & 3,10 & 0,040 \\
\hline Altres & $97 \%$ & 34 & 31,70 & 32,60 & 31,30 & 43,10 & 46,60 & 0,357 \\
\hline $\begin{array}{l}\text { Avaluació sistemàtica } \\
\text { del grau de satisfacció } \\
\text { dels pacients }\end{array}$ & 9 & & & & & & 0 \\
\hline
\end{tabular}

\subsubsection{Investigació}

Tot i que la investigació està poc desenvolupada en ambdós àmbits, hi ha una clara diferència en la producció científica pel que fa a publicacions, que és molt més elevada en l'atenció especialitzada que en la primària (el $34,4 \%$ davant el 9,2 \%, respectivament, $p<0,001$ ) (gràfic 5).

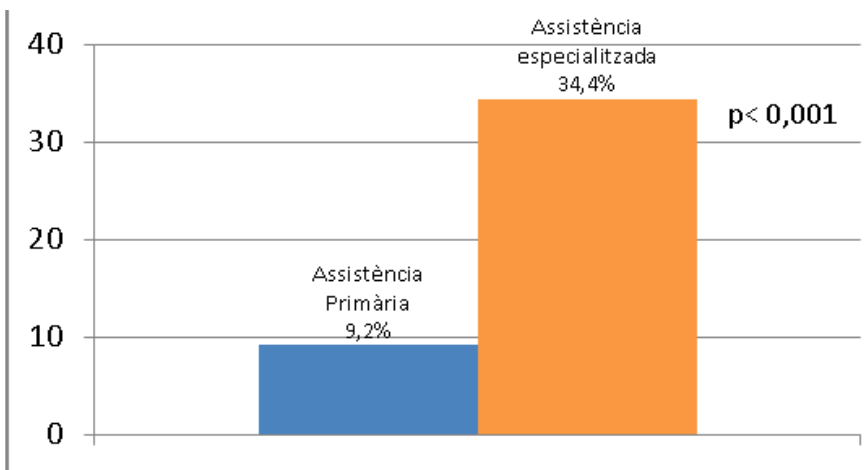

Gràfic 5: Publicacions científiques derivades de les intervencions educatives 


\subsubsection{Rols de la infermeria en l'assistència a la diabetis}

Es van comparar les competències de cadascun dels rols entre els professionals d'infermeria de l'AP i de l'AE. A continuació es detallen els resultats de cadascun dels rols avaluats:

\section{a) Rol de pràctica clínica}

Com mostra el gràfic 6, a l'AE hi ha una major relació entre els membres de l'equip per planificar, implementar i avaluar programes d'atenció a la diabetis, aplicació de les noves tecnologies en el tractament (infusió subcutània contínua d'insulina i monitoratge contínua de la glucosa) i en el seguiment, com és el consell i el suport telemàtic $(p<0,001)$. També hi ha una participació més elevada en conferències interdisciplinàries i en el fet de ser professional referent de la patologia per a altres professionals, estudiants o fins i tot de suport per al mateix pacient $(p<0,001)$. L'atenció domiciliària i la sol-licitud de proves analítiques es relaciona de forma significativa amb l'AP $(p<0,001)$. No hi ha diferències significatives entre l'AP i l'AE pel que fa a la capacitat d'ajustar el tractament farmacològic per a la diabetis, en la prescripció de medicació ni en la capacitat d'establir objectius amb el pacient, així com tampoc a l'hora de disposar d'una línea de 24 hores per a casos d'urgència $(p=0,750)$; destaca la baixa puntuació en aquest últim aspecte en ambdós àmbits d'assistència.

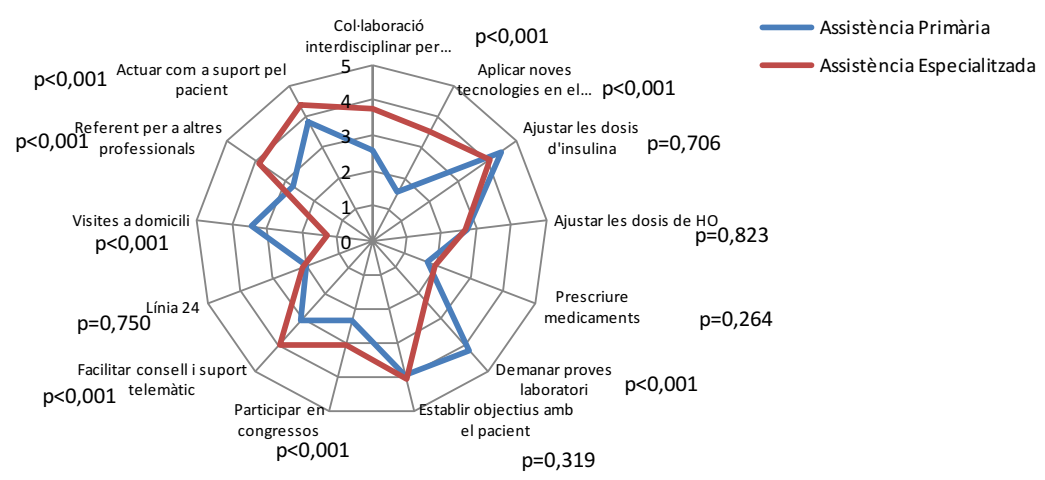

Gràfic 6: Rol de pràctica clínica

\section{b) Rol educador}

Les competències que formen part del rol educador de la infermera es poden dividir en dos grups: aquelles relacionades amb l'educació del pacient, la família i la comunitat (gràfic 7), i les relacionades amb l'educació d'altres professionals (gràfic 8). Com es pot veure en els gràfics, el rol educador, en totes les seves competències, està de manera estadísticament significativa més present a l'atenció especialitzada. 


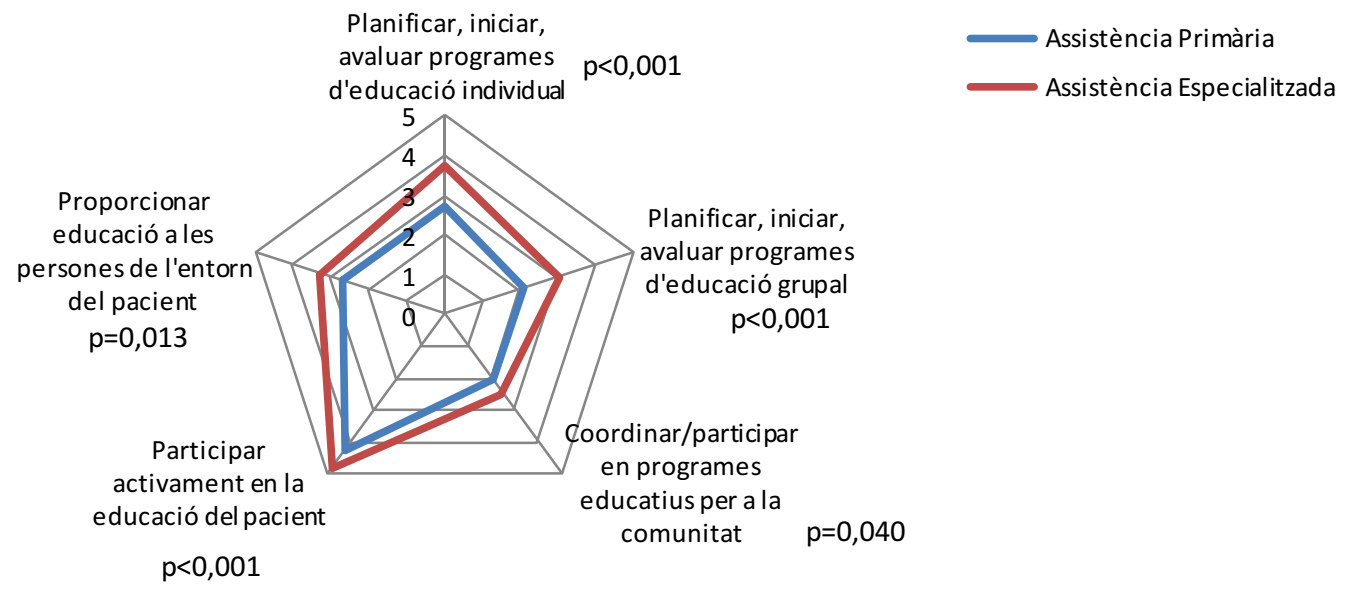

Gràfic 7: Rol educador (pacients, famílies i públic en general)

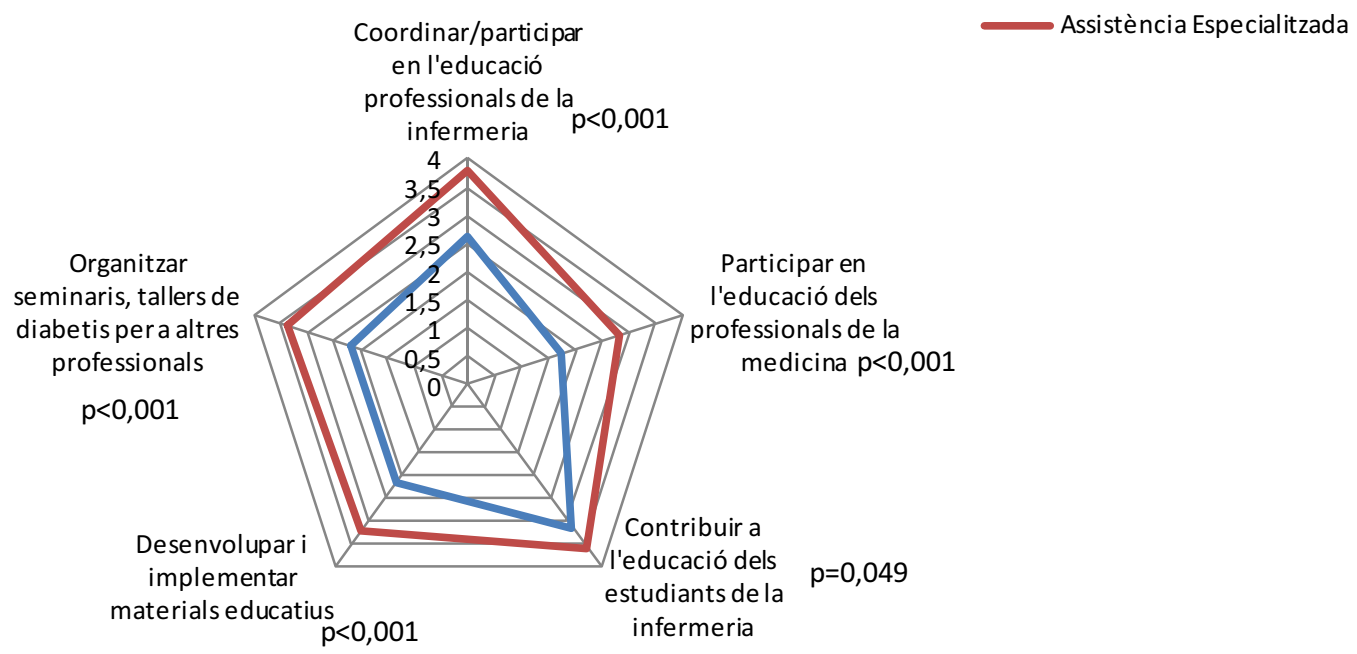

Gràfic 8: Rol educador (educació a altres professionals) 


\section{c) Rol assessor o consultor}

També les competències que formen part del rol assessor es poden dividir en dos grups: aquelles en què la infermera pot assessorar la direcció del centre o l'organització per a la qual treballa en temes de necessitats formatives dels professionals, d'implementació o elaboració d'estàndards de qualitat, protocols o guies d'assistència (gràfic 9), i les relacionades amb el fet d'assessorar altres professionals, el pacient i la família (gràfic 10). Els resultats indiquen que el rol assessor, en totes les seves competències, està significativament més present en els professionals de l'assistència especialitzada.

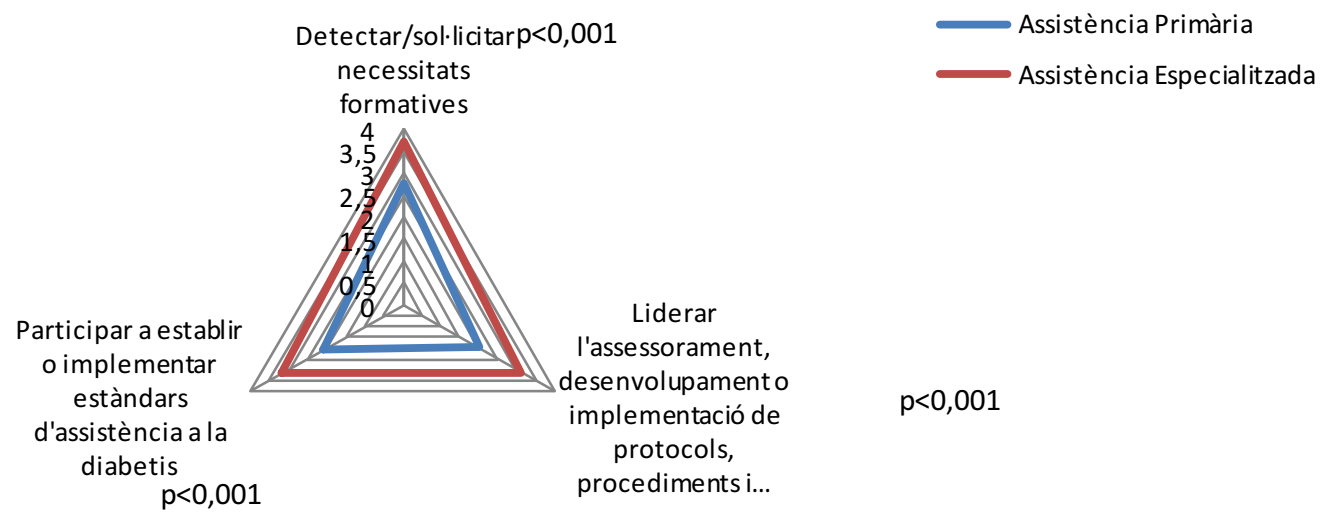

Gràfic 9: Rol assessor o consultor (en relació amb l'organització)

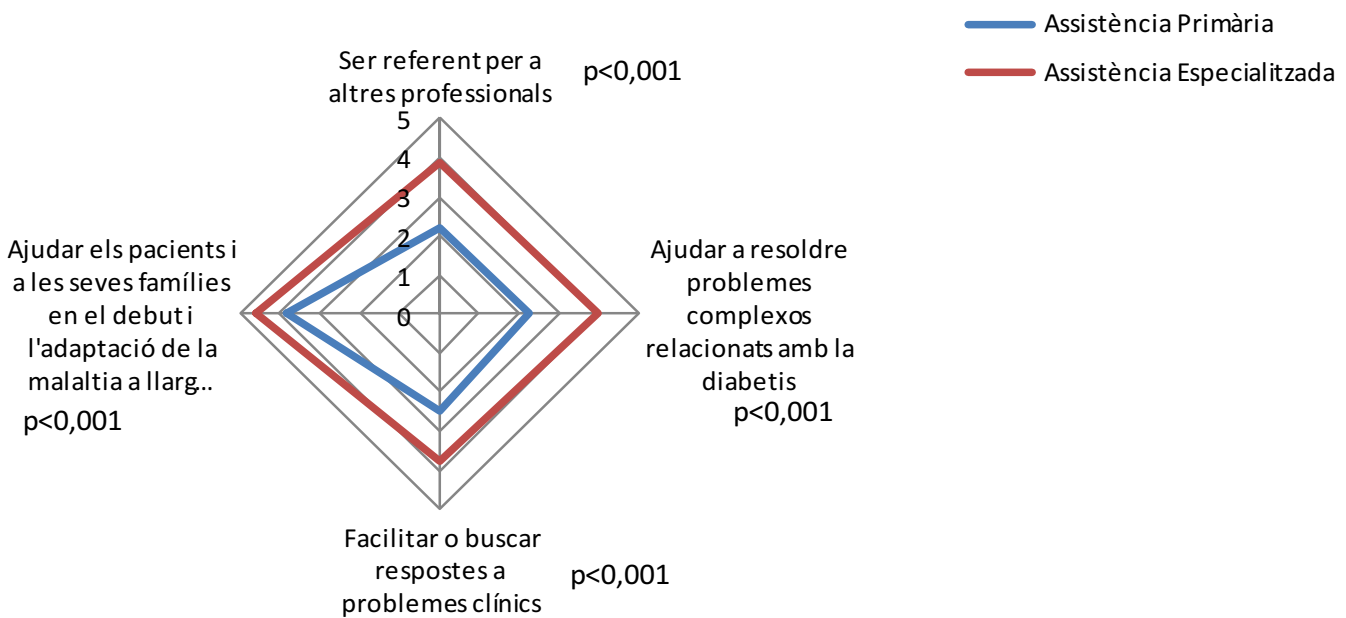

Gràfic 10: Rol assessor o consultor (en relació amb els professionals, pacients i família) 


\section{d) Rol investigador}

La mitjana de puntuacions de totes les seves competències són baixes en ambdós nivells d'assistència, però estadísticament significatives a favor de l'AE en gairebé totes les competències que configuren aquest rol. Hi ha poca participació d'infermeria en els comitès d'investigació i, en general, no se sol-licita finançament per a projectes d'investigació (gràfic 11).

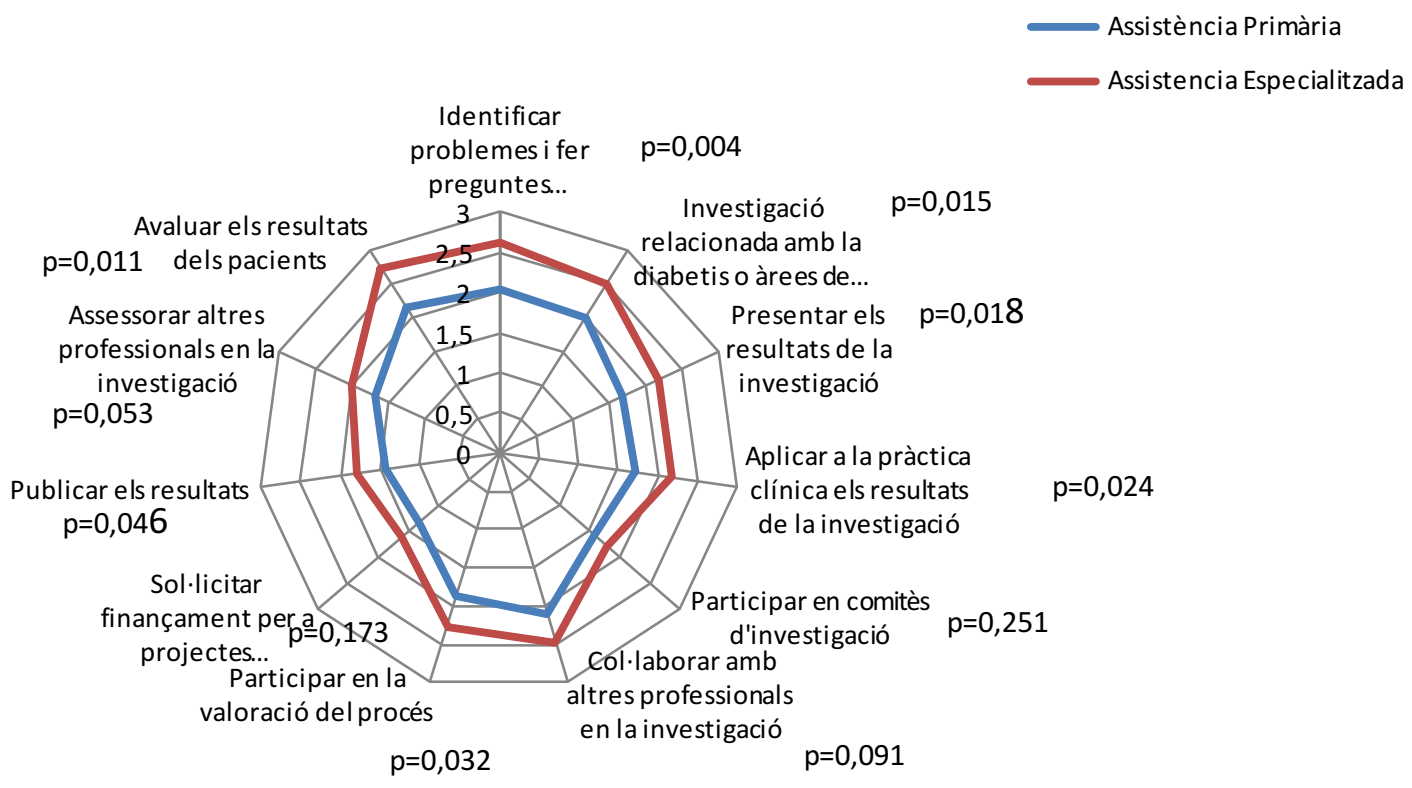

Gràfic 11: Rol investigador

\section{e) Rol director}

Tot i que el desenvolupament d'aquest rol és mol baix en els dos àmbits, les competències relacionades amb la identificació de mancances en els serveis per a l'atenció a la diabetis i la revisió de polítiques i procediments relacionats amb la diabetis van obtenir puntuacions més altes en l'AE, estadísticament significatives en comparació amb les puntuacions d'AP en el primer cas $(p<0,001)$, i apuntant significació en el segon $(p=0,063)$ respectivament (gràfic 12$)$. 


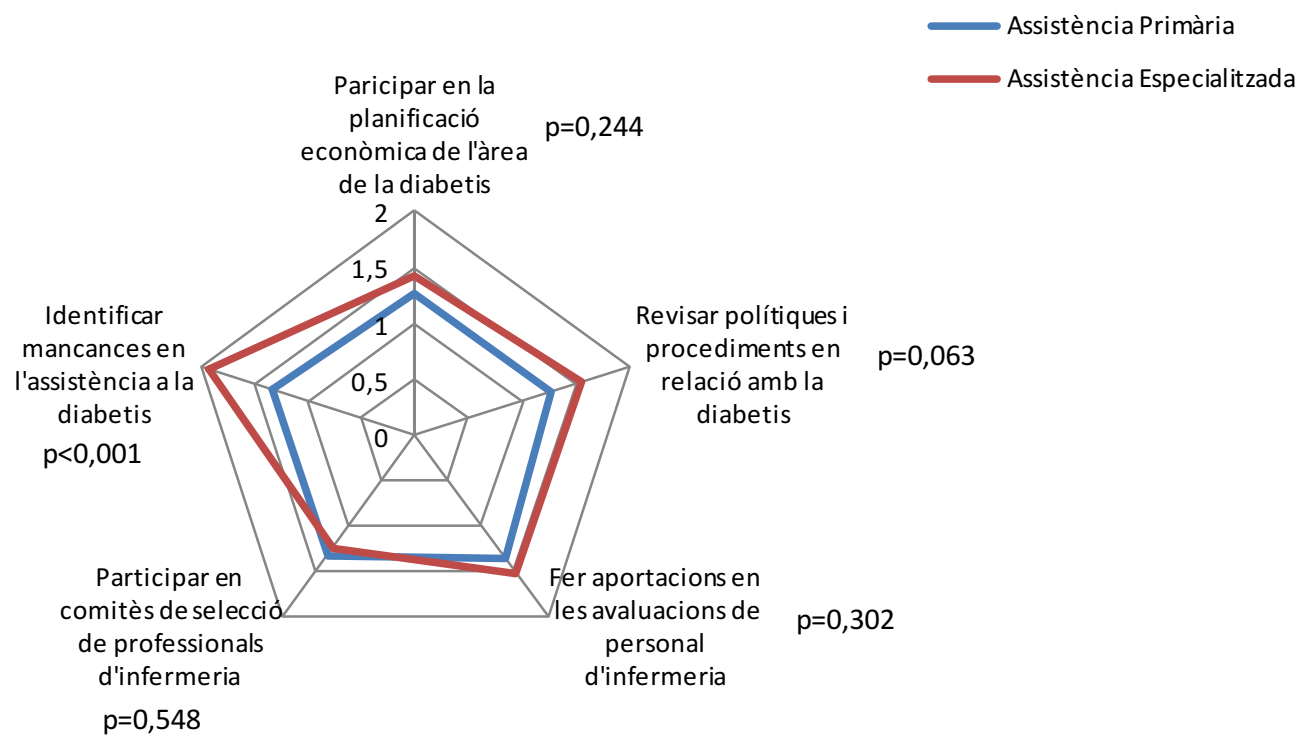

Gràfic 12: Rol director

\section{f) Rol col·laborador o d'enllaç}

De les quatre competències relacionades amb aquest rol (gràfic 13), coordinar l'alta del pacient amb els diferents nivells assistencials, dirigir o facilitar als pacients les referències per a una atenció apropiada i utilitzar o coordinar els recursos per a una atenció adequada de la diabetis mostren resultats estadísticament significatius a favor de l'AE $(p=0,018, p<0,001$ i $p=0,070$, respectivament).

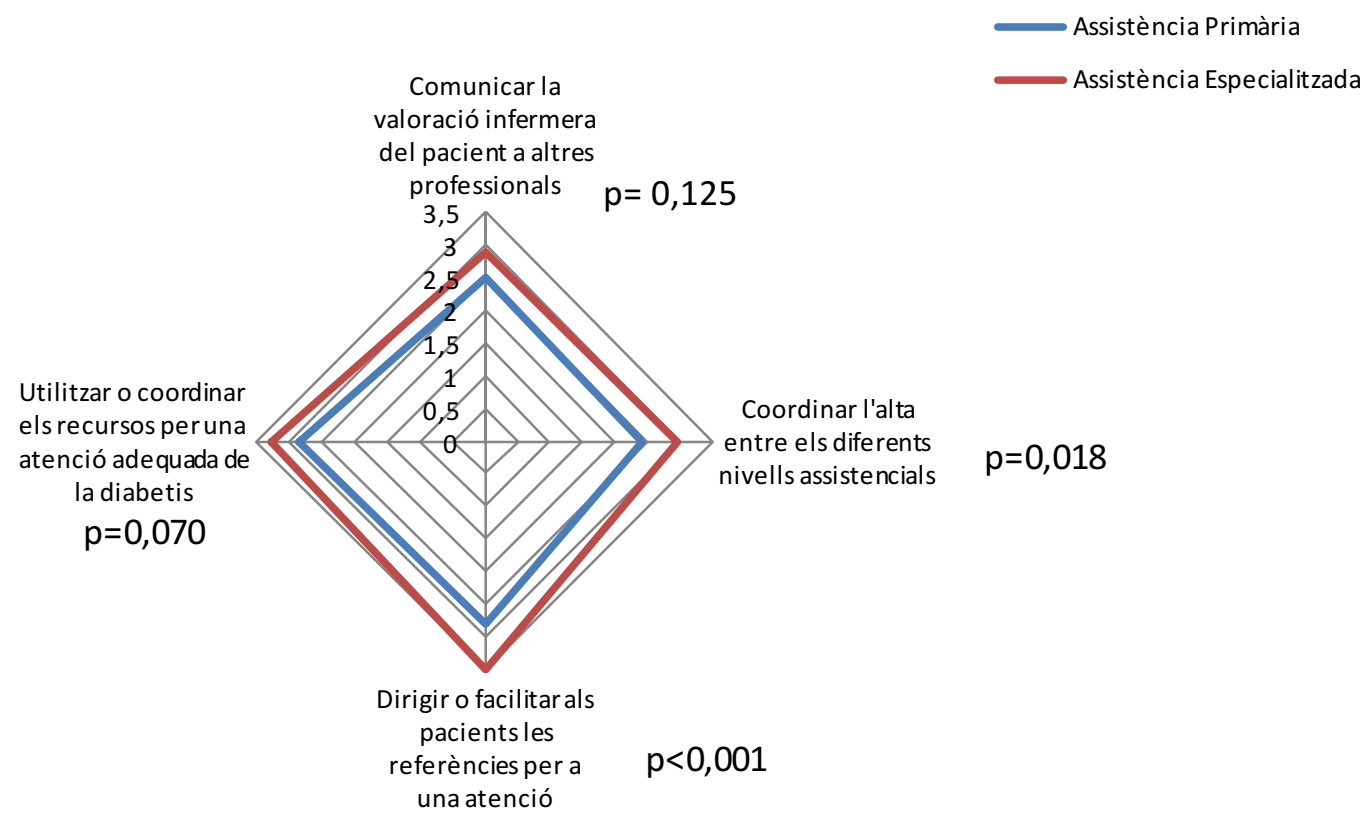

Gràfic 13: Rol col·laborador-enllaç 


\section{g) Rol innovador}

Totes les competències relacionades amb el rol innovador van ser estadísticament significatives a favor de l'atenció especialitzada (gràfic 14).

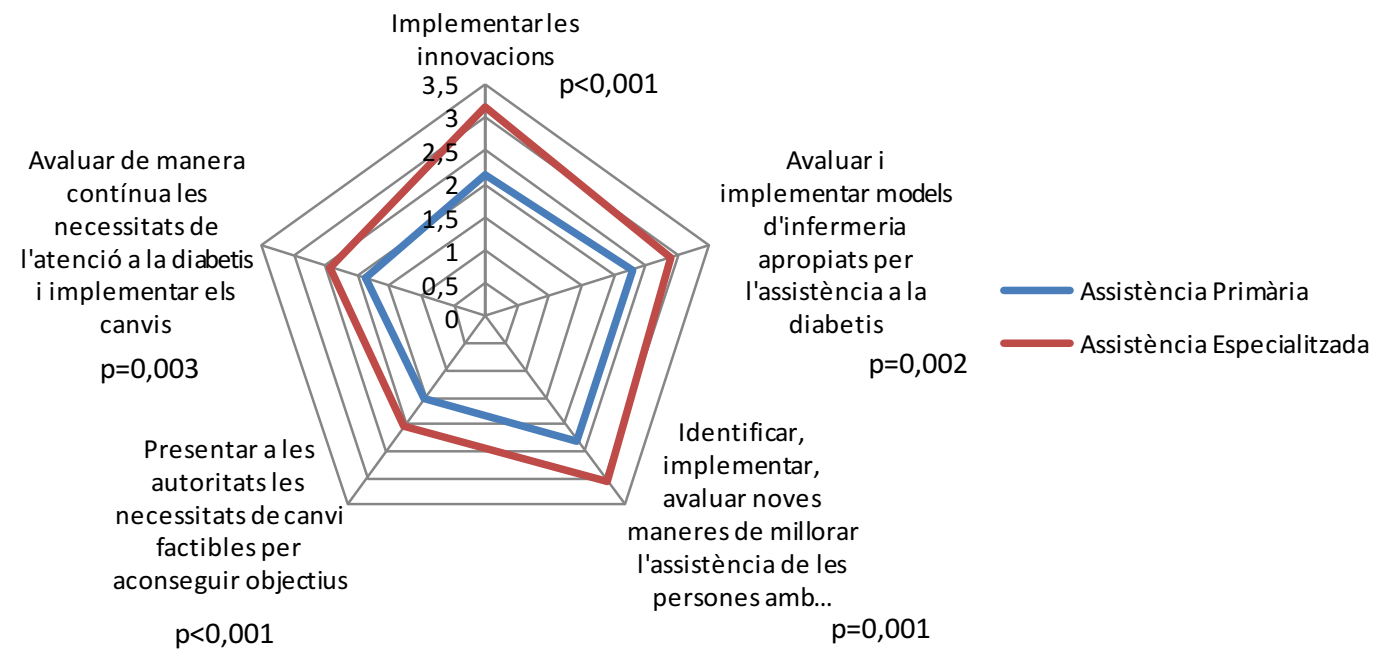

Gràfic 14: Rol innovador

\subsubsection{Grau de satisfacció personal respecte del treball que desenvolupa}

En general, els professionals mostren un alt grau de satisfacció personal relacionat amb la feina, específicament amb el respecte que reben dels pacients (puntuació mitjana a l'escala de Likert de 4,3 a l'AP, davant el 4,4 a l'AE), així com amb la relació que s'estableix entre els companys (puntuació mitjana a l'escala de Likert de 4,3 a l'AP, davant el 4,1 a l'AE), sense diferències significatives entre ambdós àmbits d'atenció. $A$ l'AE es mostra més satisfacció amb la possibilitat de consultar amb l'especialista, i a l'AP hi ha més satisfacció amb la possibilitat de consultar amb el metge de família. A l'AP també hi ha més satisfacció quant a l'organització de l'atenció $(p=0,004)$, i a l'AE amb el temps que es pot dedicar al pacient $(p=0,034)$. El pitjor grau de satisfacció en ambdós àmbits està relacionat amb el salari (puntuació mitjana a l'escala de Likert de 2,71 a l'AP i de 2,35 a l'AE), i que és estadísticament significatiu a l'AE ( $p=0,017)$. 


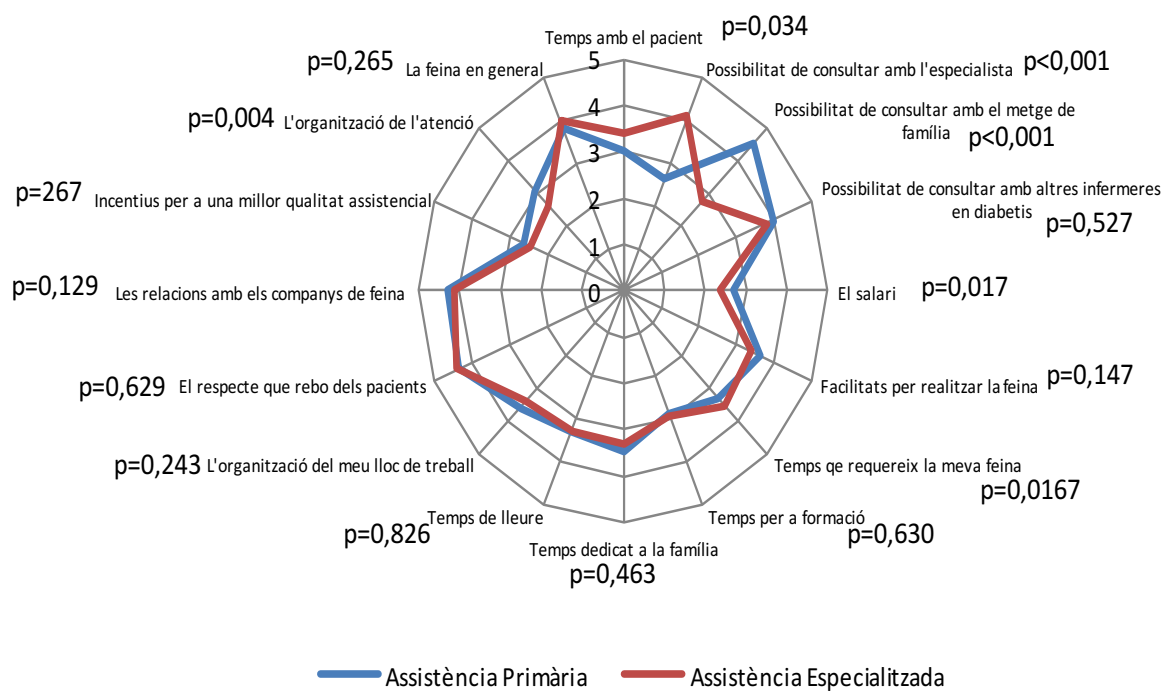

Gràfic 15. Grau de satisfacció personal en relació amb la feina

\subsubsection{Anàlisi multivariant}

En una primera fase es va realitzar una anàlisi bivariant per a l'estudi de les relacions de les variables d'interès mitjançant la construcció de models de regressió logística univariant i regressió lineal simple. Per valorar els efectes ajustats es van construir models de regressió logística i de regressió lineal multivariants en dues etapes. En la primera etapa es van incloure les variables: edat, anys d'experiència en diabetis, formació en diabetis i disposar d'aula de formació. En una segona fase es van afegir a les anteriors les variables següents: hores de formació acreditada i àmbit assistencial (primària/especialitzada). L'anàlisi bivariant va evidenciar una associació significativa entre l'educació grupal o combinada, els anys d'experiència en diabetis, disposar d'aula de formació, hores de formació acreditada i treballar en atenció especialitzada. Així mateix, va estar molt a prop de la significació estadística l'associació amb els anys de formació en diabetis $(p<0,001)$. Tenir més anys d'experiència en diabetis, disposar d'aula específica per fer educació i més formació en diabetis tant universitària com continuada són variables que afavoreixen l'aplicació de programes amb intervencions d'educació grupal.

Quan es van ajustar els efectes en l'anàlisi multivariant, van mantenir un efecte significatiu, en una primera etapa, els anys d'experiència en diabetis, la formació en diabetis i disposar d'aula de formació. En el model final amb totes les variables, només disposar d'aula de formació es va mantenir com a significativa, a més de les hores de formació acreditada i l'àmbit assistencial. També es va observar una interacció significativa entre disposar d'aula i hores de formació acreditada, de manera que a mesura que augmenten les hores de formació acreditada, l'efecte de l'aula disminueix (taula 15). 
Taula 15. Associació entre el tipus d’educació (individual/grupal) i diferents característiques dels professionals i centres

\begin{tabular}{|c|c|c|c|c|c|c|c|}
\hline \multicolumn{2}{|l|}{ Variables explicatives } & OR & Sig & OR Ajustat $^{(1)}$ & Sig & OR Ajustat ${ }^{(2)}$ & Sig \\
\hline Edat & & 1,016 & 0,303 & & & & \\
\hline $\begin{array}{l}\text { Anys experiència en diabetis } \\
\text { (TTPD) }\end{array}$ & & 1,323 & 0,018 & 1,318 & 0,022 & & \\
\hline Formació en diabetis (F1 i 2) & Sí & 2,017 & 0,084 & 2,666 & 0,024 & & \\
\hline & No & 1 & & 1 & & & \\
\hline Tenir aula (AulaEG) & Sí & 4,514 & 0,013 & 5,758 & 0,004 & 367,96 & $<0,001$ \\
\hline & No & 1 & & 1 & & 1 & \\
\hline $\begin{array}{l}\text { Hores de formació acreditada } \\
\text { (HorForacre) }\end{array}$ & & 1,317 & 0,014 & & & 3,521 & $<0,001$ \\
\hline $\begin{array}{l}\text { Primària/especialitzada } \\
\text { (Prim_esp) }\end{array}$ & Prim & 0,447 & 0,044 & & & 0,382 & 0,062 \\
\hline & Espec & 1 & & & & 1 & \\
\hline AulaEG*Horforacre & & & & & & 0,349 & 0,013 \\
\hline
\end{tabular}

Categoria de referència: Només individual. ${ }^{(1)}$ Variables explicatives: Edat, TTPD, F1 i 2, AulaEG. ${ }^{(2)}$ Variables explicatives: Edat, TTPD, F1 i 2, AulaEG, HorForacre, Prim_esp

Treballar en l'AE i tenir més hores de formació acreditada en diabetis són les variables que es van associar a una major utilització de la via telemàtica per a l'educació i el seguiment dels pacients amb diabetis. En ajustar els efectes en l'anàlisi multivariant, cap de les variables incloses va mostrar efectes significatius en la primera etapa (coincidint amb el que es va trobar en l'anàlisi bivariant). En el model final, l'efecte de la variable relacionada amb l'àmbit d'atenció es va mantenir significatiu, i el de les hores de formació acreditada va fregar la significació estadística $(p=0,066)$ (taula 16). 
Taula 16. Associació entre la utilització de la via telemàtica per a l'educació dels pacients i diferents característiques dels professionals i centres

\begin{tabular}{|c|c|c|c|c|c|c|c|}
\hline \multicolumn{2}{|l|}{ Variables explicatives } & OR & Sig & OR Ajustat ${ }^{(1)}$ & Sig & OR Ajustat ${ }^{(2)}$ & Sig \\
\hline \multirow{4}{*}{$\begin{array}{l}\text { Edat } \\
\text { Anys experiència en } \\
\text { diabetis (TTPD) } \\
\text { Formació en diabetis (F1 } \\
\text { i 2) }\end{array}$} & & 0,997 & 0,861 & & & & \\
\hline & & 1,105 & 0,425 & & & & \\
\hline & Sí & 1,21 & 0,628 & & & & \\
\hline & No & 1 & & & & & \\
\hline \multirow[t]{2}{*}{ Tenir aula (AulaEG) } & Sí & 1,969 & 0,162 & & & & \\
\hline & No & 1 & & & & & \\
\hline \multirow{3}{*}{\multicolumn{2}{|c|}{$\begin{array}{l}\text { Hores de formació acreditada } \\
\text { (HorForacre) } \\
\text { Primària/especialitzada } \\
\begin{array}{l}\text { (Prim_esp) } \\
\end{array}\end{array}$}} & 1,262 & 0,026 & & & 1,217 & 0,066 \\
\hline & & 0,149 & $<0,001$ & & & 0,214 & 0,001 \\
\hline & & 1 & & & & 1 & \\
\hline
\end{tabular}

Categoria de referència: No us. ${ }^{(1)}$ Variables explicatives: Edat, TTPD, F1 I 2, AulaEG. ${ }^{(2)}$ Variables explicatives: Edat, TTPD, F1 i 2, AulaEG, HorForacre, Prim_esp

A més, l'ús del telèfon s'associa a treballar a l'AE $(p<0,001)$ i a les hores de formació acreditada $(p=0,026)$. En el model final ajustat, només l'àmbit d'atenció es va mostrar significatiu ( $p=0,005)$ (taula 17).

Tabla 17. Associació entre la utilització de la via telefònica per al control i seguiment dels pacients i diferents característiques dels professionals i centres

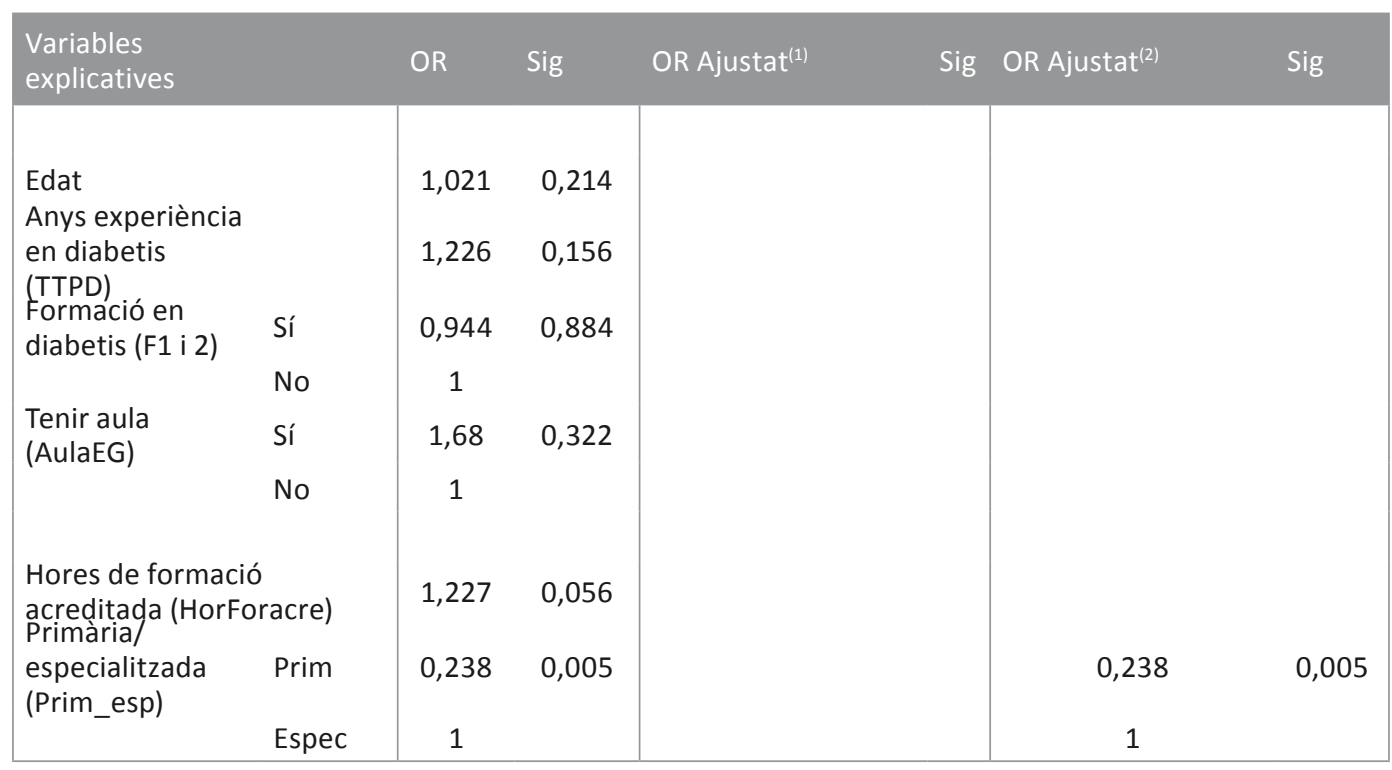

Categoria de referència: No us. ${ }^{(1)}$ Variables explicatives: Edat, TTPD, F1 i 2, AulaEG. ${ }^{(2)}$ Variables explicatives: Edat, TTPD, F1 i 2, AulaEG, HorForacre, Prim_esp 
Resultats similars es van obtenir pel que fa a l'estudi de l'associació entre la utilització de les plataformes de descàrregues de mesuradors per al seguiment telemàtic i les variables estudiades, de forma que treballar a l'AE es va associar significativament a una major utilització d'aquestes plataformes (taula 18).

Taula 18. Associació entre la utilització de plataformes de descàrregues de mesuradors per al control glucèmic i diferents característiques dels professionals i centres

\begin{tabular}{|c|c|c|c|c|c|c|c|}
\hline \multicolumn{2}{|c|}{ Variables explicatives } & OR & Sig & OR Ajustat ${ }^{(1)}$ & Sig & OR Ajustat ${ }^{(2)}$ & Sig \\
\hline \multicolumn{2}{|l|}{ Edat } & 0,996 & 0,833 & & & & \\
\hline \multicolumn{2}{|c|}{$\begin{array}{l}\text { Anys experiència } \\
\text { en diabetis (TTPD) }\end{array}$} & 0,864 & 0,367 & & & & \\
\hline \multirow[t]{2}{*}{$\begin{array}{l}\text { Formació en } \\
\text { diabetis (F1 i 2) }\end{array}$} & Sí & 2,045 & 0,121 & & & & \\
\hline & No & 1 & & & & & \\
\hline \multirow[t]{2}{*}{$\begin{array}{l}\text { Tenir aula } \\
\text { (AulaEG) }\end{array}$} & Sí & 0,46 & 0,251 & & & & \\
\hline & No & 1 & & & & & \\
\hline \multicolumn{2}{|c|}{$\begin{array}{l}\text { Hores de formació acreditada } \\
\text { (HorForacre) }\end{array}$} & 1,496 & 0,018 & & & & \\
\hline \multirow{2}{*}{$\begin{array}{l}\text { Primària/ } \\
\text { especialitzada } \\
\text { (Prim_esp) }\end{array}$} & Prim & 0,059 & $<0,001$ & & & 0,059 & $<0,001$ \\
\hline & Espec & 1 & & & & 1 & \\
\hline
\end{tabular}

Categoria de referència: No us. ${ }^{(1)}$ Variables explicatives: Edat, TTPD, F1 i 2, AulaEG. ${ }^{(2)}$ Variables explicatives: Edat, TTPD, F1 i 2, AulaEG, HorForacre, Prim_esp

La utilització de descàrregues de bombes i sensors es va associar a una major formació acadèmica en diabetis (màster o postgrau), més hores de formació acreditada i treballar a l'AE (efectes crus o simples que provenen de l'anàlisi bivariant). Després d'ajustar el model en una primera etapa, a més de la formació en diabetis, l'edat i els anys d'experiència en diabetis van arribar a la significació estadística, de forma que es detecta una major utilització d'aquestes plataformes a mesura que puja l'edat, com menys anys d'experiència es té en diabetis i com més formació en diabetis es rep. En el model final els efectes d'aquestes dues variables van perdre la significació, i es van mantenir en el model ajustat la formació en diabetis, les hores de formació acreditada i l'àmbit d'atenció, per bé que es van detectar interaccions significatives entre l'àmbit d'atenció i la formació en diabetis i les hores de formació acreditada, de manera que la utilització augmentava si també ho feien les hores de formació acreditada. Hi ha una major utilització si es treballa en AE en comparació AP, cosa que s'accentua encara més com més hores de formació acreditada es tenen (taula 19). 
Taula 19. Associació entre la utilització de plataformes de descàrrega de bombes i sensors i diferents característiques dels professionals i centres

\begin{tabular}{|c|c|c|c|c|c|c|c|}
\hline \multicolumn{2}{|c|}{ Variables explicatives } & OR & Sig & OR Ajustat ${ }^{(1)}$ & Sig & OR Ajustat ${ }^{(2)}$ & Sig \\
\hline \multicolumn{2}{|l|}{ Edat } & 1,035 & 0,195 & 1,076 & 0,023 & & \\
\hline \multicolumn{2}{|c|}{$\begin{array}{l}\text { Anys experiència en } \\
\text { diabetis (TTPD) }\end{array}$} & 0,911 & 0,511 & 0,624 & 0,008 & & \\
\hline \multirow[t]{2}{*}{$\begin{array}{l}\text { Formació en } \\
\text { diabetis (F1 i 2) }\end{array}$} & Sí & 6,217 & $<0,001$ & 8,034 & $<0,001$ & 0,168 & 0,032 \\
\hline & No & 1 & & 1 & & 1 & \\
\hline \multirow[t]{2}{*}{$\begin{array}{l}\text { Tenir aula } \\
\text { (AulaEG) }\end{array}$} & Sí & 0,888 & 0,865 & & & & \\
\hline & No & 1 & & & & & \\
\hline \multicolumn{2}{|c|}{$\begin{array}{l}\text { Hores de formació acreditada } \\
\text { (HorForacre) }\end{array}$} & 2,532 & $<0,001$ & & & 2,729 & 0,04 \\
\hline \multirow{2}{*}{$\begin{array}{l}\text { Primària/ } \\
\text { especialitzada } \\
\text { (Prim_esp) }\end{array}$} & Prim & 0,014 & $<0,001$ & & & 0,168 & 0,836 \\
\hline & Espec & 1 & & & & 1 & \\
\hline & $\begin{array}{l}\text { [FU1 i } 2 \text { *Prima_ } \\
\text { espe }\end{array}$ & & & & & 72,827 & $<0,001$ \\
\hline & $\begin{array}{l}\text { [Prima_espec * } \\
\text { HoForAcre }\end{array}$ & & & & & 0,321 & 0,007 \\
\hline
\end{tabular}

Categoria de referència: No us. ${ }^{(1)}$ Variables explicatives: Edat, TTPD, F1 i 2, AulaEG. ${ }^{(2)}$ Variables explicatives: Edat, TTPD, F1 i 2, AulaEG, HorForacre, Prim_esp

Respecte a l'ús de mitjans telemàtics per a l'educació de pacients, s'observa que treballar a I'AE i tenir més hores de formació acreditada en diabetis s'associen a una major utilització dels programes educatius en línia (efectes crus o simples). En el model final ajustat, a més de l'àmbit d'atenció (major utilització en AE) es va detectar com a significatiu disposar d'aula d'educació (tenir una aula per fer educació incrementava la utilització d’aquests tipus de mitjans). Cal destacar que l'efecte de les hores de formació acreditada va fregar la significació estadística ( $p=0,079)$ (taula 20). 
Taula 20. Associació entre la utilització de programes educatius en línia i diferents característiques dels professionals i centres

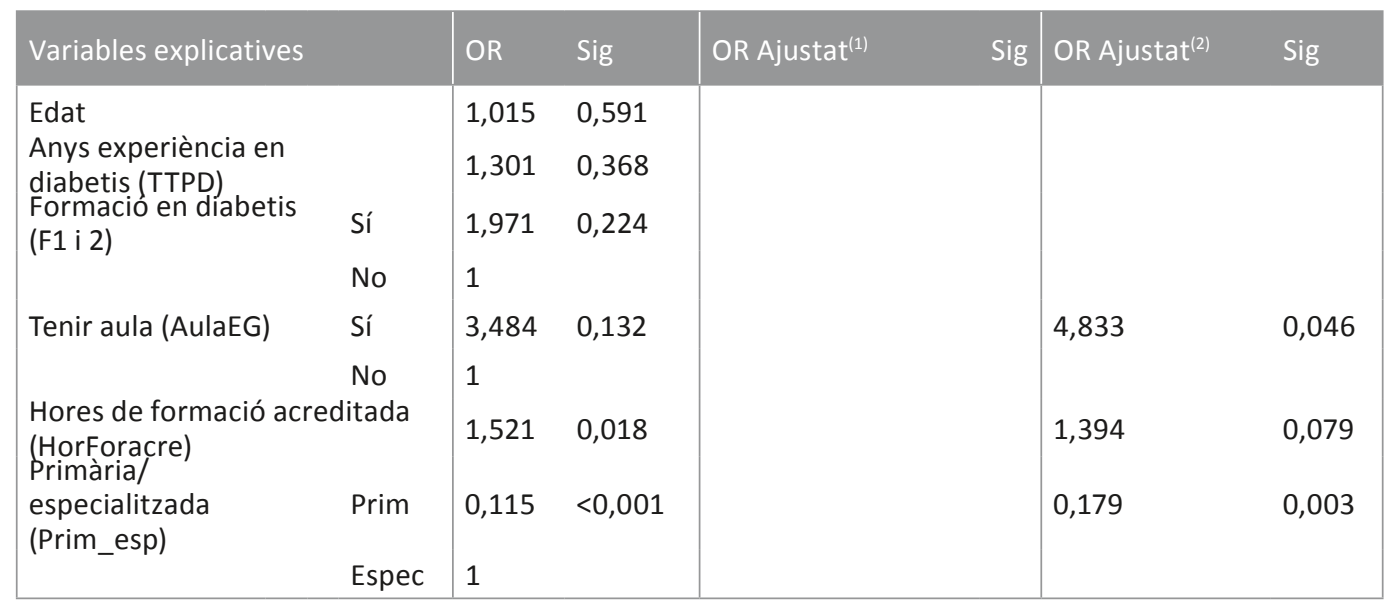

Categoria de referència: No us. ${ }^{(1)}$ Variables explicatives: Edat, TTPD, F1 i 2, AulaEG. ${ }^{(2)}$ Variables explicatives: Edat, TTPD, F1 i 2, AulaEG, HorForacre, Prim_esp

La utilització d'altres vies, com és el correu electrònic, per al seguiment i la comunicació amb els pacients es va associar únicament amb l'edat en l'anàlisi bivariant: a mesura que puja l'edat, menys s'utilitza aquest tipus de seguiment. Després de la inclusió de les variables corresponents a la primera etapa, es va detectar un efecte d'interacció significatiu entre l'edat i la formació en diabetis, ja que es va evidenciar una major utilització relacionada amb una major l'edat si es té formació en diabetis, i un ús menor relacionat amb una major edat si no se'n té. En el model final amb totes les variables, només es va detectar l'edat (en el mateix sentit que en l'anàlisi bivariant) i l'àmbit d'assistència (major utilització en l'AE) (taula 21).

Taula 21. Associació entre la utilització d'altres vies per al seguiment i la comunicació amb els pacients i diferents característiques dels professionals i centres

\begin{tabular}{|c|c|c|c|c|c|c|}
\hline Variables explicatives & OR & Sig & OR Ajustat ${ }^{(1)}$ & Sig & OR Ajustat ${ }^{(2)}$ & Sig \\
\hline \multirow{2}{*}{$\begin{array}{l}\text { Edat } \\
\text { Anys experiència en } \\
\text { diabetis (TTPD) } \\
\text { Formacio en diabetis }\end{array}$} & 0,936 & 0,031 & 0,888 & 0,422 & 0,928 & 0,015 \\
\hline & 0,817 & 0,163 & & & & \\
\hline (F1 i 2) & $\begin{array}{c}1,547 \\
1\end{array}$ & 0,525 & $\begin{array}{c}0,001 \\
1\end{array}$ & 0,025 & & \\
\hline \multirow{2}{*}{$\begin{array}{l}\text { Tenir aula (AulaEG) Sí } \\
\\
\text { Hores de formació acreditada } \\
\text { (HorForacre) } \\
\text { Primària/ } \\
\text { especialitzada }\end{array}$} & 0,378 & 0,311 & & & & \\
\hline & $\begin{array}{c}1 \\
1,093\end{array}$ & 0,645 & & & & \\
\hline $\begin{array}{l}\text { Prim } \\
\text { Espec }\end{array}$ & $\begin{array}{c}0,402 \\
1\end{array}$ & 0,126 & & & $\begin{array}{c}0,249 \\
1\end{array}$ & 0,023 \\
\hline $\begin{array}{l}{[\mathrm{FU1y2}=1,00]} \\
{ }^{*} \text { Edat }\end{array}$ & & & 1,201 & 0,008 & & \\
\hline
\end{tabular}

Categoria de referència: No ús. (1)Variables explicatives: Edat, TTPD, F1 i 2, AulaEG. (2)Variables explicatives: Edat, TTPD, F1 i 2, AulaEG, HorForacre, Prim_esp 
Respecte a la capacitat investigadora dins el camp de l'educació terapèutica en diabetis, es va observar que treballar a l'AE, més formació universitària en diabetis, més anys d'experiència en diabetis i disposar d'una aula especifica per fer-hi educació es van associar significativament a la capacitat de divulgació científica pel que fa a publicacions (resultats de l'anàlisi bivariant). Atès que influeixen totes les variables en el model final, totes les variables anteriors van mantenir efectes significatius, a excepció de les hores de formació acreditada. No es va trobar relació amb l'edat (taula 22).

Taula 22. Associació entre publicacions i diferents característiques dels professionals i centres

\begin{tabular}{|c|c|c|c|c|c|c|}
\hline Variables explicatives & OR & Sig & OR Ajustat ${ }^{(1)}$ & Sig & OR Ajustat ${ }^{(2)}$ & Sig \\
\hline Edat & 1,026 & 0,338 & & & & \\
\hline $\begin{array}{l}\text { Anys experiència en } \\
\text { diabetis (TTPD) }\end{array}$ & 1,713 & 0,045 & 1,885 & 0,0059 & 1,711 & 0,082 \\
\hline $\begin{array}{l}\text { Formació en diabetis (F1 } \\
\text { i 2) }\end{array}$ & 4,081 & 0,006 & 5,601 & 0,001 & 3,801 & 0,028 \\
\hline Tenir aula (AulaEG) & 19,638 & 0,005 & 32,763 & 0,003 & 32,276 & 0,002 \\
\hline $\begin{array}{l}\text { Hores de formació acreditada } \\
\text { (HorForacre) }\end{array}$ & 1,524 & 0,016 & & & & \\
\hline $\begin{array}{ll}\text { Primària/especializada } & \\
\text { (Prim_esp) } & \text { Prim } \\
& \text { Espec }\end{array}$ & 0,132 & $<0,001$ & & & 0,155 & 0,002 \\
\hline
\end{tabular}

Categoria de referència: No ús. ${ }^{(1)}$ Variables explicatives: Edat, TTPD, F1 i 2, AulaEG. ${ }^{(2)}$ Variables explicatives: Edat, TTPD, F1 i 2, AulaEG, HorForacre, Prim_esp

Per a l'anàlisi del grau de satisfacció es va construir una mesura global de satisfacció, resultat de sumar les puntuacions de tots els ítems. El grau de satisfacció personal global envers el treball (taula 23) no va mostrar una relació significativa en l'anàlisi bivariant amb cap de les variables considerades. Quan es va construir un primer model de regressió lineal múltiple amb les variables de la primera etapa, es va detectar una major satisfacció significativa si es tenia formació prèvia i si es disposava d'una aula d'educació. A més, es va trobar un efecte d'interacció entre aquestes dues variables, de forma que s'atenuava una mica la magnitud de l'efecte en cas de tenir les dues característiques anteriors.

En el model final multivariant amb totes les variables, es van detectar múltiples interaccions significatives que van dificultar de manera considerable la interpretació. No obstant, sembla observar-se que, com més edat, més grau de satisfacció si no es disposa d'aula d'educació. Si se'n disposa, el grau de satisfacció disminueix lleugerament amb l'edat. D'altra banda, si es tenia formació en diabetis, però no es disposava d'aula, el grau de satisfacciò es reduïa en 5,761 punts en comparació amb els que no tenien ni formació prèvia ni aula. 
Si mancava formació en diabetis però es disposava d'aula, el grau de satisfacció creixia en 17,621 punts. En canvi, si es tenia formació prèvia en diabetis i, a més, es disposava d'aula, la satisfacció disminuïa molt lleugerament, i en una magnitud no significativa (-0,262 punts).

Per acabar, com més hores de formació acreditada, més satisfacció, la qual augmentava encara més si es tenia formació en diabetis.

Taula 23. Grau de satisfacció personal dels professionals en relació amb el treball (suma de tots els ítems)

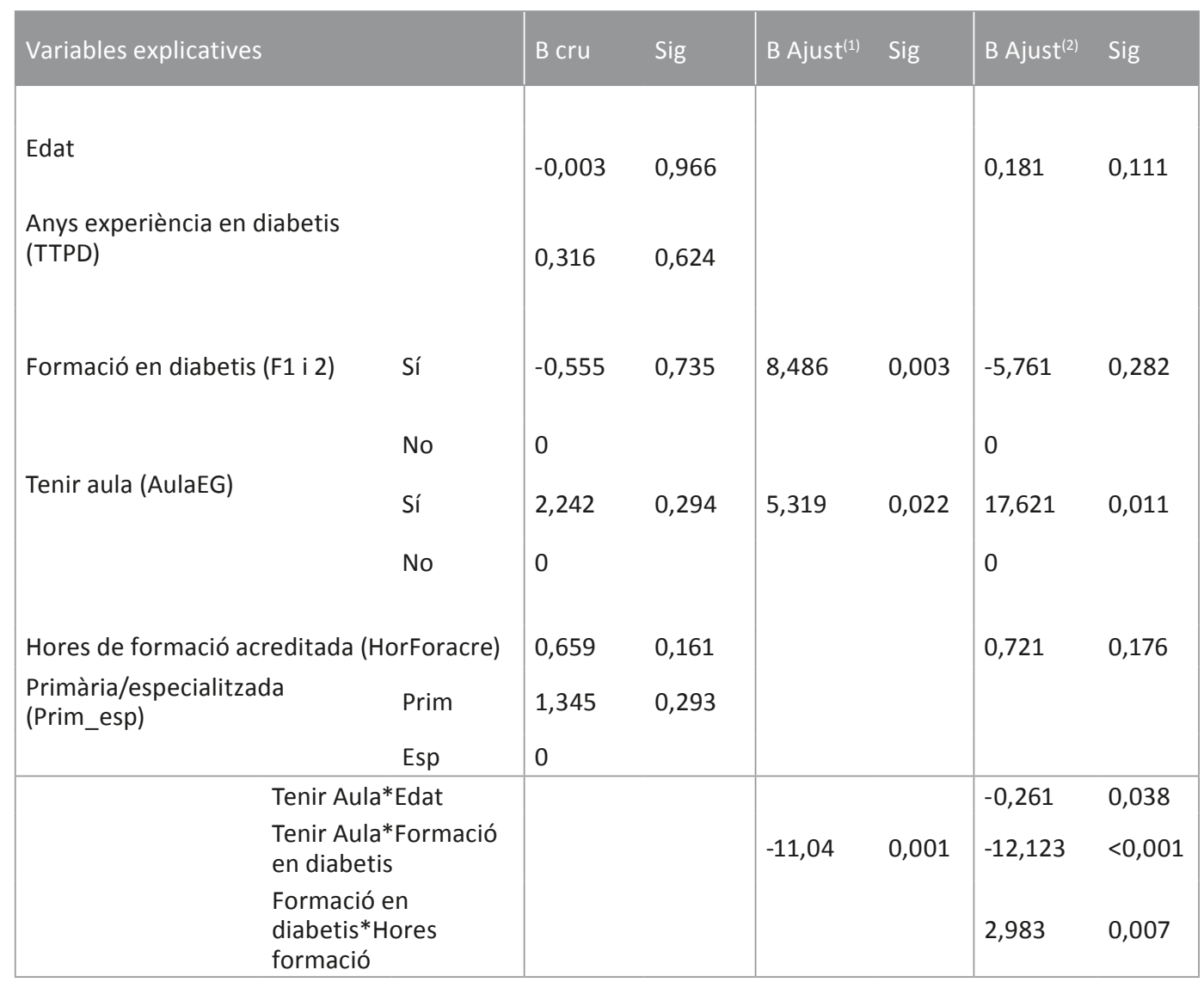

Categoria de referència: No ús. ${ }^{(1)}$ Variables explicatives: Edat, TTPD, F1 i 2, AulaEG. ${ }^{(2)}$ Variables explicatives: Edat, TTPD, F1 i 2, AulaEG, HorForacre, Prim_esp

Per tal de realitzar una anàlisi més detallada de l'associació del grau de satisfacció i diferents característiques dels professionals que permetés distingir entre diversos aspectes o dimensions de la satisfacció, es va fer una anàlisi factorial a partir dels 16 ítems del qüestionari. Es va detectar un total de 5 dimensions que van aconseguir explicar al voltant del $70 \%$ de la variació total. Aquest resultat va permetre agrupar les preguntes en les següents dimensions: 
- Dimensió 1. Agrupa les preguntes 1, 6, 7, 8, 11 i 16: satisfacció pel temps de dedicació als pacients, a la pròpia formació i a l’organització de la feina.

- Dimensió 2. Agrupa les preguntes 9 i 10: satisfacció pel temps d’oci i la dedicació a la família.

- Dimensió 3. Agrupa les preguntes 3, 12 i 13: satisfacció per la relació amb els companys, els metges de família i els pacients.

- Dimensió 4. Agrupa les preguntes 2 i 4: satisfacció per la possibilitat o facilitat de consultar amb especialistes o altres professionals experts en educació terapèutica i diabetis.

- Dimensió 5. Agrupa les preguntes 5, 14 i 15: satisfacció envers el salari, els incentius i l’organització sanitària.

A continuació, es van construir 5 noves variables de satisfacció a partir de la mitjana de les puntuacions de les preguntes corresponents a cadascuna de las dimensions. Finalment, es van construir models de regressió lineal múltiple per a l'estudi de l'associació entre les diferents dimensions de satisfacció i les variables: edat, anys d'experiència en diabetis, formació universitària en diabetis, hores de formació acreditada, disposar d'aula de formació i àmbit assistencial (primària/especialitzada).

El grau de satisfacció pel temps de dedicació als pacients, a la pròpia formació i a l'organització de la feina (dimensió 1) s'associa a la disponibilitat d'espai adient, com és disposar d'una aula per fer-hi educació. Tant en AP como en AE, si es té una aula, el grau de satisfacció augmenta, per bé que en l'AE augmenta pràcticament el doble. D'altra banda, també es va observar que tenir formació universitària en diabetis disminueix, en general, el grau de satisfacció en relació amb aquesta dimensió (taula 24), encara que aquesta disminució s'atenua si es compensa amb un increment de les hores de formació acreditada. 
Taula 24. Satisfacció pel temps de dedicació als pacients, a la pròpia formació i a l'organització de la feina

\begin{tabular}{|c|c|c|c|c|}
\hline \multirow{2}{*}{ Paràmetre } & \multirow[b]{2}{*}{ B } & \multicolumn{2}{|c|}{ Interval de confiança 95\% } & \multirow{2}{*}{ Sig. } \\
\hline & & Límit inferior & Límit superior & \\
\hline Intersecció & 3,022 & 2,699 & 3,346 & 000 \\
\hline Aula & & & & \\
\hline Sí & ,492 & 117 &, 867 & 010 \\
\hline No & 0 & . & . & . \\
\hline Primària/Especialitzada & & & & \\
\hline Primària & 190 &,- 136 &, 516 & ,253 \\
\hline Especialitzada & 0 & . & ${ }^{\circ}$ & . \\
\hline Formació universitària en diabetis & -1.092 & -1.568 & -617 & 000 \\
\hline $\begin{array}{l}\mathrm{Si} \\
\text { No }\end{array}$ & 0 & & & \\
\hline HoForAcre &, 034 &, 001 &, 066 & ,041 \\
\hline Formació Univ. Diabe*HorForAcre & ,200 & 094 & ,306 & 000 \\
\hline Aula=Sí $*$ Primària &,- 402 &,- 797 &,- 006 & , 046 \\
\hline
\end{tabular}

La satisfacció amb el temps de lleure i la dedicació a la família (dimensió 2) s’associa al nombre d'hores de formació acreditada i a la formació universitària en diabetis. S'observa que a mesura que augmenten les hores de formació acreditada, la satisfacció també creix, però disminueix si es té formació universitària en diabetis (taula 25).

Taula 25. Satisfacció amb el temps d’oci i la dedicació a la família

\begin{tabular}{|l|l|l|l|l|}
\hline Paràmetre & B & Sig. & \multicolumn{2}{|l|}{ Interval de confiança 95\% } \\
\hline $\begin{array}{l}\text { Intersecció } \\
\begin{array}{l}\text { Formació universitària en diabetis } \\
\text { Sí }\end{array}\end{array}$ & 3,031 &, 000 & 2,915 & 3,148 \\
$\begin{array}{l}\text { No } \\
\text { HoForAcre }\end{array}$ &,- 260 &, 001 &,- 411 &,- 109 \\
\hline
\end{tabular}

La satisfacció per la relació entre els companys i entre els pacients (dimensió 3) s'associa amb la formació universitària, hores de formació acreditada, disposar d'espai per fer educació (aula), l'àmbit d'atenció i l'edat. La satisfacció disminueix quan es té formació universitària; en canvi, a l'AP la satisfacció augmenta com més hores de formació acreditada es tenen. A l'AE, com més edat es té, major és la satisfacció que s'estableix entre els companys i entre els pacients, relació que també es dona si es disposa d'aula específica per fer-hi educació. En canvi, a l'AP, més edat s'associa a una menor satisfacció en aquesta dimensió (taula 26). 
Taula 26. Satisfacció per la relació amb els companys i amb els pacients

\begin{tabular}{|c|c|c|c|c|}
\hline \multirow{2}{*}{ Paràmetre } & \multirow{2}{*}{ B } & \multirow{2}{*}{ Sig. } & \multicolumn{2}{|c|}{ Interval de confiança 95\% } \\
\hline & & & Límit inferior & Límit superiol \\
\hline Intersecció & 2,870 & 000 & 2,037 & 3,703 \\
\hline \multicolumn{5}{|l|}{ Formació universitària en diabetis } \\
\hline Sí &,- 109 & 023 &,- 202 &,- 015 \\
\hline No & 0 & . & . & . \\
\hline HoForAcre &,- 122 & 139 &,- 283 & 039 \\
\hline \multicolumn{5}{|l|}{ Aula } \\
\hline Sí &, 552 & 001 & ,214 & 890 \\
\hline No & 0 & . & . & . \\
\hline \multicolumn{5}{|l|}{ Primària/Especialitzada } \\
\hline Primària & 1,572 & ,000 & ,720 & 2,424 \\
\hline Especialitzada & 0 & . & . & . \\
\hline Edat & ,017 & ,085 &,- 002 & 035 \\
\hline TTPD11 & ,038 & 024 & 005 & 072 \\
\hline Aula $=S i ́$ * Primària &,- 570 & ,001 &,- 921 &,- 219 \\
\hline Primària * HoForAcre & 179 & 030 & 017 & ,342 \\
\hline Primària * Edat &,- 025 & 010 &,- 044 &,- 006 \\
\hline
\end{tabular}

TTD11: Anys experiència atenció pacients

Pel que fa a la satisfacció per la possibilitat o facilitat de consultar amb especialistes o altres professionals experts en educació terapèutica i diabetis (dimensió 4), s’associa a l'espai específic per fer-hi educació (aula), a l'àmbit d'atenció i a les hores de formació acreditada. En general, la satisfacció es major com més hores de formació acreditada hi ha i si es disposa d'espai adient per fer-hi educació. A l’AE la satisfacció en aquesta dimensió és més elevada (taula 27).

Taula 27. Satisfacció per la possibilitat o facilitat de consultar amb especialistes o altres professionals experts en educació terapèutica i diabetis

\begin{tabular}{|c|c|c|c|c|}
\hline \multirow{2}{*}{ Paràmetre } & \multirow{2}{*}{ B } & \multirow{2}{*}{ Sig. } & \multicolumn{2}{|c|}{ Interval de confiança 95\% } \\
\hline & & & Límit inferior & Límit superiol \\
\hline Intersecció & 3,529 & ,000 & 3,240 & 3,818 \\
\hline HoForAcre & ,057 & 002 & ,021 & ,093 \\
\hline Aula & & & & \\
\hline Sí & ,295 & ,000 & 147 & ,444 \\
\hline No & 0 & . & . & . \\
\hline Primària/Especialitzada & & & & \\
\hline Primària &,- 656 & ,000 &,- 895 &,- 417 \\
\hline Especialitzada & 0 & . & . & . \\
\hline
\end{tabular}


La satisfacció relativa al salari i a l'organització sanitària (dimensió 5) s'associa a l'edat, les hores de formació acreditada, tenir espai per fer-hi educació, l'àmbit d'atenció i l'experiència en l'assistència a persones amb diabetis. S'observa una major satisfacció com més hores de formació acreditada es tenen i si es disposa d'espai específic per fer-hi educació. A l'AE, com més anys d'experiència en diabetis es tenen, menor és la satisfacció amb el salari i amb l'organització sanitària. Amb tot, a l'AP hi ha una major satisfacció en aquesta dimensió, per bé que descendeix amb l'edat (taula 28).

Taula 28. Satisfacció relativa al salari i a l’organització sanitària

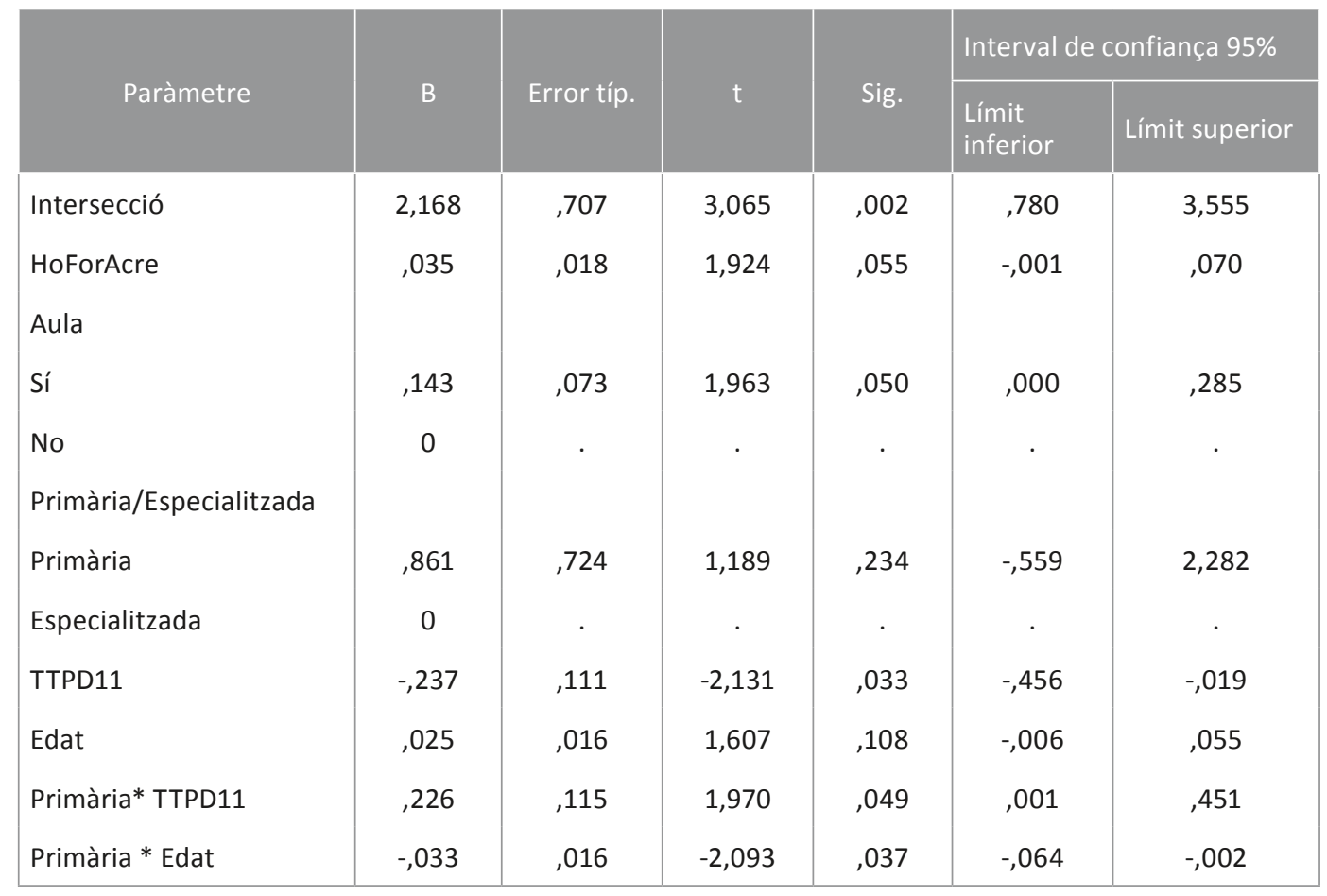

\subsubsection{Observacions i propostes de millora}

Majoritàriament, a l'AP els professionals manifesten una insatisfacció relacionada amb la falta de recursos materials i humans per fer educació grupal, tot i creure en els beneficis d'aquest mètode educatiu.

Com a propostes de millora, a l'AP es demanen més hores de formació, per a visites individualitzades i per a educació grupal. L'AE reclama unificar programes d'educació, més temps per a investigació i el reconeixement de la infermera experta en diabetis amb una acreditació acadèmica. Ambdós àmbits demanen millorar la interrelació i la coordinació entre l'AE i l'AP, així com disposar de més temps per dedicar-lo als pacients. 


\section{DISCUSSIÓ}

Els resultats d'aquest estudi mostren que l'interés per l'Educació Terapèutica en la Diabetis es va començar a desenvolupar a Catalunya a finals dels anys setanta del segle $\mathrm{xx}$, gràcies, principalment, a metges endocrinòlegs i a alguns professionals d'infermeria i dietistes de determinats hospitals que van col·laborar amb ells. Destaca el Dr. Pla, que al 1973 va iniciar a Girona les primeres colònies per a nens amb diabetis; el Dr. López Batllori, de l'Hospital de la Creu Roja de Barcelona, el qual va iniciar cicles de conferències per a persones amb diabetis, i d'una manera especial, el Dr. Figuerola, que a l'Hospital Clínic de Barcelona va iniciar un programa de formació per a professionals sanitaris i d'educació per a pacients amb diabetis, així com el Dr. Leiva, de l'Hospital de la Santa Creu i Sant Pau, molt sensibilitzat per la funció educadora de la infermera, després que fes una estada a la clínica Joslin de Boston, als Estats Units.

Tot i que abans de la dècada dels anys setanta alguns metges ja havien mostrat interès per l'educació dels pacients amb diabetis, no s'havien desenvolupat grans iniciatives, a diferència d'altres països en què la necessitat d'educar els pacients i formar els professionals d'infermeria es va generar inclús abans del descobriment de la insulina ${ }^{271,272,273}$. Als EUA, el Dr. Joslin ja defensava al 1914 la importància de formar infermeres per fer tasques d'educació i control de les persones amb diabetis ${ }^{182,274}$. Més tard, arran del descobriment de la insulina, la necessitat d'educar els pacients i formar els professionals es va fer encara més evident. Les infermeres itinerants en diabetis van tenir un paper molt important en l'atenció diabètica infantil ${ }^{182}$. A partir del descobriment dels hipoglucemiants orals, al 1950, van augmentar les expectatives de millorar el control metabòlic de les persones amb DM2 i d'especialitzar els professionals d'infermeria. De fet, l'educació diabètica va ser una de les primeres especialitats de la infermeria als EUA, Canadà i Austràlia ${ }^{183}$. Les infermeres especialistes es definien com a «algú capaç d'oferir una atenció d'alt nivell i de funcionar de manera autònoma» ${ }^{187}$.

L'inici de l'interès per l'educació del pacient amb diabetis a Catalunya va coincidir amb l'expansió de la importància de l'educació del pacient amb diabetis i del paper educador dels professionals d'infermeria en la majoria de països desenvolupats, a primers dels anys setanta del segle $x \mathbf{x}$, sobretot després dels estudis publicats per L. Miller et al. ${ }^{136}$ sobre els resultats d'un programa d'educació dirigit a 4000 pacients en el qual es va demostrar l'efectivitat en la reducció de complicacions agudes, ingressos hospitalaris i cost sanitari.

Per bé que no va ser un factor definitiu, el context sociopolític també va actuar com a facilitador. Entre mitjans i finals dels anys setanta, de mica en mica a Catalunya es va crear una consciència col-lectiva al voltant de la necessitat d'una salut pública en el sentit de promoció de la salut i la prevenció de la malaltia. Es parlava d'un canvi de paradigma en la medicina envers una manera més holística de tractar les malalties, especialment les cròniques, entre les quals la diabetis. Amb la restauració de la Generalitat, l'any 1977, la millora del sistema sanitari català va ser un dels primers objectius del Govern i el primer pas va ser l'elaboració, el 1979, del Mapa Sanitari de Catalunya ${ }^{275}$. 
La verdadera expansió de l'educació en diabetis a Catalunya es produeix en les dècades dels anys vuitanta i noranta del passat segle. El 1981 a l'Hospital de la Santa Creu i Sant Pau de Barcelona es va crear la primera Unitat d’Educació Diabetològica, formada per un equip interdisciplinari i amb infermeres amb dedicació exclusiva a l'educació de pacients i familiars i a altres professionals. A l'Hospital Clínic de Barcelona, el Dr. Figuerola estableix els primers criteris que han de regir l'educació de pacients, pels quals cal passar d'un model directiu i paternalista a un de participatiu i col·laboratiu, influenciat per les pràctiques de la Unitat de Diabetis de l'Hospital Cantonal de Ginebra, dirigit pel Dr. Assal. La majoria de professionals de la medicina van estar d'acord a potenciar l'educació de les persones amb diabetis i van acceptar el protagonisme que anaven adquirint els professionals de la infermeria, però d'altres s'hi van mostrar reticents, argumentant que assessorar o fer modificacions sobre les pautes de tractament i control podia suposar un cert grau d'intrusisme professional, i que proporcionar massa informació al pacient podria generar-li angoixa o complicar la relació metge-pacient ${ }^{248}$.

La creació del Consell Assessor sobre la Diabetis al 1983, presidit pel Dr. Gonçal Lloveras, va tenir un pes decisiu en la formació de professionals en diabetis i també va ser el suport polític més important que van tenir els professionals per a la implementació de l'educació diabetològica a Catalunya, la integració de professionals d'infermeria educadors en diabetis a totes les unitats especialitzades hospitalàries, la motivació dels professionals i els cursos de formació impartits per l'Institut d'Estudis de la Salut, amb la col-laboració de metges i infermeres. Es va aconseguir crear una xarxa de professionals formats i amb capacitat de formar-ne d'altres a totes les províncies de Catalunya. Sens dubte, el curs que més va influir va ser l'anomenat Curs de Formació de Professorat en Educació Diabetològica, coordinat pel metge Ignasi de Joan Creix i en el qual col-laborava el professorat del Centre Experimental d'Educació Sanitària de Perugia (Itàlia) i de la Unitat de Diabetis de l'Hospital Cantonal de Ginebra (Suïssa). Un fet diferencial d'aquesta formació en educació diabetològica respecte d'altres programes anteriors nacionals va ser el caràcter interdisciplinari i l'èmfasi a aprendre metodologia educativa centrada en els principis de la Universitat Experimental d'Educació Sanitària de Perugia i basada en aspectes antropològics que posaven el focus en la importància dels factors socioculturals, els significats que les persones donen a la malaltia i la participació de la comunitat, tant en la planificació d'intervencions educatives com en la de l'avaluació276,277, i destacà també la influència de la Unitat de Diabetis de l'Hospital Cantonal de Ginebra, que remarcava la necessitat d'implantar una metodologia didàctica, activa i participativa, tenint presents els factors que influeixen en el procés ensenyança-aprenentatge ${ }^{278}$. La importància que es donava al treball en equip i a la interdisciplinarietat es va reflectir en la creació de l'Associació Catalana d'Educadors en Diabetis. Els seus membres podien ser metges especialistes en endocrinologia, metges internistes o d'atenció primària, infermeres, dietistes, psicòlegs o qualsevol altre professional que acredités un interès per la diabetis i un treball relacionat amb l'educació de pacients o professionals. Aquesta perspectiva interdisciplinària va impulsar que la Societat Catalana de Diabetis, que integrava només el colllectiu mèdic, es fusionés amb l'Associació Catalana d'Educadors en Diabetis el 1992 per tal d'unificar en una sola societat tots els professionals que treballaven en el camp de la diabetis, cosa que va afavorir la interrelació entre els dos col-lectius. La fusió en una sola societat va ser un fet pioner en el nostre entorn i a la vegada modèlic, però els primers anys es respirava la sensació de pèrdua de rigor científic per 
part del col-lectiu mèdic i una pèrdua de lideratge o protagonisme per part dels professionals de la infermeria; en general, cap col-lectiu se sentia plenament integrat en l'altre. De fet, a algunes infermeres els va costar passar a formar part de la nova Associació Catalana de Diabetis, ja que la consideraven aliena als interessos de la infermeria. La normalització de noves funcions que contribueixen a la millora en la qualitat de l'atenció i al desenvolupament professional de la infermeria no sempre és acceptada pels diferents professionals o actors del sistema, atès que sovint els canvis són vistos com a amenaces. Aquests conflictes de competències són similars als que ha plantejat el recent decret de prescripció infermera. La resistència a regular de forma efectiva algunes competències dels professionals d'infermeria que ja estan establertes des de fa temps en altres països, aquí, tot i no haver problemes remarcables, genera en gran mesura desconfiança i malestar per part d'ambdós col·lectius ${ }^{279}$. La falta d'autonomia de la infermeria pot ser deguda, entre altres coses, a la condició majoritàriament femenina de la professió. Això no ha canviat, o ho fa lentament, ja que els patrons de comportament androcèntrics i corporativistes són difícils d'erradicar, principalment en el món de la medicina, tot i l'evident incorporació majoritària de les dones en els últims anys ${ }^{280}$.

Si en la dècada dels setanta la iniciativa i el protagonisme de l'educació la van tenir els metges, a partir de la dècada dels vuitanta van ser els professionals de la infermeria els que van assumir tant la responsabilitat de gestionar-la com la de formar altres professionals. Entre les primeres infermeres podem destacar Judit Rodegas, que va ser presidenta de l'Associació d'Educadors en Diabetis de Catalunya; Justa Úbeda, Pilar Villabona i Emilia Belda de la Unitat d'Educació en Diabetis del Hospital de Sant Pau, i Pilar Isla i Isabel Bailo, de l’Hospital Clínic de Barcelona. Pilar Isla va coordinar els tres cursos de Perfeccionament en Educació Sanitària Aplicada a la Diabetis que es van realitzar posteriorment al Curs de Formació de Professorat en Educació Diabetològic, a la meitat de la dècada dels anys noranta del segle xx va organitzar els primers cursos de postgrau en diabetis, i a partir del 2010 els de màster en diabetis de la Universitat de Barcelona. Aquesta expansió dels professionals d'infermeria com a educadors en diabetis en la dècada dels vuitanta coincideix amb el reconeixement en l'esfera mundial de la importància del paper de l'educador en diabetis, tot i que en altres països els cursos de formació reglats es van iniciar molt abans. Els primers programes per a educadors en diabetis es van introduir el 1970, i a partir del 1980 van passar a ser impartits a la Universitat ${ }^{183}$.

A escala mundial, a partir de la dècada dels vuitanta del passat segle, l'educació en diabetis es va començar a plantejar com una arma terapèutica de primera mà. Van sorgir grups d'estudi dedicats a l'educació de pacients amb diabetis, com el Diabetes Education Study Group (DESG) a Europa o l'Educational Council de l'American Diabetes Association (ADA) als EUA. A més, al 1990 es va produir la Declaració de Saint Vincent ${ }^{149}$, amb el patrocini de les Oficines Regionals per a Europa de l'OMS i de la IDF. Les seves conclusions van ser una sèrie de recomanacions dirigides als governs dels països membres per aplicar-les en les seves polítiques de salut, amb la intenció d'assolir uns objectius concrets i mesurables de millora de la situació global de l'atenció a la diabetis. La Declaració de Saint Vincent va subratllar la importància de l'educació tant per als pacients, les seves famílies o l'entorn com per a l'equip d'atenció sanitària. A Espanya, al 1997 es va crear el Grup d'Estudi d'Educació Terapèutica en Diabetis (GEETD) de la Societat 
Espanyola de Diabetis amb la finalitat de fomentar l'educació, la formació de professionals i la investigació en aquest àmbit. Actualment, totes les societats científiques relacionades amb la diabetis defensen la importància d'integrar programes educatius en el seu tractament. Els resultats del DCCT ${ }^{28}$ al 1993 i del UKPDS ${ }^{31}$ al 1998 van canviar l'enfocament de l'atenció a la diabetis, que va passar d'un control dels nivells de glucèmia i de la tensió arterial a la prevenció activa de complicacions i a la intensificació del tractament amb uns objectius metabòlics estrictes ${ }^{281}$. Això va tenir un efecte notable sobre el rol de l'educador en diabetis ${ }^{183}$, que ara precisa un alt grau d'especialització ${ }^{282}$. Es reconeix que la infermera especialista en diabetis integra coneixements, competències i capacitats per identificar les necessitats dels pacients i de les famílies i per interrelacionar-se amb ells ${ }^{232}$, ajuda a superar les diferents barreres socials i culturals ${ }^{283,284}$, constitueix un suport important per a l'autocura del pacient i de la família ${ }^{285}$ i proporciona una millor atenció 286,287 . Però en el nostre país no ha estat possible reconèixer l'especialitat de la infermera experta en diabetis, malgrat els esforços realitzats per aconseguir-ho, tant en l'àmbit nacional com autonòmic. A països com EUA, Canadà o Austràlia el desenvolupament d'estàndards per a l'educació diabètica i el procés d'homologació dels educadors ha suposat un creixent reconeixement dels valors dels educadors en diabetis. Les Seccions Consultives sobre Educació Diabètica i Diabetis en la Infància i Adolescència de la IDF es van crear al 1993 i han tingut un lideratge a escala mundial288. La promoció de la salut i la prevenció de la diabetis i les seves complicacions han aparegut com a funcions clau ${ }^{183}$.

Però, si bé s'encetaven els anys noranta amb una suposada consolidació de l'ET arreu de Catalunya, molta feina quedava per fer i molts van ser els canvis que es van produir cap a la segona dècada. Tot i que la reforma de l'Atenció Primària a Espanya es va produir al 1984 i l'aplicació de la Ley General de Sanidad al 1986, no va ser fins ben entrats els noranta que la figura de l'educador en diabetis als CAP va ser assumida per les infermeres generals, a les quals es delega la funció del control i el seguiment de les malalties cròniques, entre les quals la diabetis. Això suposa un pèrdua del suport i la potenciació de l'Educació Terapèutica en el nivell d'especialitat a canvi d'una aposta ferma per l'Assistència Primària, fet que genera que la figura de la infermera referent en diabetis que hi havia en la majoria de centres d'AP anés desapareixent. En el Decret 84/1985

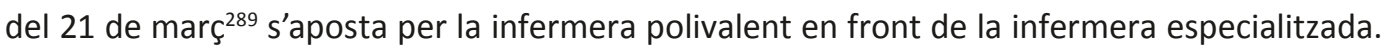
També en alguns hospitals es va qüestionar la continuïtat dels programes educatius a causa de la idea que l'AP era l'única responsable de l'educació dels pacients, tot i que en la majoria dels CAP es va aconseguir mantenir la figura de l'educador en diabetis.

El 1990 es va fer l'últim curs de perfeccionament en educació diabetològica i la formació en diabetis va deixar d'estar subvencionada, tutelada i consensuada, per adquirir un caràcter de voluntarietat. Ja no es basava en les necessitats detectades, sinó en les necessitats sentides individualment. Com que no existia cap tipus d'acreditació, algunes infermeres van haver de realitzar educació a les persones amb diabetis sense formació prèvia i d'elles mateixes depenia la responsabilitat de formar-se, de vegades de manera autodidacta o a través de l'oferta formativa de la indústria farmacèutica. Això ha provocat que existeixi una gran variabilitat no només entre nivells assistencials, sinó també en l'AE. Actualment, a Catalunya coexisteixen Unitats de Diabetis amb professionals molt experts que treballen amb programes educatius estructurats de diferents 
nivells, amb infermeres educadores a temps parcial que no disposen de programes estructurats ni de la infraestructura material i humana necessària per dur a terme una educació de qualitat. Cal destacar l'equip d'infermeres de l'Hospital Clínic de Barcelona com el de més impacte avui dia quant a projecció externa, tant en l'àmbit de Catalunya com en el d'Espanya i Europa.

D'ençà la dècada dels noranta alguns treballs realitzats mostren que l'educació terapèutica en diabetis a Catalunya no ha millorat substancialment. En un qüestionari que es va passar l'any 1992, es va posar de manifest que el 63,5 \% treballava amb programes d'educació terapèutica estructurat i que el 67 \% havia realitzat el curs bàsic de diabetis i el de perfeccionament en educació sanitària (annex 17). En un altre estudi no publicat fet el 2003 per l'ACD (annex 18), amb professionals de l'AP i l'AE, es va confirmar la pèrdua de la figura de l'educador en diabetis a l'AP, ja que només 5 centres d'un total de 130 van respondre que tenien aquesta figura, i també es va observar la poca implementació de l'educació grupal i de la disponibilitat de programes estructurats, especialment a l'AP. Un altre estudi realitzat al 2005 per Pilar Isla entre 213 professionals d'infermeria (el 58,7 \% d'hospital, el 40,8 \% d'AP i el 0,5\% de centres privats) en el qual es van excloure els professionals que treballaven en unitats de diabetis especialitzades hospitalàries, presentat en una taula rodona en el 8è Congrés de l'Associació Catalana de Diabetis, va mostrar que només el $25,4 \%$ dels professionals considerava que l'atenció que es proporcionava a les persones amb diabetis era bona, mentre que el $68,5 \%$ opinava que era regular i el 6,1 \% que era dolenta. Més del $80 \%$ va considerar que tant la seva formació com la de l'equip era regular, i el 97 \% creia que necessitava més formació en diabetis, nutrició i educació per a la salut. Després de gairebé 25 anys, s'observa en el present treball que el percentatge de professionals que diuen treballar amb programes estructurats a l'AE (el $81 \%$, amb una estimació ponderada del 75,4 \%) és lleugerament més elevat que en el que es va fer l'any 1992 o el 2003, però la formació en diabetis dels professionals es pot considerar igualment com a regular.

Actualment, I'Institut Català de la Salut (ICS) s'ha acollit a una nova estratègia anomenada programa «Pacient Expert Catalunya», com ja ho va reflectir el Pla de Salut 2011-2015. Aquesta estratègia no té en compte la formació generalitzada dels professionals que tracten la diabetis, que a causa de l'elevada prevalença d'aquesta malaltia, són tots, sinó que promou una formació dirigida només a aquells professionals que es faran càrrec d'aquests programes a cada centre i als pacients escollits per representar el «pacient expert».

També ha existit una falta de lideratge i d'iniciativa per part dels referents inicials. La falta de suport institucional i de recursos va ocasionar que al cap d'uns anys alguns professionals referents desertessin i anessin a la medicina privada o a un altre tipus de feina dins de la professió. La falta d'investigació i de publicació de resultats va dificultar una argumentació sòlida per defensar la figura de la infermera educadora en diabetis. Això es deu a la falta de formació en investigació de la majoria de professionals de la infermeria, fins que no es va aconseguir l'accés a estudis de màster i doctorat, juntament amb la pròpia dificultat d'avaluar els programes educatius. La majoria d'intervencions que milloren el control metabòlic depenen dels pacients; per tant, si els professionals tenen en compte els objectius del pacient i els proporcionen el suport per assolir-los, les intervencions clíniques tenen més possibilitats d'èxit ${ }^{183,286,290}$. L'evidència científica 
s'obté a partir de l'avaluació sistemàtica dels resultats d'investigacions i estudis controlats, i això permet prendre les millors decisions per al pacient. El problema amb l'ETD és que existeixen molts obstacles per plantejar estudis prospectius aleatoris a llarg termini, atès que el procés educatiu és molt complex. Hi ha multitud de variables de tipus psicològic i sociocultural que són molt difícils de quantificar. En la relació professional-pacient, i especialment en la relació educativa, existeix una part important de subjectivitat que possibilita acostar-se l'un a l'altre i, en les guies clíniques, aquest aspecte només es preveu de manera teòrica. Per tot això, la medicina o la infermeria basada en l'evidència, com a metodologia per millorar la pràctica professional i educativa, hauria de complementar-se i enriquir-se amb les aportacions de la investigació qualitativa, però la investigació qualitativa en salut a Espanya va ser molt escassa fins a finals del segle passat ${ }^{281}$.

El 2014 es va publicar a la revista Avances en diabetología de la SED el posicionament d'aquesta societat sobre el perfil curricular i professional dels professionals d'infermeria experts en l'atenció a les persones amb diabetis, els seus familiars i cuidadors ${ }^{181}$. En aquest article es fa constar el suport que dona la SED al perfil acadèmic del professional d'infermeria expert/especialista en diabetis per la via del màster o postgrau universitari, així com la necessitat d'una formació continuada. El perfil de competències esta basat en 5 dominis: I. Fisiopatologia, Epidemiologia i Guies Clíniques de Diabetis; II. Cures culturalment competents durant tota la vida de la persona amb DM; III. Habilitats d'ensenyança-aprenentatge; IV. Educació per a l'autogestió del tractament, i v. Planificació, gestió i investigació per a una educació terapèutica eficient. Al 2015, la Universitat de Barcelona ha endegat el Máster para la Atención y Educación de las Personas con Diabetes ${ }^{291}$, de 60 ECTS. El programa s'ha basat en les recomanacions formatives del DESG i en el currículum internacional per a professionals de l'educació en diabetis que publiquen la IDF ${ }^{292}$ i l'American Association of Diabetes Educators (AADE) ${ }^{293}$. Aquesta formació obre la possibilitat perquè professionals dels diferents àmbits d'atenció tinguin accés a aquests estudis reglats i acreditats.

El paper dels professionals d'infermeria en l'educació dels pacients amb diabetis ha anat progressant en les últimes dècades, arran de l'aparició de noves i sofisticades teràpies que han incrementat la necessitat d'equips especialitzats amb professionals d'infermeria cada vegada més formats, per donar resposta a les noves necessitats i expectatives de les persones amb diabetis, independentment de l'àmbit d'atenció. En aquest estudi s'ha observat que la formació en diabetis dels professionals d'infermeria es heterogènia, però que el nivell més alt de formació es troba en el collectiu de professionals que treballen a l'AE, probablement perquè molts d'ells són professionals que es van introduir en l'educació als anys vuitanta, en plena època d'expansió de l'ET a Catalunya, i el mateix àmbit de treball ha motivat la necessitat de formació contínua per tal d'adequar-se a les necessitats dels pacients. Aquest aspecte és especialment rellevant quan diversos estudis han demostrat que la formació dels professionals, reglada i acreditada, s'associa a una major probabilitat de gestionar i educar en aspectes més complexos del tractament ${ }^{294} \mathrm{i}$ a una millora del control de la diabetis dels pacients als quals atenen295. D'altra banda, s'observa que l'edat mitjana del col-lectiu educador de l'assistència especialitzada es troba en edats properes a la jubilació ( 51,3 anys), i això pot donar lloc a un problema relacionat amb el recanvi professional. Aquesta dada es corrobora en altres estudis a 
Europa com, per exemple, a Suècia, on l'edat mitjana de les infermeres especialistes en diabetis és de 53,3 anys ${ }^{296}$, i al Regne Unit, on el 2011, tot i disposar de cursos acreditats d'educadors en diabetis, especulaven que el $44 \%$ es retiraria en un termini de 10 anys, amb poques expectatives de professionals capacitats per poder ocupar els seus llocs de treball ${ }^{297}$. En aquest sentit, a Catalunya, el Máster para la Atención y Educación de las Personas con Diabetes pot ser una oportunitat per cobrir aquests llocs de treball en un termini curt de temps.

En ambdós àmbits, però principalment en l'AP, hi ha un espai de millora en la implementació de programes estructurats per a l'educació de les persones amb diabetis. Això sembla que no és exclusiu del nostre context, perquè aquests resultats coincideixen amb altres estudis on, a més, s'observa que existeix una confusió entre el contingut d'una educació estructurada i les activitats d'informació 298 , S'observa que l'atenció al peu diabètic està més centrada en l'exploració, especialment a l'AP. Els resultats sobre la baixa aplicació de programes estructurats per a l'educació i l'atenció al peu diabètic també estan en concordança amb els resultats d'una tesi doctoral ${ }^{299}$ sobre el paper d'infermeria en l'atenció del peu diabètic a Catalunya l'any 2009, en què es demostra que la manca de material específic per a l'exploració, la falta de formació dels professionals i la necessitat d'organitzar i coordinar l'atenció al peu diabètic a l'AP són les principals barreres per aplicar aquests programes. Altres estudis a escala internacional demostren que l'atenció o la prevenció del peu diabètic encara són un repte per a molts professionals, ja que un estudi publicat el 2010 on l'objectiu era avaluar les estratègies de prevenció de peu diabètic en 300 pacients d'alt risc (150 pacient amb úlcera i 150 pacients amb diàlisi), es va observar que cap pacient ( $0 \%$ ) del grup amb úlceres, i només un 1,3\% del grup amb diàlisi, havien rebut prèviament educació per a la prevenció del peu diabètic ${ }^{300}$. A Espanya, un estudi publicat el $2014^{301}$ pel Grup Espanyol de Peu Diabètic de la SED amb l'objectiu de determinar el nombre d'Unitats de Peu Diabètic existents a Espanya, els professionals que hi treballen i la població que cobreixen, va obtenir un percentatge de resposta de només el $13 \%$. Els responsables de l'estudi valoren la baixa participació com un reflex de la poca atenció que normalment també posen els endocrinòlegs espanyol (a la majoria dels quals anava dirigit el qüestionari) al peu diabètic. El professional de la podologia especialitzat en peu diabètic, tot i no estar inclòs en el sistema nacional de salut, és una peça clau en el maneig d'aquesta patologia. El problema és la falta de competències professionals, juntament amb la dificultat de rebre formació específica a causa de la inexistència d'estudis reglats que el capacitin en un camp tan important i a la vegada tan oblidat com el de l'atenció al peu diabètic ${ }^{302}$. La creació de més Unitats Multidisciplinàries de Peu Diabètic, estretament coordinades amb els centres de referència i amb la participació de professionals d'infermeria, podria facilitar l'aplicació d’aquests programes específics.

Hi ha discrepància respecte a la participació de la família en l'educació dels pacients entre els resultats d'aquests estudi i els resultats de l'estudi DAWN2 a Espanya303. En aquest estudi la participació de la família era del 32,5\% a l'AP i del $65 \%$ a l'AE, mentre que a l'estudi DAWN2 només el $21 \%$ manifestava haver participat en les activitats educatives dels seus familiars. Independentment d'aquesta discrepància de resultats, els professionals d'infermeria s'han de plantejar l'educació dins d'un programa estructurat en què es prevegi la participació de la família com a condició indispensable. 
En els canvis que recentment s'estan produint en l'enfocament de l'atenció a les malalties cròniques, la telemedicina hi pot tenir un paper decisiu. Tot i que la utilització de mitjans telemàtics per part d'infermeria a l'AP ha demostrat una millora de resultats clínics i d'autoeficàcia en pacients amb $\mathrm{DM} 2^{304}$, aquest estudi fa palesa la baixa implementació de programes i plataformes de descàrregues de dispositius que permetin l'ús de la telemedicina, específicament a I'AP. Sovint es tendeix a infravalorar les capacitats de les persones d'edat més avançada a I'hora de fer servir aquests mitjans, però el cas és que també les motivacions o l'interés dels professionals i les diferències organitzatives dels centres poden influir en la seva utilització ${ }^{305}$. La formació dels joves professionals ha estat molt més lligada a les noves tecnologies que la d'aquells professionals de més edat, i això pot haver contribuït que en l'àmbit de l'AE, on l'ús de la tecnologia per al tractament de la diabetis es més comú, els professionals més joves i amb més formació acadèmica usin de manera més significativa la via telemàtica per atendre els pacients.

S'observa que l'educació grupal, malgrat que ha donat bons resultats tant per a la prevenció de la malaltia ${ }^{14,168,169} \mathrm{com}$ per millorar resultats clínics i d'adherència al tractament, està poc implementada a l'AP. En un estudi realitzat a Espanya ${ }^{306}$ amb 517 pacients amb DM2 controlats a l'AP, només I'1,7 \% havien estat inclosos en grups d'educació, i els principals motius, segons subratllaven els autors, eren el volum de pacients assignats a cada centre i les competències dels professionals en el maneig de grups de pacients. En el present estudi, l'espai adient per fer educació, els anys d'experiència en diabetis i la formació dels professionals han demostrat ser també aspectes que afavoreixen l'aplicació de programes amb intervencions d'educació grupal independentment de l'àmbit d'atenció.

Els professionals d'infermeria que lideren el procés educatiu i acompanyen els pacients en el procés de la malaltia han de donar el suport necessari per ajudar els pacients a gestionar el seu tractament. Els factors psicosocials juguen un paper important en el control de la diabetis, el qual pot afectar considerablement l'adherència terapèutica ${ }^{63}$, i d'aquí la necessitat de detectar-los per donar-hi el suport necessari, ajudar a gestionar-los o derivar el pacient a equips especialitzats. En aquest estudi, a diferència del que va mostrar el DAWN2 ${ }^{307}$, els professionals d'infermeria se senten capaços d'avaluar els problemes psicosocials que comporta la malaltia, però, en canvi, no se senten tan capacitats per donar-los el suport necessari i menys encara per ajudar els pacients a gestionar-los. Aquests problemes són molt comuns i alguns d’ells costen d'abordar si no hi ha una bona col·laboració amb equips experts de psicòlegs.

Es disposa de poc estudis que comparin les competències de les infermeres en diabetis entre els diferents àmbits d'atenció, l'AP i l'AE ${ }^{240,308}$. Alguns països com Suècia, Anglaterra o els EUA tenen reconeguda la titulació d'infermera especialista en diabetis, i aquesta tant pot exercir a I'AP com a l'AE ${ }^{296,309}$. Un dels principals problemes rau en el fet que no existeix un acord sobre quines són les competències que ha desenvolupar la infermera especialista en diabetis i en què es diferència exactament de la infermera generalista. Els estudis que han intentat avaluar la diferència de competències entre aquests dos perfils professionals ${ }^{240,308}$ posen de manifest que les infermeres de l'AE realitzen tasques corresponents a una pràctica més avançada de la infermeria, com pot ser el maneig de tractaments més complexos i basats en les noves tecno- 
logies, així com el lideratge tant per al desenvolupament de programes educatius com per a la coordinació de l'atenció multidisciplinària dels pacients amb diabetis o de les seves famílies.

El fet que no es trobin diferències en les prestacions que es proporcionen als pacients, especialment aquelles relacionades amb diferents aspectes del tractament, com ara l'alimentació i l'exercici, probablement es pot explicar perquè el tipus de qüestionari no expressava en profunditat com es duien a terme aquestes prestacions; per exemple, l'educació per a l'exercici es pot entendre com el fet de recomanar caminar cada dia a una persona amb DM2 o bé com a educar en relació amb l'ajustament del tractament a una persona amb DM1 que fa esport de competició. També es podria explicar atenent a l'existència d'ambigüitat en els rols dels professionals de cada àmbit, atès que no existeix cap definició ni límit de competències. D'igual manera, es pot argumentar la poca diferència que hi ha entre l'avaluació de resultats d'aprenentatge i la dels resultats clínics entre ambdós nivells d'atenció.

Malgrat que el rol de pràctica clínica pot estar ben definit gràcies als protocols d'assistència $^{225}$, quan s'analitzen detalladament algunes de les prestacions de pràctica avançada que corresponen a aquest rol s'observa que en alguns països, com els EUA, una de les prestacions que més destaca en la infermeria especialitzada és el gran nivell d'implicació que es produeix en la prescripció de medicaments ${ }^{308}$. En el nostre àmbit ha quedat invalidada la prescripció infermera arran del Decret 954/2015 310 , que regula la indicació de l'ús i l'autorització de dispensació de medicaments i productes sanitàries d'ús humà per part dels infermers. Aquest decret també afecta el maneig de la medicació; en tot cas, els resultats d'aquest estudi, d'una banda, no mostren cap diferència en aquesta competència per àmbit d'atenció, però de l'altra sí que és un aspecte que s'avalua en els programes d'educació, ja que cal ensenyar al pacient com fer les modificacions oportunes per tal d'ajustar el tractament en les situacions canviants de la vida diària. Cal destacar que les respostes dels professionals es van obtenir abans de la signatura de l'esmentat decret. En canvi, els resultats posen de manifest que les infermeres de l'AE assumeixen més competències relacionades amb el maneig de teràpies noves i sofisticades, d'acord amb les recomanacions de les guies clíniques i els documents de consens en què s'aconsella que siguin els professionals d'infermeria amb habilitats especifiques i d'expertesa qui atenguin les necessitats educatives dels pacients que utilitzen aquestes teràpies.

La presència més destacada del rol educador tant per a altres professionals com per als pacients, i els rols d'assessor o consultor i de col-laborador o enllaç tant per als pacients com per a la mateixa organització en l'AE, pot justificar un reconeixement del lideratge dels professionals que treballen en aquest àmbit, tal com es reconeix en la literatura ${ }^{311}$. La bona puntuació obtinguda en l'AE del rol assessor o consultor pot sustentar la capacitat d'introduir canvis i millorar la pràctica dins d'un marc interdisciplinari, ja que més enllà de respondre a les necessitats dels pacients o de les famílies, aquest rol pot promocionar l'apoderament tant de la infermeria clínica com dels altres professionals de l'equip d'atenció, ja que recentment ha estat descrit com un pont entre el coneixement científic i la pràctica clínica ${ }^{312}$. El rol d'enllaç en aquest estudi queda ben definit a favor de l'AP, però en alguns estudis es produeix ambigüitat, atès que és un rol que 
es pot compartir amb altres professionals, com poden ser els metges, els quals també tenen la competència de derivar els pacients a altres professionals ${ }^{225}$.

En general, la producció científica infermera a Espanya s'ha incrementat des de la seva incorporació a la universitat, tal com s'ha comentat anteriorment, i, de fet, un estudi del $2013^{313}$ mostra que la província de Barcelona és la que més producció científica genera, i que aquesta prové majoritàriament dels hospitals. Moltes investigacions d'infermeria es donen a conèixer principalment a congressos o esdeveniments científics o acadèmics, però perquè realment aquests resultats siguin coneguts per una majoria de professionals cal fer una sèrie de passos que no sempre la infermeria pot o està disposada a fer, com és l'elaboració d'un article científic $^{314}$. En aquest estudi, tot i que el rol d'investigador està més present a l'AE, s'observa una baixa puntuació en totes les seves competències, i hi destaca la limitació dels professionals a I'hora d'identificar problemes i de fer-se preguntes per a la investigació, primer pas per iniciar un treball d'investigació. Probablement, aquest fet es deu a la falta de formació científica dels professionals en la carrera d'infermeria, però en altres països, com el Regne Unit, es troben en la mateixa situació degut a la falta de desenvolupament professional de les infermeres especialistes en diabetis en els darrers deu anys ${ }^{315}$. En aquest sentit, cal confiar en les noves generacions infermeres, amb estudis de grau, màster i doctorat i dotades d'una millor formació en l'àmbit de la investigació. Millorar la capacitat investigadora de la infermeria contribuiria a cobrir el buit que existeix entre la investigació i la pràctica clínica ${ }^{311}$.

En les estratègies i documents de polítiques sanitàries ${ }^{196,316}$ s'expressa la importància de coordinar els diferents nivells assistencials, per bé que la realitat que es manifesta per part dels professionals que han participat en aquest estudi palesa un dèficit en la coordinació i la interrelació entre els diferents nivells assistencials. I s'ha vist que és un problema no resolt, que està generalitzat en la majoria dels països ${ }^{317}$ i que, a més, pot ser motiu d'un baix grau de satisfacció laboral dels professionals implicats, tal com va demostrar un estudi fet a Espanya el $2001^{318}$. Diversos estudis han avaluat el grau de satisfacció laboral dels professionals d'infermeria en diverses àrees de la professió, ja que també s'ha observat que una major satisfacció laboral està lligada a una major qualitat en l'atenció dels professionals d'infermeria i, en conseqüència, a una major satisfacció del pacient ${ }^{319}$. En el present estudi també s'ha avaluat el grau de satisfacció dels professionals, però es fa difícil fer comparacions amb altres d'estudis, perquè s'han utilitzat instruments de mesures diferents. Tanmateix, en un estudi realitzat el $2012 \mathrm{amb}$ professionals d'infermeria d'AP i $A E$ en l'àrea de salut de Toledo ${ }^{320}$, s'hi va observar que no hi havia diferències significatives quant a la satisfacció global entre els professionals d'ambdós àmbits i que la dimensió pitjor puntuada era la relació amb els companys, a diferència d'altres estudis ${ }^{318,321,322}$ on aquesta dimensió era de les millors puntuades, com passa en aquest estudi. Diversos estudis coincideixen que un dels factors que ocasionen una baixa satisfacció laboral és el salari ${ }^{318,321}$. Els estudis que han comparat la satisfacció de professionals d'ambdós àmbits mostren que és a l'AE on es manifesta més insatisfacció amb el salari, cosa que pot interferir en el desenvolupament professional ${ }^{318}$ i que també pot explicar que siguin els professionals amb més formació universitària els qui tinguin un pitjor grau de satisfacció en relació amb la pròpia formació, amb el temps de dedicació als pacients, amb l'organització de la feina i amb el temps que poden dedicar a l'oci o la família, tal 
com revelen els resultats d'aquest estudi. No incentivar econòmicament la formació universitària pot minimitzar el desenvolupament de competències relacionades amb una pràctica assistencial de qualitat o de lideratge d'aquells professionals més preparats. En canvi, tenir més hores de formació acreditada (on s'han inclòs els professionals que tenen cursos de formació continuada acreditats) incrementa el nivell de satisfacció pel que fa al salari i l'organització sanitària, la relació amb els companys i els pacients i el temps per a l'oci o per dedicar a la família. Això es podria explicar pensant en la diferència que suposa en temps i esforç personal fer estudis universitaris o fer cursos de formació continuada; aquests últims se solen acreditar d'acord amb l'assistència, i no amb les competències adquirides.

La infermeria de l'AE, de cara a una formació més específica i profunda en una determinada patologia, hauria de gaudir d’un paper més destacat en la participació en òrgans de direcció. En general, existeix un distanciament dels professionals envers les direccions dels centres, fet que pot crear un cert grau d'insatisfacció deguda a la manca de reconeixement d'expertesa ${ }^{318}$. En aquest estudi el rol de director és el que ha obtingut una pitjor puntuació, i això pot indicar que la infermeria en cap dels àmbits d'atenció no se sent reconeguda per participar en aspectes de política sanitària relacionada amb la diabetis, la qual cosa pot estar lligada també a la baixa puntuació obtinguda amb relació al grau de satisfacció envers l'organització sanitària. Hi ha estudis ${ }^{323}$ que han demostrat que els entorns de treball en què membres dels òrgans de direcció, com ara els supervisors, involucren els professionals en la presa de decisions i en la definició de tasques, estan positivament relacionats amb la satisfacció laboral. Alguns autors ${ }^{324}$ proposen augmentar el nivell de satisfacció dels professionals implicant-los en la presa de decisions de l'equip assistencial, a més potenciar-ne la participació en la gestió, l'elaboració d’objectius i de guies clíniques i, fins i tot, en la contractació.

La influència que genera l'edat sobre el nivell de satisfacció és molt dispar, de manera que hi ha resultats contraposats segons els estudis: d'una banda, hi ha qui ha observat que la satisfacció laboral augmenta en paral·lel amb l'edat ${ }^{325,326,327,328}$; altres revelen que l'edat no hi té cap relació329,330, i uns altres assenyalen que com més alta és l'edat, menor és el grau de satisfacció laboral ${ }^{331}$ En aquest estudi s'ha observat que l'edat influeix de forma diferent depenent de l'àmbit de treball ( $A P \circ A E)$, els recursos per realitzar una educació de qualitat, com es disposar d'espai adient, o el salari. Un altre aspecte que s'ha relacionat amb un alt grau de satisfacció en les diferents dimensions avaluades ha estat el fet de disposar d'espai adient per fer educació (una aula), el qual representa un recurs pràcticament indispensable a l'hora de proporcionar una educació terapèutica de qualitat que permeti l'aplicació de tècniques i estratègies pedagògiques, com és, entre d'altres, l'educació grupal. No s'han trobat estudis que valorin especialment aquesta característica, però sí que s'ha descrit que l'estructura física on es desenvolupa la feina repercuteix en el grau de satisfacción ${ }^{322,332}$.

En general, la implementació de la infermera clínica especialista proporciona una oportunitat de millora en l'administració de les cures d'infermeria. Per tant, seria desitjable integrar aquest nou perfil en el Sistema Nacional de Salut, per bé que requereix el compromís de les universitats, dels hospitals i de l'administració pública ${ }^{333}$. 


)

) 


\section{CONCLUSIONS}

\section{Primera fase de l'estudi}

L'educació terapèutica en diabetis a Catalunya es va començar a desenvolupar a principis dels anys vuitanta del passat segle. Els hospitals pioners a crear unitats d'educació terapèutica amb programes impartits per equips multidisciplinaris van ser l'Hospital de Sant Pau i l'Hospital Clínic de Barcelona.

Tot i que la iniciativa va partir dels metges endocrinòlegs, aviat van ser les infermeres les qui van assumir i liderar el desenvolupament i l’aplicació de programes d'educació terapèutica.

Les principals motivacions d'aquests i d'altres professionals que es van adherir al canvi de paradigma van ser, inicialment, els resultats científics que s'havien publicat a finals dels anys setanta al voltant de l'eficàcia de programes d'educació estructurats, tant als EUA com a Europa, els avenços en el tractament de la diabetis, com ara l'aparició de les tècniques d'autocontrol, i la necessitat de superar el model biomèdic per endinsar-se en un altre de més holístic, com és el biopsicosocial.

Els pobres resultats d'una educació terapèutica impartida mitjançant mètodes unidireccionals per part de professionals amb molt bona voluntat però mancats de formació en didàctica o pedagogia va motivar la necessitat d'iniciar un procés de formació dels professionals en el camp de l'educació terapéutica.

L'Institut d'Estudis de la Salut i el Consell Assessor sobre la Diabetis a Catalunya van ser de gran rellevància en la formació de professionals, especialment durant la dècada dels vuitanta. El curs Formació de Professorat en Educació Diabetològica, impartit amb la col·laboració del Centre Experimental d'Educació Sanitària de Perugia i la Unitat de Diabetis de I'Hospital Cantonal de Ginebra, dirigida per l'equip del Dr. Assal, va ser el curs de formació de professionals més important, ja que va permetre l'adquisició de competències pedagògiques, de comunicació, de planificació i avaluació de programes educatius, així com també crear una xarxa d'equips multidisciplinaris amb professionals d'infermeria dedicats a l'educació terapéutica dels pacients amb diabetis a les quatre províncies catalanes.

Els cursos de formació en diabetis i educació terapèutica, juntament amb el suport polític, van permetre la creació d'una xarxa de professionals, majoritàriament professionals d'infermeria, amb formació específica en diabetis i educació terapèutica què podien assumir el càrrec d'educador en diabetis dins de les unitats de diabetis dels hospitals, a l'assistència primària no reformada i als CAP II (centres d'atenció especialitzada). 
L'associació de professionals ha estat un model de treball en equip i ha contribuït al llarg dels anys a la formació i el desenvolupament científic de la malaltia. També les associacions de pacients han tingut un paper molt destacat en el desenvolupament de l'educació terapèutica, ja que han assumint tasques de divulgació científica, d'informació als pacients i de millora per a la integració social de la malaltia.

Un cop acabada la reforma de l'AP, als anys noranta del segle XX, es va potenciar l'AP davant de l'AE, i la figura de l'educador en diabetis va quedar relegada als hospitals i a alguns CAP II. L'estructura de professionals formats en educació terapèutica s'ha mantingut bàsicament als hospitals.

\section{Segona fase de l'estudi}

Els resultats d'aquest estudi confirmen la hipòtesi plantejada segons la qual la implantació de l'educació terapèutica a Catalunya és una realitat, per bé que hi ha una desigualtat pel que fa a la formació dels professionals, a la disponibilitat de recursos tant materials com humans i a la planificació i avaluació de programes educatius

L'edat influeix en el grau de satisfacció de manera diferent en funció de si l'àmbit de treball és $A P$ o $A E$, dels recursos per dur a terme una educació de qualitat, la qual cosa inclou disposar d'un espai adient a tal fi, i del salari.

Actualment, els professionals d'infermeria de l'assistència especialitzada:

- Tenen més formació universitària en diabetis (màster o postgrau) i més formació continuada en diabetis i educació terapèutica. El desenvolupament dels seus rols correspon al d'una infermera clínica especialista.

- Tenen més programes d'educació estructurada per a l'educació dels pacients amb diabetis, utilitzen més la via telemàtica per al control i el seguiment dels pacients i avaluen més resultats d'aprenentatge, com ara habilitats tècniques, resolució de problemes i actituds.

- Apliquen més programes que combinen les estratègies d'educació individual i grupal.

- Tenen més capacitat per realitzar recerca i per publicar-ne els resultats.

Els professionals d'infermeria de l'assistència primària:

- Tenen un baix nivell de formació específica en diabetis i educació terapèutica.

- Les prestacions que ofereixen estan més centrades en els canvis de l'estil de vida (alimentació, exercici, deshabituació del tabac, control de la dislipèmia, etc.) i en el calendari vacunal.

- Tenen més disponibilitat d'espai per realitzar educació grupal, però només la meitat utilitzen aquesta metodologia. Els cal formació i experiència. 
En ambdós àmbits d'assistència:

- Existeix un espai de millora tant en la formació en diabetis dels professionals com en el desenvolupament i l'aplicació de programes estructurats.

- Destaca l'escassa coordinació entre els diferents nivells d'atenció.

\section{Què aporta aquest estudi}

Aquest estudi dona a conèixer quina ha estat l'evolució de l'educació terapèutica en diabetis a Catalunya des dels anys setanta fins a l'actualitat, alhora que aporta informació rellevant respecte de l'organització de l'atenció a la diabetis per part del col-lectiu d'infermeria, diferenciat per àmbits d'atenció (primària i especialitzada). Analitzar històricament l'evolució de l'Educació Terapèutica a Catalunya pot servir per adoptar mesures que afavoreixin el desenvolupament professional de la infermeria experta en educació terapèutica i diabetis.

Com a aspecte destacable es constata la falta de coordinació entre ambdós nivells assistencials, així com la necessitat de millorar l'educació terapèutica dels pacients impartida mitjançant programes estructurats als diferents àmbits d'atenció i la formació dels professionals implicats.

\section{Punts forts}

No hi ha actualment a Espanya ni a Catalunya cap estudi similar que s'hagi plantejat un recorregut històric en un àmbit del tractament de la diabetis com el de l'educació terapèutica i tampoc cap que avaluï en profunditat la formació, les competències i el desenvolupament professional de la infermeria que atén persones amb diabetis.

\section{Punt febles}

Una de les principals limitacions d'aquest estudi és la manca d'un cens de professionals que treballen en els diferents nivells d'atenció. Aquest fet ha dificultat el càlcul de la mostra.

Una altra limitació és el mateix disseny de l'estudi. Com que es tracta un estudi descriptiu, no permet establir el factor causal dels resultats obtinguts, fet que dificulta la recerca de solucions.

\section{Implicacions pràctiques}

Aquest estudi pot representar el primer pas per desenvolupar altres investigacions del marc competencial de la infermeria en l'educació terapèutica en diabetis en totes les seves àrees. 
214

$$
0
$$




\section{BIBLIOGRAFIA}

1 American Diabetes Association. Diagnosis and Classification of Diabetes Mellitus. Diabetes Care. 2013; 36(Suppl. 1): S67-S74.

2 American Diabetes Association. Standards of Medical Care in Diabetis 2014. Diabetes Care. 2014;37(Suppl. 1):S14-S80.

3 Report of the Expert Committee on the Diagnosis and Classification of Diabetes Mellitus. Diabetes Care. 1997; 20(7):1183-97.

$4 \quad$ Alberti KM, Zimmet PZ. Definition, diagnosis and classification of diabetes mellitus and its complications. Part 1: Diagnosis and classification of diabetes mellitus. Provisional report of a WHO consultation. Diabet Med. 1998; 15(7): 539-53.

5 European Diabetes Policy Group 1999. A desktop guide for the management of type 2 diabetes mellitus. Diabet Med. 1999; 16(9): 716-30.

6 International Diabetes Federation, 2012. Clinical Guidelines Task Force Global Guideline for Type 2 Diabetes. Disponible a: http://www.idf.org/sites/default/files/IDF-Guideline-for-Type-2-Diabetes.pdf [Consulta 30-04-2015]

7 The International Expert Committee. International Expert Committee Report on the Role of the A1C Assay in the Diagnosis of Diabetes. Diabetes Care. 2009; 32(7):1327-34.

8 American Diabetes Association. Diagnosis and classification of diabetes mellitus. Diabetes Care. 2010; 33 (Suppl. 1):S62-S69.

9 Bloomgarden ZT. A1C: recommendations, debates, and questions. Diabetes Care. 2009;32(12):141-47.

10 Práctica clínica en la DM2. Análisis crítico de las evidencias por la red GDPS. Disponible a: http://www.redgdps.org/gestor/upload/file/guias/guia_gedaps_practica-cinica-2010. pdf [Consulta 30-04-2015]

11 Expert Committee on the Diagnosis and Classification of Diabetes Mellitus. Report of the Expert Committee on the Diagnosis and Classification of Diabetes Mellitus. Diabetes Care. 2003; 26(Suppl. 1):S5-S20.

12 Genuth S, Alberti KG, Bennett P, Buse J, Defronzo, Khan R, et al.; Expert Committee on the Diagnosis and Classification of Diabetes Mellitus. Follow-up report on the diagnosis of diabetes mellitus. Diabetes Care. 2003;26(11):3160-67. 
13 The Diabetes Prevention Program Research Group: Reduction in the incidence of type 2 diabetes with lifestyle intervention or metformin. N Engl J Med. 2002; 346(6):393-403.

14 Costa B, Barrio F, Cabré JJ, Piñol JL, Cos X, Solé C, et al. DE-PLAN-CAT Research Group. Delaying progression to type 2 diabetes among high risk spanish individuals is feasible in real life in primary health care settings using intensive lifestyle intervention. Diabetologia. 2012; 55 (5):1319-28.

15 Guariguata L, Whitingb DR, Hambletonc I, Beagley J, Linnenkampa U, ShawJE. Global estimates of diabetes prevalence for 2013 and projections for 2035. Diab Res Clin Pract. 2014; 103(2): 137-49.

16 International Diabetes Federation. The IDF Diabetes Atlas. $6^{\text {th }}$ Ed. Brussels Belgium. IDF 26/11/2011.Disponible a: http://www.idf.org/diabetesatlas. [Consulta: 27-05-2014]

17 Soriguer F, Goday A, Boch-Comas A, Bordiú E, Calle-Pascual A, Carmena E, et al. Prevalence of diabetes mellitus and impaired glucose regulation in Spain: the Di@bet.es Study. Diabetologia. 2012; 55(1):88-93.

18 Goday A. Epidemiologia de la diabetes y sus complicaciones no coronarias. Rev Esp Cardiol. 2002;55(6):657-70.

19 Corcoy R, Lumbreras B, Bartha JL, Ricart W. Grupo Español de Diabetes y Embarazo. Nuevos criterios diagnósticos de diabetes mellitus gestacional a partir del estudio HAPO. ¿Son válidos en nuestro medio?. Av Diabetol. 2010;26(3):139-42.

20 Yau JW. Rogers SL, Kawasaki R, Lamoureux EL, Kowalski JW, Bek T, et al. Global prevalence and major risk factors of diabetic retinopathy. Diabetes Care. 2012; 35(3) 556-64.

21 Vila L, Viguera J, Alemán R. Retinopatía diabética y ceguera en España. Epidemiología y prevención. Endocrinol Nutr. 2008;55(10):459-75.

22 Cerdà M, Fernández M, Goday $\mathrm{A}$, Cano JF. Revisión de las complicaciones crónicas de la diabetes mellitus en España. JANO. 2007; 1644: 27-30. Disponible a: http://www.jano.es/ ficheros/sumarios/1/0/1644/27/1v0n1644a13100963pdf001.pdf [Consulta 27-05-2014].

23 Rodriguez-Poncelas A, Miravet-Jiménez S, Casellas A, Barrot-De La Puente JF, Franch-Nadal J, López-Simarro F, et al.Prevalence of diabetic retinopathy in individuals with type 2 diabetes who had recorded diabetic retinopathy from retinal photographs in Catalonia (Spain).Br J Ophthalmol. 2015; 99(12):1628-33. Disponible a: https://www.ncbi.nlm.nih. gov/pmc/articles/PMC4680151/ [Consulta 27-05-2014] 
24 Gross JL, Azevedo MJ, Silveiro SP, Canani LH, Caramori ML, Zelmanovitz T. Diabetic nephropathy: diagnosis, prevention, and treatment. Diabetes Care. 2005;28(1):164-76.

25 Tesfaye S, Selvarajah D. Advances in the epidemiology, pathogenesis and management of diabetic peripheral neuropathy. Diabetes Metab Res Rev. 2012; 28(Suppl. 1): 8-14.

26 American Diabetes Association. Economic Costs of Diabetes in the U.S. in 2012. Diabetes Care. 2013; 36(4):1033-46.

27 Crespo C, Brosa M, Soria-Juan A, Lopez-Alba A, Lopez-Martinez N, Soria B. Costes directos de la diabetes mellitus y de sus complicaciones en España(Estudio SECCAID): Spain estimated cost Ciberdem-Cabimer in Diabetes. Av Diabetol. 2013;29(6):182-89.

28 The Diabetes Control and Complications Trial Research Group. The effect of intensive treatment of diabetes on the development and progression of long-term complications in insulin-dependent diabetes mellitus. N Engl J Med. 1993;329(14):977-86.

29 Nathan DM for the DCCT/EDIC Research Group. DCCT/EDIC 30th anniversary summary findings the diabetes control and complications trial/epidemiology of diabetes interventions and complications study at 30 years: overview. Diabetes Care. 2014;37(1):9-16.

30 Stratton IM, Adler Al, Neil HA, Matthews DR, Manley SE, Cull CA, et al. Association of glycaemia with macrovascular and microvascular complications of type 2 diabetes (UKPDS 35): prospective observational study. BMJ. 2000;321(7258):405-12.

31 UK Prospective Diabetes Study Group. Intensive blood glucose control with sulphonylureas or insulin compared with conventional treatment and risk of complications in patients with Type 2 diabetes (UKPDS33). Lancet . 1998; 352(9131):837-53.

32 Meigs JB. Epidemiology of type 2 diabetes and cardiovascular disease: translation from population to prevention: the kelly west award lecture 2009. Diabetes Care. 2010;33(8):1865-71.

33 Arrieta F, Iglesias P, Botet JP, Tébar FJ, Ortega E, Nubiola A, et al y Grupo de trabajo «Diabetes Mellitus y Enfermedad Cardiovascular» de la Sociedad Española de Diabetes. Diabetes mellitus y riesgo cardiovascular: Recomendaciones del grupo de trabajo diabetes mellitus y enfermedad cardiovascular de la Sociedad Española de Diabetes (SED 2015). Aten Prim. 2016;48(5):325-36.

34 Van der Heijden AA, Ortegon MM, Niessen LW, Nijpels G, Dekker JM. Prediction of coronary heart disease risk in a general, prediabetic, and diabetic population during 10 years of follow-up: Accuracy of the Framingham, SCORE, and UKPDS risk functions:the Hoorn Study. Diabetes Care. 2009;32(11):2094-8. 
35 Golay A, Lagger G, Chambouleyron M, Carrard I, Lasserre- Moutet A. Therapeutic education of diabetic patients. Diabetes Metab Res Rev. 2008;24(3):192-6.

36 Mulcahy K, Maryniuk M, Peeples M, Peyrot M, Tomky D, Weaver T, et al. Diabetes self-management education core outcomes measures. Diabetes Educ. 2013;29(5):768-803.

37 International Diabetes Federation Europe.2013. Access to quality medicines and medical devices for diabetes care in Europe. Disponible a: http://www.idf.org/regions/europe/ accesstodiabetescare [Consulta 27-05-2014]

38 Federation of European Nurses in Diabetes, Euradia, Primary Care Diabetes Europe, International Diabetes Federation Europe. The policy puzzle - is Europe making progress? International Diabetes Federation Europe. 2012. Disponible a: http://ec.europa.eu/health/major_chronic_diseases/docs/policy_puzzle_2011.pdf [Consulta 04-11-2016].

39 Valverde M, Jansà M, Harding E, Wait S. European Policy Action Network on Diabetes (EXPAND). Av Diabetol. 2014;30(4):118-9.

40 Navarro Despaigne DA. Aspectos psicológicos y sociales de la DM. A: Navarro Despaigne DA. Diabetes Mellitus, Menopausia y Osteoporosis. La Habana: Editorial Científico-Técnica; 2007. p. 110-3.

41 Pearce MJ, Pereira K, Davis E. The psychological impact of diabetes: a practical guide for the nurse practitioner. J Am Assoc Nurse Pract. 2013;25(11):578-83.

42 Pinhas-Hamiel O, Hamiel U, Levy-Shraga Y. Eating disorders in adolescents with type 1 diabetes: challenges in diagnosis and treatment. World J Diabetes. 2015; 6(3): 517-26. Disponible a: https://www.ncbi.nlm.nih.gov/pmc/articles/PMC4398907/ [Consulta 2303-2016]

43 Diaz L.Transtornos adaptativos en la Diabetes. Diabetis Avui. Associació Catalana de Diabetis 2006.. Disponible a: http://www.acdiabetis.org/d_avui/diabavui12.php [Consulta 03-04-2014]

44 Amurrio López de Gastiain LM, Limonero García JT. Concepto de duelo en estudiantes universitarios. Med Paliativa. 2007;14(1):14-9.

45 Fernández Liria A, Rodríguez Vega B. Intervenciones sobre problemas relacionados con el duelo para profesionales de Atención Primaria (I): el proceso del duelo. Medifam. 2002;12(3):100-7. Disponible a: :http://scielo.isciii.es/pdf/medif/v12n3/dinamica.pdf. [Consulta 03-04-2014] 
46 Grupo de estudio para el modelo de adaptación. Facultad de Enfermería. Universidad de la Sabana. Análisis de los conceptos del modelo d’adaptación de Callista Roy. Aquichan. 2002; 2(2):19-23. Disponible a: http://www.redalyc.org/articulo.oa?id=74120204 [Consulta: 23-03-2016]

47 Miaja M, Moral J. El significado psicológico de las cinco fases del duelo propuestas por Kübler-Ross mediante las redes semánticas naturales.Psicooncologia. 2013;10(1):109-30.

48 Gfeller R, Assal J-P. Developmental stages of patient aceptance in diabetes. A: Assal J-P, Berger M, Gay N, Canivet J, eds: Diabetes Education: how to improve Patient Education. International Congress Series 624. New York : Excerpta Medica, Elsevier Science Publishers; 1983. p. 207-18.

49 Lacroix A, Golay A, Assal JP. The process of accepting a chronic disease. What is the role of caregivers in management of these patients?. Schweiz Rundsch Med Prax. 1993;82(48):1370-2.

50 Folkman S, Lazarus RS, Dunkel-Schettel C, Delongis A, Gruen RJ. Dynamics of stressful encounter: cognitive appraisal, coping and encounter outcomes. J Pers Soc Psychol.1986; 50(5): 992-1003.

51 Gfeller R, Assal PH. Le vécu du malade diabètique avec sa maladie et avec son entourage. A : Catellier C, Tchobroutsky G, Assal JP, Lefebvre P, Renold A, Slama G, et al. eds. Le diabète Sucré. Québec: Èdisem; 1984. p. 221-32.

52 Shontz FC. Theories about the adjustment to having a disability. A: Cruichshank WM, ed. Psychology of exceptional children and youth $4 \underline{a}$ ed. Englewood Cliffs, N: Prentice-Hall Inc; 1980. p. 3-44.

53 Shontz FC. Physical disability and personality: theory and research.A: Stubbins J, ed. Social and psychological aspects of disability. Baltimore: University Park Press; 1983. p. 333-54.

54 Worden JW. El tratamiento del duelo. Asesoramiento psicológico y terapia. 2a ed. Barcelona: Paidós Ibérica; 2004.

55 Leventhal H, Meyer D, Nerenz DR. The common sense representation of illness danger. A: Rachman S, ed. Contributions to Medical Psychology. New York: Pergamon Press; 1980. p. 7-30.

56 Isla P, Moncho J, Guasch O, Torras A. Proceso d'adaptación a la diabetes mellitus tipo 1 (DM1). Concordancia con las etapas del proceso de duelo descrito por Kübler-Ross. Endocrinol Nutr. 2008;55(2):78-83. 
57 Lazcano M, Salazar BC. Estrés percibido y adaptación en pacientes con diabetes mellitus tipo 2. Aquichan. 2007; 7(1):77-84. Disponible a: http://www.redalyc.org/articulo. oa?id=74170107 [Consulta: 10- 05-2015]

58 Funnell MM, Anderson RM. Empowerment and self-management of diabetes. Clinical Diabetes. 2004; 22 (3):123-7.

59 World Health Organization (WHO). Adherence to long-term therapies: evidence for action. Switzerland. World Health Organization 2003. Disponible a: http://www.who.int/ chp/knowledge/publications/adherence_report/en/ [Consulta 15-06-2014].

60 Rubin RR, Peyrot M. Psychosocial problems ans interventions in diabetes: a review of the literature. Diabetes Care. 1992;15(11):1640-57.

61 American Diabetes Association. Standards of Medical Care in Diabetes 2015. Diabetes Care 2015;38(Suppl.1):S1-S2.

62 Bowes S, Lowes L, Warner J, Gregory JW. Chronic sorrow in parents of children with type-1 diabetes. J Adv Nurs. 2009; 65(5):992-1000.

63 Skovlund SE, Peyrot M, on behalf of the DAWN International Advisory Panel. The Diabetes Attitudes, Wishes, and Needs (DAWN) Program: a new approach to improving outcomes of diabetes care. Diabetes Spectrum. 2005;18(3):136-42.

64 Nicolucci A, Kovaks K, Holt RI, Comaschi M, Hermmans N, Ishii H, et al.; DAWN2 Study Group. Diabetes Attitudes, Wishes and Needs second study (DAWN2 ${ }^{\mathrm{TM}}$ ): cross-national benchmarking of diabetes-related psychosocial outcomes for people with diabetes. Diabet Med. 2013;30(7):767-77.

65 Kovacs Burns K, Nicolucci A, Holt RI, Willaing I, Hermanns N, Kalra S, et al; DAWN2 Study GroupDiabetes Attitudes, Wishes and Needs second study (DAWN2 ${ }^{\mathrm{TM}}$ ): cross-national benchmarking indicators for family members living with people with diabetes. Diabet Med. 2013;30(7):778-88.

66 Holt RI, Nicolucci A, Kovacs Burns K, Escalante M, Forbes A, Hermanns N, et al.; DAWN2 Study Group. Diabetes Attitudes, Wishes and Needs second study (DAWN2 ${ }^{\text {TM }}$ ): cross-national comparisons on barriers and resources for optimal care--healthcare professional perspective.Diabet Med. 2013;30(7):789-98.

67 Isla P. La educación para la salud en las diferentes etapas del cicló vital. A: Juvinyà Canal D, ed. Infermería i Salut comunitària. Girona: Documenta Universitària; 2005. p. 239-248. 
68 Pansier B, Schulz PJ. School-based diabetes interventions and their outcomes: a systematic literature review. J Public Health Res. 2015; 4(1):65-71.

69 Wiebe DJ, Berg CA, Korbel C, Palmer DL, Beveridge RM, Upchurch R, et al. Children's appraisals of maternal involvement in coping with diabetes: enhancing our understanding of adherence, metabolic control, and quality of life across adolescence. J Pediatr Psychol. 2005; 30 (2):167-78.

70 Gómez R, Díez-Espino J, Formiga F, Lafita J, Rodríguez L, González E, et al. Tratamiento de la diabetes tipo 2 en el paciente anciano. Med Clin. 2013; 140(3):134.e1-134.e12.

71 Vidre i mirall: els tres eixos vertebradors del Pla de Salut de Catalunya 2011-2015. Més salut i millor qualitat de vida (1). Ann Med. 2013; 96(2):59-64. Disponible a: http://www.raco. cat/index.php/AnnalsMedicina/article/viewFile/283335/371239 [Consulta 02-07-2016]

72 Breslow L. Health Measurement in the third era of health. Am J Public Health. 2006; 96(1):17-9.

73 World Health Organization (WHO). Constitución de la Organización Mundial de la Salud. Documentos básicos 2006. Suplemento de la 45a edición. Disponible a: http://www. who.int/governance/eb/who_constitution_sp.pdf [Consulta 02-07-2016]

74 World Health Organization (WHO). Frequently asqued questions 2015. Disponible a: http://www.who.int/suggestions/faq/en/ [Consulta 27-09-2015]

75 Alcántara G. La definición de salud de la Organización Mundial de la Salud y la interdisciplinariedad. Sapiens. Revista Universitaria de Investigación. 2008; 9(1):93-107. Disponible a: http://www.redalyc.org/pdf/410/41011135004.pdf [Consulta: 26-04-2015]

76 Breslow LA. Quantitative approach to the World Health Organization Definition of Health: physical, mental and social well-being. Int J Epidemiol. 1972; 1(4):347-55.

77 Terris M. Epidemiology as a Guide to Health Policy. Ann Rev Public Health. 1980; 1: 323-44.

78 Gol J. La salut. Xè Congrés de Metges i Biòlegs de Llengua Catalana. Perpinyà 1976. Acadèmia de Ciències Mèdiques de Catalunya i Balears. Ann Med. 1977; 61:1023-40.

79 Terris M. Approaches to an epidemiology on health. Am J Public Health. 1975; 67(10):1037-45.

80 World Health Organization. Regional Office for Europe. Health Promotion: a discussion document on the concept and principles. Disponible a: http://apps.who.int/iris/bitstream/10665/107835/1/E90607.pdf. [Consulta 26-12-15] 
81 Johnson DL, Ambrose SH, Bassett TJ, Bowen ML, Crummey DE, Isaacson JS, et al. Meanings of environmental terms. J Environ Qual. 1997; 26(3):581-9.

82 World Health Organization (OMS). Salud ambiental. Disponible a: http://www.who.int/ topics/environmental_health/es. [Consulta 20-09-2015].

83 World Healh Organization. Ottawa Charter for Health Promotion, 1986. Disponible a http://www.euro.who.int/__data/assets/pdf_file/0004/129532/Ottawa_Charter.pdf [Consulta 20-9-2015]

84 Ministerio de Sanidad, Servicios Sociales e Igualdad. Declaración de Yakarta sobre la promoción de la salud en el siglo XXI.. Disponible a: http://www.msssi.gob.es/profesionales/ saludPublica/prevPromocion/promocion/glosario/yakarta.htm [Consulta 20-9-2015]

85 Dubos R, Savage D, Schaedler R. Lasting effects of early environmental influences. Int J Epidemiol. 2005; 34(1):5-12.

86 Organización Mundial de la Salud (OMS). Glosario de Promoción de la Salud. Disponible a: http://www.msssi.gob.es/profesionales/saludPublica/prevPromocion/docs/glosario. pdf [Consulta 24-09-2015]

87 López-Moreno S, Garrido-Latorre F, Hernández-Ávila M. Reseña histórica de la epidemiología, desarrollo histórico de la epidemiología: su formación como disciplina científica. Rev Salud Públ Méx. 2000; 42(2):133-43.

88 Romero A, Ramírez J, López R, Cuevas G, De la Orta JF, Trejo LF, et al. Galeno de Pérgamo: pionero en la história de la ciencia que introduce los fundamentos científicos de la medicina. An Med (Mex). 2011; 56(4):218-25.

89 Medina-De la Garza CE, Koschwitz MC. Johann Peter Frank y la medicina social. Med Univer. 2011;13(52):163-8.

90 Actas oficiales de la Organización Mundial de la Salud (OMS). 22 Asamblea Mundial de la Salud. Boston, Massachusetts 8-25 de julio de 1969. Disponible a: http://apps.who.int/ iris/bitstream/10665/95269/1/Official_record177_spa.pdf [Consulta 24-09-2015]

91 Laframboise HL. Health policy: breaking the problem down into more namageable segments. Can Med Assoc J. 1973;108(3):388-91.

92 Lalonde M. A new perspective on the health of canadians 1974 . Disponible a: http:// www.phac-aspc.gc.ca/ph-sp/pdf/perspect-eng.pdf [Consulta 24-09-2015].

93 Lamata F. Una perspectiva de la política sanitaria 20 años después del informe Lalonde. Gac Sanit. 1994;8(43):189-94. 
94 Glass TA, McAtee MJ. Behavioral science at the crossroads in public health: extending horizons, envisioning the future. Soc Sci Med. 2006; 62 (7):1650-71.

95 Dahlgren G, Whitehead M. Policies and strategies to promote social equity in health. Stockholm: Stockholm Institute for Further Studies. 1991. Disponible a: https://core. ac.uk/download/files/153/6472456.pdf [Consulta 20-09-2015]

96 Organización Mundial de la Salud (OMS) Determinantes sociales de la salud. Disponible a: http://www.who.int/social_determinants/es/ [Consulta 24-09-2015]

97 Menendez Eduardo L. El modelo médico y la salud de los trabajadores. Salud Colectiva 2005 ; 1(1): 9-32. Disponible a: http://www.scielo.org.ar/scielo.php?script=sci_arttext\&pid=S1851-82652005000100002\&lng=es. [Consulta 18-10-2016]

98 Gómez Gascón T, Celtlin J. Medicina Familiar en España y otros países. A: Martín Zurro A, ed. Atención Primaria, principios, organización y métodos en medicina de família. 7ạ ed. Madrid: Elservier; 2014. p. 278-94.

99 Lizet R, Ceballos VP, Valenzuela SS, Sanhueza AO. Análisis crítico del paradigma positivista y su influencia en el desarrollo de l'enfermería. Index Enferm. 2012; 21(4):224-8. Disponible a:http://scielo.isciii.es/scielo.php?script=sci_arttext\&pid=S1132-12962012003300110 [Consulta 07-07-2016]

100 Engel GL. The need for a new medical model: a Challenge for Biomedicine. Science.1977; 196 (4286):129-36.

101 Montaner I, Foz G, Pasarin M.I. La salud: ¿un asunto individual?. AMF. 2012 ; 8(7):37482. Disponible a: http://amfsemfyc.com/web/downloader_articuloPDF.php?idar$\mathrm{t}=1015 \& i d=03$ NO_TODO_ES_CLINICA(3).pdf [Consulta 10-11-2016]

102 Beaulieu MD. Toward a patient-centred health care system. Can Fam Physician. 2013; 59(1):109.

103 Starfield B, Shi L, Macinko J. Contribution of primary care to health systems and health. Milbank Q. 2005; 83(3): 457-502.

104 Stewart M. Towards a global definition of patient centred care. BMJ. 2001; 322(7284):444-5

105 Sanjay K, Gwen H. The DAWN2 (second Diabetes, Attitudes, Wishes and Needs) study: Relevance to the UK. J Diabetes Nurs. 2014; 18 (6): 243-7.

106 Beverly EA, Hultgren BA, Brooks KM, Ritholz MD, Abrahamson MJ, Weinger K. Understanding physicians' challenges when treating type 2 diabetic patients' social and emotional difficulties. Diabetes Care. 2011; 34(5): 1086-8. 
107 Émile Durkheim. Educación y Sociología: la educación, su naturaleza y su papel. Barcelona: Península.1975. Disponible a: http://imgonix.planetadelibros.com/usuaris/libros_ contenido/arxius/28/27793_Educacion \%20y \%20sociologia.pdf [Consulta 26-04-2015]

108 Perea R. Educación para la salut, reto de nuestro tiempo. Educación XX1. 2001;4:1540. Disponible a: http://revistas.uned.es/index.php/educacionXX1/article/view/361/314 [Consulta 13-11-2016]

109 Isla P, López C, Caja C. Educació sanitaria. A: Caja López C, López Pisa R, eds. Enfermería Comunitaria III. Barcelona, Masson-Salvat 1993. p:185-92. Disponible a: http://www. montevideo.gub.uy/sites/default/files/concurso/materiales/anexo_14_-_enfermeria_ comunitaria_cap_17.pdf [Consulta 20-10-2016]

110 Echeverría B. Gestión de la competéncia d’acción profesional. 2002; 20(1):7-43. Disponible a: http://revistas.um.es/rie/article/viewFile/109501/104101 [Consulta 20- 10- 2016]

111 Martínez-Clares P, Martínez-Juárez M, Muñoz-Cantero JM. Formación basada en competencias en educación sanitaria: aproximaciones a enfoques y modelos de competencia 2008; 14(2):1-23. Disponible a: http://www.uv.es/RELIEVE/v14n2/RELIEVEv14n2_1.pdf [Consulta 20- 10- 2016]

112 Gavidia Catalán V, Rodes Sala MJ, Carratalá Beguer A. La educación para la salud: una propuesta fundamentada desde el campo de la docencia. Enseñanza de las Ciencias. 1993; 11(3): 289-95.

113 Salleras Sanmartí, L. Educación sanitaria: Principios, métodos y aplicaciones. Madrid: Díaz de Santos; 1990. Disponible a: https://books.google.es/books?id=23fCHlt_HdUC\&p$\mathrm{g}=\mathrm{PA} 51 \& \mathrm{hl}=\mathrm{ca} \&$ source=gbs_toc_r\&cad=3\#v=onepage\&q\&f=false [Consulta 26-04-2015].

114 Organización Mundial de la Salud (OMS). Comité d'expertos de la OMS. Planificación y evaluación de Servicios de Educación Sanitaria. Serie d'informes técnicos no 409. Ginebra 1969. Disponible a: http://apps.who.int/iris/bitstream/10665/38471/1/WHO_TRS_409_ spa.pdf [Consulta 02-01-2016]

115 Bucci R. Public Health History Corner.The far-sighted: Alessandro Seppilli. IJPH. 2011; 8(2): 217-20.

116 Organización Mundial de la Salud (OMS). Educación para la salud. Manual sobre Educación Sanitaria en Atención Primària de Salud. Disponible a: http://apps.who.int/iris/ handle/10665/38660 [Consulta 26-04-2015].

117 Yogeshkumar MR, Pateliya P. An introduction to modern models of teaching. IJRE. 2013; 2 (2):125-9. Disponiblea:http://raijmr.com/wp-content/uploads/2013/03/21_125-129-Yogeshkumar-P.-Pateliya.pdf [Consulta 26-04-2015] 
118 Isla P. Educación para la salud. A: Icart MT, Guardia J, Isla P, eds. Enfermería comunitaria II 2a ed. Barcelona: Masson; 2003. p. 283-91.

119 Trief PM, Xing D, Foster NC, Maahs DM, Kittelsrud JM, Olson BA, et al. Depression in adults in the T1D exchange clinic registry. Diabetes Care. 2014; 37(6):1563-72.

120 Diabetes Education Study Group (DESG). Working Group of the European Association for the Study of Diabetes. Basic curriculum for health professionals on diabetes therapeutic education. Report of a DESG Working Group. Geneve. Diabetes Education Study Group. 2001

121 Golay A, Lagger G, Chambouleyron M, Carrard I, Lasserre-Moutet A. Therapeutic education of diabetic patients. Diabetes Metab Res Rev. 2008; 24(3):192-6.

122 Assal JP, Jacquemet S, Morel Y. The added value of therapy in diabetes: the education of patients for self-management of their disease. Metabolism. 1997;46(Suppl.1):61-4.

123 Ferreira M, Rolin C, Fiore S, Farrias R, Gross JL, Bauermann C. Effect of different types of self-management education in patients with diabetes. Rev Assoc Med Bras. 2013;59 (4):400-5.

124 Assal JP, Mühlhauser I, Pernet A, Gfeller L. Jörgens V, Berguer M. Patient education as the basis for diabetes care in clinical practice and research. Diabetologia. 1985; 28(8):602-13.

125 Jarvey JN. Psychosocial interventions for the diabetic patient. Diabetes Metab Syndr Obes. 2015; 8:29-43.

126 World Health Organization. Regional Office for Europe. Copenhagen.Therapeutic Patient Education. Continuing Education Programmes for Health Care Providers in the Field of Prevention of Chronic Diseases. Report of a WHO working Group 1998. Disponible a: http://www.euro.who.int/__data/assets/pdf_file/0007/145294/E63674.pdf [Consulta 10-02-2017]

127 Haas L, Maryniuk M, Beck J, Cox CE, Duker P, Edwards L, et al. National Standards of diabetes self-manangement education and support. Diabetes Care. 2012; 35(11):2393-401.

128 Karamanou M, Koutsilieris M, Laios K, Marineli F, Androutsos G. Apollinaire Bouchardat (1806-1886): founder of modern diabetology. Hormones. 2014; 13(2):296-300.

129 Ronald Kahn C, Weir G, King G, Jacobson A, Smith R, Alan Moses A. Joslin's Diabetes Mellitus, $14^{\text {th }}$ ed. Boston. Lippincott Wilkins;2007.

130 Figuerola D, Reynals E. La educación de profesionales de la salud en diabetes. A: Figuerola D. Educación terapèutica de pacientes diabéticos. 4a ed. Barcelona: Masson; 2003. p 257-8. 
131 Valente Nabais JM. Care, education, protection-The Associação Protectora dos Diabéticos de Portugal goes from strength to diabetes. Diabetes Voice. 2012;57 (1):31-3.

132 Jackson JG. R.D. Lawrence and the formation of the Diabetic Association. Diabet Med. 1996; 13(1):9-22.

133 Maldonato A, Bloise D, Ceci M, Fraticelli E, Falluca F. Diabetes mellitus: lessons from patient education. Patient Educ Couns. 1995; 26(1-3): 57-66.

134 International Diabetes Federation. Italia. Roma: Associazione italiana per la difesa degli interessi dei diabetici. Disponible a: http://www.idf.org/membership/eur/italy/associazione-italiana-per-la-difesa-degli-interessi-dei-diabetici [Consulta 11-11-2016]

135 Carrasco i Formiguera R. Insulina: estudio fisiológico y clínico. Barcelona: Instituto Bioquímico Hermes; 1924.

136 Miller LV, Goldstein J. More efficient care of diabetic patients in a country hospital setting. N Engl J Med. 1972;286(26):1388-91.

137 American Association of Diabetes Educators. EEUU. Disponible a: https://www.diabeteseducator.org/about-aade [Consulta 11-11-2016]

138 Graber AL, Christman BG, Alogna MT, Davidson JK. Evaluation of diabetes patient-education programs. Diabetes. 1977;26(1):61-4.

139 Mühlhauser I, Bruckner I, Berger M, Cheţa D, Jörgens V, lonescu-Tîrgovişte C, et al. Evaluation of an intensified insulin treatment and teaching programme as routine management of type 1 (insulin-dependent) diabetes. The Bucharest-Düsseldorf Study. Diabetologia.1987;30(9):681-90.

140 Kronsbein P, Jörgens V, Mühlhauser I, Scholz V, Venhaus A, Berger M. Evaluation of a structured treatment and teaching programme on noninsulin-dependent diabetes. Lancet. 1988;17(8625):1407-11.

141 Jöergens V, Guesser M. Three years' experience after national introduction of teaching programs for Type II diabetic patients in Germany: how to train general practitioners. Patient Educ Couns. 1995; 26(1-3):195-202.

142 Peter-Riesch B, Assal JP. Teaching diabetic foot care effectively. J Am Podiatr Med Assoc.1997;87(7):318-20.

143 Assal JP, Albeanu A, Peter-Riesch B, Vaucher J. Cost of training a diabetes mellitus patient. Effects on the prevention of amputation. Diabet Metab.1993;19(suppl. 5):491-5. 
144 Assal JP. Cost effectiveness of diabetes education. Pharmacoeconomics.1995; 8 (Suppl. 1):68-71.

145 Assal JP, Berguer M, Canivet J. History and Aims of the Diabetes Education Study Group. International Congress Series No.624, Excerpta Medica, Amsterdam, 1982. p.3-7. Disponible a: http://www.desg.org/desg/about/history/ [Consulta 23-06-2016]

146 Maldonato A, Segal P, Golay A. The diabetes education study group and its activities to improve the education of people with diabetes in Europe. Patient Educ Couns. 2001;44(1):87-94.

147 Diabetes Education Study Group (DESG). Disponible a: http://www.desg.org/desg/teaching-tools/teaching-letters/ [Consulta 11-11-2016]

148 Diabetes Education Study Group of the European Association for the Study of Diabetes. Survival Kit: the five-minute Education Kit. Document for health care providers and patients. Diabet Med. 1995; 12(11):1022-43.

149 Diabetes Care and Research in Europe: the St. Vincent Declaration. Diabet Med. 1990; $7(4): 360$.

150 International Diabetes Federation (IDF). Consultative section on diabetes education. Disponible a: http://www.idf.org/education [Consulta 03-10-2015]

151 Clement S. Diabetes Self Management Education. (Technical Review). Diabetes Care. 1995,18(8):1204-14.

152 Weck M, Slesaczeck T, Paetzold H, Muench D, Nanning T, Gagern G, et al. Structured health care for subjects with diabetic foot ulcers results in a reduction of major amputation rates. Cardiovasc Diabetol. 2013; 12:45.

153 Chrvala CA, Sherr D, Lipman RD. Diabetes self-management education for adults with type 2 diabetes mellitus: a systematic review of the effect on glycemic control. Patient Educ Couns. 2016; 99(6): 926-43.

154 Boren SA, Fitzner KA, Panhalkar PS, Specker JE. Costs and benefits associated with diabetes education: a review of the literature. Diabetes Educ. 2009; 35(1):72-96.

155 American Association of Diabetes Educators: AADE7 Self-Care Behaviors. Diabetes Educ. 2008; 34(3):445-9.

156 Povey RC, Clark-Carter D. Diabetes and healthy eating: a systematic review of the literature. Diabetes Educ. 2007; 33(6):931-59. 
157 Deakin T, McShane CE, Cade JE, Williams RD. Group based training for self-management strategies in people with type 2 diabetes mellitus. Cochrane Database Syst Rev. 2005; 2:CD003417.

158 Norris SL, Lau J, Smith SJ, Schmid CH, Engelgau MM. Self-management education for adults with type 2 diabetes: a meta-analysis on the effect on glycemic control. Diabetes Care. 2002; 25(7): 1159-71.

159 Minet L, Moller S, Vach W, Wagner L, Henrisken J. Mediating the effect of self-care management intervention in type 2 diabetes: a meta-analysis of 47 randomised controlled trials. Patient Educ Couns. 2010;80(1): 29-41.

160 Juvinyà D, Figuerola D. Educación terapéutica en personas con diabetes. A: Figuerola D, ed. Manual de Educación Terapéutica en diabetes. Madrid: Diaz de Santos; 2013. p. 1-11.

161 Ibarra TX, Siles J. Competencia cultural, una forma humanizada de ofrecer cuidados de enfermería. Index Enferm . 2006. Disponible a: http://scielo.isciii.es/scielo.php?script=sci_arttext\&pid=S1132-12962006000300010 [Consulta 13-01-2017]

162 Diabetes Education Study Group of the European Association for the Study of Diabetes. The DESG Teaching letter. New developments in diabetes education: a call for a new task for the patient. Disponible a: http://www.Ides.unige.ch/publi/rech/teaching_letter.pdf [Consulta 12-02-2017]

163 Anderson RM, Funnell MM. The art of empowerment: stories and strategies for diabetes educators. 2a ed. USA: American Diabetes Association; 2005.

164 Anderson RM, Funnell MM. Patient Empowerment: myths and misconceptions. Patient Educ Couns. 2010; 79(3):277-82.

165 Anderson RM, Funnell MM. Patient empowerment: reflections on the challenge of fostering the adoption of a new paradigm. Patient Educ Couns. 2005; 57(2):153-7.

166 Haas L, Maryniuk M, Beck J, Cox CE, Duker P, Edwards L, et al. National Standards for Diabetes Self-Management Education and Support. Diabetes Care. 2012; 35(11):2393-401.

167 Valverde $M$, Vidal M, Jansà $M$. Técnicas didácticas en educación terapéutica aplicadas a la diabetes. Rev Enferm. 2012; 35(10):42-51.

168 Rickheim PL, Weaver TW, Flader JI, Kendall DM. Assessment of group versus individual diabetes education. Diabetes Care. 2002;25(2):269-74. 
169 Trento M, Gamba S, Gentile L. Grassi G, Misselli V, Morone G, et al; ROMEO investigators. Rethink Organization to improve education and outcomes (ROMEO): a multicenter randomized trial of lifestyle intervention by group care to manage type 2 diabetes. Diabetes Care. 2010;33(4):745-7.

170 Sicuro J, Bondonio P, Charrier L, Berchialla P, Cavallo F, Porta M, et al. Cost analysis of group versus usual care in patients with type 2 diabetes in the ROMEO clinical trial. Nutr Metab Cardiovasc Dis. 2013;23(2):13-4.

171 Porta M, Trento M. ROMEO: rethink organization to improve education and outcomes. Diabet Med. 2004;21(6):644-5.

172 Deakin TA, McShane CE, Cade JE, Williams R. Group based training for self-management strategies in people with type 2 diabetes mellitus. Cochrane Database Syst Rev. 2005;18(2):CD003417.

173 Valverde $M$, Vidal $M$, Jansà $M$. Teorías y modelos que facilitan un aprendizaje significativo. Curso DIANA ADVANCED. Capítulo 11. Bayer Health Care

174 Kaufman N. Internet and information technology use in treatment of diabetes. Int J Clin Pract Suppl. 2010;(166):41-6.

175 Pal K, Eastwood SV, Michie S, Farmer A, Barnard ML, Peacock R, et al. Computer-Based interventions to improve self-management in adults with type 2 diabetes: a systematic review and meta-analysis. Diabetes Care. 2014;37(6):1759-66.

176 Pereira K, Phillips B, Johnson C, Vorderstrasse A. Internet delivered diabetes self-management education: a review. Diabetes Technol Ther. 2015; 17(1): 55-63.

177 International Standards for education of diabetes health professionals. International Diabetes Federation 2009 Disponible en: http://www.idf.org/webdata/docs/INTNL-STANDARDS-EN.pdf [Consulta 14-05-2016]

178 Department of Health and Diabetes UK. Structured Patient Education in Diabetes: Report from the Patient Education Working Group . London (UK). Disponible a: http://www. plymouthdiabetes.org.uk/resources/147.pdf [Consulta: 05-04-2015]

179 Haute Autorité de Santé (HAS). Éducation thérapeutique du patient: Définition, finalités et organisation 2007. Disponible a: http://www.has-sante.fr/portail/jcms/c_1241714/fr/ education-therapeutique-du-patient-etp [Consulta 05-04-2015] 
180 Haas L, Maryniuk M, Beck J, Pharm D, Cox CE, Duker P, et al. National Standards for diabetes self-management education and support. Diabetes Care. 2014; 37 (Suppl. 1):S144-S153.

181 Jansà M, Galindo M, Valverde M, Yoldi C, Vidal M, Isla P. Posicionamiento de la Sociedad Española de Diabetes (SED) sobre el perfil curricular y profesional de los profesionales de enfermería expertos en la atención de las personas con diabetes, sus familiares o cuidadores. Av Diabetol. 2014;30(5):150-5.

182 Allen N. The history of diabetes nursing, 1914-1936. Diabetes Educ. 2003; 29(6): 976, 979-84.

183 Dunning T. El papel complejo y en constante evolución de los educadores diabéticos. Diabetes Voice. 2007 (volumen especial) ;52: 9-11. Disponible a: http://www.idf.org/sites/ default/files/attachments/article_550_es.pdf [Consulta 10-11-2016]

184 Joslin EP. The treatment of diabetes mellitus: with observations upon the disease based upon one thousand cases. Lea and Febinger. Philadelphia; 1917.

185 Dunning PL. The diabetes educator: evolution of a nurse specialist. Practical Diab. 1992; $9(6): 220-2$.

186 Joslin Diabetes Center. From «wandering nurse» to Certfied Diabetes Educator. Joslin Diabetes Center. Disponible a: https://www.joslin.org/about/from_wandering_nurse_ to_certified_diabetes_educator.html. [Consulta 05-04-2014]

187 Georgopoulos BS, Christman S. The clinical nurse specialist: a role model. Am J Nurs. 1970; 70(5): 1030-9.

188 Mckinnon M. Diabetes nursing a personal perspective of the last 50 years. Br J Diabetes Vasc Dis. 2002;2(6):464-7.

189 Forbes A. Progressing diabetes nursing in Europe: the next steps. Eur Diab Nursing. 2011; 8(1):8-10. Disponible a: http://onlinelibrary.wiley.com/doi/10.1002/edn.166/epdf [Consulta 19-11-2016]

190 Funnell MM, Brown TL, Childs BP, Haas LB, Hosey GM, Jensen B, et al. National Standards for diabetes self-management education. Diabetes Care. 2011; 34 (Suppl. 1):89-96.

191 Yoldi C. Formación en educación terapéutica en diabetes: ¿Qué tenemos y qué nos falta?. Av Diabetol. 2011; 27(3): 100-5. 
192 National Certification Board for Diabetes Educators. American Association of Diabetes Educators. 2016. Disponible a: https://www.diabeteseducator.org/education-career/ certification/bc_adm [Consulta 19-11-2016]

193 Valentine V, Kulkarni K, Hinnen D. Evolving Roles: from diabetes educators to advanced diabetes managers. Diabetes Educ. 2003; 29(4): 598-610.

194 The Canadian Diabetes Educator Certification Board. Disponible a: http://www.cdecb. ca/what-is-a-cde/maintenance-by-cp/. [Consulta 23-03-2016]

195 Foundation of European Nurses in Diabetes (FEND). Disponible a: http://www.fend.org/ projects/fend-endcup [Consulta 23-03-2016]

196 Ministerio de Sanidad, Servicios Sociales e Igualdad. Estrategia en Diabetes del Sistema Nacional de Salud. Actualización 2012. Madrid: Ministerio de Sanidad, Servicios Sociales e Igualdad; 2012 . Disponible en: http://www.aecosan.msssi.gob.es/AECOSAN/docs/documentos/nutricion/observatorio/estrategia_en_diabetes_del_sistema_nacional_de_ salud_2012.pdf [Consulta 23-03-2016].

197 Grupo de Trabajo Guías Clínicas y Consensos de la Sociedad Española de Diabetes. Perfil profesional del educador de pacientes con diabetes. Av Diabetol. 2012; 28(2):38-47.

198 Davis R, Turner E, Hicks D, Tipson M. Developing an integrated career and competency framework for diabetes nursing. J Clin Nurs. 2008; 17(2): 168-74.

199 Davies M, Davis R. Role of the hospital diabetes specialist nurse: perception versus reality. J Diabetes Nurs. 1998; 2(4): 105-7.

200 Callaghan L. Advanced nursing practice: an idea whose time has come. J Clin Nurs. 2008; 17(2):205-13.

201 Gurzick M, Kesten KS. The impact of clinical nurse specialists on clinical pathways in the application of evidence-based practice. J Prof Nurs. 2010;26 (1):42-8.

202 Castledine G. New Nursing roles: deciding de future for Scotland. 2004. Scottish Goverment. Disponible a: http://www.gov.scot/Publications/2004/04/19201/35586 [Consulta 19-09-2016]

203 Hill KM, Ellsworth-Wolk J, DeBlase R. Capturing the multiple contributions of the CNS role: a criterion-based evaluation tool. Clin Nurs Spec. 1993;7(5):267-73.

204 Davis EA. Factors influencing the implementation of the CNS role in a private practice. Clin Nurs Spec. 1994;8(1):42-7. 
205 Mazurek B, Gallangher-Ford L, English L, Fineout- Overholt E. The establishment of evidence-based practice competencies for practicing registered nurses and advanced practice nurses in real-word clinical settings: proficiences to improve health care quality, realiability, patient outcomes and costs. Worldviews Evid-Based Nurs. 2014; 11(1): 5-15.

206 Sastre-Fullana P, De Pedro-Gómez JE, Bennasar-Veny M, Fernández-Domínguez JC, Sesé-Abad AJ, Morales-Asencio JM. Consenso sobre competencias para la enfermería de práctica avanzada en España. Enferm Clin. 2015; 25(5):267-75.

207 Kilpatrick K, Lavoie-Tremblay M, Ritchie JA, Lamothe L, Doran D, Rochefort C. How are acute care nurse practitioners enancing their roles in healthcare teams?. A descriptive multiple-case study. Int J Nurs Stud. 2012; 69(1):205-17.

208 Bousfield C. A phenomenological investigation into the role of the clinical nurse specialist. J Adv Nurs. 1997;25(2):245-56.

209 International Council of Nurses. Nurse Practitoner/ Advanced Practice Nurse: definition and characteristics. Disponible a: https://international.aanp.org/Practice/APNRoles [Consulta 19-11-2016]

210 Davis B, Hughes AM. Clarification of advanced nursing practice: characteristics and competencies. Clin Nurse Spec.1995; 9(3): 156-60.

211 Llana S, Coates V, Poulton B. Survey: role components, functions and activities of the DSN. J Diabetes Nurs. 2001; 5(6): 181-7.

212 Cattini P, Knowles V. Core competencies for Clinical Nurse Specialist: a usable framework. J Clin Nurs. 1999; 8(5): 505-11.

213 Llana S, Coates V, Poulton B. Exploring the relevance of the DSN role to the Greek healthcare setting. J Diabetes Nurs. 2004; 8(4): 145-51.

214 National Association of Clinical Nurse Specialist . Philadelphia Disponible a: http://nacns. org/about-us/what-is-a-cns/ [Consulta 19 -11- 2016]

215 National Association of Clinical Nurse Specialist. Clinical Nurse Specialist Core Competences 2006-2008. Disponible a: http://www.nacns.org/docs/CNSCoreCompetenciesBroch.pdf [Consulta 19-11-2016]

216 Sparacino, PSA. The clinical nurse specialist. A: Hamric AB, Spross JA, Hanson CM, eds. Advanced practice nursing: an integrative approach. 3rd ed. St. Louis: Elsevier; 2005. p. 415-46 
217 Smith AC. Role ambiguity and role conflict in nurse case managers: an integrative review. Prof Case Manag. 2011;16(4):182-96.

218 Donald F, Bryant-Lukosius D, Martin-Misener R, Kaasalainen S, Kilpatrick K, Carter N, et al. Clinical nurse specialists and nurse practitioners: title confusion and lack of role clarity. Nurs Leadersh (Tor Ont). 2010;23(2010):189-201.

219 Lloyd-Jones ML. Role development and effective practice in specialist and advanced practice roles in acute hospital settings:systematic review and metasyntesis. J Adv Nurs. 2005;49(2):191-209.

220 Disch J, Walton M, Barnsteiner J. The role of the clinical nurse specialist in creating a healthy work environment. AACN Clin Issues. 2001;12(3):345-55.

221 Middleton N. The role of the DSN in providing quality diabetes care within constrained finance. J Diabetes Nurs. 2012; 16(5):188-98.

222 Muller AC, Hujcs M, Dubendorf P, Harrington PT. Sustainin excellence: clinical nurse specialist practice and magnet designation. Clin Nurs Spec. 2010;24(5):252-9.

223 Boström E, Isaksson U, Lundman B, Sjölander A E, Hörnsten Å. Diabetes specialist nurses' perceptions of their multifaceted role. Eur Diab Nursing. 2012; 9(2): 39-44b.

224 Forbes A, While A. The nursing contribution to chronic disease management: a discussion paper. Int J Nurs Stud. 2009; 46(1): 119-30.

225 Flannery C, McHugh S, Murphy K, BuckleyCM, Thackeray K, O'Connor A, et al. The role of the diabetes nurse specialist (DNS) in the management of patients with diabetes: $a$ systematic review. J Epidemiol Community Health. 2015; 69(Suppl. 1): A58.

226 Malachy O'Hagan M, Harvey JN, and for the Brecon Group Glycemic Control in Children With Type 1 Diabetes in Wales. Influence of the pediatric diabetes specialist nurse. Diabetes Care. 2010; 33(8):1724-26.

227 Jurado J, García JM, Gich I, Pou JM. The impact of previous diabetes education level on the control of cardiovascular risk factors in type 2 diabetic patients at the start of the north Catalonia diabetes study. Int J Diabet Metab. 2006;14(1):61-7.

228 Loveman E, Royle P, Waugh N. Specialist nurses in diabetes mellitus. Cochrane Database Syst Rev. 2003; (2): CD003286.

229 James J. Diabetes specialist nursing in the UK: the judgement call?. A review of existing literature. Eur Diab Nursing. 2011; 8(3): 108-13. 
230 Valverde $\mathrm{M}$, Jansà M, Vidal M, Isla P, Vrijhoef B. Estudio Europeo de Enfermeras en Diabetes (SEND): resultados de un cuestionario administrado a enfermeras en diabetes de ocho países europeos. Av Diabetol. 2010;26 (suppl. 2): 12

231 Laurant M, Reeves D, Hermens R, Braspenning J, Grol R, Sibbald B. Substitution of doctors by nurses in primary care. Cochrane Database Syst Rev. 2005; 18(2): CD001271

232 Vrijhoef HJM, Diederiks JPM, Spreeuwenberg C, Wolffenbuttel BHR. Substitution model with central role for nurse specialist is justified in the care for stable type 2 diabetic outpatients. J Adv Nurs. 2001; 36(4):546-55.

233 CatSalut. Servei Català de la Salut. Generalitat de Catalunya. Disponible a: http://catsalut.gencat.cat/ca/ciutadania/acces-sistema-salut/guiadus/canals/atencio-primaria/ [Consulta 20-11-2016]

234 Isla P, Castella E, Insa R, López C, Icart T, Blanco M. Proporción de carga asistencial generada por la diabetes mellitus en las consultas de enfermería de atención primaria de salud. Endocrinol Nutr. $2000 ; 54(1): 2-9$.

235 Ancochea L. La enfermera y el cambio en el concepto de cuidar en atención primaria. A: Cuidar: arte y ciencia. Reflexiones sobre la Enfermería del siglo XXI. 1a ed. Barcelona: UIC Publicaciones; 2012. p. 185-90.

236 Mariné $C$. Les infermeres especialitzades en atenció primària no poden exercir per falta de places. El diari de la sanitat. Disponible a: http://diarisanitat.cat/les-infermeres-especialitzades-en-atencio-primaria-no-poden-exercir-per-falta-de-places/ [Consulta 1012-2016].

237 Generalitat de Catalunya. Departament de Salut. Aportació de la infermera a l'Atenció Primària de Salut. Disponible a: http://canalsalut.gencat.cat/web/.content/home_canal_salut/professionals/recursos/sistemes_dinformacio_catalegs_i_classificacions/documents/aportacio_infer_ap2012.pdf [Consulta 20-11-2016]

238 Generalitat de Catalunya. CatSalut. Servei Català de la Salut. Atenció especialitzada i hospitalaria d'aguts. Disponible a: http://catsalut.gencat.cat/ca/ciutadania/serveis-atencio-salut/quins-serveis-ofereix-catsalut/atencio-especialitzada-hospitalaria-aguts/ [Consulta 20-11-2016]

239 Ministerio de la Presidencia. Real Decreto 450/2005, de 22 de abril, sobre especialidades de enfermería. Disponible a: https://www.boe.es/diario_boe/txt.php?i$d=B O E-A-2005-7354$ [Consulta 16-10-2016] 
240 Valverde M, Jansà M, Vidal M, Isla P, Vrijhoef B. Estudio Europeo de Enfermeras en Diabetes (SEND). Subanálisis de los resultados en España. Av Diabetol. 2011;27: 24

241 Delgado García G. Conceptos y metodología de la investigación histórica. Rev Cubana Salud Pública 2010; 36(1): 9-18. Disponible a: http://www.redalyc.org/articulo. oa?id=21416134003 [Consulta 25-06- 2015];

242 Ribot Català C, Fernández-Tenllado M.A. Investigación cualitativa en atención primaria. Una experiencia con entrevistas abiertas. Aten Prim. 2000; 25(5): 343-8.

243 Saavedra E, Castro A. La investigación cualitativa, una discusión presente. LIBERABIT (Perú). 2007; 13:63-9.

244 Vanegas BC. La investigación cualitativa: un importante abordaje del conocimiento para enfermería. Rev Col Enf. 2011; 6(6): 128-42.

245 Anadón M. La investigación llamada "cualitativa": de la dinámica de su evolución a los innegables logros y los cuestionamientos presentes. Invest Educ Enferm. 2008;26(2):198-211.

246 Villalbi JR, Maldonado R. La alimentacion de la poblacion en España desde la posguerra hasta los años ochenta: una revisión crítica de las encuestas de nutrición. Med Clin. 1988; 90(3):127-30.

247 Micaló T, Esmatjes E, Bergua M, Figuerola D. La cetoacidosis diabética en un Hospital General en Cataluña: situación clínica inicial, evolución en las primeras 24 horas y revisión crítica de un protocolo terapéutico. Med Clin. 1983; 80(19): 830-5.

248 Figuerola D. La enseñanza a pacientes diabeticos: una inversión rentable. Med Clin. 1983; 80(13):582-4.

249 Cabezas JA. La Lucha antidiabética de la Cruz Roja Española. Diari ABC, 6-2-1972, pàg 49. Disponible a: http://hemeroteca.abc.es/nav/Navigate.exe/hemeroteca/madrid/ abc/1972/02/06/049.html [Consulta: 08-06-2016]

250 Col-legi de Metges. Galeria de Metges Catalans. 2015. Disponible a: http://www.galeriametges.cat/galeria-fitxa.php?icod=GLL [Consulta 08-06-2016]

251 Cruz Roja Española. Lucha antidiabética de la Cruz Roja Española. Diari Los sitios 1-61973, pag- 4. Disponible a: http://www.girona.cat/sgdap/cat/premsa.php [Consulta 0806-2016]

252 Pla J. M. Colonias de vacaciones para niños diabèticos. Med Clin. 1985;85(1):19-20. 
253 Diari Los Sitios. Inauguración del Servicio de Endocrinología y Nutrición. Diari Los Sitios, 3 maig 1975, pàg-5 . Disponible a: http://www.girona.cat/sgdap/cat/premsa.php [Consulta 08-06-2016]

254 Diari La Vanguardia. Charlas para diabéticos y sus familiares. Diari La Vanguardia, 2410-1979: p.28 . Disponible a: http://hemeroteca.lavanguardia.com/preview/1979/10/24/ pagina-28/33442599/pdf.html [Consulta: 08-06-2016]

255 Diari La Vanguardia. Hoy Dia Mundial de la Salud. Diari La Vanguardia, 07-04-1971: p.23. Disponible a: http://hemeroteca.lavanguardia.com/preview/1972/05/25/pagina-23/34268513/ pdf.html?search=Dia\%20mundial\%20de\%20la\%20salud\%201971 [Consulta 06-01-2017].

256 Generalitat de Catalunya. ORDRE de 18 de març de 1983, de creació del Consell Assessor sobre la Diabetis a Catalunya. Diari oficial de la Generalitat de Catalunya. Disponible a: http://dogc.gencat.cat/ca/pdogc_canals_interns/pdogc_resultats_fitxa/?language=ca_ES\&originParam=cercaSimple\&newLang=ca_ES\&action=searchprint\&searchTypeParam $=$ simple \&portalld $=2 \&$ submit. $x=7 \&$ submit. $y=14 \&$ submit $=$ Cercar\&text $=D O G C+n \%$ FAm. $+330-+18 \% 2 F 03 \% 2 F 1983 \&$ txttext=DOGC+n\%FAm.+330-+18\%2F03\%2F1983\&txtonlyTitle=. [Consulta 18-12-16]

257 Asociación de Diabéticos Catalonia. Jornada de información para diabéticos. Diari La Vanguardia, 16-4-1980: p. 28. Disponible a: http://hemeroteca.lavanguardia.com/preview/1980/04/16/pagina-28/32893258/pdf.html [Consulta: 08-06-2016]

258 Asociación de Diabéticos Catalonia. II Conferencias para diabéticos. Diari La Vanguardia 19-4-1980: pàg 30. Disponible a: http://hemeroteca.lavanguardia.com/preview/1980/04/19/pagina-30/32903786/pdf.html [Consulta: 08-06-2016]

259 Asociación de Diabéticos Catalonia. El diabético no es un enfermo. Diari La Vanguardia 125- 1981: p. 33. Disponible a: http://hemeroteca.lavanguardia.com/preview/1981/05/12/ pagina-33/32923421/pdf.html [Consulta: 08-06-2016]

260 Asociación de Diabéticos Catalonia. Jornada sobre nutrición para diabéticos en el Club Catalonia. Diari La Vanguardia 23-05-1984: p. 26 Disponible a: http://hemeroteca.lavanguardia.com/preview/1984/05/23/pagina-26/32834068/pdf.html [Consulta: 08-06-2016]

261 Asociación de Diabéticos Catalonia. Más de sesenta mil diabéticos hay actualmente en Cataluña. Diari La Vanguardia 25-10-1984: p. 22. Disponible a: http://hemeroteca.lavanguardia.com/preview/1984/10/25/pagina-22/32850576/pdf.html [Consulta: 08-06-2016]

262 Asociación de Diabéticos Catalonia. Más asisténcia para diabéticos. Diari La Vanguardia 25-10-1984: p. 64. Disponible a: http://hemeroteca.lavanguardia.com/preview/1984/10/25/pagina-64/32850618/pdf.html [Consulta: 08-06-2016] 
263 Asociación de Diabéticos Catalonia. Información y asesoramiento al diabético. Diari La Vanguardia 5-10-1985: p. 50. Disponible a: http://hemeroteca.lavanguardia.com/preview/1985/10/05/pagina-50/32860968/pdf.html [Consulta: 08-06-2016]

264 Asociación de Diabéticos Catalonia. Carnet para diabéticos. Diari La Vanguardia 09-011986: p. 49. Disponible a: http://hemeroteca.lavanguardia.com/preview/1986/01/09/ pagina-49/32875677/pdf.html [Consulta:08-06-2016]

265 Figerola D, Reynals E, Micaló T, Levy I, Gomis R. Resultados a largo plazo de un programa de educación diabetológica. Med Clin. 1988; 91(14):525-9.

266 Costa B, Belmonte MA, Huguet R, Richart C. Educación diabetológica en un hospital general de Cataluña: metodología e indicadores de efectividad a corto plazo. Rev Clin Esp. 1989; 185(2):82-90.

267 Binimelis J, Villabona P, Ubeda J, Codina M, de la Torre W, de Leiva A. Impacto de un programa educativo en el control metabólico y en el coste sanitario de la diabetes mellitus. Med Clin. 1986; 87(6):221-3.

268 Trilla $M$, Mundet $X$, Bundó $M$, Rodríguez J. La educación sanitaria del diabético tipo II. Papel de la atención primaria. Med Clin. 1987; 89(3):130.

269 Costa B, Pérez C, Alamo C, Olesti M, Boqué N, Gomis T. Control de calidad en educación diabetológica. Aptitud y actitud del educador: una aproximación autocrítica. Endocrinología. 1990; 37(6):216-21.

270 Jurado J, Caula JA, Hernández JM, Juvinyà D, Pou JM. La supresión de la educación especializada empeora el control metabólico en diabetes tipo 2. Aten Prim. 2009; 41(12):681-7.

271 Chast F. Apollinaire Bouchardat, pharmacist, nutritionist. Ann Pharm Fr. 2000; 58 (Suppl. 6):S435-S542.

272 Dall'Olio G. Diabete e Laboratorio nell'Ottocento II "paraglucoso". RIMeL/ IJLaM. 2007; 3:218-21.

273 Álvarez Aldana D, Rodríguez Bebert Y. Doctor Octavio Montoro y los primeros casos de diabetes tratados con insulina en Cuba. Rev Cubana Endocrinol. 2003;14(2): Disponible a:http://scielo.sld.cu/scielo.php?script=sci_arttext\&pid=S1561-29532003000200008 [Consulta 10-02-2017]

274 Joslin EP. A Diabetic Manual. 2nd ed. New York: Lea \& Febiger ;1919. p.110. 
275 Departament de sanitat i asistencia social. Decret 7 de gener de 1980 pel qual s'aprova el Mapa Sanitari de Catalunya. Diari oficial de la Generalitat de Catalunya, 07-03-1980. Disponible a: http://dogc.gencat.cat/ca/pdogc_canals_interns/pdogc_sumari_del_dogc/?numDOGC=49\&anexos=1\# [Consulta 10-02-2017]

276 Cardaci D. Las ciencias sociales y la formación en educación para la salud. Educ Med Salud. 1992; 26(1):115-27.

277 Seppilli A, Modolo MA. Educazione Sanitaria. Roma, II: Pensiero Scientifico Editore; 1985.

278 Catellier C, Tchobroutsky G; Assal JPH, Lefebre P, Renold A, Slama G, et al. Le Diabète Sucrè. Quebec: Edisem, 1984.

279 Rodriguez Gómez S, Camacho Bejarano R, Lima Serrano M, Padín López S, Gómez Salgado J. Soñar con otros mundos. Enferm Clin. 2015; 25(6):291-5.

280 Celma Vicente M, Acuña Delgado A, Influencia de la feminización de la enfermería en su desarrollo profesional. Revis Antropol Exp. 2009; 9(9):119-36. Disponible a: http://revista.ujaen.es/rae [Consulta 27-01-2016]

281 Isla P. Educación terapèutica en diabetes. ¿Dónde estamos?. Rev Rol . 2011;34(6):32-8.

282 Funnell MM, Brown TI, Childs BP, Haas LB, Hosey GM, Jensen B, et al. National Standards for diabetes self-management education. Diabetes Care. 2008; 31 (Suppl. 1): S97-104.

283 Peyrot M, Rubin RR, Funnell MM, Siminerio LM. Access to diabetes self-management education: results of national surveys of patients, educators, and physicians. Diabetes Educ. 2009; 35(2): 246-63.

284 Peyrot M, Rubin MM, Lauritzen T, Snoek FJ, Matthews DR, Skovlund SE. Psychosocial problems and barriers to improved diabetes management: results of the cross-national Diabetes Attitudes, Wishes and Needs (DAWN) Study. Diabet Med. 2005; 22(10):1379-85.

285 Moser A. van der Bruggen H, Widdershven G, Spreeuwenberg C. Self management of type 2 diabetes mellitus: a qualitative investigation from the perspective of participants in a nurse-led, shared-care programme in the Netherlands. BMC Public Health. 2008; 8:91.

286 Loveman E, Frampton GK, Clegg AJ. The clinical effectiveness of diabetes education models: a systematic review. Health Technol Assess. 2008; 12(9): 1-6.

287 Shah BR, Hux JE, Laupacis A, Zinman B, Van Walraven C. Clinical inertia in response to inadequate glycemic control:do specialists differ from primary care physicians?. Diabetes Care. 2005; 28(3):600-6. 
288 Anderson RM, Funnell MM. Patient empowerment: reflections on the challenge of fostering the adoption of a new paradigm. Patient Educ Couns. 2005:57(2):153-7.

289 DECRET 84/1985, de 21 de març, de measures per a la Reforma de l'Atenció Primària de Salut a Catalunya (Correcció d'errada en el DOGC núm 552, p.2001, de 19-6-1985) DOGC núm 527 publicat el 10-4-1985. Disponible a: http://dogc.gencat.cat/ca/pdogc_canals_interns/pdogc_resultats_fitxa/?documentld=237664\&action=fitxa [Consulta 1002-2017]

290 Kuusisto J, Mikkanen L, Pyorala K, Laasko M. NIDDM and its metabolic control predict coronary heart disease in elderly subjects. Diabetes. 1994; 43(8):960-7.

291 Universitat de Barcelona. Máster para la Atención y Educación de las personas con Diabetes Disponible a: http://www.ub.edu/web/ub/ca/estudis/oferta_formativa/master_ universitari/fitxa/B/M280G/index.html [Consulta 27-01-2017]

292 International Diabetes Federation. Diabetes education modules. Educational resources supporting the content of the International Curriculum for Diabetes Health Professional Education. Bélgica; 2011. Disponible a: https://www.idf.org/webdata/docs/Education\%20modules\%20Leaflet.pdf [Consulta 27-01-2017]

293 Mensing C, Boucher J, Cypress M, Weinger K, Mulcahy K, Barta P, et al. National Standards for Diabetes Self-Management Education. Task Force to Review and Revise the National Standards for Diabetes-Self-Management Education Programs. Diabetes Care.2000; 23(5):682-9.

294 Barlow S, Crean J, Heizler A, Mulcahy K, Springer J. Diabetes educators: assessment of evolving practice. Diabetes Educ. 2005; 31(3):359-72.

295 Parro A, Santiago MI, Abraira V, Aré Jula JL, Díaz A, Gandarillas A, et al. Control de la diabetes mellitus en población adulta según las características del personal de enfermería de atención primaria de la Comunidad de Madrid: análisis multinivel. Rev Esp Salud Pública. 2016; 90: 1-13.

296 Boström E, Hörnsten A. Lundman B, Stenlund H, Isaksson U. Role clarity and role conflict among Swedish diabetes specialist nurses. Prim Care Diabetes. 2013; 7 (3): 207-12.

297 James J. Diabetes specialist nursing in the UK: the judgement call?. A review of existing literature. Pract Diab Int. 2011; 27(6): 248-53.

298 Annersten M, Frid A, Dahlberg G, Högberg, Apelqvist J. Structured diabetes education in Sweden. Pract Diabet Int. 2006; 23(3):1-4. 
299 Jurado Campos J. La infermeria d'atenció primària en l'atenció als problemes del peu en la diabetis tipus 2 a Catalunya. [tesi doctoral]. Universitat de Girona; 2009.

300 Lawrence A. Nathan A, La Fontaine J, Cory L, Agbor N, Boulton A. Diabetic foot prevention: a neglected opportunity in high risk patients. Diabetes Care. 2010; 33(7):1460-2.

301 Rubio JA, Aragón-Sánchez J, Lázaro-Martínez JL, Cruz M, Mauricio D, Antolín JB. et al. On behalf of the Spanish Group on the Diabetic Foot. Diabetic foot units in Spain: knowing the facts using a questionnaire. Endocrinol Nutr. 2014;61(2):79-86.

302 Viadé J. El papel del podólogo en la atención al pié diabético. Angiología. 2015;67(6):483-7.

303 Galindo M, Jansà M, Menéndez E, en nombre del Grupo DAWN2 España. Educación terapéutica y autocuidado: resultados del estudio observacional transversal Diabetes Attitudes, Wishes and Needs 2 (DAWN2) en España. Endocrinol Nutr. 2915;62(8):391-9.

304 Richardson GC, Derouin AL, Vorderstrasse AA, Hipkens J, Thompson JA. Nurse practitioner management of Type 2. Diabetes Perm J. 2014 ;18(2):e134-e40.

305 Mira J J, Orozco D, Sánchez M, Sánchez J. Evaluación de la satisfacción de los pacientes crónicos con los dispositivos de telemedicina y con el resultado de la atención recibida. Programa ValCrònic. Aten Primaria. 2014;46(Suppl. 3):16-23.

306 Sánchez-Garrido R, Rodríguez MI, Molina MP, Martínez JL, Martínez L, Escobar JL. Análisis de la educación diabetológica y perfiles de pacientes con diabetes mellitus tipo 2 en un área sanitaria rural. Rev Calidad Asistencial. 2005;20:14-8.

307 Holt RI, Nicolucci A, Kovacs K, Lucisano G, Skovlund SE, Forbes A, et al. Correlates of psychological care strategies for people with diabetes in the second Diabetes Attitudes, Wishes and Needs (DAWN2) study. Diabet Med. 2016;33(9):1174-83.

308 Siminerio LM, Funnell MM, Peyrot M, Rubin RR. US nurses' perceptions of their role in diabetes care: results of the cross-national Diabetes Attitudes Wishes and Needs (DAWN) study. Diabetes Educ. 2007;33(1):152-62.

309 James J, Gosden C, Winocout P, Walton C, Nagi D, Turner B, et al. Diabetes specialist nurses and role envolvement: a survey by Diabetes UK and ABCD of specialists diabetes services. Diabet Med. 2009; 26(5): 560-5.

310 Boletin Oficial del Estado. Real Decreto 954/2015 de 23 de octubre, por el que se regula la indicación, uso y autorización de dispensación de medicamentos y productos sanitarios de uso humano por parte de los enfermeros. Disponible a: https://www.boe.es/boe/ dias/2015/12/23/pdfs/BOE-A-2015-14028.pdf [Consulta 02-01-2017] 
311 Kleinpell R, Gawlinski A. Assessing outcomes in advanced practice nursing practice: the use of quality indicators and evidence-based practice. AACN Clin Issues. 2005;16:43-57.

312 Dias $\mathrm{MH}$, Chambers J, Reidy $\mathrm{M}$. The consultation component of the clinical nurse specialist role. CJNR. 2010; 42(2): 92-104. Disponible a: http://cjnr.archive.mcgill.ca/article/ viewFile/2254/2248 [Consulta 20-02-2017]

313 Almero-Canet A, López-Ferrer M, Sales-Orts L. La colaboración interinstitucional en la producción científica española en enfermería: análisis de redes sociales. Enferm Clin. 2013; 23(3): 118-27.

314 Orellana A, Sanhueza O. Competéncia en investigación en enfermería. Ciencia Enferm. 2011; 7(2): 9-17 . Disponible a: http://dx.doi.org/10.4067/S0717-95532011000200002 [Consulta 06-02-2017]

315 Gosden C, James J, Winocour P, Turner B, Walton C, Nagi D, et al. Leading the way: the changing role of the diabetes specialist nurse. J Diabetes Nurs. 2009; 13(9): 330-7.

316 Generalitat de Catalunya. Departament de Salut. Pla de Salut de Catalunya 2016-2020 Disponible a: http://salutweb.gencat.cat/web/.content/home/el_departament/Pla_salut/pla_salut_2016_2020/Documents/Pla_salut_Catalunya_2016_2020.pdf [Consulta: 02-02-2017]

317 Kousoulis AA, Patelarou E, Shea S, Foss C, Ruud Knutsen IA, Todorova E, et al. Diabetes self-management arrangements in Europe: a realist review to facilitate a project implemented in six countries. BMC Health Serv Res. 2014;14:453.

318 Del Rio Moro O, Perezagua García MG, Villalta Sevilla MT, Sánchez Donaire A. Satisfacción del personal de enfermería ¿se cumplen nuestras expectativas?. Enfermería Cardiovascular/ Cardiovascular Nursing. 4to. Congreso Virtual de Cardiología. Disponible a: http://www.fac.org.ar/ccvc/llave/tl014/tl014.pdf [Consulta 05-02-2017]

319 Ponce-Gómez J, Reyes Morales H, Ponce Gómez G. Satisfacción laboral y calidad de atención de enfermería en una unidad médica de alta de alta especialidad. Rev Enferm IMSS. 2006; 14 (2): 65-73. Disponible a: http://www.medigraphic.com/pdfs/enfermeriaimss/ eim-2006/eim062b.pdf [Consulta 05-02-2017]

320 Crespo A, Cosme MA. Satisfacción laboral de los profesionales enfermeros de Talavera de la Reina. Metas Enferm. 2012; 15(10):63-8.

321 Carrillo-García C, Ríos-Rísquez M I, Fernández Cánovas, M L , Celdrán-Gil F, Vivo-Molina MC, Martínez-Roche ME. La satisfacción de la vida laboral de los enfermeros de las unidades móviles de emergencias de la Región de Murcia. Enferm Global. 2015; 40: 266-75. 
322 Pablos González MM, Cubo-Delgado S. Satisfacción laboral de las enfermeras de los hospitales públicos de Badajoz. Med Segur Trab. 2015;61(239):195-206. Disponible a: http:// scielo.isciii.es/pdf/mesetra/v61n239/06_original4.pdf [Consulta 06-02-2016]

323 Campbell SM, Fowles ER, Weber BJ. Organizational structure and job satisfaction in public health nursing. Public Health Nurs. 2004; 21(6): 564-71.

324 Arriaga E, de la Torre J, Alberdi RM, Artigas B, Moreno J, García JM. La participación en la gestión como elemento de satisfacción de los profesionales: un análisis de la experiencia andaluza. Enferm Global. 2003; 3: 1-13.

325 López F, Bernal L, Cánovas A. Satisfacción laboral de los profesionales de un hospital comarcal de Murcia. Rev Calid Asist. 2001;16:243-6.

326 Herrera G, Manrique FG. Condiciones laborales y grado de satisfacción de profesionales de Enfermería. Aquichan. 2008; 8(2):243-56.

327 López MP, Torrejón G, Martín A, Martín J, Pleite F, Torres MA. Estrés y satisfacción laboral de las enfermeras de hospitales toledanos. Metas Enferm. 2011;14(8):8-14.

328 Carrillo-García C, Solano-Ruiz MC, Martínez Roche ME, Gómez-García Cl. Influencia del género y edad: satisfacción laboral de profesionales sanitarios. Rev Latino Am Emfermagem. 2013; 21(6):1314-20.

329 Ruzafa M, Madrigal M, Velandrino A, López L. Satisfacción laboral de los profesionales de enfermería españoles que trabajan en hospitales ingleses. Gac Sanit. 2008;22(5):434-42.

330 García A, Moro MN, Medina M. Evaluación y dimensiones que definen el clima y la satisfacción laboral en el personal de enfermería. Rev Calid Asist. 2010;25(4):207-14.

331 Tapia H, Ramírez C, Islas E. Satisfacción laboral en enfermeras del hospital de oncologia Centro Médico Nacional Siglo XXI IMSS. Rev Enferm Universit ENEOUNAM. 2009;6:21-5.

332 Núñez Gonzalez E, Estevez Guerra GJ, Hernández Marrero P, Marrero Medina CD. Una propuesta destinada a complementar el cuestionario Font-Roja de satisfacción laboral. Gac Sanit. 2007;21(2):136-41.

333 Del Barrio-Linares M. Competencias y perfil profesional de la enfermera de práctica avanzada. Enferm Intensiva. 2014;25(2):52-7. 
244

$$
44
$$




\section{1. ÍNDEX D’ANNEXOS}

Annex 1: Guió per a l'entrevista semiestructurada als professionals

Annex 2: Qüestionari de l'estudi: Situació actual de l'educació terapèutica en diabetis a Catalunya

Annex 3: Document d'informació relativa a l'estudi per a les direccions dels hospitals

Annex 4: Document d’aprovació del Comitè Ètic d'Investigació Clínica

Annex 5: Document d'informació relativa a l'estudi per a les direccions de les Arees Bàsiques de Salut

Annex 6: Carta de suport de l'Associació Catalana de Diabetis per a la realització de l'estudi

Annex 7: Informació al diari La Vanguardia relativa al curset informatiu per a persones amb diabetis organitzat per La Lucha Antidiabética i l'Hospital de la Cruz Roja

Annex 8: Ponència del grup de treball d'educació sanitària a les «Jornades sobre programes comunitaris en diabetis»

Annex 9: Resum de la comunicació «Formación de profesionales socio-sanitarios en educación sanitaria (ES). Propuesta piloto de formación en ES en el área de la Diabetes. Catalunya 19851987", presentada pel Consell Assessor sobre la Diabetis a Catalunya a la I Conferencia Europea de Educación Sanitaria para la Salud UIES

Annex 10: Resum de la comunicació "Estrategia para el inicio de un programa educativo», presentada a la IV Jornada Anual de I'Associació Catalana d'Educadors en Diabetis

Annex 11: Primers Estatuts de l'Associació Catalana d'Educadors en Diabetis

Annex 12: Resum de la comunicació «Proposta d'unificació de criteris en educació dietètica a pacients diabètics», presentada a la II Reunió Anual de l'Associació Catalana d'Educadors en Diabetis i recollida en la 2a Circular informativa a l'octubre de 1986

Annex 13: Invitació del Consell Assessor sobre la Diabetis a Catalunya i l'Associació Catalana d’Educadors en Diabetis en una conferència extraordinària sobre «Formació de Professionals», amb la participació del professor Maurizio Mori 
Annex 14: Resum de la comunicació «La persuasió: un problema d'ètica», feta per Mme. Anne Lacroix el febrer del 1991

Annex 15: Normes per a la presentació de treballs per aspirar al I Premi de l'Associació Catalana d'Educadors en Diabetis

Annex 16: Aval de l'Associació Catalana d'Educadors en Diabetis i el Consell Assessor sobre la Diabetis a Catalunya al treball «Passat, present i futur de l'educació diabetològica al sector de Terrassa» Es mostra també el document complet del treball

Annex 17: Resum de la comunicació «Educació sanitària aplicada a la diabetis. Opinió dels professionals», presentada al I Congrés de l'Associació Catalana de Diabetis

Annex 18: Informe sobre l'enquesta d'educació diabetològica a Catalunya i programa de l'acte organitzat a l'Acadèmia de Ciències Mèdiques de Catalunya i Balears on es van presentar els resultats 


\section{ANNEX 1}

GUIÓ PER A LA ENTREVISTA ALS PROFESSIONALS IMPLICATS EN LA INTRODUCCIÓ DE LA EDUCACIÓ TERAPÈUTICA EN DIABETIS A CATALUNYA

Catalunya va ser pionera en la introducció de l'Educació Terapèutica (ET) dels pacients amb diabetis. M'interessa conèixer l'evolució que ha tingut l'ET al llarg dels anys per part de les persones implicades en aquest procés

M’agradaria conèixer la seva experiència respecta al procés del l'Educació Terapèutica en diabetis des de que va començar fins ara

- Quines creu que van ser les motivacions inicials per introduir l'educació dels pacients amb diabetis en la rutina habitual?

- Com creu que es va viure aquest canvi dins dels equips professionals?

- Quin tipus de suport institucional o de l'administració rebien?

- En la seva experiència quines van ser les majors dificultats per la implementació de l'educació terapèutica en diabetis?

- Creu que es disposaven dels recursos suficients?. Quines eren les mancances?

- Quina formació en educació de pacients tenien els professionals que van apostar per aquest canvi en el tractament de les persones amb diabetis?

- Quin col-lectiu de professionals va liderar inicialment l'educació en diabetis dels pacients i perquè?

- Creu que es va aconseguir assentar unes bases solides perquè l'educació terapèutica hagi estat reconeguda i valorada com una necessitat i un dret del pacient amb diabetis?

- Perquè creu que ha estat així?

- Com valora el grau d'implantació de l'educació terapèutica en el moment actual?

- Què opina sobre la formació en diabetis i educació que actualment tenen els professionals? 


\section{ANNEX 2}

\section{ESTUDIO SOBRE HISTORIA Y SITUACIÓN ACTUAL EN CATALUNYA DE LA EDUCACIÓN TERAPÉUTICA EN DIABETES Y ROL DE LA ENFERMERIA}

\section{Información del estudio}

Este estudio forma parte de una tesis doctoral y tiene como objetivo conocer la situación actual de la Educación Terapéutica en la Diabetes en Cataluña. La encuesta va dirigida a enfermeras/os dedicadas al cuidado de pacientes con diabetes tanto de la Asistencia Primaria como de la Asistencia Especializada

Le pedimos que conteste todas las preguntas de esta encuesta. Su participación es importante y sus respuestas serán anónimas, confidenciales y solamente serán descritas en conjunto.

Al participar en esta encuesta Usted nos proporciona su consentimiento para incluir sus respuestas en una base de datos que se analizará posteriormente (en ningún caso serán identificables).

Este proyecto:

- Ha sido valorado y aprobado por el Comité Ético de Investigación Clínica (CEIC) del Hospital Universitario Mútua Terrassa.

- Tiene el soporte de l'Associació Catalana de Diabetis (ADC). Ver documento adjunto

Usted necesita aproximadamente 15 minutos para contestar la encuesta.

\section{Le agradecemos de antemano el tiempo dedicado}


A la atenció de:

Direcció d'Infermeria

ANNEX 3

Hospital

Terrassa

de 2014

Benvolgut/da company/a

El meu nom es Maite Valverde. Treballo com infermera educadora de diabetis al Hospital Mútua Terrassa a Terrassa (Barcelona). Estic realitzant un estudi per la tesi doctoral "La historia i situació actual de l'educació terapèutica en diabetis a Catalunya i el rol del professional de la infermeria".

Donat que els pacients amb diabetis son atesos i reben educació tant a l'àmbit de l'atenció especialitzada com de l'atenció primària, aquest estudi inclou ambdós àmbits.

L'àmbit de l'atenció especialitzada inclou els Hospitals on hi ha Unitats d'Endocrinologia i Nutrició però també aquells que, encara que no disposin d'aquesta unitat, els pacients amb diabetis que s'atenen reben educació per part d'algun professional infermer/a, amb dedicació a temps complert o parcial.

Com a directora del centre, li agrairia, si es possible, em faciliti el posar-me en contacte amb la persona/es responsable/s de l'educació dels pacients amb diabetis perquè em responguin a una enquesta (arxiu adjunt). En cas de que l'hospital no disposi d'aquest servei li agrairia també que m’ho notifiqués.

L'objectiu d'aquesta enquesta es conèixer la situació actual de l'educació terapèutica en diabetis a Catalunya i el rol del professional de la infermeria en aquestes unitats.

L'enquesta està en format "word", que es pot descarregar, contestar i enviar en aquesta mateixa adreça: maite.valverde@gmail.com

L'estudi:

- Ha rebut el suport de l'Associació Catalana de Diabetis (ADC) (adjunto document)

- Ha estat aprovat pel Comitè Ètic d'Investigació Clínica de l'Hospital Universitari Mútua Terrassa (adjunto document)

Agreixo per endavant la seva col·laboració, sinó no serà possible fer aquest estudi

Atentament

Maite Valverde Torreguitart

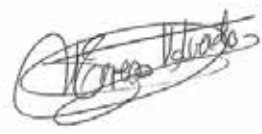

Infermera educadora de diabetis

Servei d'Endocrinologia i Nutrició 


\section{ANNEX 4}

\section{MútuaTerrassa}

\section{COMITÉ ÉTICO DE INVESTIGACIÓN CLÍNICA}

Dr.Ramón Pla Poblador, como Presidente del Comité Ético de Investigación Clínica del Hospital Universitari Mútua Terrassa

\section{CERTIFICO:}

Que ha sido sometido a este Comité en su reunión del día 30 de julio de 2014 (Acta 07/14) para su aceptación, el Proyecto de investigación titulado "Història i situació actual de l'Educació Terapèutica en Diabetis a Catalunya"

Que una vez evaluado dicho estudio, así como la capacidad del equipo investigador y medios disponibles del Centro, este Comité considera adecuado el estudio y su realización por la Sra. Maite Valverde Torreguitart.

Terrassa a 30 de juliol de 2014.

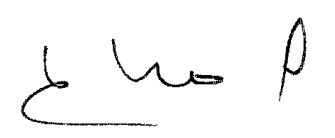

Dr. Ramon Pla

Presidente del CEIC 


\section{ANNEX 5}

A la Atenció de:

Terrassa de de 2015

Apreciada companya

El meu nom es Maite Valverde. Treballo com infermera educadora de diabetis al Hospital Mútua Terrassa, de Terrassa (Barcelona). Estic realitzant un estudi per la tesi doctoral sobre " La historia i situació actual de l'educació terapèutica en diabetis a Catalunya i el rol del professional de la infermeria".

Donat que els pacients amb diabetis son atesos i reben educació tant a l'àmbit de l'atenció especialitzada com de l'atenció primària, aquest estudi inclou ambdós àmbits.

S'han extret de forma aleatòria 140 àrees bàsiques de salut (ABS) de les 364 existents a Catalunya i una de les escollides es l'ABS

Agrairia la seva col-laboració perquè com a mínim, tres infermeres del centre responguin l'enquesta que li adjunto. Han de ser infermeres de la plantilla habitual que atenguin a persones amb diabetis.

La enquesta està en format "word", que es pot descarregar, contestar i enviar en aquesta mateixa adreça: maite.valverde@gmail.com

L'estudi:

- Ha rebut el suport de l'Associació Catalana de Diabetis (ADC) (adjunto comprovant)

- Ha estat aprovat pel Comitè Ètic d'Investigació Clínica de l'Hospital Universitari Mútua Terrassa (adjunto comprovant)

Agreixo per endavant la seva col·laboració, sinó no serà possible fer aquest estudi

Atentament

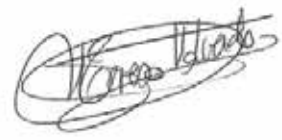

Maite Valverde

Infermera educadora de diabetis

Servei d'Endocrinologia i Nutrició

Hospital Universitari Mútua Terrassa 


\section{ANNEX 6}

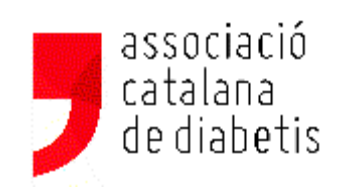

Des de l'Associació Catalana de Diabetis volem donar suport a la realització de la tesi doctoral titulada "La història i la situació actual de I'Educació Terapèutica en diabetis a Catalunya" per part de la Sra. Maite Valverde. Aquest projecte pretén analitzar quina és la situació actual de l'educació terapèutica a Catalunya i creiem que les conclusions que s'en derivin podrien ser d'interès per tots els professionals que es dediquen a la diabetis. Per aquest motiu, preguem la màxima col.laboració possible per part de les infermeres, tant d'atenció primària com especialitzada, amb les quals es contacta per respondre el qüestionari necessari per dur a terme l'estudi de la Sra. Maite Valverde.

Barcelona 2 de juliol de 2014,

Cordialment,

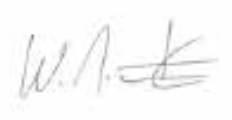

W. Ricart

I.Miñambres

President

Secretària 
Aunque por deseo de la familia no se hizo público el fallecimiento de la seffora Jacinta Martín. se tuvo conocimiento del fatal desenlace y ya a última hora de la tarde de ayer fueron muchos los testimonios de pé. same que hicleron patente la es. tima y consideración de que gozaba la finada.

El acto del entlerro está previsto pare las 4,30 de la tardie de hoy, en Vilassar de Mar, residencla habitual de la señora Martín. En fa parrocuial iglesia de Sant Joan de dicha localidad se oficlarán las honras fúnebres.

Expresamos a los familiares de la difunta $y$ muy especial. mente a su hijo, Ernest Lluch, nuestro pesar por la pérdida que han sufrido.
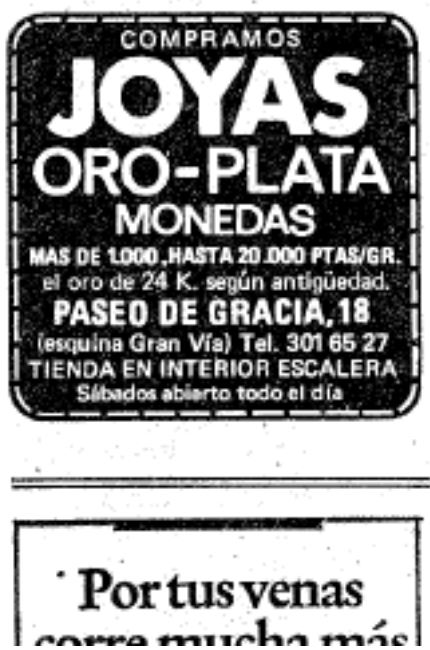

Turismo de la Generglitat, Fran. cesc Sanuy, ha sido intervenido en una clínica barcelonesa de una fístula, intervención de la que se recupere satisfactoriamente, han informado fuentes de la familia.

El sef̂or Sanuy, que viajo a Oslo y Viena los primeros dias de esta semana, se encontró mal a su regreso y no pudo asistic a la sesión del último consejo ejecutivo de la Generalitat. Ayer tarde tuvo que ser ingresado de urgencia $e$ intervenido. Se espera que, salvo complicaciones improbables, el seffor Sanuy po. drá ser dado de alta en breve.

\section{盟 Cursillo informativo para diabéticos}

La Lucha Antidiabética y el Serviclo de Endocrinologie, Nutrición y Dietética del Hospital de la Cruz Roja, organizan un cursillo informativo para diabé. ticos, especialmente a los tratados con insulina. Tendrá ocho sesiones, los lunes y jueves. desde el 28 de febrero at 21 de marzo, y terminará el dia 8 guiente. Participan los doctores César Pérez Vitoria, José López Batllori, Jaime Viguera Montesinos y Luis Vila Ballester. Las charlas, en el Hospital, Dos de Mayo, 301, a las slete y media de la tarde.

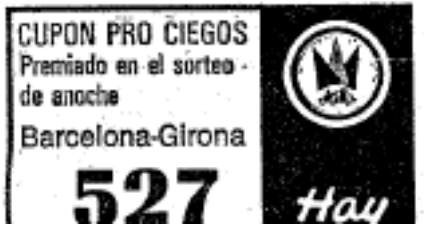




\section{ANNEX 8}

JORNADES SOBRE PROGRAMES COMUNITARIS EN DIABETIS

GRUP DE TREBALL: EDUCACIO SANITARIA

PONENCIA DEL GRUP DE TREBALL

AUTORS:

Mercè Bergua Llop

CAP Prat de la Riba- Lleida

Daniel Figuerola Pino

Clínica Tres Torres- Barcelona

Pilar Isla Pera

Hospital Clínic- Barcelona

Isabel Martinez Martínez

Judit Rodergas Pagés

CAP Prat de la Riba- Lleida

Hospital de Sant Jaume i Santa

Magdalena- Mataró

Justa Ubeda Abersuk

Hospital de la Sta. Creu i Sant PauBarcelona

Maria Vila Borrell

Hospital General de GranollersGranollers 


\section{PRESENTACIO}

\section{EDUCACIO SANITARIA APLICADA A LA DIABETIS}

La presentació que, a titol de ponència, se m'ha encarregat avui, és el resultat del treball d'un grup de professionals que, des dels hospitals universitaris, els hospitals comarcals, les unitats especialitzades i l'assistència primària, desenvolupen la tasca d'atenció al pacient diabètic, entenent el terme "atenció" com la combinació indivisible de: assistència + educació.

A l'hora de parlar de l'educació sanitària aplicada a la diabetis, començarem donant un cop d'ull a la història i veiem que, pel que fa a l'esperança i la qualitat de vida dels diabètics, és en aquest segle, el segle $\mathrm{XX}$, que hi ha canvis $i$ millores importantíssimes.

La insulina arriba a Catalunya l'any 1923 de mans del Dr. Rossend Carrasco i Formiguera.

Els instruments terapèutics continuen sent dieta - fàrmacs (hipoglucemiants oral-insulina) - exercici, amb resultats poc exitosos: és una època de baixa satisfacció professional.

Arriba la dècada dels 80 amb una novetat: l'educació sanitària aplicada a la diabetis, que resulta ser un nou instrumen terapèutic.

Pel que fa a Catalunya hi ha unes dates molt significatives que cal recordar:

1982. Hospital Clinic de Barcelona Curs del Prof. G. Ruffino

1983. Hospital de la Santa Creu i Sant Pau visita del Prof. Berquer

18.3.1983. Consell Assessor sobre la Diabetis a Catalunya 14.6.1984. Societat Catalana d'Educadors en Diabetis.

Veiem doncs que és en aquests últims anys que l'educació sanitària entra de ple en les unitats d'assistència al diabètic: comença als hospitals $i$ a poc a poc també en l'assistència primària i aquest fet significa per als professionals passar "del palelític a l'edat moderna" i per als diabètics, sobretot per als juvenils, que l'esperança de vida passa de 5 anys, tirant llarg, amb un agressiu deteriorament, a 80 anys comparables als d'una persona no diabètica. Canvi radical en el PRONOSTIC La comercialització general de sèrums $i$ antibiòtics, en permetre el tractament eficac de les complicacions intercurrents, permet parlar amb optimisme. de les espectatives de vida, d'aguesta vida gue gràcies a la insulina pot ser més llarga. 
Des dels anys 50 fins a lá segona meitat de la dècada dels 70 , és una llarga època grisa. Mentre altres especialitats es beneficien dels nous descobriments $i$ els avencos de la biotecnologia, no hi ha durant aguest temps res de nou en relació amb la diabetis.

Curiosament, la inguietud per l'educació diabetològica neix en els hospitals d'alta especialització. Hi ha una progressiva sensibilització pel tema dels professionals amb una formació biomèdica alta, i molt baixa o nul.la en pedagogia i didàctica. D’aquí neix un nou problema: com ensenyar?

Si tenim en compte gue tendim a reproduir la forma en guè hem estat ensenyats, és natural que la pregunta "com ensenyar?" provogui un seriós neguit en els professionals que creuen fermament en l'educació sanitària com un instrument més del tractament.

Cal afegir també gue incorporar l'educació de forma paral.lela i simultània a l'assistència implica, sens dubte, un canvi en l'estil professional.

Nosaltres no tenim pas una resposta a aguesta pregunta, ni creiem que n'hi hagi una de sola, de resposta, gue sigui la veritable. Es per això que creiem que el que pot ser més enriguidor per a tots és ser fidels a la justificació d'aquestes jornades. Tal com està indicat a la contraportada del programa, "Aguestes jornades pretenen oferir un marc de debat $i$ discussió als professionals dels diferents nivells assistencials (atenció primària $i$ especialitzada) en l'organització i la implementació de programes comunitaris en diabetis al nostre medi".

Nosaltres no hem volgut analitzar aquests escassos deu anys de vida de l'educació diabetològica al nostre país, volem que aquesta ponència sigui el resultat $d$ 'un ampli debat obert, en comptes de les conclusions d'un grup d'experts.

Tot i aixi partirem de dues dades gue hem recollit com a material de partida per al debat. Per comencar tenim el resultat del test d'opinió que s'ha passat a tots els participants. I en segon lloc, tenim una filmació en vídeo que si be pot semblar un xic caricaturesca estem segurs gue molts de nosaltres ens hi podem sentir identificats en algun moment.

En el debat s accepten totes les opinions i punts de vista. totes les crítigues si són serioses i rigoroses. Hauriem de ser capacos entre tots d'analitzar quins són els errors més habituals, fugir de les anècdotes $i$ també de les queixes i/o lamentacions $\mathrm{si}_{\mathbf{I}}$ no a.juden a construir un suggeriment alternatiu.

Després del temps del debat esperem poder recollir sintèticament quins són el sentiment i l'opinió del grup al voltant d'aquestes tres preguntes:

- Què es pretén amb l'educació diabetològica?

- Com es realitza?

- Com és rebuda pel diabètic? 
EDUCACIO SANITARIA APLICADA A LA DIABETIS

1. Cal que el personal sanitari tingui una ACTITUD favorable i convençuda

2. Tan sols entenem l'educació diabetològica estretament lligada al tractament i seguiment

3. Es fa necessària una formació específica

4. No hi ha models reproduïbles, però sí que hi ha mètode de treball (que cal disciplina i professionalitat)

5. L'educació deixada al voluntarisme i l'espontaneïtat pot ser iatrogènica. 


\section{ANNEX 9}

FORMACIÓN DE PROFESIONALES SOCIO-SANITARIOS EN EDUCACIÓN SANITARIA(E S $)^{2}$. Propuesta Piloto de Formación en E.S. en el área de la Diabetes. Catalunya 1985-1987.

CONSELL ASSESSOR SOBRE LA DIABETIS 1983-1990.

Generalitat de Catalunya

Departament de Sanitat

i Seguretat Social

DE JUAN-CREIX I*, MARTINEZ $\mathrm{M}^{* *}$, GASTELL $\mathrm{C}^{*}$, BOFILL $\mathrm{G}^{*}$, PRATS $R^{*}$, MARTINEZ JM*, RUFINO G***, MORI M****, FERRARI $A * * *$, LLOVERAS $G *$.

* Departamento de Sanidad y Seguridad Social.

Generalitat de Catalunya.

**Area de Sanidad. Ayuntamiento de Santa Coloma de Gramanet.

***WHO Collaborating Center for Diabetes,

University Cantonal Hospital. Geneve.

***Centro Sperimentale Educazione Sanitaria.

Università di Perugia. Italia.

Comunicación presentada a la I Conferencia Europea de Educación Sanitaria par

la Salud UIES.

Madrid 25 - 28 de Marzo de 1987.

Correspondencia: Consell Assessor sobre la Diabetis a Catalunya.

Departament de Sanitat i Seguretat Social

Travessera de les Corts 131-159, 08028 BARCELONA

Tel. 93/ 330.80.11./339.11.11 Telex 54205. 
PROGRAMME FOR TRAINING SOCIO-HEALTH PROFESSIONALS IN HEALTH EDUCATION: THE METHODOLOGY OF HEALTH EDUCATION IN DIABETOLOGY. Catalonia 1985/6

The various experiences in diabetes and health education in Catalonia over the last decade, which have been run with the cooperation of European institutions, have led official bodies to plan a Training Programme for Professionals in Diabetic Education.

The training course for teachers of diabetes education organized by the Department of Health and Social Security of the Generalitat (autonomous government) of Catalonia is presented here. This programme received methodological advice and teaching participation from the WHO Collaborating Centre for Diabetes, Geneva, and the Centro Sperimentale per 1'Educazione Sanitaria, University of Perugia, WHO Pilot Centre, IUHE. It was based on the needs of the professionals themselves, including doctors, nurses and dietitians, as well as on the teaching experience in diabetic education of the Swiss centre and the methodological experience in health education of the Italian centre.

The course represents a structured planning proposal for a programme of diabetes education within diabetic care, whose aim is to create a framework of analysis and conceptual and methodological reflection for the professionals who coordinate and plan diabetic education in Catalonia. The secondary objective is to set up different projects in diabetic education for the improvement of the care of the diabetic.

The training methodology is based on the daily work experience of the professionals and their reflection and development of critical analysis on this. The training involves observation of experiences, bibliographical investigation, group work, theoretical synthesis, advice, planning and participation as teachers on a course of further education for diabetic teachers and a real project in diabetic health education in the participant's own workplace.

Short term evaluation will be made of both the organizing process and the pedagogic and methodological content. In the medium term (1987) an analysis of the activities developed by participants will be made and in the long term (1988) the changes made in services themselves and in the attention received by patients will be studied.

On the basis of this experience we hope to develop a global, structured programe of diabetes education in Catalonia, and to draw on this project for other nosologies and action changes. 


\section{ANNEX 10}

\section{JORNADA ANUAL}

DE

L'ASSOCIACIÓ CATALANA

D'EDUCADORS EN DIABETIS

ASSOC. CATALANA D'EDUCADORS EN DIABETIS

SECCIÓ DE DIABETIS - HOSPITAL CLINIC Correr Cosonova, 143

08036 BARCELONA

\section{DEDCADORSEN DIABETIS}

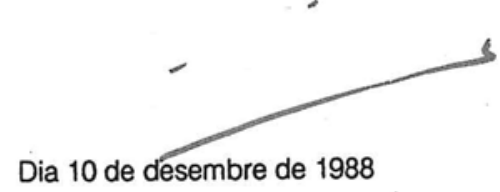

Lloc:

OBRA CULTURAL DE LA CAIXA D'ESTALVIS DE SABADELL

Carrer d'En Font, 1 - Sabadell 


\section{ESTRATEGIA PARA EL INICIO DE UN PROGRAMA EDUCATIVO}

Masoliver J.R., Surroca M.,Carrasco R.,Puig M., Guasch V. SERVICIO DE ENDOCRINOLOGIA

Hospital del Sagrado Corazón ( Q.S.A.) Barcelona.

OBJETIVO

Valorar la eficacia de un programa de Educación con respecto a la introducción del AUTOANALISIS en sangre capilar.

METODO

40 pacientes diabéticos ID, que no realizaban anteriormente autoanálisis, fueron introducidos en un Programa de Educación. Constaba de cinco clases directivas, participativas, en grupo de 5 a 6 personas, de una hora de duración cada una de ellas.Se realizaba una clase a la semana a lo largo de cinco semanas consecutivas. El temario constaba de los siguientes puntos: concepto de diabetes, Insulina, Hiper-Hipoglicemia, dieta y ejercicio, instrucción práctica en el autoanálisis. Al final se les entregó el Carnet de Diabético del C.A.D.C. instruyéndoles para que realizaran una dterminación diaria (en diagonal). Se les solicitó el carnet en las visitas clínicas posteriores. Alos 3 y 6 meses de finalizado el Curso, se envió a todos los pacientes una carta por Correo, solicitándoles que nos remitieran por escrito un perfil gljicémico de un solo día (6 puntos). No se adjuntó sobre ni sello, lo cual hubiera facilitado la respuesta.

\section{RESULTADOS}

El $70 \%$ de los sujetos estudiados siguen realizando autoanálisis en las visitas clínicas posteriores. El 32,5\% de los sujetos contestan a la carta enviada a los 3 meses, y de éstos, el 77\%, continúan contestando la carta a los 6 meses.

\section{CONCLUSIONES}

El programa Educativo consigue de forma eficaz que los pacientes se inicien en el autoanálisis, y los motiva suficientemente para mantener el control durante un tiempo prolongado. 


\section{ANNEX 11}

\section{"ESTATUTS DE L'ASSOCIACIO CATALANA D'EDUCADURS EN D́IABETIS"}

I. Es crea I'"ASSOCIACIO CATALANA D’EOUCAOCRS EN DIABETIS"(A.C.E.O.). A.i.

2. RAO D'ESSER. Es considera l'Educació Diabetològica com a part fona mental de la tasca de prevenció i tractament de la Diabetis Mellitus. En aquest sentit, l'Educacio Diabetologica s'inscriu dintre del concepte d’Educació Sanitaria com a instrument ineludible de promoció de la Salut.

3. DOMICILI I AMBIT TERRITORIAL. La seu social queda fixada a Barcelo na. Secci6 de Giabetis. Hospital Clínic. Carrer Casanovas 143 08036 Barcelona. L'àmbit de l'acció de L'A.C.E.D. serà el territoIí geogràfic corresponent a la Comunitat Autonòmica de Catalunya.

4. GBIECTIUS. L'A.C.E.D. es proposa:

a) Millorar la qualitat de vida del diabètic, ajudant-li a ser el més independent possible respecte la seva afecció, facilitantli l'adscripcí́ a les normes terapèutiques.

b) Desenvolupar programes educacionals que informin al diabètic en relació a la seva malaltia i a la necesitat de responsabilitzarsi activament del control de la mateixa.

c) Estudiar i posar en marxa metodologies que facilitin al diabètic la seva específica formacib i aprenantatge.

d) Avaluar i acreditar els diferents metodes i sistemes educacionals tant els individuals com els de grups: Xerrades, cursos, publicacions, audiovisuals, colonies, etc.

e) Promoure cursos especialitzats par a Educadors en Diabetis i me canismes d’educació continuada, facilitant a la Sanitat fública i exigint-li a la vegada uns mecanismes de progressiva acredita ció, titulació i profesionalització óaquesta tasca, dedicant a la mateixa els recursos econòmics necessaris. 
f). Incidir en que l'educació diabetològica s'implanti en els diferents nivels o'atenció al diabetic.

9) Fomentar la investigació específica en Educació Diabetológica

h) Informar a la població en general dels rics individuals i col-. lectius de la Diabetis $i$ de les avantatges d'una tasca de profi laxi. Dintre d'aquest objectiu es posa un especial èmfasi en l'́ educació alimentåria de la població.

i). Mostrar que la inversió en l'Educació Diabetològica suposa una reduccio del cost social de la diabetis.

La Direcció i responsabilitat d'aquestes finalitats recaura 'soles persones titulades al efect.

5. MEMBRES. L'A.C.E.D. neix com a resultat de la voluntat d'un grup de metges, personal d'infermeria i dietistes, que han estat treballant en aquest tema en diverses institucions. Els membres de l'h.C.E.D. hauràn d’èsser reclutats dels grups de metges, personal d'infermeria i dietistes i tanmateix, qualsevol persona que pugui acreditar una tasca seriosa, eficaç, respansable i basada en realitzacions ob jectives d'instrucció al diabetic( pedagogs, assistents socials, psicolegs, etc.). podran ser membres d’aquesta Associació. La Junta Directiva haurà de donar el vist-i-plau a qualsevol peticióo d'ingrés.

Suposat el respecte a qualsevol opció filosỏfica o política, els membres de l'A.C.E.D. fan explícita, mitjançant l'acceptació d’aquests Estatuts, la intenció de no instrumentar l'Associací en be nefici de cap d’aquestes opcions.

L'A.C.E.D. col.laborarà amb les associacions de diabettics amb un dels objectius comuns que es l'Educació Diabetológica.

DRETS I DEURES DELS SOCIS. Son drets de tots els socis:

a) Prendre part en les Assableas Generals de l'Associació i en les 
seves deliberacions, amb veu i vot.

b) Eligir i esser elegits com a membre de la Junta Directiva.

c) Exposar per escrit a la Junta Directiva quixes i sugerencies respecte de I'Associací $i$ de les seves activitats.

d). Sol.licitar infornació sobre la marxa de l'Associació.

Son deures de tots els socis:

a) Cumflir les obligacions quels Estatuts senyalin i els acords adoptats per l'Associacio, a traves dels seus orgàns de Govern.

b) Abonar les quotes que fixi l'Assamblea General.

c) Asistir a les Assambleas Generals i col.laborar al millor desenvolupament de les finalitats de l'Associacio.

6. ORGANS DE GOVERN. Aquesta Associació tindrà la personalitat Jurídica i la capacitat d'otrar plenament.Es regirà per el sistema d'autogovern i principi de representació, a traves dels sigüents òrgans:

L'Assamblea General i la Junta Directiva.

6. I ASSAMELEA GENERAL. Es l'órgan suprem i Sovirà de l'Associació $i$ per tant amb plenituts de poders a prendre els acords pertinets. Serà constituida per la totalitat dels membres de l'Asso ciació.

L'Assamblea General celebrara sessió ordinaria cada curs. Es reunirà en sessi6 extraordinaria tantes vegades com l'acordi la Junta Directiva per la majoria de dues tersis, o per la sol. licitut de la tercera part dels socis, per escrit dirigit al President, degudament autoritzat per les signatures corresponents, $i$ en el que de manera raonada s'exposi el motiu de la convocatoria.

FUNCIONS DE L'ASSAMBLEA GENERAL. Les funcions de l'Assamblea General Ordinaria son:

a). Examinar $i$ aprovar la memoria anual de la Junta Directiva que compendrà una exppsicí6 de totes les gestions portades a ter 
me en els diferents òrgans $i$ autoritats $i$ dels resultats de les mateixes, aixi com de les activitats realitzades per 1 Associació.

b) Aprovació de les comptes corresponents al exercici anterior.

c). Fixar les quotes.

d): Aprovar, si procedeix, les reglaments de Règimen Interior de I'Associació que facilitin el desenvolupament de lo previs en els presents Estatuts, sin contravenir lo disposat $\in$ els mateixos.

e) Aprovació del presupost del ejercici del any en curs.

f). Nombrament i renovació dels càrrecs de la Junta Oirectiva. Els accords de l'Assamblea General obligan a tots els socis. Els càrecs de President i Secretari recauran sobra els mateixes socis qui occupin aquest càrrecs en la Junta Directiva. L'Assamblea General serà convocada per la Junta Directiva, i en el seu nom per el President, amb quince dies d'antelació com a minimin mitjonçant un escrit dirigit a cadascun del socis fent constar a traves del corresponent ordre del dia, els assumptes que hagin d’èsser sotmesos a la deliberacio de l'Assam blea General.

Les Assambleas Generales tant Ordinàries com Extraordinàries, quedaràn degudament constituides, en primera convocatoria, quand hi assisteixin la majoria dels socis, $i$ en segona convocatoria qualsevol que fos el número de socis assistents. Seran competencias de l'Assamblea General Extraordinaria:

a) Sol.licitar declaracio d’utilitat pública.

b) Sol.licitar la constitució de "federacions d'Associacions d'aquest tipus, o d'integrarase dintre de les mateixes si jè existissin.

c) Modificar els Estatuts i accordar la disalució de l'Associa cí́. 
6.2 JUNTA DIRECTIVA. Es l'òrgan rector i executiu de l'Associació. Serà integrada per:

- Fresident.

- Vicepresident.

- Tresorer.

- Vocal I.

- Vocel II.

- Vocal III.

- Vocal IV.

- Vocal V.

Tots els cèrrecs de la Junta Directiva tindrèn un caracter hó' norific i totalment gratuits.

Cada dos anys es renovarè la meitat de la Junta Directiva comenşant, després del primer mandat, per Vicepresident, Tresorer, Vocal II i Vocal IV.

Per a un mateix càrrec, un membre es reelegible només une vega da. L'elecció dels membres de la Junta Directiva es reaiitzarè mitjançant normes clarament democràtiques, a l'Assamblea General l'ardre del dia de la qual due contemplar aquest punt.

No podrèn coincidir en una meteixa Junta Directiva mes cie dos membres que partànyin a una mateixa institució a lloc habitual de treball, a fí d’assegurar l'adequada disfersació de representativitats, amb un criteri descentralitzador.

Aquests Estatuts defineixen aquesta agrupació com una Associació la finalitat de la qual es estimular i aprofitar el millor possi ble les institucions sanitèries dels governs autònomics i, alhora expressen la seva intenció d’agrupar l'A.C.E.D. en una "Federación Espeñola de fisociaciones de Educedores en Diabetes".

La Junta Directiva estarà abligada a cumplir els seus propis accords.i, els adoptats per l'Assamblea General de socis. Serà res ponsable devent 1 'Assamblea General dels actes relacionants amb el exercici de les seves foncions. 
FACULTATS OE LA JUNTA OIRECTIVA. Serèn faclitats de la Junta Directiva:

a) Representar col.legialment a l'Associació.

b) Convocar i fixar la dafa de celebració de l'Assamblea cheneral tant ordinàría com Extraordinària.

c) Drganitzar i desenvolupar les accions aprovades per la Junta Directiva.

d) Donar el vist-i-plau a les noves sol.licituts d'ingrés.

e) Cubrir les vacants qu'es puguin produir a la Junta Directiva fins la propera Assamblea General prevista per a la renovació de càrecs de l'esmentada Junta Directiva.

f) Confeccionar les memories, presuposts $i$ comptes anuals per a someterles a l'asamblea General.

s) Proposar a l'Assamblea General les comptes ordinàries i extraordinàries que siguin procedents. Regularitzar el Règimen econòmic de l'Asseciació, aixi com la seva organitzacio admi nistrativa, organitzar i diriguir els serveis i actes de l'A sociació.

h) Interpretar els Estatuts de l'Associació i vetllar per el cum pliment dels mateixos.

i) Realitzar cuantes foncions es considerin precises per a la bona marxa de l'Associació $i$ que no siguin assignades expressament a l'Assamblea General de la mateixa.

FUNCIONS DEL PRESIOENT. Les foncions del fresiderit serèn:

a). Dstentacio de la representativitats de l'Associació quand no puguin ésser col.legiada, devant les autoritats i organismes públics i privats.

b) Convocar l'Assamblea General i la Junta Directiva i presidir les seves reunions. 
c) Revisar les actes de les sessions, i vigilar que es comile xin els accords edoptats.

d) Respondre devant l'Assamblea de la gestió realitzada per la Junta Directiva.

FLNCIONS DEL VICE-FRESIDENT. Les funcions del Vice-president serèn les de sustituir al fresident en les seves ausencies i assumir la seva representativitat per delegació en la forma que acordi la Junta Directiva o el Fresident li indicui.

FUNCIONS DEL SĘCRETARI . El Secretari de l'Assamblea General tammateix ho serà de la Junta Directiva. En els dos casos for terà els llibres d’actes corresponents als òrgans respectius. Les actes hauràn també d'ésser signades per el fresident. Tindrà cura de la correspondencia i arxius de l'Assaciació i el. re gistre de socis.

Amb la col.laboració del Tresorer redactara la memoria i balanç del exercici expedint les corresponents certificacions de tot el que estigui a càrrec seu amb el viot-i-plau del fresident i I'aprovació de la Junta Directiva.

FURCIONS DEL TRESORER. El Tresorer custodiarà d'accord amb El President, els fons socials, efectuarà el cobrament de les quo tes, atendrà els pagaments autoritzats per el fresident i porterà els llibres de comptabilitat de conformltat amb les disposicions légals.

Redactarà d'acord amb la Junta Directiva, el balanç i pressuposts anuals que hauràn d'ésser sotmesas a aprovació a l'Assan blea General.

Col.laborara amb el Secretari en la redacció de la memoria anuel.

En el cas d'abertura de comptes bancaries serà imprescindible suscriure els oportuns documents mencomunadament, el Tresorer amb el President o Secretari $i$, si la Junta aixi ho estinés, 
amb un altre membre de le Junta Directiva.

Expedirà les certificacions pertinents de tot allo que cettigui al seu càrrec amb el vist-i-ple del fresident.

FUNCIONS OELS VOCALS. Els vocals a més de les seves funcions ordinaries, podràn rebra per acord de la Junta Directiva, el encàrrec de presidir, coordinar grups de treball, o de execu ció d'encèrrecs, comisions, representativitats $i$ altres tasques que per la Junta Directiva els fossin encomenats.

7. FINANCAMENT. L'A.C.E.O. es una agrupació sense cap firalitat lucrativa.

Inicialment l'Associací6 no té Patrimoni fundacional.Intentarà autofinançar-se mitjançant una quota anual que abonaràn els seus membres.

Perd forma part de les tasques de la Junta Directiva el trobar recursos econdmics que permetin mantenir les activitats al més alt nivell possiblc. Obviament aquests ajuts no condicionarèn ni el sentit ni el contingut d’aquestes activitats.

El presupots anual inicial tindrà con a limit maxin la quantitat de siscentes mil pessetes.

8. Dissolucio. L’A.C.E.D. es dissolverà només per l'acord de I'Assam blea General.

En cas de que s'arribés a una dissolucí, actuarà com a comissió liquidadora la última Junta Dircctiva en exercici, la qual destinarà els fons econòmics - si - n’hi hagues - a institucions diabetològigues de clar objectiu social.

9. REGLAMENT. fquests Estatuts funciomels de I'Associació Catalana d' Educadors en Diabetis, tindràn un desenvolupament més concret i detallats en un Reglament de Règiment Interior, que la primera 
Junta de Govern proposarà, per a la seva aprovació, a l'Assamblea General Sobirana.

BARCELONA. I2 de Novembre de mil noucents vuitanta quatre.

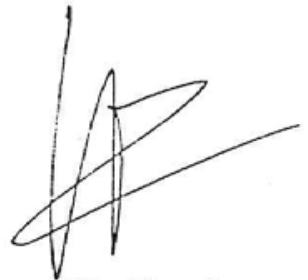

Josep Ma Pla Bartina

D.N.I. 40.144 .436

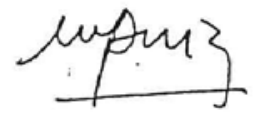

Manel Puig Domingo

D.N.I. 37.68I.596

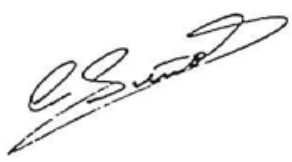

Carmen Suñol Gurnes

D.N.I. 36.904.0I6

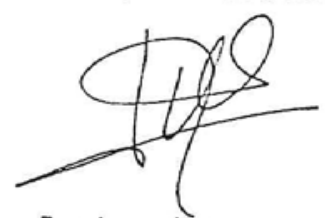

Justa Ubeda Arbesuk

D.N.I. 22.663 .235

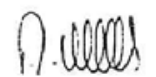

Daniel Figuerola Pino

D.N.I. 37.624 .234

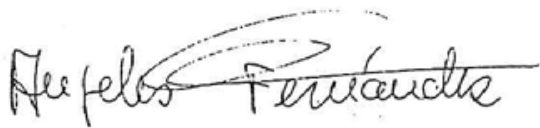

Angeles Fernández de Bustos

D.N.I. I2.685.0II

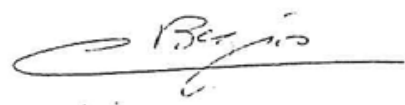

Colette Bezio Regis

D.N.I. 46.340 .949

\section{man Camen delas Heras}

Ma Carmen de las Heras Durán

D.N.I. 46.103.384

Diligència: Els Estatut's de l'Associació..... CATACANA D'EDUCADORS EN DIABETIS (A.C.E.D.)

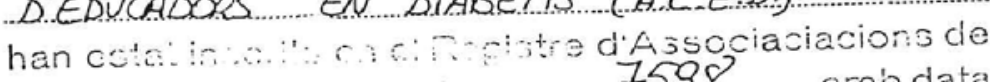
Earccios uny 6 igs

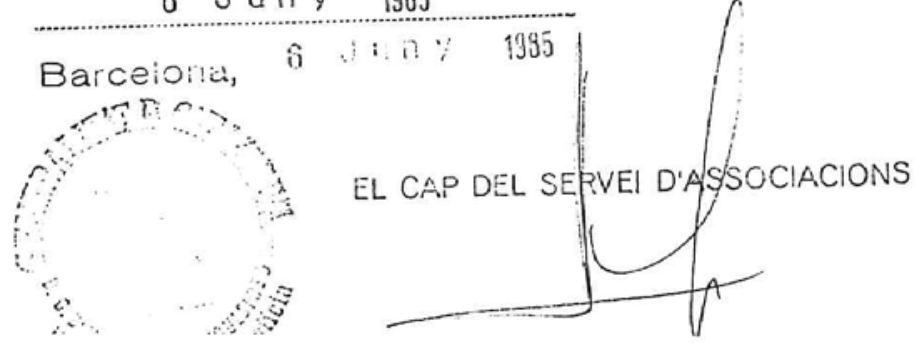




\section{ANNEX 12}
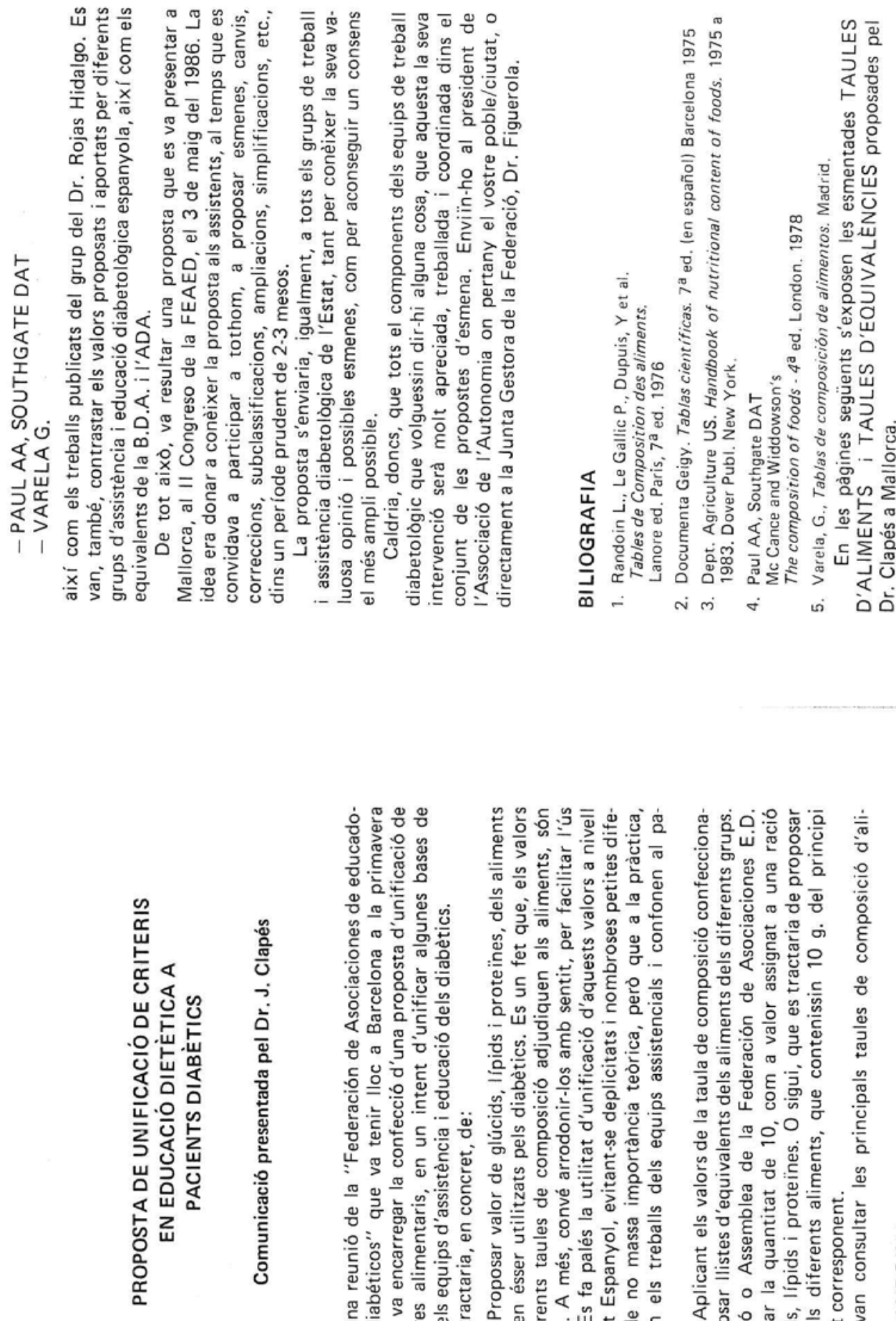

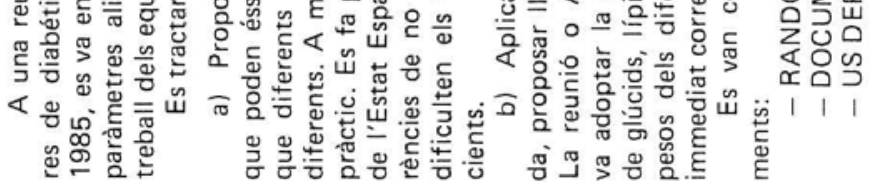




\section{ANNEX 13}

TiII Generalitat de Catalunya

Departament de Sanitat

i Seguretat Social

Direcció General d'Ordenació

i Planificació Sanitària

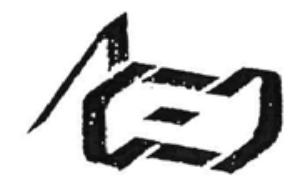

ASS. CATALANA d'EDUCADORS EN DIABETiS SECCIÓ DE DIABETIS - HOSPITAL CUINIC

Carrer Cosenoves, 143

O8036 BARCELONA

Benvolguts companys,

Com recordareu, a l'igual que el mes de novembre passat, dins del Curs de Formació de Professorat en Educació Diabetològica, organitzat pel Consell Assessor sobre la Diabetis a Catalunya, Institut d'Estudis de la Salut, Departament de Sanitat i Seguretat Social de la Generalitat, s'ha convidat al Professor Maurizio Mori per que coordini el 6è. stage.

Aprofitem l'avinentesa per realitzar, juntament amb l'Associació d'Educadors en Diabetis, una conferència extraordinària que versarà sobre "Formació te ?rofessionals", la qual tindrà lloc el dia 5 de març a les 19h. al Departament de Sanitat i Seguretat Social, Travessera de les Corts, 131, (Sala d'Actes).

En Maurizio Mori es professor de Salut Comunitària de l'Istituto d'Igiene e Medecina Preventiva i del "Centro Sperimentale per l'Educazione Sanitaria de 1 'Università degli Studi di Perugia" (Centre pilot en Educació Sanitària de l'Organització Mundial de la Salut "OMS" i de la Unió Internacional d'Educació Sanitària "UIES".

Ens plau de convidar-vos a l'esmentada reunió, tot esperant la vostra assis tència.

Us saluda ben cordialment,
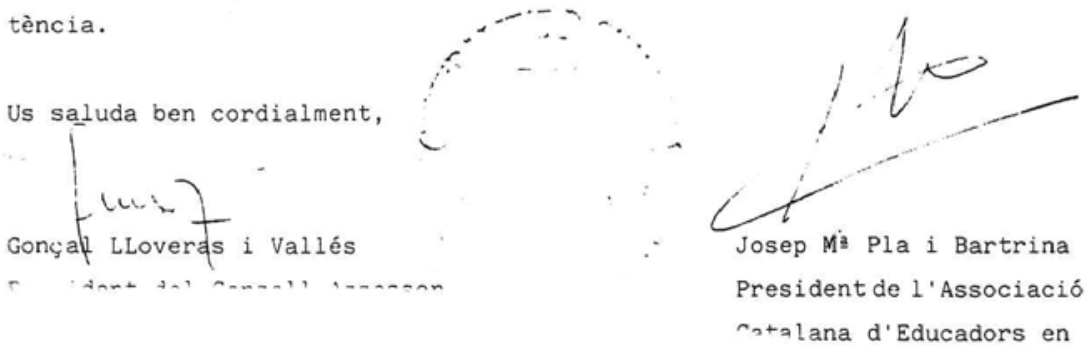


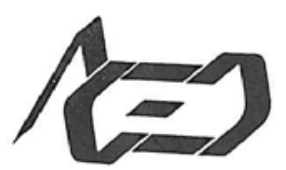

ASS. CATALANA D'EDUCADORS EN DIABETIS

\section{LA PERSUASIÓ: UN PROBLEMA D'ÈTICA?}

Resúm de la comunicació feta per

Mme. Anne Lacroix

2-Febrer-1991

Definició del verb persuadir: "Conduir a algú a creure, a pensar, a volguer, a fer alguna cosa amb una voluntat complerta, sentimental aixi com intelectual". La qüestió que es pot posar als educadors en el camp de la salut seria: algú té dret a persuadir, és moralment just fer-ho?.

El problema forma part del debat que es té en el si de les comissions d'ètica mèdica. No es pot pas dictar una llei al respecte, tan sols fer algunes recomanacions. Actualment hi han dos gran recomanacions de base.

1.- Informar al pacient formar part de l'acte mèdic, que sàpiga el diagnòstic, el tractament terapèutic 0 preventiu.

2. - Cada pacient ha de ser considerat com un interlocutor de igual a igual.

Aquestes dues recomanacions no mencionen pas com es deu o com es pot utilitzar la persuasió envers els pacients.

El problema de la persuasió l'abordanen de tres maneres:

Com els sanitaris/educadors funcionen amb els pacients portadors d'una malaltia crónica.

El model médic en general ve marcat pel de la medicina d'urgència $i$ de les malalties agudes, on els resultats són espectaculars. És dificil $i$ ingrat per als sanitaris de enfrontar-se $i$ tractar les malalties cròniques. La seva actitud oscilla entre un paternalisme $i$ atencions a vegades ecsessiu, o bé al desànim. Tenen la tentació de recòrrer a la persuasió per vèncer el seu sentiment d'impotència, no obstant cal distingir entre la persuasió positiva i la persuasió negativa.

La persuasió positiva consisteix en coratjar al pacient, mentre que la persuasió negativa utilitza la por (per ejemple les complicacions).

Els diabètics i la observància del tractament.

És menys dificil per un pacient adquirir coneixement sobre la seva malaltia que no pas consentir els canvis que signifiquin: Ex. posarse les injeccions, renunciar a fumar o modificar els hàbits de vida. És més facil tractar una afectació visible que no pas una malaltia invisible com és la diabetis, a més a més per aconseguir l'acceptació d'una malaltia que no es curarà cal renunciar al seu estat de salut anterior. L'esforç d'aquesta renuncia és un procés al llarg del qual reconeixem algunes etapes caracteristiques. Donem dos exemples: La negació, quan el pacient es comporta com si no tingues en realitat cap malaltia i la rebeldia, que observem molt 


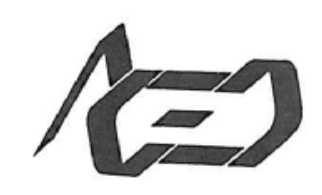

ASS. CATALANA D’EDUCADORS EN DIABETIS

frequentment en els adolescents diabètics. En aquestes dues situacions, els pacients estant totalment refrectaris a la persuasió.

El punt de vista de la psicologia.

ouan un sanitari o un educador tracta de convèncer els pacients, es dirigeix al "super-ego" (a instancies de la part més represiva de la personalitat) i el malalt ho reb com un judici moral. Val més negociar amb el pacient els canvis que és capaç d'acceptar $i$ que seran a la vegada realitzables. Cal respectar el ritme i les capacitats del pacient, aixó exigeix per part dels sanitaris molt de suport, de convenciment i de paciència.

La persuasió corre el risc en el millor dels casos, de ser un error en la psicologia. 


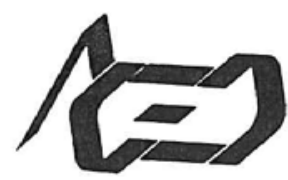

\title{
ASS. CATALANA D’EDUCADORS EN DIABETIS
}

SECCIÓ DE DIABETIS - HOSPITAL CLINIC

Carrer Casanovas, 143

08036 BARCELONA

\section{PREMI DE L'ASSOCIACIÓ CATALANA}

\author{
D'EDUCADORS EN DIABETIS
}

Es convoca a la presentació de treballs per aspirar al I Premi de l'Associació Catalana d'Educadors en Diabetis. Aquest premi, s'atorgarà d'acord amb les següents bases:

ler. Podran optar-hi tots aquells professionals que, exerceixin la seva tasca d'atenció al pacient diabètic, en qualsevol dels seus aspectes, dins de l'àmbit territorial de Catalunya.

2on. Els treballs versaràn sobre la Diabetis, remarcant prioritàriament els aspectes educatius.

3er. El treball s'haurà de presentar escrit a màquina, a doble espai, en una extensió no superior a 15 folis. Podrà anar acompanyat de tota la documentació gràfica que calgui. S'entregarà a la secció de diabetis de l'Hospital Clinic de Barcelona (c/Casanovas, 143 - 08036 Barcelona).

4 at. Per tal de mantenir l'anonimat dels treballs, aquests es presentaran sense firmar, dins un sobre tancat (tamany foli) amb un lema, acompanyats d'un segon sobre més petit (tamany carta), també tancat $i$ amb el mateix lema, dins el segon sobre hi constarà: el nom i cognoms del autor/s, l'adreça, si és metge, infermera, dietista,..... i el lloc on desenvolupa/n la tasca educativa i d'atenció al diabètic.

5è. El plaç de presentació dels treballs finalitzarà el dia 31. d'Octubre de 1989 a les $12 \mathrm{~h}$.

6è. Es valorarà com a mèrit preferent, aquell treball que presenti una experiència en educació diabetològica i que el seu contingut pugui ser d'utilitat per millorar l'atenció al malalt diabètic (per davant dels treballs que presentin un projecte).

7è. El Premi es concedirà per votació entre els membres d'un jurat constituit per les persones següents: Presicient del Consell Assessor sobre la diabetis a Catalunya; President de la Societat Catalana d'Educadors en Diabetis; President de la Societat Catalana de Diabetis; dos membres de la Junta de I'A.C.d'E.D.

8è. Els membres de la Junta de l'Associació, així com els membres del Jurat, s'abstindràn de presentar cap treball.

9è. El Premi, dotat en 150.000 Ptes., serà lliurat en ei transcurs de la V Reunió Anual de l'Associació, que enguany tindrà $110 \mathrm{c}$ el dia 16 de Desembre a Igualada.

10è. L'autor premiat es compromet a presentar el trebali en l'esmentada Reunió. 


\section{ANNEX 16 A}

JUDIT RODERGAS i PAGES , infermera col.legiada no 8755 , presidenta de l'Associació Catalana d'Educadors en diabetis,

A V.A L 0

el treball amb el títol de Passat, present i futur de l'educació diabetològica al sector de Terrassa,

realitzat per: Sánchez Garcia, A.; Valverde Torreguitart, M.T., Viladot Aguayo, A., Riera Garcia, M. i Esquius Carbonell, E., educadores en dia betis.

Considero que aquest treball posa de manifest la important tasca docent $i$ assistencial de l'equip, a la vegada que és de gran interés en l'educació sanitària i diabetològica.

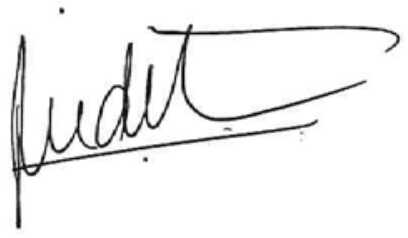

Judit Rodergas i Pages

Presidenta de l'Associació Catalana d'Educadors en diabetis

Terrassa, 27 de febrer de 1990. 
Generalitat de Catalunya

Departament de Sanitat i Seguretat Social

\section{Direcció General de Salut Pública}

Travessera de les Corts, 131.159

Pavelló Ave Maria

08028 Barcelona

Telèfon (93) 3391111

Télex 54205.DSSSe

Fax (93) 4111114

CONSELL ASSESSOR SOBRE LA DIABETIS A CATALUNYA

GONCAL LLOVERAS i VALLES, com a President del Consell Assessor sobre 1a Diabetis a Catalunya del Departament de Sanitat de la Generalitat de Catalunya

F A I G C O N S T A R,

Que el treball " PASSAT, PRESENT i FUTUR DE L 'EDUCACIÓ DIABETO LÓGICA AL SECTOR DE TERRASA", realitzat per les Sres. Anna Sànchez, Ma Teresa Valverde, Anna Viladot, Montserrat Riera i Eulàlia Esquius, educadores en Diabetis d'aquest sector, és d’alta qualitat $i$ rigor tècnic, i d'especial interès per la sistematització de la metodologia educativa en Diabetis

I per a que aixi consti i a efectes de les interessades, signo la present certificació a, Barcelona vint-i-sis de febrer de mil nou-cents noranta

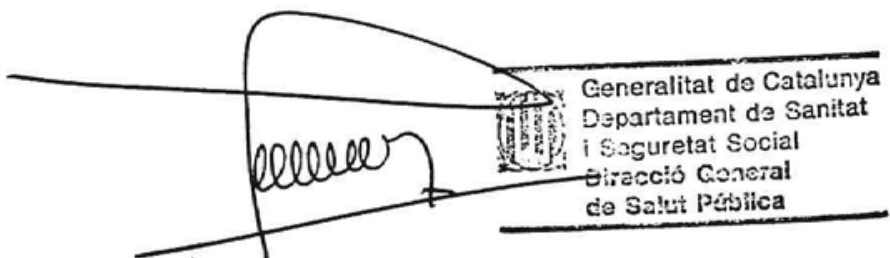


Institut Català de la Salut
Àrea de Gestió 7, Centre

Torrebonica $8 / \mathrm{n}$

08227 Terrassa

Telèfon (93) 7862412

ESTEBAN CARRILlO RIDAO, metge, cap de la Secció de Qualitat Assistencial de l'Ảrea de Gestió 7, Centre,

A V A L O

el treball amb el titol de Passat, present $i$ futur de l'educació diabetològica al sector de Terrassa,

realitzat per: Sánchez Garcia, A.; Valverde Torreguitart, M.T.; Viladot Aguayo, A., Riera Garcia, M. i Esquius Carbonell, E., educadores en diabetis.

Aquest treball considero que aporta una millora a l'atenció integral del diabètic, $i$ que augmenta aixi la seva qualitat de vida.
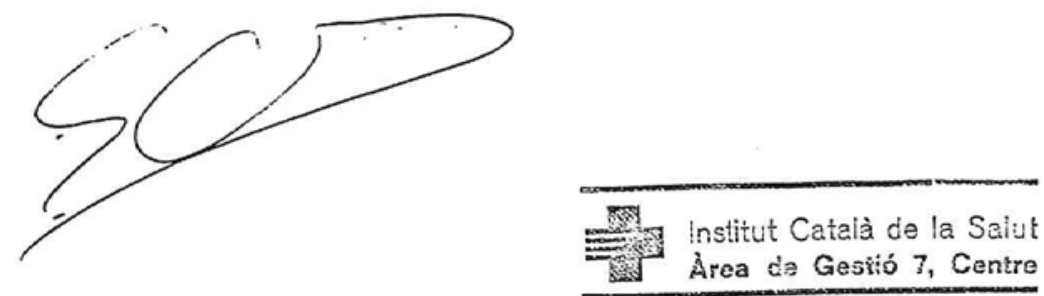

Esteban Carrillo Ridao

Cap de la Secció de Qualitat Assistencial

Terrassa, 27 de febrer de 1990. 


\section{ANNEX 16 B}

\section{PASSAT, PRESENT I FUTUR \\ DE L'EDUCACIó DIABETOLòGICA \\ AL SECTOR DE TERRASSA}

Educadores: A.SANCHEZ, M.T VALVERDE, A.VILADOT, M.RIERA, E.ESQUIUS. 


\section{INTRODUCCIO}

El creixent interés per la malaltia neix del convenciment cada vegada més generalitzat a la societat, de que els coneixements sobre la salut i la malaltia són un dret de tots i no el patrimoni d'uns quants professionals.

L'educació sanitària en cas de la diabetis és rigurosament ineludible, forma part del seu tractament. La importància de 1 'educació diabetológica és deguada a que la diabetis melitus és en primer lloc, una malaltia crónica, sempre incurable. Això vol dir que el pacient haurà d'aceptar aquesta realitat $i$ aprendre a conviure-hi. No pot sentir-se indiferent, ni viure angoixat, vol dir, en definitiva, asegurar-se la qualitat de vida present i futura evitant, endarrerint 0 atenuant les complicacions que la malaltia comporta.

L'accés a la informacio entre els diabètics no és només un dret, si no també una necessitat de manera que quan s'aconsegueix una educació adequada el risc es redueix, la qualitat de vida millora $i$ n'esdevé per tant un benefici social i económic.

Entre els molts estudis que demostren aquestes ressenyes a Los Angeles es va desenvolupar, durant dos anys, un ampli programa d'ensenyament als malalts, demostrant al finalitzar el mateix una disminució en la incidencia de la hospitalització de 5.7 dies/any à 1.4 dies/any (en la població no diabètica, el mateix index era de 1.2 i no es va modificar durant 1 'estudi). 
En la població danesa es va demostrar una supervivència més perllongada (entre 5 i 10 anys) entre els diabetics adequadament controlats $i$ ensinistrats quan van esser comparats amb un altre grup que no complia aquestes condicions.

A l'Hospital Cantonal de Ginebra es va xifrar en més d'un milio de francs suïssos 1 'estalvi obtingut en un any mitjançant 1'educació de tota la població diabètica sobre la prevenció de lesions en els peus.

Per manca encara de resultats d'estudis epidemiologics de la població diabètica a Catalunya, actualment en curs, ens veiem obligats a utilitzar dades d'altres païssos occidentals, on la prevalença es calcula al voltant del $3 \%$ per la diabetis en general, $i$ del $0.3 \%$, especificament per la forma juvenil. Si considerem el cens a Catalunya 1'any 1980 que era de 5.900.000 persones, probablement 177.000 (3\%) son diabètiques i 17.700 tindrien una diabetis juvenil o de tipus $I$.

El sector d'actuació del nostre grup afecta majoritàriament a tres poblacions, Terrassa, Rubí $i$ Sant Cugat amb un cens aproximat de 250.000 persones de les quals serien diabètiques entre 7.000 i 8.000 i de 700 a 800 portadores d'una diabetis tipus I.

Convençuts de que els professionals d'infermeria erem $i$ som el col.lectiu 'més implicat en 1'assistència del diabètic, ja sigui per detectar ràpidament les seves necessitats físiques, socials i familiars, o bé per la proximació i temps vàrem iniciar a 1 'Hospital Mútua de Terrassa, l'any 1986, un programa 
d'educació a pacients diabètics que ha estat modificat en el curs del temps en funció dels resultats. Les diferències de plantejament, metodologia $i$ avaluacio obeiexen al nostre propi aprenentatge, de forma que el programa inicial ens ha portat a realitzar un segon programa en funcio dels resultats prèviament obtinguts.

\section{PRIMER PROGRAMA O PROGRAMA INICIAL (1986-1988).}

OBJECTIUS A CURT TERMINI:

Realitzar un programa d'ensenyament que augmenti els coneixements dels diabetics per tal de:

* Transmentre coneixements sobre la malaltia aixi com les noves perspectives de futur.

* Apendre les bases fonamentals del tractament mèdic i dietètic.

* Aconseguir un òptim autocontrol de la malaltia.

A ixò ens portaria uns objectius generals:

* Aconseguir més independència del diabètic.

* Disminuir les hospítalitzacions i complicacions.

* En resum: millorar la qualitat de vida.

DESENVOLUPAMENT DEL PROGRAMA:

Es va realitzar un programa únic, en el que es tenia en compte els coneixements previs dels malalts ingressats, establint-se un primer nivell bàsic. 
No ens vàrem plantejar fer diferents grups (edat, tipus de coneixements, etc...) per la dificultat que ens comportava, degut, en gran part, als escassos dies d'estada i a la heterogeneitat del grup.

\section{PLANIFICACIÓ:}

S'establiren tres dies de classe a la setmana (dilluns, dimecres i divendres), separant el contingut del programa en tres blocs independents a fi de que es poguessin beneficiar del mateix el major nombre de persones (veure annexes 1,2 i 3 amb el desglosament dels objectius generals i especifics).

A cada malalt se li va fer una fitxa tècnica on constaven les següents dades:

- Tipus de diabetis.

- Tractament.

- Temps d'evolució.

- Complicacions.

- Estudis.

- Observacions.

- Reingressos.

- Evaluacions.

\section{METODOLOGIA :}

Les sessions es realitzaren amb una metodologia activa, mitjançant experiencies personals, estudi i presentació de casos. 


\section{AVALUACIO:}

Es va realitzar fonamentalment una avaluació escrita mitjançant un test de coneixements (modificació del TCD-M2) abans i després de cada curs, d'aplicació individual i que constava de set preguntes d'elecció múltiple per sessio, amb un índex de dificultat molt baix, basades en conceptes fonamentals i escrit en castellà. Per exemple:

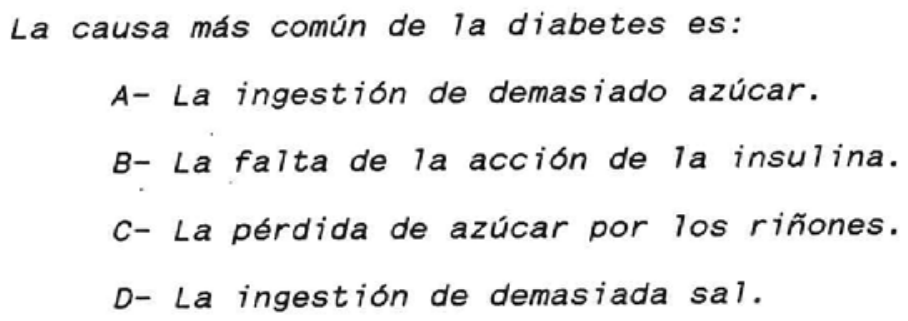


ANNEXE 1

OBJECTIUS GENERALS:

1- Conèixer què és la diabetis melitus.

2- Concienciar de la necessitat d'instrucció en educació diabetològica.

3- Apendre les bases elementals del tractament.

4- Transmetre les perspectives de futur.

OBJECTIUS ESPECíFICS:

1- Coneixer què és la diabetis melitus.

- definir què és 1a DM

- informar de la incidencia

- descriure el tipus de diabetis

- analitzar l'acció de la insulina i dels aliments

2- Concienciar de la necessitat d'instrucció.

- optimitzar el control

- prevenir les complicacions

3- Apendre les bases elementals del tractament.

- justificar la necessitat de la dieta

- demostrar 1 'efecte dels fàrmacs (hipoglicemiants, insulina)

- interpretar l'acció de l'exercici

4- Transmetre les perspectives de futur.

- explicar noves vies i tecniques d'admisnistració d'insulina

- prevenir la malaltia. 
ANNEXE 2

OBJECTIUS GENERALS

1- Concienciar de la importancia de 1'autocontrol.

2- Explicar la tècnica de l'injecció.

3- Entendre el concepte d'hipoglicèmia.

\section{OBJECTIUS ESPECÍFICS}

1- Concienciar de la importancia de l'autocontrol.

- assumir la necessitat del control

- discriminar entre els diferents mètodes

- detectar situacions de risc

2- Explicar la tècnica de l'injecció.

- punxar-se correctament

3- Entendre el concepte d'hipoglicèmia.

- identificar la causa

- conèixer els símptomes

- deduir-ne el tractament 
ANNEXE 3

OBJECTIUS GENERALS:

1- Concienciar de la importancia de la dieta.

2- Valorar l'efecte de l'exercici.

3- Pendre conciencia de les complicacions de la DM.

OBJECTIUS ESPECÍFICS:

1- Concienciar de la importancia de la dieta.

- classificar els aliments per grups

- separar-ne els que requereixen control de pes i horari

- determinar una dieta equilibrada

2- Valorar l'efecte de l'exercici.

- analitzar els tipus d'exercici més adequats per diabètics

3- Pendre conciència de les complicacions de la DM.

- informar com prevenir les complicacions

- cura dels peus 

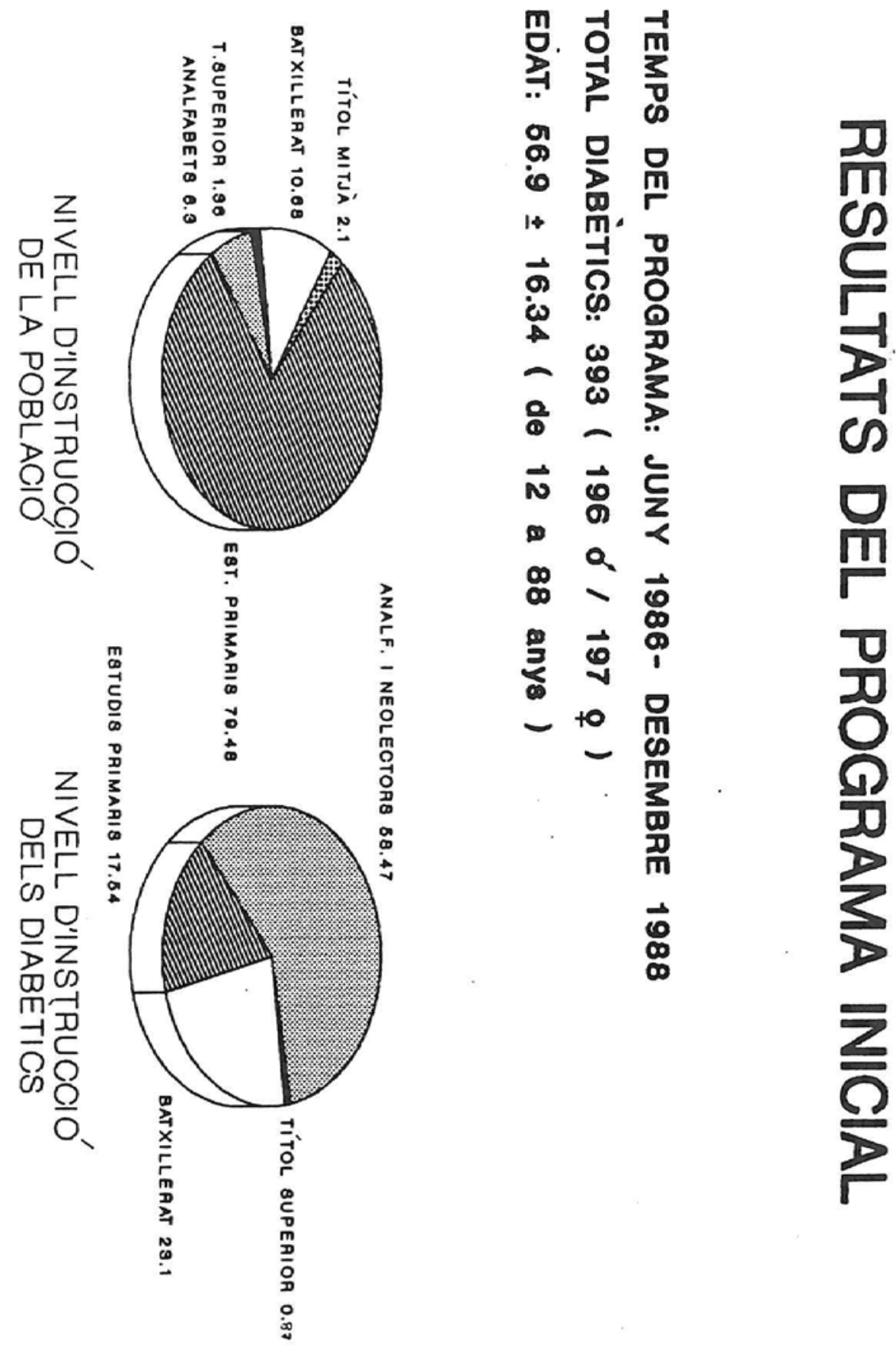

N $\overrightarrow{0} \frac{E}{2}$

$\infty$ a

$\square$

II

晃

— +

20

-

$\infty$
$\mathbf{m}$
$\mathbf{m}$
$\mathbf{m}$
$\mathbf{m}$
$\mathbf{0}$
$\mathbf{\infty}$
$\mathbf{\infty}$
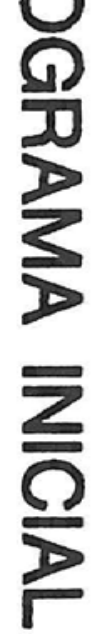

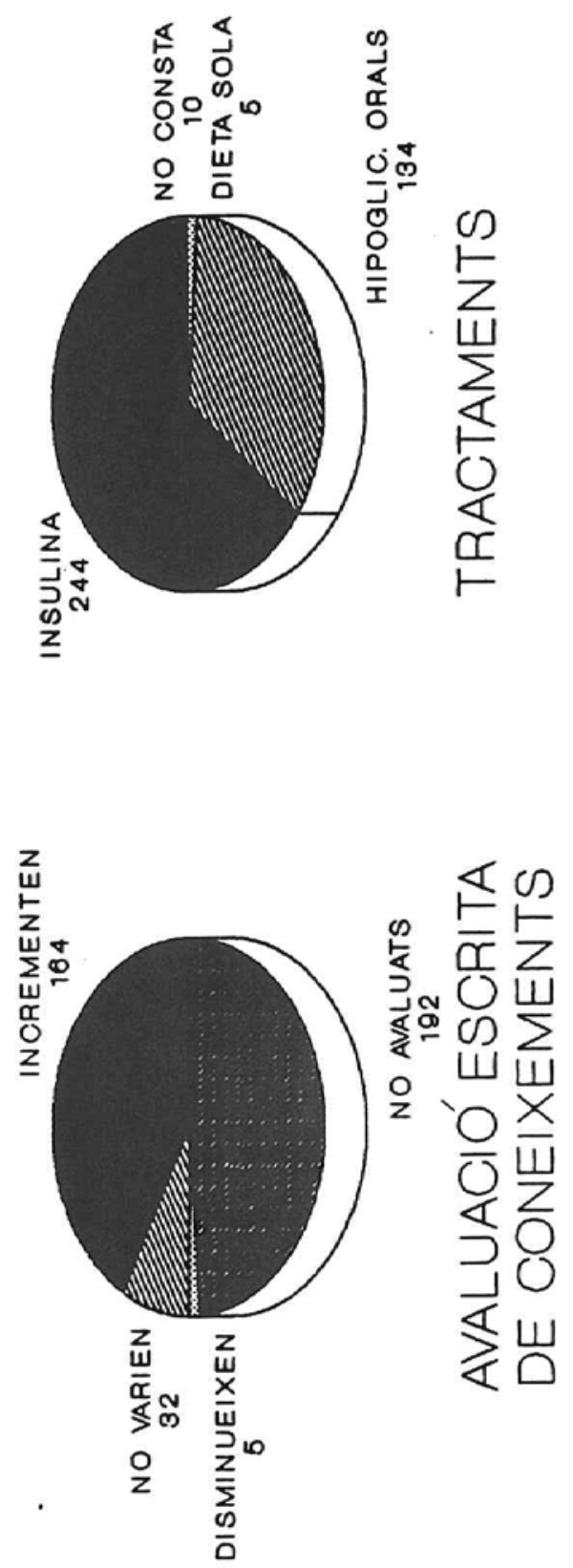
En resum doncs aquest programa inicial es va realitzar entre Juny de 1986 i Desembre de 1988 en un total de 393 diabètics, 196 homes $i 197$ dones, amb una edat mitja de $56.9 \pm 16.34$ (12-88). D'aquest total de diabètics es va poder realitzar l'avaluació escrita previa només en 201 pacients, éssent impossible practicar-la en els 192 restants per tractar-se de malalts analfabets totals o funcionals (gràfic 1.A)

Dels pacients que es va poder realitzar l'avaluació escrita 164 van incrementar els coneixements al final del programa, en 32 el nivell de coneixements fou similar i 5 diabètics els van disminuir probablement degut a 1 'atzar (gràfic 1.B)

Aquestes dades van motivar un replantejament de la nostra línea de treball, al trobar que un gran sector de poblacio diabètica, o bé cronologicament havia entrat ja en un període maduratiu propi de la vellesa, o bé a conseqüencia de la seva malaltia, havia entrat en un deteriorament progressiu anticipat a les seves funcions biologiques, així com de les seves capacitats psíquiques $i$ intel.lectuals, amb les complicacions socio-economiques que el procés comporta.

Totes aquestes 7 imitacions $i$ restriccions que la diabetis els imposa, determinen el seu estat de vida. Aconseguir millorar el seu nivell'de qualitat de vida (incidint en els aspectes biologics, sociologics $i$ psicologics), va ser la finalitat del grup d'educadors pel que vem dissenyar el segon programa. 


\section{SEGON PROGRAMA (1988-1990)}

\section{DEFINICIO DE NIVELLS}

S'han dissenyat 3 subprogrames amb les següents característiques $i$ d'acord amb l'estudi poblacional realitzat.

NIVELL I: - Diabètics insulinotractats $i$ no insulinotractats.

- Sense o pocs coneixements sobre la diabetis.

- Amb limitacions per a 1'aprenentatge: físiques (visi6, sordera,...); intel.lectuals (analfabetisme, senilitat).

NIVELL II:- Diabètics insulinotractats $i$ no insulinotractats Sense o pocs coneixements sobre la diabetis Amb capacitat bàsica per a l'aprenentatge.

NIVELL III:-Diabetics insulinotractats i no insulinotractats. Amb coneixements previs sobre la diabetis. Amb un nivell cultural mig/elevat.

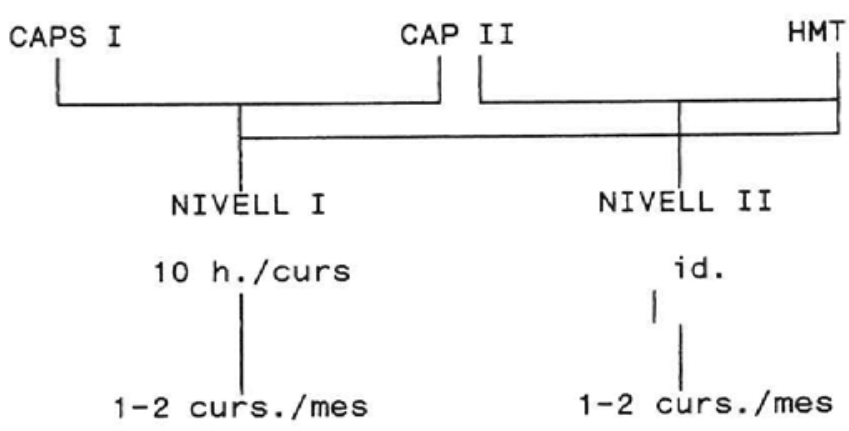

PER DEFINIR

2 stage de cap de setmana segons requeriments. 


\begin{tabular}{|c|c|c|c|}
\hline $\begin{array}{l}\text { NIVELLS DE DIFICULTAT D'OBJECTIUS } \\
\text { I CONTINGUTS }\end{array}$ & $N I$ & NII & NIII \\
\hline 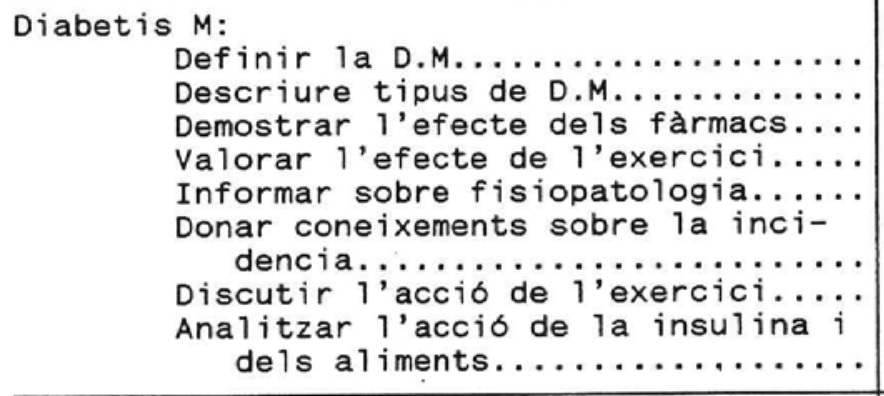 & & $\begin{array}{l}* \\
* \\
* \\
*\end{array}$ & $\begin{array}{l}* \\
* \\
* \\
* \\
* \\
* \\
* \\
*\end{array}$ \\
\hline 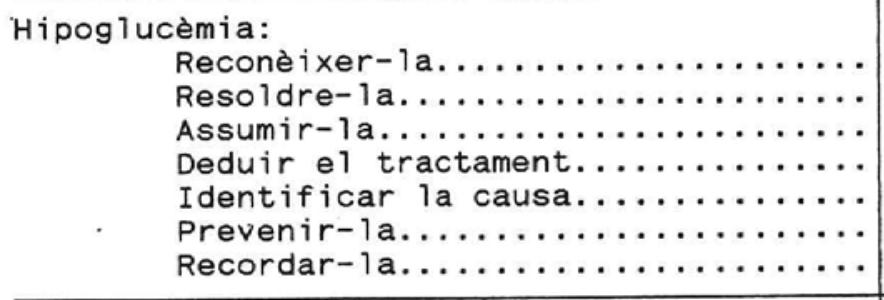 & $\begin{array}{l}* \\
* \\
*\end{array}$ & $\begin{array}{l}* \\
* \\
*\end{array}$ & $*$ \\
\hline 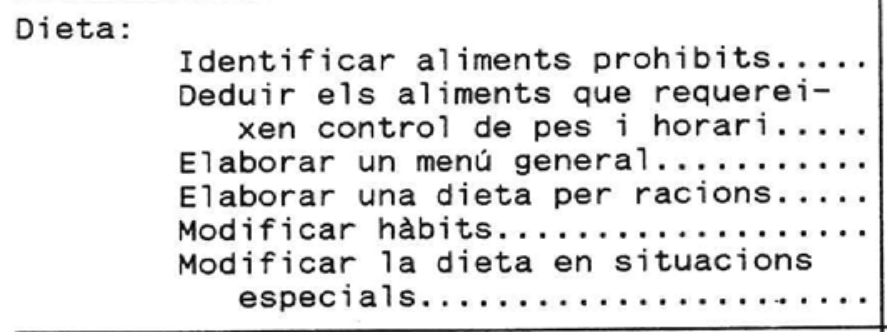 & * & $\begin{array}{l}* \\
* \\
* \\
*\end{array}$ & * \\
\hline 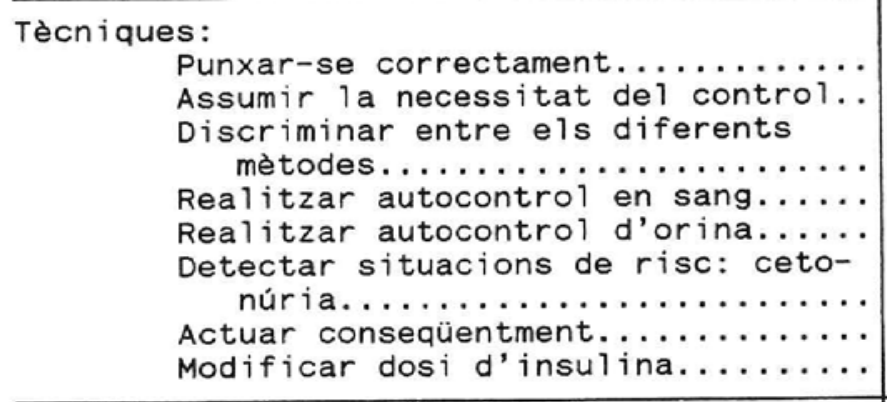 & $*$ & $\begin{array}{l}* \\
* \\
* \\
* \\
* \\
*\end{array}$ & $\begin{array}{l}* \\
*\end{array}$ \\
\hline $\begin{array}{l}\text { Complicacions: } \\
\text { Aprendre la higiene............... } \\
\text { Utilitzar correctament e i material. } \\
\text { Actuar davant les ferides......... } \\
\text { Descriminar instruments prohibits.. } \\
\text { Informar com prevenir les complic.. }\end{array}$ & $\begin{array}{l}* \\
* \\
* \\
*\end{array}$ & $*$ & $*$ \\
\hline
\end{tabular}




\begin{tabular}{|c|c|c|c|}
\hline $\begin{array}{l}\text { NIVELLS DE DIFICULTATS D'OBJECTIUS } \\
\text { I CONTINGUTS }\end{array}$ & $N I$ & NI I & NII I \\
\hline 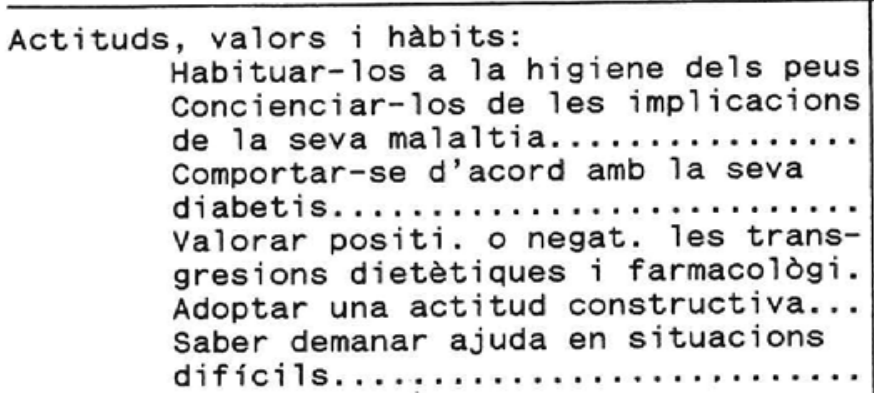 & * & * & $\begin{array}{l}* \\
* \\
* \\
* \\
*\end{array}$ \\
\hline
\end{tabular}

El fet de pertanyer al nivell II o nivell III implica haver assumit els contiguts $i$ objectius del nivell anterior.

Considerem que la manera més adequada d'impartir 1 'ensenyament per tal d'aconseguir els continguts $i$ objectius es basa en adaptar els metodes d'aprenentatge a les característiques individuals dels alumnes $i$ el seu nivell corresponent.

En el moment actual ens queda per portar a termini la realització del subprograma de nivell III així com els reciclatges dels nivells I $i$ II.

A continuacio s'exposen algunes activitats assenyalant el nivel1 pel qual es consideren més idoni.

\begin{tabular}{|c|c|c|c|}
\hline ACTIVITATS & NI & NII & NI I I \\
\hline 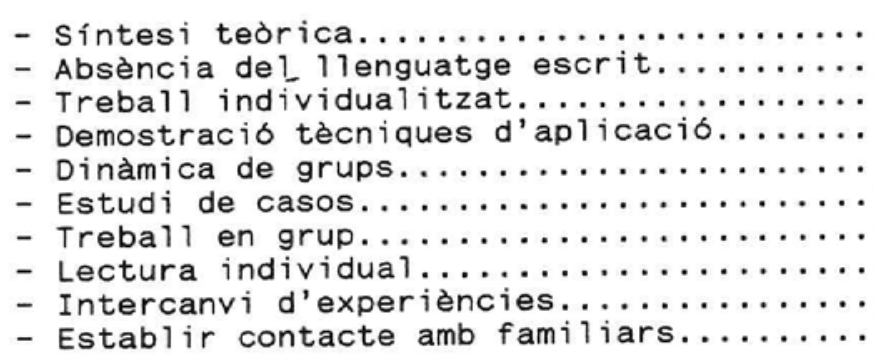 & $\begin{array}{l}* \\
* \\
*\end{array}$ & $\begin{array}{l}* \\
* \\
* \\
*\end{array}$ & $\begin{array}{l}* \\
* \\
* \\
* \\
* \\
* \\
* \\
* \\
* \\
*\end{array}$ \\
\hline
\end{tabular}


AVALUACIO

\begin{tabular}{|c|c|c|}
\hline VALUACIO INICIAL & A. DEL PROCÉS & AVALUACIO FINAL \\
\hline $\begin{array}{l}\text { Els coneixements } \\
\text { i les actituds } \\
\text { que tenen els } \\
\text { diabetics abans } \\
\text { d'iniciar e l } \\
\text { programa d'apre- } \\
\text { nentatge. }\end{array}$ & $\begin{array}{l}\text { Els progressos i } \\
\text { les dificultats } \\
\text { que succeieixen } \\
\text { durant el curs. }\end{array}$ & $\begin{array}{l}\text { Els continguts } \\
\text { seleccionats per } \\
\text { cada nivell aixi } \\
\text { com el canvi } \\
\text { d'actituds } \\
\text { esperat. }\end{array}$ \\
\hline $\begin{array}{l}\text { Al començament } \\
\text { d'una nova fase } \\
\text { d'ap renentatge. }\end{array}$ & $\begin{array}{l}\text { Durant el procés } \\
\text { d'aprenentatge. }\end{array}$ & $\begin{array}{l}\text { A 1'acabar una } \\
\text { fase d'apre- } \\
\text { nentatge i als } 6 \text {, } \\
12 \text { i } 24 \text { mesos. }\end{array}$ \\
\hline $\begin{array}{l}\text { Proves } \\
\text { objectives } \\
\text { (NII, III). }\end{array}$ & $\begin{array}{l}\text { Observació directa } \\
\text { d'una actuació } \\
(N \text { I) }\end{array}$ & $\begin{array}{l}\text { Proves objectives } \\
\text { (NII i III) }\end{array}$ \\
\hline $\begin{array}{l}\text { Pretest oral o } \\
\text { escrits } \\
(\mathrm{NI}, \mathrm{II}, \mathrm{III})\end{array}$ & $\begin{array}{l}\text { Preguntes obertes } \\
\text { (NI, II, III) } \\
\text { so } 1 \text { ucio de } \\
\text { problemes } \\
(\text { NII i III) }\end{array}$ & $\begin{array}{l}\text { Post-test } \\
(N I, \text { II } i \text { III })\end{array}$ \\
\hline
\end{tabular}




\section{RESULTATS PRELIMINARS}

\section{NIVELL I}

Temps de programa .......... Gener al set. del 89

Nombre de diabètics........... 86

Edat mitja.............. 65.27 (36 - 86$)$

Anys d'evolució.............. 12.08 (0 - 40)

Insulinotractats.......... 47,61\%

Lesions als peus (gràfic 2)

Grau d'independència i/o autonomia (gràfic 2)

Avaluació de coneixements (gràfic 3 )

NIVELL II

Temps de programa........... Gener al set. del 89

Nombre de diabètics............. 34 (18 h./16 d.)

Edat mitja .............. $50.5(27-66)$

Tipus I / Tipus II ......... 5 / 29

Tractaments: (gràfic 4 )

Nivell cultural:

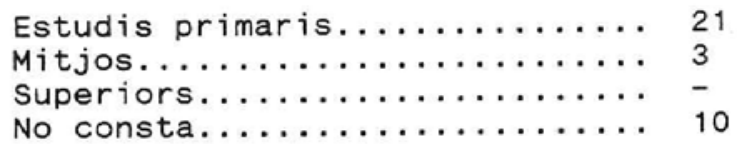

Augment de coneixements........ 23

No evaluats................. 9 

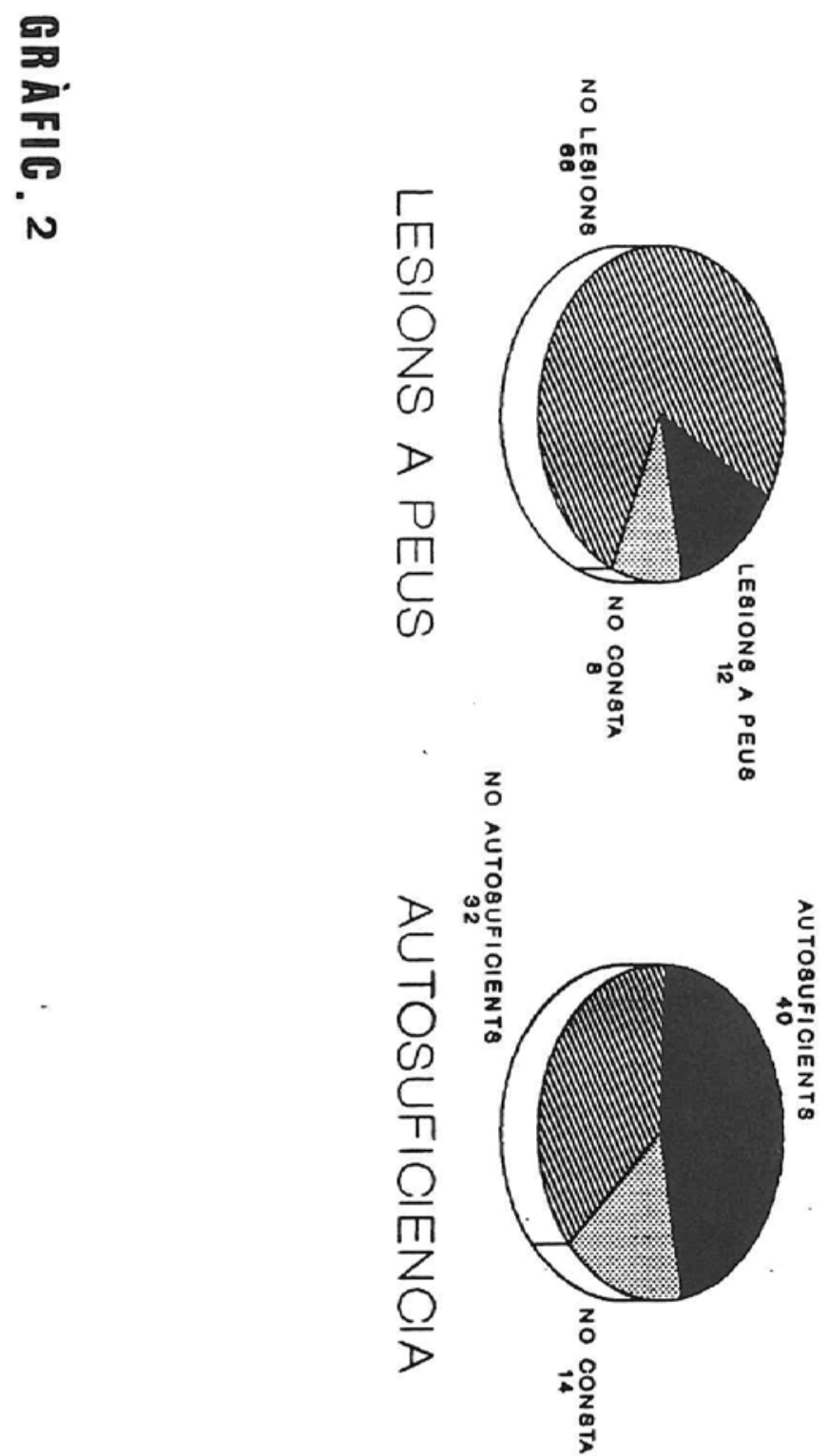


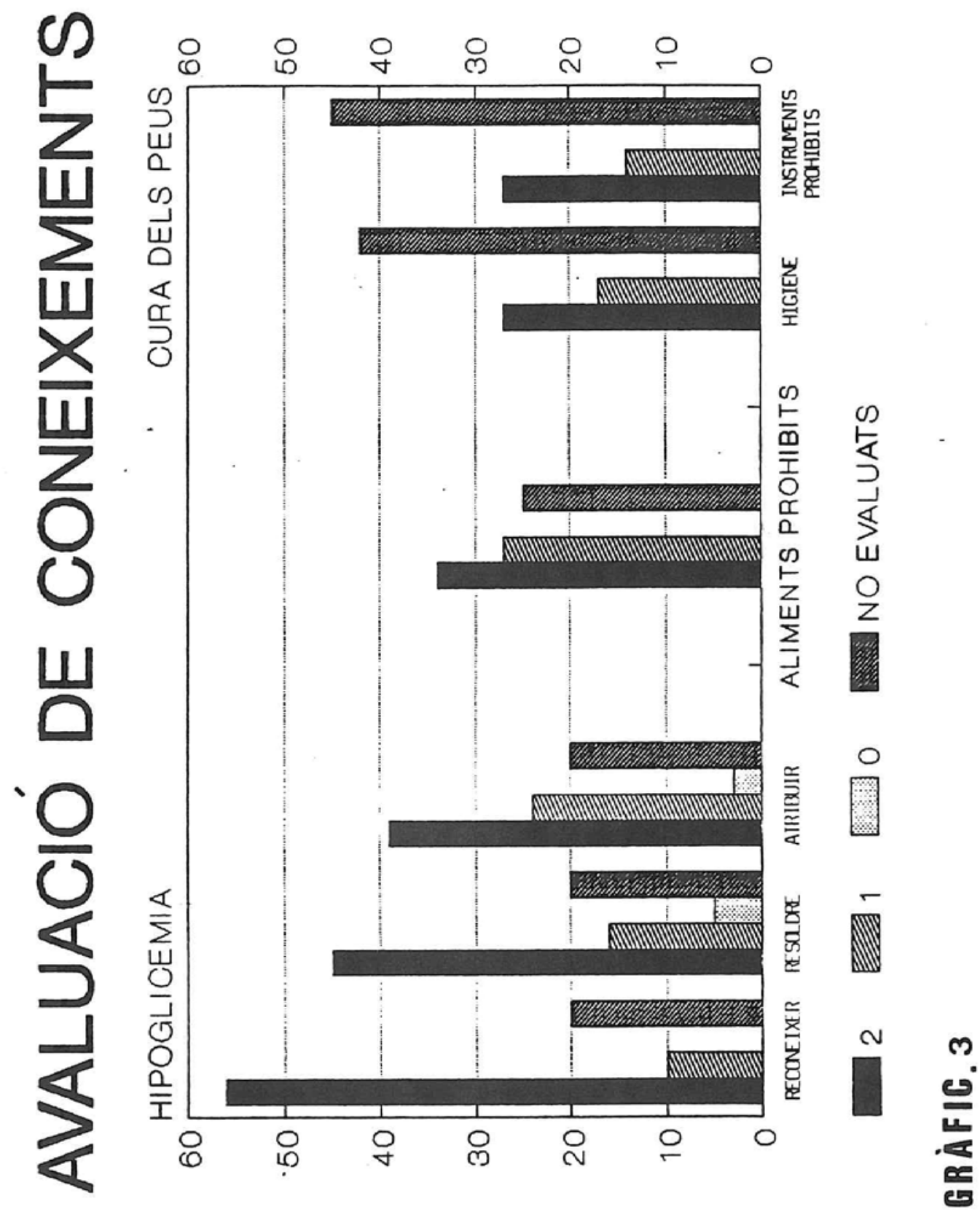



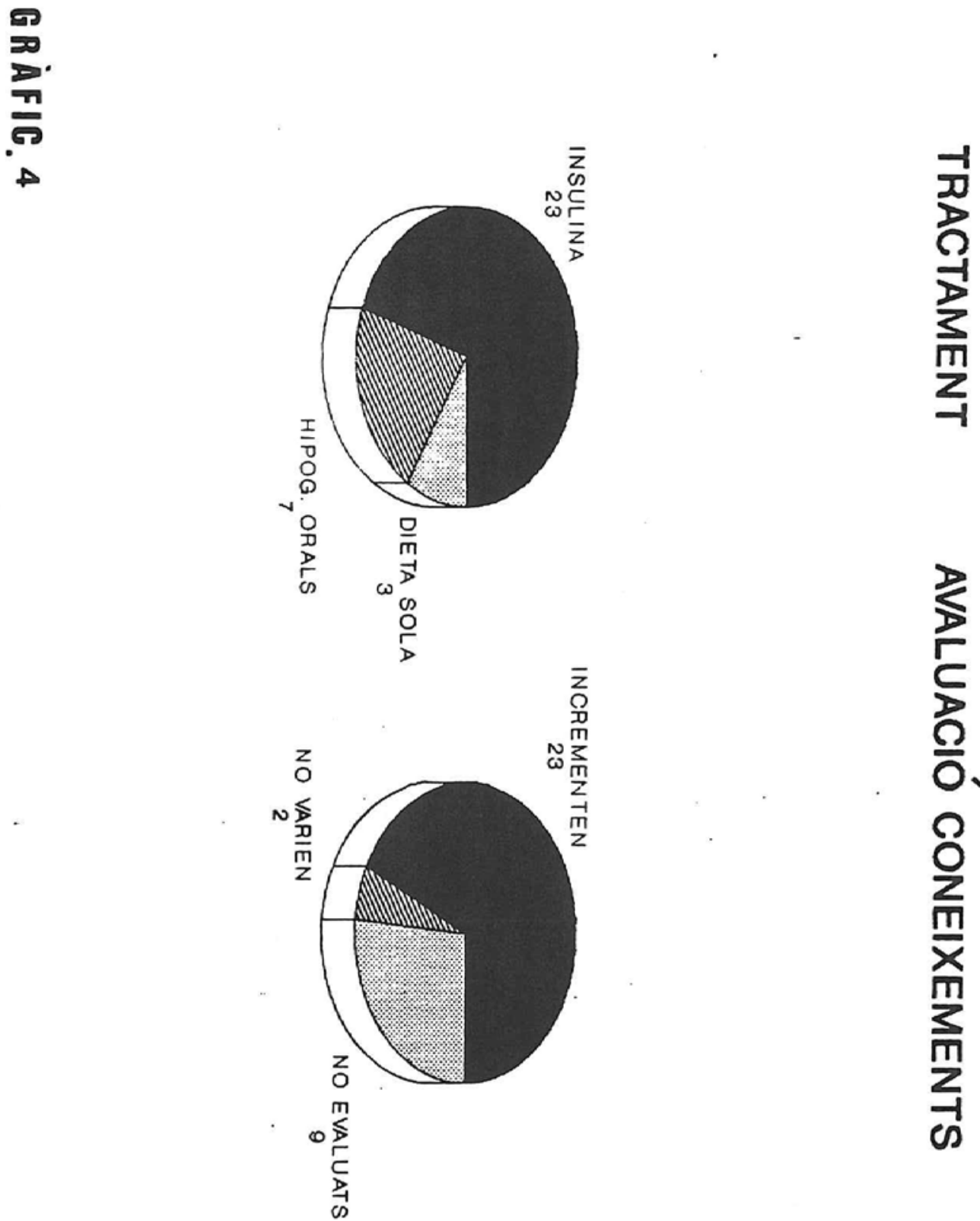


\section{CONCLUSIONS}

* La programació per nivells ha facilitat un millor aprofitament per ambdós nivells ja sigui en la vessant pràctica i/o tedrica.

* S'ha constatat més participació i il. lusió en els malalts del nivell I al no sentir-se entre el grup amb diferències físiques $i / o$ intel. lectuals.

* Malgrat 1 'avaluació del nivell I és lenta en el temps $i$ més subjectiva, ens ha permès obtenir un criteri dels coneixements adquirits.

* No podem demostrar una modificació del control metabolic ja que no es va plantejar d'inici per qüestions extra professionals que impedirien un seguiment correcte.

* És doncs imprescindible, previ a la realització d'un programa d'educació diabetologica, fer UN ESTUDI molt acurat DE LA REALITAT, per poder aixi dissenyar un programa amb objectius, continguts, activitats $i$ fins $i$ tot avaluació especific pel grup. 


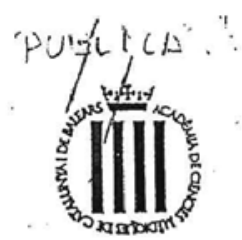

Filial del Bages

H/NDL - DE RE C. IN 9:213:1993

\title{
I CONGRÉS DE L'ASSOCIACIÓ CATALANA DE DIABETIS
}

\author{
M A N R E S A, 7 i 8 de maig de 1993
}

RESUM DE LA COMUNICACIÓ

EDUCACIÓ SANITÀRIA APLICADA A LA DIABETIS.OPINIÓ DELS PROFESIONLS
AUTORS: *C. Pereż,* J.Rodergas, $* *$ C.Castells, ** R. Treserras, ** G. Loveras

GEVIRE DE TREBAL:Ass.Catalana d'Educadors en Diabetiś. Conisell Assessor sobre la Diabetis a Catalunya

En els darrers anys, les autoritats sanitäries denostren interès per a l'atenci6 integral al diabètic (A.I.D.) (assistència més educaci6) .Des de 1983, $s$ 'han realitzat a Catalunya cursos sobre diabetis i educacio sanitäria (E.S.) per als professionals implicats;aquest fet ha influit positivament en l'assistència al diabètic, redefinint els objectius del control,provocant canvis en l'estil professional, encoratjant la consolidacío d'equips de treball i el desenvolupament de programes d'A.I.D..L'Associací Catalana d'Educadors en Diabetis anb la col.laboracio del Consell Assessor sobre la Diabetisa Catalunya, hen realitzat un sondeig d'opinio en una mostra ampliament representativa dels professionals sanitaris,treballadors de la sanitat páblica,que atenen pacients diabètics, anb els següents

QBJECTIUS: 1. Efecte i iajmplicacio dels professionals.Apreciacio subjectiva de si es realitza o no educacio diabetolögica.

2. Grau d'implantació en els centres

3. Qui educa prioritariament

4. Formaci6 especifica dels educadors.

METOOE: Es varen adreçar enquestes de 7 preguntes amb respostes tancades a:Arees Bàsiques de Salut (A.B.S.) (90).Hbspitals páblics (30).C.A.P.II anb consulta d'Endocrinologia(40). Alumes que han participat en els cursos d'Educacio Sanitaria aplicada a la Diabetis (100) i als responsables jerànuics immediats. Total 260 punts de consulta.

RESULTATS:. S'ha assolit un alt nivell de resposta(60\%), especialment en les A.B.S.

Quasi tots els professionals (97\%) consideren que sí es fa educacio sanitaria, sense entrar

en consideracions sobre la qualitat.

.La meitat dels centres consultats (48\%) disposen d'espai físic per a les activitats

educatives

. In $96 \%$ respon que és la infermera qui ha incorporat 1 'educacio dels pacients com una de les seves tasques habituals

. Un 92.9\% dels centres on s'imparteix educacio, $s^{\prime}$ 'ofereix a tots els diabètics sigui quin sigui el seu tractament

.In $63.5 \%$ fan programes estructurats, mentre que la resta ho fan a mesura que surten els problemes

.ln $30 \%$ utilitza de forma habitual un sistema d'avaluacio

.El $67 \%$ de persones han realitzat el curs bassic de diabetis i el de perfeccionament

ConcLuSIoNS: .L'Educació Sanitària a pacients diabètics ha entrat de ple en els centres on s'atenen .No tots els centres reconeixen tenir endegat un programa estructurat i menys encara els que de forma habitual segueixen una avaluacio

. Es constata la falta de treball en equip en les activitats educatives

.La formacio $\mathrm{i}$ acreditaci6 del educador-expert en diabetis-aixi can lasseva integracio són cada vegada una necesitat més prioritària.

Mecanografiar amb la màxima qualitat gràfica el resum de la comunicació dins de l'espai requadrat.

A les primeres rinies, colllocar eltitol de la comunicació (majúscules), autors (el presentador de la comunicació subrattlat) i el Centre de trebail.

En el text, escriure de forma breu: objectius, material i mètode, resultat i conclusions.

Un Comitè de valoració seleccionarà les comunicacions rebudes i la forma de presentació.

\section{TRAMESA DE RESUMS}

L'últim

Les comunicacions (original i cinc còpies) s'enviaran a: CENTRE HOSPITALARI I CARDIOLOGIC DE MANRESA

(Sra. Fina Casals - Sra. M. Assumpta Ferrer)

Av. Bases de Manresa, 6 - 08240 MANRESA

Telèfon (93) 8732550 (Ext. 124) - Telefax (93) 8741004 


\section{ANNEX 18}

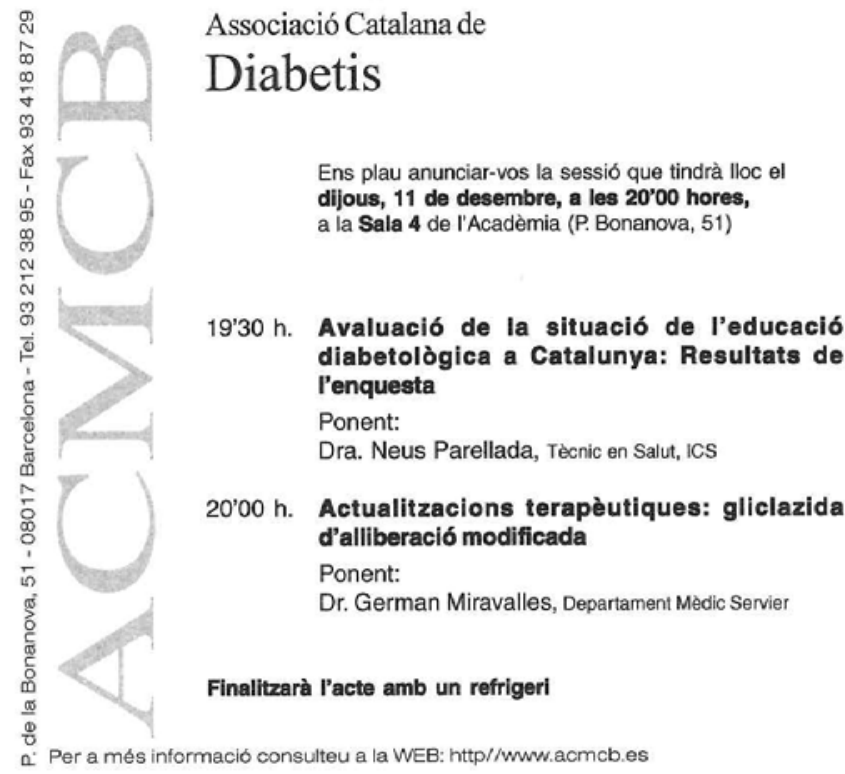

La Presidenta, Dra. N. Potau La Secretària, Dra. C. Yoldi 2003 


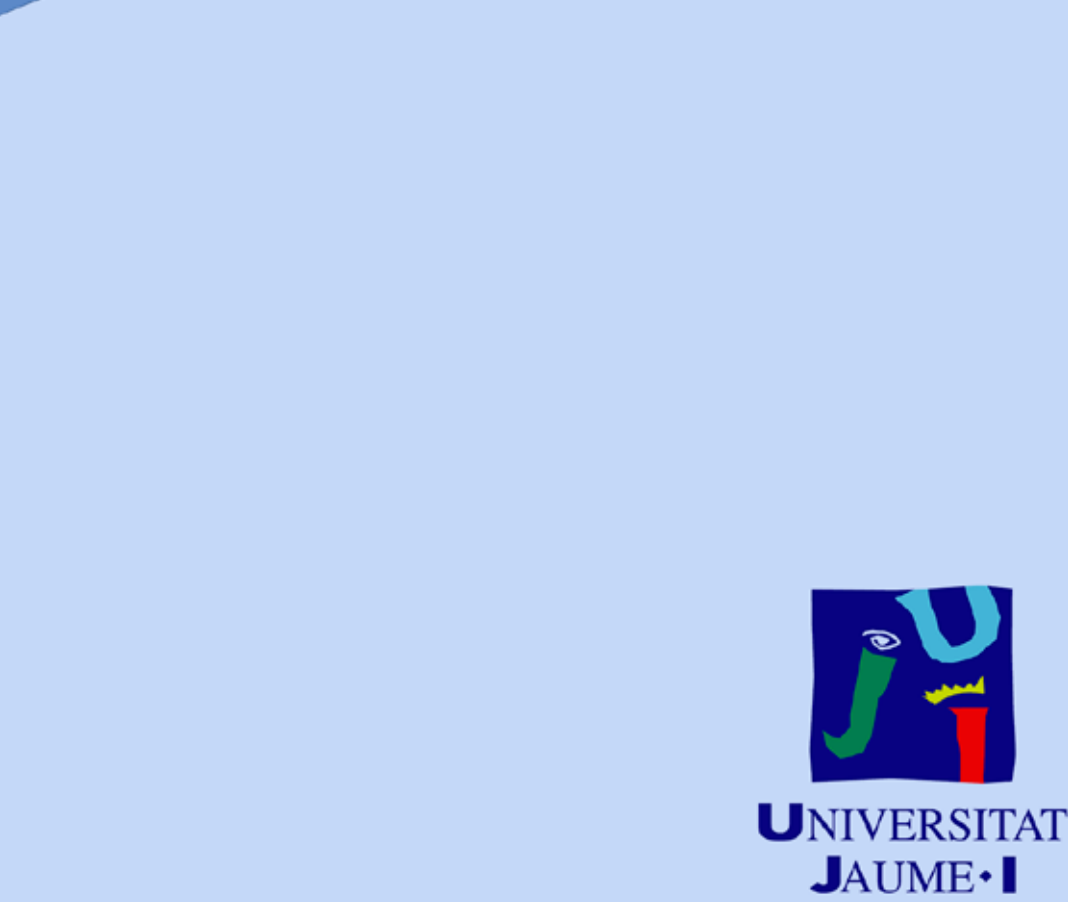

UNIVERSITAT

JAUME - I 